APLICACIÓN DE TECNOLOGÍAS SOSTENIBLES PARA EL DESARROLLO DE ALIMENTOS NUTRITIVOS Y SALUDABLES DIRIGIDOS A MEJORAR EL ESTADO NUTRICIONAL DE LA POBLACIÓN DEL DEPARTAMENTO DEL CHOCÓ (COLOMBIA)

TESIS DOCTORAL

Presentado por:

Leidy Indira Hinestroza Córdoba

Dirigida por:

Dra. Noelia Betoret Valls

Septiembre de 2021

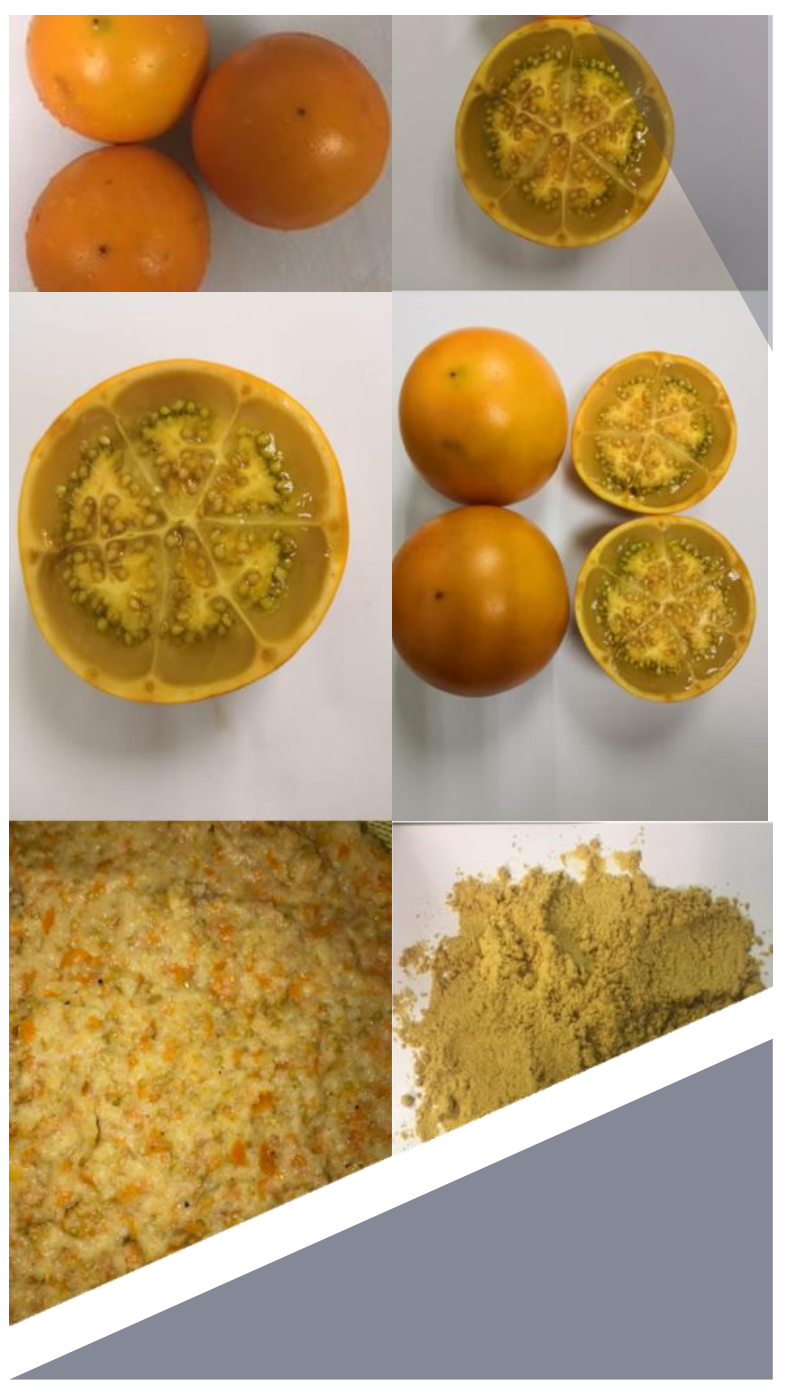




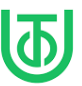

Universidad Tecnológica del Chocd Diego Luis Córdoba

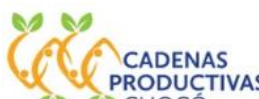

PRODUCTIV 
UNIVERSITAT POLITÈCNICA DE VALÈNCIA

INSTITUTO UNIVERSITARIO DE INGENIERÍA DE ALIMENTOS PARA EL DESARROLLO

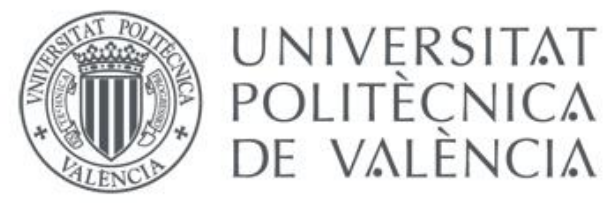

APLICACIÓN DE TECNOLOGÍAS SOSTENIBLES PARA EL DESARROLLO DE ALIMENTOS NUTRITIVOS Y SALUDABLES DIRIGIDOS A MEJORAR EL ESTADO NUTRICIONAL DE LA POBLACIÓN DEL DEPARTAMENTO DEL CHOCÓ (COLOMBIA)

TESIS DOCTORAL

Presentada por:

Leidy Indira Hinestroza Córdoba

Dirigida por:

Dra. Noelia Betoret Valls

Septiembre de 2021 




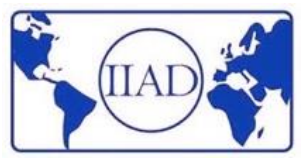

Dra. Noelia Betoret Valls, Profesora Titular de Universidad, perteneciente al Departamento de Tecnología de los Alimentos de la Universitat Politècnica de València

CONSIDERA que la memoria titulada "Aplicación de tecnologías sostenibles para el desarrollo de alimentos nutritivos y saludables dirigidos a mejorar el estado nutricional de la población del departamento del Chocó (Colombia)" que presenta $\mathbf{D}^{\mathbf{a}}$. Leidy Indira Hinestroza Córdoba para aspirar al grado de Doctora de la Universitat Politècnica de València, y que ha sido realizada bajo su dirección en el Instituto Universitario de Ingeniería de Alimentos para el Desarrollo de la Universitat Politècnica de València, reúne las condiciones adecuadas para constituir su tesis doctoral, por lo que AUTORIZA a la interesada para su presentación.

Fdo.: Noelia Betoret Valls 

A mi Familia y a Alicia (Q.E.P.D), quienes me inculcaron el valor de la disciplina y el sacrificio 



\section{MENCIÓN ESPECIAL}

Alicia Ríos Hurtado (Q.E.P.D); el puro azar hizo que nos encontramos en una cafetería de la Universidad Tecnología del Chocó. Nunca podré agradecer la confianza que depositaste en mí desde aquel día. Te convertiste en mi mentora y motor para cumplir mis sueños, me impulsaste a que creyera en mí y me esforzara para lograr muchísimas cosas buenas e incluso llegar, donde nunca imagine que llagaría. Has sido alguien especial para mí, tanto en lo personal como en lo profesional, me hiciste parte de tu círculo más cercano, me llamabas cariñosamente mi princesa y me considerabas una hija y yo a ti una segunda madre. Tú fuiste más allá con esta joven caprichosa y orgullosa, pero con ideas claras, fuiste la persona que me direccionó en el campo de la investigación, quien me abrió las puertas de su laboratorio, donde empezamos a planificar el proyecto de investigación de pregrado, cuando ni siquiera sabía que era la investigación. Gracias a su vocación de profesora, aprendí de ella lo que hoy sé... Me inculcó los valores del esfuerzo y el sacrificio, y sobre todo el de la disciplina, fue la persona que gestionó mi formación a nivel de maestría y doctorado. Gracias por ser parte de mi vida... iNunca te olvidaré!

Su liderazgo contribuyó a que muchos profesionales del departamento del Chocó en Colombia tuvieran la oportunidad de formarse a nivel de maestría y doctorado, su legado perdurara por siempre en mí. 

Ya ha llegado el día de cerrar este capítulo. No sin antes agradecer a todas las personas que contribuyeron a que este proyecto se cumpliera.

A Dios por haberme brindado la oportunidad de alcanzar un logro más en mi vida.

A mis padres Lucía Manuela Córdoba Rojas y Manuel Hinestroza Mena (Q.E.P.D). Sus bendiciones a lo largo de mi vida han contribuido para cumplir cada una de mis metas en lo personal y lo profesional, gracias por inculcarme valores y hacer de mí una profesional comprometida con el bienestar de mi región.

A mi hermano y mis hermanas Nilson Antonio, Maritza del Carmen, Yudy Elizath, Ketty Yaneth y Olga Lucía, por su apoyo incondicional durante todo el proceso de formación, porque me fortalecían en cada momento; gracias por apoyarme en los momentos más difíciles y siempre encontrar apoyo en ustedes.

A mis sobrinos y sobrinas, Didier, Nilson Alexander, Oscar Daniel, Keiner Andrés, Camilo Andrés, Sandro Herley, Kerin Samuel, Emanuel David y Jhulian Alexander, Jhanya Lucia y Liseth Carolina, gracias por ser esa voz de alimento desde la distancia y decirme todos los días: tía te quiero mucho y mi príncipe por decirme tía de amo mucho.

A mi cuñado y cuñada, Elkin y Stella por su apoyo y sus palabras de ánimo y gracias por ser parte de mi familia, Stella la quiero como una hermana.

A mi directora Noelia Betoret Valls, nunca podré agradecer lo suficiente. La confianza que ha depositado en mí y por acogerme en su grupo de investigación y direccionarme en la tesis doctoral; por sus palabras de ánimo en la etapa de formación doctoral, por hacerme sentir parte de su círculo más cercano de amistad. En Colombia tienen una amiga que siempre tendrá las puertas abiertas, en aras de seguir trabajando conjuntamente en proyectos de carácter investigador. Gracias por haberme acompañado hasta aquí.

Al proyecto FORTALECIMIENTO DE ENCADENAMIENTOS PRODUCTIVOS DE LA SUBREGIÓN DEL CHOCÓ - Número BPIN: 2013000100284 financiado por el Fondo de Ciencia Tecnología e Innovación CTel. (MINCIENCIA) del Sistema 
General de Regalías de Colombia, con recursos del departamento del Chocó y ejecutado por la Universidad Tecnológica del Chocó "Diego Luis Córdoba".

A la Universidad Tecnología del Chocó "Diego Luis Córdoba", por todo su apoyo y confiar en este proyecto que apenas comienza y que debe continuar.

Al Programa de Recuperación Nutricional - Asociación Humanitaria Niños del Chocó, a cargo de la Congregación Cristiana Hermanas de Caridad, por el apoyo y el espacio para obtener los datos.

A mis compañeros y compañeras de doctorado Ever, Sara, Eva, y Ramón, por sus consejos, y sus explicaciones, los cuales fueron de gran ayuda durante mi formación doctoral, por las palabras de ánimo en el momento que hacía falta.

Al joven Arnobio por su apoyo incondicional y fuiste la persona que estuve conmigo en casi todo el proceso de la tesis doctoral, estuviste siempre a mi lado ayudándome en lo que requería. Te quiero mucho y eres parte de mi familia. Gracias por todo.

Al joven Miller por su apoyo incondicional y por su disposición en todo. Gracias por tu ayuda en lo últimos días de mi tesis doctoral.

A mi amigo Miguel Ángel por sus conocimientos y por compartir conmigo los últimos días en España. Gracias por tus concejos en los momentos que requería. En Colombia tienen una amiga que siempre tendrá las puertas abiertas, en aras de realizar trabajos conjuntamente. Gracias por todo mi gruñón como cariñosamente te digo.

Al Dr. José Luis por sus conocimientos y gracias por invitarme a participar en sus proyectos y por sus palabras de ánimo en todo momento.

A mis compañeros y compañeras de Colombia Leider, Eric, Edinson, Armando, Andrés, Ezequiel, Jairo, Zamir, Evert, Gadafi, Franklin, Patricia y Sandra, por sus palabras de ánimo en todo momento. 


\section{RESUMEN}

La malnutrición, provocada tanto por el déficit de nutrientes como por el exceso de estos, es una realidad a nivel mundial, y resulta alarmante en los países en desarrollo, entre los que se encuentra Colombia. Las enfermedades no transmisibles derivadas de una ingesta inadecuada de nutrientes, afectan a una de cada tres personas en el mundo y son responsables del $45 \%$ de las muertes que se presentan a nivel mundial. Además, la excesiva industrialización y los intereses económicos de las grandes empresas han promocionado las dietas ricas en alimentos procesados, contribuyendo a la degradación ambiental y a la pérdida de biodiversidad.

Los Objetivos Globales de Desarrollo Sostenible (ODS) se establecieron en 2015 por parte de los principales líderes mundiales, como un importante compromiso por erradicar la pobreza, proteger el planeta y asegurar la prosperidad. En este contexto, los conceptos de soberanía alimentaria, economía circular, aprovechamiento integral y dieta sostenible recobran importancia y deben ser considerados a nivel de producción, transformación y comercialización, en el establecimiento de unos patrones alimentarios adecuados.

La presente tesis doctoral responde al interés de buscar alimentos alternativos, nutritivos y saludables, que permitan aprovechar los recursos naturales agroalimentarios autóctonos del departamento del Chocó (Colombia), y que contribuyan a mejorar el estado nutricional de su población infantil y adulta.

La importancia económica del fruto del lulo, su riqueza nutricional, accesibilidad y el elevado volumen de desperdicio asociado a la escasa industrialización, han provocado que este cultivo sea considerado por el gobierno colombiano como una de las cadenas productivas priorizadas para el desarrollo tecnológico y de innovación. Sobre este cultivo, se plantea la siguiente tesis doctoral, que tiene como objetivo general: Desarrollar productos medianamente procesados a partir del fruto del lulo mediante la aplicación de tecnologías sostenibles y/o innovadoras que garanticen la estabilidad de sus compuestos bioactivos y que permitan incluir otros, como los probióticos, de una forma controlada. Los productos irán dirigidos a la población adulta con problemas de obesidad e hipertensión y a la población 
infantil con problemas de desnutrición del departamento del Chocó (Colombia).

La consecución de este objetivo se aborda desde tres enfoques que configuran los tres capítulos en los que se ha estructurado el apartado de resultados: (i) Conocer las principales deficiencias de la población infantil, de entre 2 y 5 años, en Quibdó, una de las zonas más desfavorecidas del departamento del Chocó; (ii) determinar la adecuación del fruto de lulo para el desarrollo de alimentos que ayuden a paliar las diferentes formas de malnutrición en la población infantil y adulta. Y establecer las posibilidades de aplicación de tecnologías que garanticen la estabilidad de sus compuestos bioactivos y que permitan incluir otros, como los probióticos; (iii) determinar las características del residuo que pueda generarse a partir del fruto del lulo y proponer un procedimiento que asegure el aprovechamiento integral del mismo.

Los resultados del primer capítulo mostraron que, aunque las deficiencias en los principales macronutrientes en la población infantil no son alarmantes, sí que lo es el aporte de fibra y de micronutrientes como las vitaminas $\mathrm{A}$ y $\mathrm{C}$ y de minerales como el calcio. Esta situación está provocada, principalmente, por la ausencia total de la leche fresca y el escaso consumo de frutas y verduras. El lulo resultó ser, prácticamente, la única fruta que consumen, lo que confirma su elevada accesibilidad y aceptación. El desarrollo de productos medianamente procesados a partir del lulo mediante tecnologías que conserven e incluso aumenten la disponibilidad de su fibra y componentes bioactivos, se presenta como una estrategia prometedora.

En el segundo capítulo se realizaron dos trabajos de revisión que permitieron identificar los compuestos bioactivos y los microorganismos probióticos más relevantes en la prevención de las alteraciones fisiológicas asociadas a la hipertensión y la obesidad; y que establecieron el tratamiento de altas presiones de homogeneización (HPH) como una tecnología no térmica, adecuada para mejorar la calidad y funcionalidad de los zumos de frutas. Además, se determinaron las características macroestructurales, los parámetros de impregnación, y las propiedades fisicoquímicas y antioxidantes (capacidad antioxidante, contenido de fenoles totales y flavonoides, perfil de compuestos polifenólicos por LC-MS y contenido en espermidina) del fruto del lulo. Se evaluó el efecto de las presiones de homogeneización (50, 100 y 150 $\mathrm{MPa}$ ) sobre las mismas propiedades del zumo. Por último, se estudió la 
posibilidad de utilizar el zumo de lulo como sustrato para producir una bebida probiótica con Lactobacillus reuteri; se consideraron zumos de lulo a dos niveles de $\mathrm{pH}$ y dos niveles de tratamiento con $\mathrm{HPH}$ y se evaluó el efecto sobre el crecimiento de $L$. reuteri, las propiedades fisicoquímicas y antioxidantes y la resistencia de las células microbianas a la digestión gastrointestinal in vitro.

Los resultados obtenidos mostraron el lulo como una fruta con propiedades fisicoquímicas y funcionales ventajosas para el desarrollo de productos alimenticios saludables a partir de recursos autóctonos de la región del Pacífico colombiano. Sus características estructurales permiten la incorporación de protectores, conservantes, compuestos fisiológicamente activos $u$ otros aditivos. El perfil polifenólico obtenido por LC-MS, reveló la presencia de 288 compuestos pertenecientes a diferentes clases fenólicas (principalmente flavonoides y ácidos hidroxicinámicos). Además, el aumento de la presión del tratamiento de HPH incrementó la diversidad de polifenoles del zumo. El zumo de lulo también resultó ser una matriz adecuada para que Lactobacillus reuteri CECT 925 pueda llevar a cabo la fermentación dando lugar a un zumo con potenciales propiedades probióticas. Aunque los niveles de viabilidad fueron mayores en los zumos homogeneizados a $100 \mathrm{MPa}$ y $\mathrm{pH} 5,5$, en todas las muestras se logró una concentración mínima de $10^{7} \mathrm{UFC} / \mathrm{mL}$ al final del ensayo, concentración suficiente para que el microorganismo pueda ejercer sus efectos beneficiosos para la salud en el tracto intestinal del huésped.

En el último capítulo, se determinó la composición y las propiedades del bagazo resultante de obtener zumo de lulo y se valoraron diferentes procedimientos para realizar un aprovechamiento integral del mismo. Los resultados pusieron de manifiesto que el bagazo de lulo es una materia prima adecuada para obtener un polvo rico en fibra y carotenoides, que podría ser utilizado como ingrediente en la industria alimentaria y también a nivel doméstico. Se mostró un desequilibrio en la proporción entre fibra soluble e insoluble, lo que debería tenerse en cuenta en las aplicaciones posteriores y sobre todo si el producto se utiliza para alimentación infantil. 


\section{RESUM}

La malnutrició, provocada tant pel dèficit de nutrients com per l'excés d'aquests, és una realitat a nivell mundial, i resulta alarmant als països en desenvolupament, entre els quals es troba Colòmbia. Les malalties no transmissibles derivades d'una ingesta inadequada de nutrients afecten una de cada tres persones en el món i són responsables del $45 \%$ de les morts que es presenten a nivell mundial. A més, l'excessiva industrialització i els interessos econòmics de les grans empreses han promocionat les dietes riques en aliments processats, contribuint a la degradació ambiental i a la pèrdua de biodiversitat.

Els Objectius Globals de Desenvolupament Sostenible (ODS) es van establir en 2015 per part dels principals líders mundials, com un important compromís per erradicar la pobresa, protegir el planeta i assegurar la prosperitat. En aquest context, els conceptes de sobirania alimentària, economia circular, aprofitament integral i dieta sostenible recobren importància i han de ser considerats a nivell de la producció, la transformació i la comercialització, en l'establiment d'uns patrons alimentaris adequats.

La present tesi doctoral respon a l'interés de buscar aliments alternatius, nutritius i saludables, que permeten aprofitar els recursos naturals agroalimentaris autòctons del departament del Chocó (Colòmbia), i que contribuïsquen a millorar l'estat nutricional de la seua població infantil i adulta.

La importància econòmica del fruit del lulo, la seua riquesa nutricional, accessibilitat i l'elevat volum de desaprofitament associat a l'escassa industrialització, han provocat que aquest cultiu siga considerat pel govern colombià com una de les cadenes productives prioritzades per al desenvolupament tecnològic i d'innovació. Sobre aquest cultiu es planteja la següent tesi doctoral, que té com a objectiu general: Desenvolupar productes mitjanament processats a partir del fruit del lulo mitjançant l'aplicació de tecnologies sostenibles i/o innovadores que garantisquen l'estabilitat dels seus compostos bioactius i que permeten incloure uns altres, com els probiotics, d'una forma controlada. Els productes aniran dirigits a la població adulta amb problemes d'obesitat i hipertensió i a la població infantil amb problemes de desnutrició del departament del Chocó (Colòmbia). 
La consecució d'aquest objectiu s'aborda des de tres enfocaments que configuren els tres capítols en els quals s'ha estructurat l'apartat de resultats: (i) Conéixer les principals deficiències de la població infantil, d'entre 2 i 5 anys, en Quibdó, una de les zones més desfavorides del departament del Chocó; (ii) determinar l'adequació del fruit de lulo per al desenvolupament d'aliments que ajuden a pal-liar les diferents formes de malnutrició en la població infantil i adulta. I establir les possibilitats d'aplicació de tecnologies que garantisquen l'estabilitat dels seus compostos bioactius i que permeten inclouren d'altres, com els probiòtics; (iii) determinar les característiques del residu que puga generar-se a partir del fruit del lulo i proposar un procediment que assegure l'aprofitament integral d'aquest.

Els resultats del primer capítol mostraren que, encara que les deficiències en els principals macronutrients en la població infantil no són alarmants, sí que ho és l'aportació de fibra i de micronutrients com les vitamines $\mathrm{A}$ i C i de minerals com el calci. Aquesta situació está provocada, principalment, per l'absència total de la llet fresca en la dieta i l'escàs consum de fruites i verdures. El lulo resulta ser, pràcticament, l'única fruita que consumeixen, la qual cosa confirma la seua elevada accessibilitat i acceptació. El desenvolupament de productes mitjanament processats a partir del lulo mitjançant tecnologies que conserven $i$ fins $i$ tot augmenten la disponibilitat de la seua fibra i components bioactius, es presenta com una estratègia prometedora.

En el segon capítol es van realitzar dos treballs de revisió que van permetre identificar els compostos bioactius i els microorganismes probiotics més rellevants en la prevenció de les alteracions fisiològiques associades a la hipertensió i l'obesitat; i que van establir el tractament d'altes pressions d'homogeneïtzació (HPH) com una tecnologia no tèrmica, adequada per a millorar la qualitat i funcionalitat dels sucs de fruites. A més, es van determinar les característiques estructurals, els paràmetres d'impregnació, i les propietats fisicoquímiques $\mathrm{i}$ antioxidants (capacitat antioxidant, contingut de fenols totals i flavonoids, perfil de compostos polifenòlics per LC-MS i contingut en espermidina) del fruit del lulo. Es va avaluar l'efecte de les pressions d'homogeneïtzació (50, 100 i $150 \mathrm{MPa}$ ) sobre les mateixes propietats del suc. Finalment, es va estudiar la possibilitat d'utilitzar el suc de lulo com a substrat per a produir una beguda probiòtica amb Lactobacillus reuteri; es van considerar sucs de lulo a dos nivells de $\mathrm{pH}$ i dos nivells de tractament amb HPH 
i es va avaluar l'efecte sobre el creixement de Lactobacillus reuteri, les propietats físico-químiques $i$ antioxidants $i$ la resistència de les cèl-lules microbianes a la digestió gastrointestinal in vitro. Els resultats obtinguts van mostrar el lulo com una fruita amb propietats físico-químiques i funcionals avantatjoses per al desenvolupament de productes alimentosos saludables a partir de recursos autòctons de la regió del Pacífic colombià. Les seues característiques estructurals permeten la incorporació de protectors, conservants, compostos fisiològicament actius $\mathrm{O}$ altres additius. El perfil polifenólic obtingut per LC-MS, va revelar la presència de 288 compostos pertanyents a diferents classes fenòliques (principalment flavonoids i àcids hidroxicinámics). A més, l'augment de la pressió del tractament de HPH va incrementar la diversitat de polifenols del suc. El suc de lulo també va resultar ser una matriu adequada perquè Lactobacillus reuteri CECT 925 puga dur a terme la fermentació donant lloc a un suc amb potencials propietats probiòtiques. Encara que els nivells de viabilitat van ser majors en els sucs homogeneïtzats a $100 \mathrm{MPa}$ i pH 5,5, en totes les mostres es va aconseguir una concentració mínima de $10^{7} \mathrm{UFC} / \mathrm{mL}$ al final de la digestió gastrointestinal in vitro, concentració suficient perquè el microorganisme puga exercir els seus efectes beneficiosos per a la salut en el tracte intestinal de l'hoste.

En l'últim capítol, es va determinar la composició i les propietats del bagàs resultant d'obtindre suc de lulo i es van valorar diferents procediments per a realitzar un aprofitament integral d'aquest. Els resultats van posar de manifest que el bagàs de lulo és una matèria primera adequada per a obtindre una pols rica en fibra i carotenoids, que podria ser utilitzat com a ingredient en la indústria alimentària $\mathrm{i}$ també a nivell domèstic. Es va mostrar un desequilibri en la proporció entre fibra soluble i insoluble, la qual cosa hauria de tindre's en compte en les aplicacions posteriors i sobretot si el producte s'utilitza per l'alimentació infantil. 


\section{ABSTRACT}

Malnutrition, caused by both nutrients' deficit and excess, is a global reality, and it is alarming in developing countries, including Colombia. Noncommunicable diseases resulting from inadequate nutrient intake affect one in three people in the world and are responsible for $45 \%$ of global deaths. In addition, over-industrialization and corporate economic interests have promoted diets rich in processed foods, contributing to environmental degradation and biodiversity loss.

The Sustainable Development Goals (SDGs) were established in 2015 by major world leaders as a major commitment for ending poverty, fighting inequality, and addressing the urgency of climate change. In this context, the concepts of food sovereignty, circular economy, by-products recovery, and sustainable diet are gaining importance and need to be considered at the level of production, processing, and marketing, in the establishment of adequate food patterns.

This doctoral thesis responds to the interest in seeking alternative, nutritious, and healthy foods that make use of the natural agro-food resources native to the department of Chocó (Colombia), and that contribute to improving the nutritional status of its children and adult population.

The economic importance of the lulo fruit, its nutritional richness, accessibility and the high volume of waste associated with low industrialization, have led the Colombian government to consider this crop as one of the priority productions chains for technological development and innovation. The general objective of the following doctoral thesis is to develop moderately processed products from the lulo fruit through the application of sustainable and/or innovative technologies that guarantee the stability of its bioactive compounds and allow the inclusion of others, such as probiotics, in a controlled way. The final products will be aimed at the adult population with obesity and hypertension problems and the child population with malnutrition problems in the department of Chocó (Colombia).

The achievement of this objective is approached from three focuses that make up the three chapters in which the results section is structured: (i) To know the main deficiencies of the child population, aged between 2 and 5 years, in Quibdó, one of the most disadvantaged areas of the department of 
Chocó; (ii) to determine the suitability of the lulo fruit for the development of foods that help to alleviate the different forms of malnutrition in the child and adult population. And to establish the possibilities of applying technologies that guarantee the stability of its bioactive compounds and allow the inclusion of others, such as probiotics; (iii) to determine the characteristics of the residue that can be generated from the lulo fruit and propose a procedure that ensures its integral use.

The results of the first chapter showed that, although the deficiencies in the main macronutrients in the child population are not alarming, the deficiencies in fibre and micronutrients such as vitamins $\mathrm{A}$ and $\mathrm{C}$ and minerals such as calcium are alarming. This situation is mainly caused by the total absence of fresh milk in the diet and the low consumption of fruit and vegetables. Lulo was practically the only fruit consumed, which confirms its high accessibility and acceptability. The development of moderately processed products from lulo using technologies that preserve and even increase the availability of its fibre and bioactive components is a promising strategy.

In the second chapter, two review papers identified the most relevant bioactive compounds and probiotic microorganisms in the prevention of physiological alterations associated with hypertension and obesity,and established high-pressure homogenization treatment (HPH) as a non-thermal technology suitable for improving the quality and functionality of fruit juices. In addition, structural characteristics, impregnation parameters, physicochemical and antioxidant properties (antioxidant capacity, total phenol and flavonoid content, polyphenolic compound profile by LC-MS and spermidine content) of the lulo fruit were determined. The effect of homogenization pressures $(50,100$ and $150 \mathrm{MPa})$ on the same properties of the juice was evaluated. Finally, the possibility of using lulo juice as a substrate to produce a probiotic beverage with Lactobacillus reuteri was studied; lulo juices at two pH levels and two HPH treatment levels were considered and the effect on L. reuteri growth, physicochemical and antioxidant properties, and resistance of microbial cells to gastrointestinal digestion in vitro were evaluated. The results obtained showed lulo as a fruit with advantageous physicochemical and functional properties for the development of healthy food products from indigenous resources of the Colombian Pacific region. Its structural characteristics allow the incorporation of protectants, 
preservatives, physiologically active compounds, or other additives. The polyphenolic profile obtained by LC-MS revealed the presence of 288 compounds belonging to different phenolic classes (mainly flavonoids and hydroxycinnamic acids). In addition, increasing the pressure of the HPH treatment increased the polyphenol diversity of the juice. Lulo juice also proved to be a suitable matrix for Lactobacillus reuteri CECT 925 to carry out fermentation resulting in a juice with potential probiotic properties. Although viability levels were higher in the juices homogenized at $100 \mathrm{MPa}$ and $\mathrm{pH} 5.5$, a minimum concentration of $10^{7} \mathrm{CFU} / \mathrm{mL}$ was achieved in all samples at the end of in vitro gastrointestinal digestion, which is sufficient for the microorganism to exert its beneficial health effects in the host's intestinal tract.

In the last chapter, the composition and properties of the bagasse resulting from the production of lulo juice were determined and different procedures for its full utilization were evaluated. The results showed that lulo bagasse is a suitable raw material to obtain a powder rich in fibre and carotenoids, which could be used as an ingredient in the food industry and also at household level. An imbalance in the ratio between soluble and insoluble fibre was shown, which should be considered in subsequent applications and especially if the product is used for baby food. 



\section{ÍNDICE GENERAL}

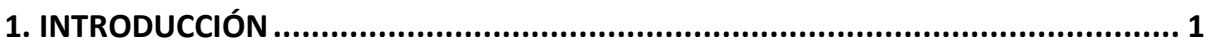

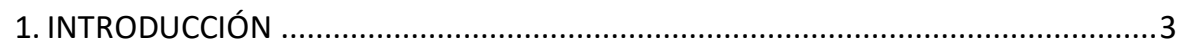

1.1. EL APROVECHAMIENTO DE LOS RECURSOS NATURALES, LA SOBERANÍA ALIMENTARIA Y LAS

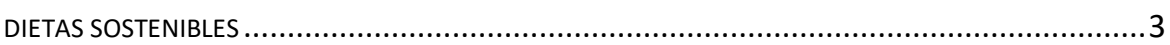

1.2. EL CULTIVO DEL LULO EN COLOMBIA ............................................................................. 5

1.2.1. Importancia económica del fruto de lulo en Colombia .............................6

1.2.2. El fruto de lulo y sus propiedades ........................................................... 8

1.3. LA OBESIDAD, LA HIPERTENSIÓN Y LA MALNUTRICIÓN EN EL SIGLO XXI ...........................10

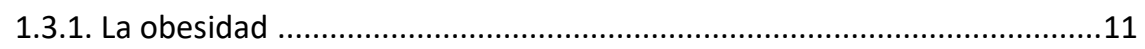

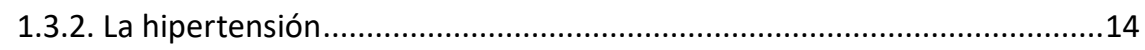

1.3.3. La malnutrición...................................................................................16

1.4. COMPUESTOS BIOACTIVOS DE INTERÉS EN EL TRATAMIENTO DE LA OBESIDAD Y/O

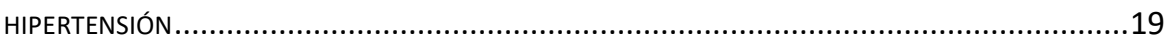

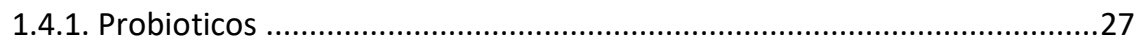

1.5. ESTRATEGIAS POLÍTICO-SANITARIAS ORIENTADAS A LA PREVENCIÓN Y/O DISMINUCIÓN DE LAS

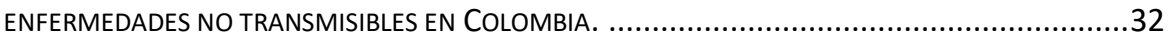

1.6. DESPILFARRO ALIMENTARIO, PROCESADO SOSTENIBLE Y ALIMENTOS NUTRITIVOS ................35

1.7. TECNOLOGíAS APLICADAS EN LA FABRICACIÓN DE ALIMENTOS FUNCIONALES........................38

1.7.1. La impregnación a vacío de alimentos ...................................................38

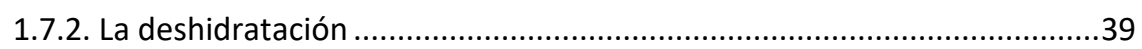

1.7.3. Las altas presiones de homogenización (HPH) ......................................40

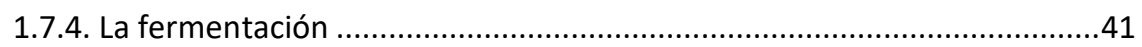

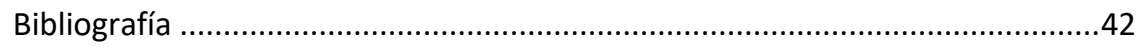

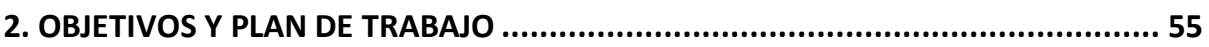

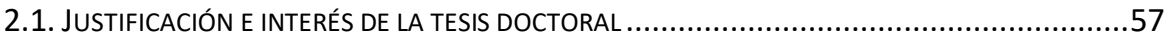

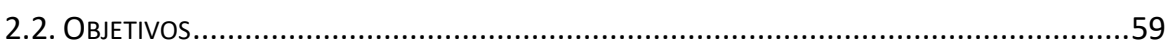

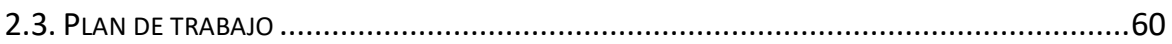

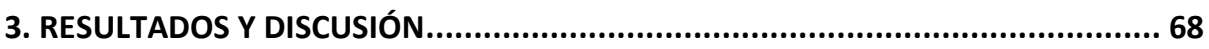

3.1. ESTUDIO NUTRICIONAL DE LA POBLACIÓN INFANTIL EN LA REGIÓN DEL CHOCó .....................70

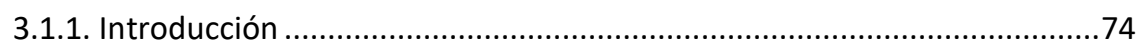

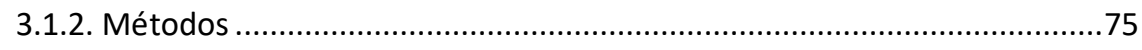

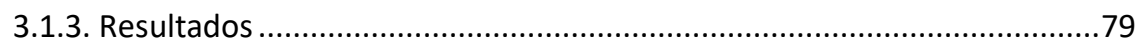

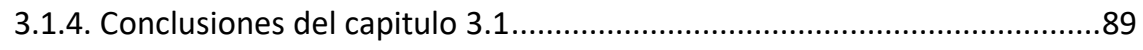

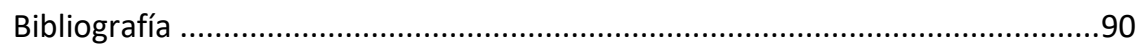

3.2. PosibiLIDADES DE DESARROLLO DE ALIMENTOS FUNCIONALES A PARTIR DEL FRUTO DEL LULO. APLICACIÓN DE TECNOLOGÍAS NO TÉRMICAS E INCORPORACIÓN DE PROBIÓTICOS. 
- Probiotics and other Bioactive Compounds with Proven Effect against Obesity and Hypertension. Food Design Opportunities from Lulo Fruit (Solanum quitoense) 104

- High Homogenization Pressures to Improve Food Quality, Functionality and Sustainability 134

- $\quad$ Potential Use of Vacuum Impregnation and High-Pressure Homogenization to Obtain Functional Products from Lulo Fruit (Solanum quitoense Lam.)

- Conclusiones del capítulo 3.2

3.3. FuENTES ALTERNATIVAS DE INGREDIENTES DE ALTO VALOR FUNCIONAL A PARTIR DE SUBPRODUCTOS DE LA INDUSTRIALIZACIÓN DE FRUTAS

- Characterization of Powdered lulo (Solanum quitoense) Bagasse as a Functional Food Ingredient.

- Conclusiones del capítulo 3.3 .249

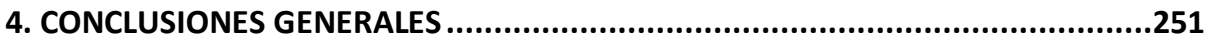

5. CONSIDERACIONES FINALES 255 



\section{ÍNDICE DE FIGURAS}

Figura 1.1. Área cosechada, producción y rendimiento del lulo (Solanum quitoense Lam) a nivel regional

Figura 1.2. Participación porcentual en la producción del lulo por departamentos.

Figura 1.3. Fruto de lulo (Solanum quitoense Lam) en el punto óptimo de madurez para el consumo

Figura 1.4. Causas de mortalidad en Colombia.

Figura 2.1. Diagrama de flujo seguido en la ejecución de los puntos 4 y 5 del plan de trabajo dirigidos a la consecución de los objetivos específicos 1.4 y 1.5 .

Figura 2.2. Diagrama de flujo seguido en la ejecución de los puntos 6 y 7 del plan de trabajo dirigidos a la consecución de los objetivos específicos 1.6, 1.7 y 1.8

Figura 2.3. Diagrama de flujo seguido en la ejecución de los puntos 8 y 9 del plan de trabajo dirigidos a la consecución de los objetivos específicos 1.9 , 1.10 y 1.11.

Figura 3.1. Documento proporcionado a las familias para la valoración nutricional

Figura 3.2. Distribución de los alimentos en las comidas y alimentos más consumidos.

Figura 3.3. Porcentaje de encuestados con un determinado índice de adecuación al patrón alimentario recomendado diario.

Figura 3.4. Distribución porcentual de ingesta de alimentos por grupos alimenticios en el desayuno. a: hidratos de carbono, b: vitaminas y minerales, c: proteínas y d: grasas.

Figura 3.5. Distribución porcentual de ingesta de alimentos por grupos alimenticios en el almuerzo. a: hidratos de carbono, b: vitaminas y minerales, c: proteínas y d: grasas

Figura 3.6. Distribución porcentual de ingesta de alimentos por grupos alimenticios en la cena. a: hidratos de carbono, b: vitaminas y minerales, c: proteínas y d: grasas.

Figura 3.7. Esquema de una sección transversal del fruto de la naranjilla . 188 Figura 3.8. Micrografías (Cryo-SEM) del tejido del fruto de lulo fresco correspondientes al mesocarpo ((a) y (b)) y al endocarpo ((c) y (d)). 



\section{ÍNDICE DE TABLAS}

Tabla 1.1. Categoría de clasificación de la hipertensión.

14

Tabla 1.2. Recopilación de estudios que muestran algunos compuestos

bioactivos y su efecto probado sobre la obesidad e hipertensión. .24

Tabla 1.3. Recopilación de estudios que muestran algunos microorganismos probioticos y su efecto probado sobre la obesidad e hipertensión. 29

Tabla 1.4. Compuestos bioactivos y métodos de extracción aplicados en subproductos de frutas.

Tabla 3.1. Relación entre el patrón alimentario recomendado y las recomendaciones internacionales de ingesta de nutrientes para la población colombiana de 2 a 5 años de edad. 

Introducción

\section{INTRODUCCIÓN}




\section{INTRODUCCIÓN}

\subsection{El aprovechamiento de los recursos naturales, la soberanía alimentaria y las dietas sostenibles}

En la actualidad, el aprovechamiento sostenible de los recursos naturales se ha convertido en una prioridad a nivel mundial [1]. La producción agrícola y el uso de la tierra, la transformación alimentaria y el consumo de energía, la generación de residuos alimentarios y de gases contaminantes han experimentado, en las últimas décadas, cambios abruptos e insostenibles a gran escala. El cambio climático, la desnutrición y la alta incidencia de enfermedades no transmisibles como la hipertensión y la obesidad son una realidad [2]. Todos estos cambios aumentan las desigualdades y la inseguridad alimentaria.

Se estima que las prácticas agrícolas representan aproximadamente el $34 \%$ del uso mundial de la tierra, lo que equivale a un $70 \%$ de uso del agua para fines humanos y a la producción del $98 \%$ de los gases mundiales de efecto invernadero [3]. En estas condiciones el sistema alimentario, además de insostenible, resulta insuficiente y no contribuye a la salud y adecuada nutrición de la población.

En 2015, los principales líderes mundiales adoptaron los Objetivos Globales de Desarrollo Sostenible (ODS) y se comprometieron a erradicar la pobreza, proteger el planeta y asegurar la prosperidad como parte del nuevo desarrollo sostenible en los 15 años siguientes. Sin embargo, aunque se han hecho esfuerzos desde las diferentes organizaciones y países desarrollados e industrializados, los avances hasta el momento resultan insuficientes [4].

"El estado de la seguridad alimentaria y la nutrición en el mundo" es el estudio mundial más completo en relación con el seguimiento de los progresos realizados en los últimos años hacia la erradicación del hambre y la malnutrición. Lo elaboran conjuntamente la Organización de las Naciones Unidas para la Alimentación y la Agricultura (FAO), el Fondo Internacional de Desarrollo Agrícola (FIDA), el Fondo de las Naciones Unidas para la Infancia (UNICEF), el Programa Mundial de Alimentos (PMA) y la Organización Mundial de la Salud (OMS). En la última edición [5] se estima que casi 690 millones de 
personas pasaban hambre en 2019 (un aumento de 10 millones de personas desde 2018 y de casi 60 millones en cinco años). Los altos costos y la escasa asequibilidad de algunos alimentos impiden también a miles de millones de personas lograr una alimentación saludable y nutritiva. Según las previsiones del informe, la pandemia de la enfermedad por coronavirus (COVID-19) podría provocar, a finales de 2020, un aumento de 130 millones en el número de personas afectadas por el hambre crónica en todo el mundo.

La globalización de los mercados ha provocado cambios en los patrones alimentarios. La industrialización y los intereses económicos de las grandes empresas han promocionado las dietas ricas en carnes, lácteos, aceites, sal y gran cantidad de alimentos procesados, contribuyendo a la degradación ambiental y a la pérdida de biodiversidad.

En este contexto, el término soberanía alimentaria recobra importancia. La soberanía alimentaria aboga por la protección de los recursos naturales y la biodiversidad. Con el objetivo de contribuir a la reducción del hambre y la pobreza, la soberanía alimentaria recoge el derecho de toda nación a mantener, producir y desarrollar su propio alimento, así como también el derecho a alimentos saludables, respetando la cultura mediante métodos ecológicos y sostenibles [6]. La sostenibilidad se considera como el principio del desarrollo económico y está relacionado con diferentes aspectos ambientales, sociales y económicos.

En los últimos años, la Organización de las Naciones Unidas para la Alimentación y la Agricultura (FAO) ha impulsado un proceso de transición hacia un sistema alimentario más saludable y sostenible. Ha introducido el concepto de dieta sostenible que reconoce la interconexión de todos los agentes del sistema alimentario y su efecto sobre la disponibilidad y calidad de los alimentos, los recursos naturales, los medios de vida y la equidad social [7], [8], [9]. La dieta sostenible se define como aquella dieta de bajo impacto ambiental, que contribuye a la seguridad alimentaria y nutricional, ayudando a una vida saludable para las generaciones presentes y futuras. Las dietas sostenibles protegen y respetan la biodiversidad y los ecosistemas, son culturalmente aceptables, accesibles, económicamente justas y asequibles. Proporcionan alimentos nutricionalmente adecuados, seguros y saludables, optimizando los recursos naturales y humanos [10]. Las dietas sostenibles incluyen gran cantidad de frutas y hortalizas, frutos secos, legumbres y semillas y promueven la soberanía alimentaria. Además, está bien establecido 
que una dieta rica en frutas y verduras es beneficiosa para la salud y disminuye el riesgo de enfermedades cardiovasculares, de obesidad e hipertensión e incluso de cáncer [11].

\subsection{El cultivo del Iulo en Colombia}

Por su ubicación geográfica y su amplia variedad de climas, Colombia es el tercer país del mundo con una gran biodiversidad y el cuarto país en términos de recursos hidrográficos. Alberga, aproximadamente, el $10 \%$ de las especies del mundo (aproximadamente 51.220 especies de plantas, de las cuales el $30 \%$ son endémicas, y algunas están bajo protección); y el $20 \%$ de su superficie se dedica a la producción de frutas (con una producción total de aproximadamente 9,5 millones de toneladas) [12].

Sin embargo, su rica biodiversidad está cada vez más amenazada por varios factores, tales como la deforestación, la minería y los sistemas agroalimentarios intensivos [13]. Actualmente, Colombia es uno de los principales productores de frutas tropicales frescas a nivel mundial. Pese a lo anterior, se estima que el $64 \%$ de la población y el $70 \%$ de los niños viven en condiciones de pobreza extrema. Además, en los últimos años, Colombia se enfrenta a un problema de salud pública, debido a que el sobrepeso y la obesidad se han convertido en las principales causas de mortalidad [14]. En estas condiciones, la transformación del sistema alimentario de acuerdo con los principios de la soberanía alimentaria y las dietas sostenibles es un reto. Los recursos autóctonos deben ser utilizados respetando la biodiversidad y contribuyendo a la mejora del estado nutricional y de salud de su población.

El Chocó es uno de los treinta y dos departamentos de Colombia. Se encuentra localizado en el noroeste del país, en la región del Pacífico colombiano. Cuenta con tres de las principales cuencas hidrográficas (los ríos Atrato, San Juan y Baudó) y está bañado por las costas del océano Pacífico y Atlántico. Este territorio está dividido por cinco subregiones: Darién, Pacifico Norte, Pacifico Sur, San Juan y Atrato. La población estimada para el departamento del Chocó es de 534.826 habitantes, y está integrada por la mayor densidad de población afrocolombiana del país con un $82,70 \%$, (lo que representa el 6,6\% de la población étnica nacional); seguida por los grupos indígenas que representan un 12,7\% (equivalente al 3,2\% del país); y otro restante que no se identifica con ningún grupo étnico. Con respecto a la 
distribución por edades, la población chocoana es relativamente joven, menor de 18 años [15].

Esta región cuenta, aproximadamente, con 4.525 especies de plantas distribuidas entre frutales, vegetales, plantas medicinales y alimenticias [16]. Sin embargo, pese a esta riqueza natural, este departamento es uno de los más pobres de la nación. El índice de condiciones de vida solo llega al 55,3\%, el desempleo es del $21 \%$, y posee la tercera tasa de mortalidad más alta por muertes en la población infantil [15]. Según el análisis de Situación de Salud realizado y publicado por el Ministerio de Salud y Protección Social (MINSALUD) en 2019, [17] alrededor del 25,7\% de la población adulta padece problemas de hipertensión y obesidad, cifra que en los últimos años no ha sido actualizada debido a que no existe una planificación de las diferentes instituciones.

Algunas investigaciones realizadas han permitido evaluar las potencialidades de algunas frutas y vegetales de esta región, en torno a los cuales se han desarrollado diferentes procesos tecnológicos y una gran variedad de productos útiles para la industria alimentaria. No obstante, hoy en día es poca la información sobre muchas especies tropicales que podrían incluirse como nuevas alternativas de aprovechamiento, con características funcionales, para el desarrollo de nuevos productos que aporten valor agregado a los recursos existentes de la región.

\subsubsection{Importancia económica del fruto de lulo en Colombia}

El fruto del lulo (Solanum quitoense Lam) se presenta como un fruto de interés nacional y regional. El fruto de lulo en Colombia representa un papel histórico conociéndose como el "fruto dorado de los Andes" por sus propiedades funcionales. En la región andina se cultiva la variedad Solanum quitoense Lam y en la región del Pacífico la variedad Solanum sessiliflorum Dunal. Esta tesis doctoral se centra en la especie de Solanum quitoense Lam, fruto que se produce al interior de Colombia y que tiene una producción identificada, así como también, un mercado internacional definido, siendo Europa, Corea y Japón los principales destinos de exportaciones del fruto de Iulo [18].

En Colombia, el lulo es un cultivo de importancia económica. La superficie cultivada, según el Ministerio de Agricultura y Desarrollo Rural en el 
año 2018 , fue de 10.307 ha con una producción de 82.354 T y un rendimiento promedio de 9,70 T/ha. Los departamentos productores son Huila, Tolima, Valle del Cauca, Antioquia, Boyacá y Chocó. En la Figura 1.1 se observa la evolución de área cosechada, la producción y el rendimiento del cultivo de lulo en Colombia durante el periodo 2010-2018.

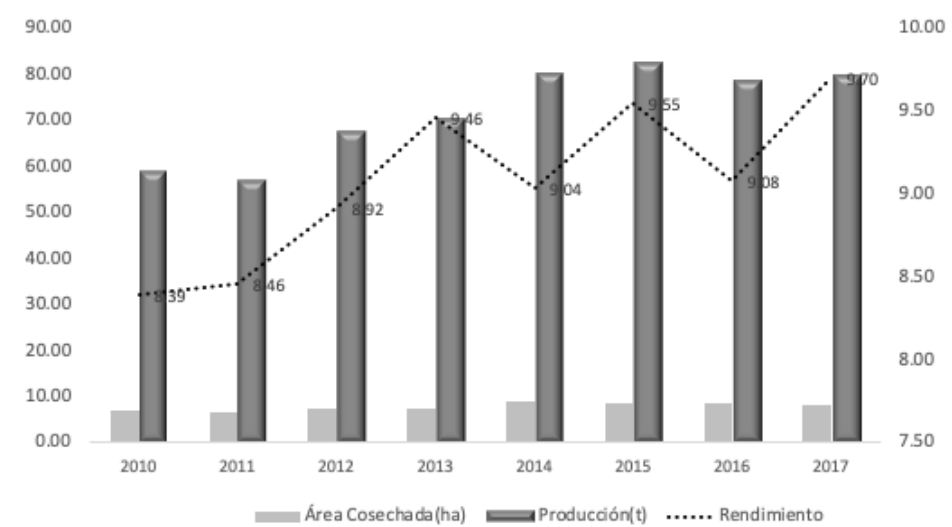

Figura 1.1. Área cosechada, producción y rendimiento del lulo (Solanum quitoense Lam) a nivel regional basado en los datos de Agronet (2017).

La producción de lulo en Colombia (Figura 1.2), se ha centrado en los departamentos de Huila, Valle del Cauca, Antioquia, Cauca y Boyacá generando una producción que representa el 58\% de la producción nacional, frente a los 19 departamentos restantes cuya producción representa el 40\% de la producción nacional $[19,20]$.

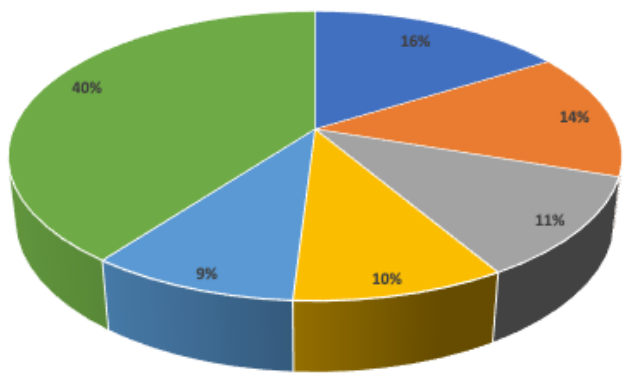

- Huila " Valle del Cauca = Antioquia a Boyacá - Cauca | Resto de departamentos

Figura 1.2. Participación porcentual en la producción del lulo por departamentos. 
El comercio de lulo a nivel mundial ha provocado un aumento del interés en su producción. Los principales destinos de las exportaciones son: Francia, España, Panamá, Holanda, Brasil, Canadá, Italia, Rusia, Estados Unidos, Antillas Holandesas, Emiratos Árabes, Japón y Corea [20]. Las exportaciones afectan tanto a la fruta fresca como a la fruta procesada en forma de trozos, pulpa congelada o jugo.

El Ministerio de Agricultura y el viceministro de Desarrollo Rural en Colombia han financiado, para el periodo 2021-2022, numerosas propuestas de alianzas productivas en 23 departamentos. Uno de los objetivos es el aumento de la producción y la promoción de la industrialización. Algunas de estas propuestas se indican a continuación:

- $\quad$ Fortalecimiento de la producción y comercialización del cultivo de lulo aplicando las buenas prácticas agrícolas y de postcosecha. Municipio de Balboa-Departamento de Cauca (Colombia).

- $\quad$ Establecimiento de 40 hectáreas de cultivo de lulo cocona o lulo chocoano con productores de hortalizas y frutas. Municipio de BojayáDepartamento del Chocó (Colombia).

Apoyo técnico a las prácticas de manejo del cultivo de lulo a productores de Asopromafruc. Municipio de Labateca-Departamento Norte de Santander (Colombia).

Implementación de un proceso de cruzamiento Solanum quitoense y Solanum sessiflorum. Centro Agroindustrial-Departamento del Meta (Colombia).

\subsubsection{El fruto de lulo y sus propiedades}

El fruto de lulo (Solanum quitoense Lam) es una planta perenne nativa del noroeste de América del Sur. Pertenece a la familia Solanáceas, genero Solamun, y se considera uno de los grupos más grandes de las angiospermas. Pertenece al subgénero Leptostemonum que incluye, aproximadamente, 1500 especies en todo el mundo [18].

Se trata de un fruto esférico de entre 3 a $8 \mathrm{~cm}$ de diámetro, de color verde claro cuando esta verde y naranja brillante cuando está maduro. La estructura interna del fruto es similar a la del fruto del tomate. La pulpa del 
fruto es de color verde-amarillenta y se distribuye en cuatro compartimentos separados por particiones membranosas (Figura 1.3).

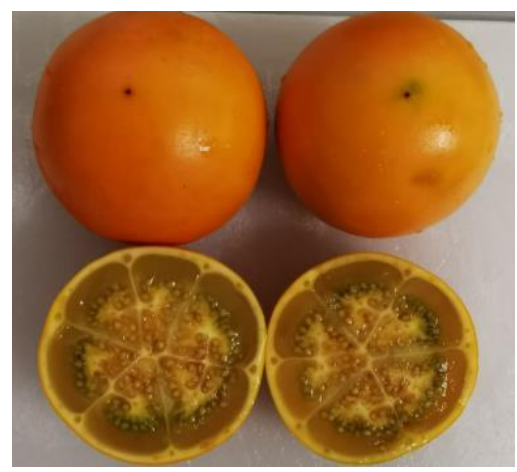

Figura 1.3. Fruto de lulo (Solanum quitoense Lam) en el punto óptimo de madurez para el consumo.

Es fuente de fibra, ácidos orgánicos (ácido cítrico), minerales (fósforo, calcio y hierro), vitamina $C$, compuestos fenólicos, además de carotenoides (luteína, $\beta$-caroteno y zeaxantina entre otros) y posee una elevada capacidad antioxidante [21,22,23]. El lulo contiene dos compuestos amargos; la espermidina $\quad \mathrm{N}^{1}, \mathrm{~N}^{4}, \mathrm{~N}^{8}$-tris(dihidrocafeílo) y la espermidina $\mathrm{N}^{1}, \mathrm{~N}^{8}$ bis(dihidrocafeílo), que actúan como aminas bioactivas [24].

Algunas de las actividades de investigación llevadas a cabo en los últimos años en Colombia han permitido avanzar en los aspectos relacionados con las propiedades fisicoquímicas y funcionales que se indican a continuación:

- Se establecieron metodologías apropiadas para el manejo integral del cultivo del fruto de lulo y se evaluaron las principales propiedades fisicoquímicas relacionadas con su aceptación organoléptica: color, pectinas, ácidos orgánicos, enzimas, sabor y aroma (Universidad de Quindío-Colombia).

- El procesado del lulo en forma de zumo provoca la aparición de un ligero sabor amargo que se debe a diferentes aminas bioactivas. Estas aminas otorgan al zumo de lulo propiedades funcionales relacionadas con el control de la hipertensión [24]. Es importante mencionar, que las comunidades afrocolombianas usan el fruto de lulo para la elaboración de infusiones que ayudan a la prevención de la hipertensión. También, se identificaron y cuantificaron compuestos activos como el (Z)-3-hexenal, 
butanoato de etilo, acetato de 3-sulfanilhexilo y hexanoato de etilo, que son los principales responsables del característico aroma de esta fruta [22].

- El grupo de investigación de Valoración y Aprovechamiento de la Biodiversidad de la Universidad Tecnológica del Chocó, recientemente y mediante el proyecto "Fortalecimiento de los encadenamientos producto de las subregiones del Chocó" fomentó incrementar los niveles de desarrollo tecnológico e innovación de la cadena de lulo y de la cadena del plátano en las subregiones del Chocó.

- Alpina Productos Alimenticios Colombia S.A, incursiona en el mercado una línea de jugo de lulo, con gran aceptación para los consumidores.

\subsection{La obesidad, la hipertensión y la malnutrición en el siglo XXI}

La alimentación y la dieta juegan un papel clave en la salud y en la prevención de enfermedades. En las últimas décadas la prevalencia de enfermedades no transmisibles (fundamentalmente diabetes, obesidad e hipertensión) se ha convertido en un problema de salud pública. Este hecho ha ido unido a un aumento de la preocupación por los hábitos alimenticios; cada vez se acepta más la idea de que muchas de las enfermedades no transmisibles pueden prevenirse con una adecuada alimentación. Ya es un hecho científicamente demostrado que, una dieta basada en alimentos vegetales va asociada a un menor riesgo de enfermedades no trasmisibles [25].

Gran parte de los beneficios asociados a las dietas ricas en alimentos vegetales se han atribuido a compuestos bioactivos como los polifenoles y los carotenoides. Existen multitud de estudios científicos publicados dirigidos a: Determinar el contenido de estos compuestos en gran variedad de frutas, hortalizas y legumbres [26]; a comprender los mecanismos por lo que estos compuestos bioactivos ejercen su función [27]; a establecer el efecto de las operaciones de procesado sobre la biodisponibilidad de los mismos [28]; y a determinar la funcionalidad de los alimentos vegetales mediante estudios in vitro e in vivo[27]. 


\subsubsection{La obesidad}

La obesidad es una enfermedad crónica, compleja y multifactorial que afecta a millones de personas y que se caracteriza por el aumento de la grasa corporal que conforma el tejido adiposo. La principal causa del sobrepeso y la obesidad es el desequilibrio energético entre calorías consumidas y gastadas, y va asociada en la mayoría de los casos a una dieta alta en calorías y a un bajo nivel de actividad física.

Sin embargo, factores ambientales, sociales, económicos y educativos son los responsables, en última instancia, de las dietas desequilibradas. La incidencia de obesidad aumenta en los países más pobres y disminuye en los países ricos. Dentro de los países, la obesidad se distribuye de forma no lineal; en los países pobres la obesidad aumenta con el aumento de los ingresos; en los países medios no hay esa relación; y la obesidad disminuye en los países ricos. Las mujeres son más obesas que los hombres en los países de ingresos bajos y también en los países de ingresos medios. La brecha desaparece en los países de economía más alta. De acuerdo con la distribución geográfica, la obesidad también cambia desde las zonas urbanas de los países más pobres hasta las zonas rurales de los países más ricos. Además, las tasas de obesidad continúan aumentando en todo el mundo y en todos los sectores de población [29].

En la práctica, el método más utilizado para diagnosticar el sobrepeso y la obesidad consiste en medir el índice de masa corporal (IMC), que se calcula dividiendo el peso en $\mathrm{Kg}$ por el cuadrado de la altura en $\mathrm{cm}$. Se considera sobrepeso cuando el IMC es igual o superior a $25 \mathrm{~kg} / \mathrm{m}^{2}$ y se considera obesidad cuando IMC es igual o superior a $30 \mathrm{~kg} / \mathrm{m}^{2}$ [30]. Aunque el IMC es una estimación aproximada, proporciona una medida a nivel poblacional del sobrepeso y la obesidad tanto para hombres como para mujeres de todas las edades.

El sobrepeso y la obesidad se asocian con la incidencia de desequilibrios, como la presión arterial alta (hipertensión), los niveles altos de azúcar en la sangre (hiperglucemia), los triglicéridos séricos altos, el desequilibrio entre lipoproteínas de alta densidad (HDL) y lipoproteínas de baja densidad (LDL), etc. Estos desequilibrios aumentan directamente el riesgo de padecer enfermedades cardiovasculares, diabetes tipo 2 y síndrome metabólico. Desde 1975 se ha triplicado la obesidad en todo el mundo; en 
2020 el 38,9\% de la población adulta tiene sobrepeso y un 13,1\% presenta obesidad. El sobrepeso y la obesidad contribuyen aproximadamente a 4 millones de muertes, lo que representa el 7,1\% de todas las muertes y 120 millones de años de vida saludable perdidos [30]. La obesidad fue declarada por la Organización Mundial de la Salud como una epidemia mundial, un problema de salud pública del siglo XXI [30].

La obesidad en niños y adolescentes también se ha convertido en un problema de salud pública, tanto en los países desarrollados como en los países en desarrollo. Se estima que el sobrepeso y la obesidad continuarán aumentando y entre el $75 \%$ y el $80 \%$ de los adolescentes actuales se convertirán en adultos obesos [31]. La Organización Mundial para la Salud estimó en 2020, que 41 millones de niños menores de cinco años padecen sobrepeso y obesidad. Se prevé que esta cifra alcance el valor de 43 millones en 2025. En Estados Unidos, los valores han aumentado a más del doble y también en los países europeos. Aunque la prevalencia total de obesidad sigue siendo menor en la población infantil que en los adultos, la obesidad infantil esta asociada con varias comorbilidades que, a menudo, contribuyen al desarrollo de enfermedades cardiovasculares asociadas a un aumento de la presión arterial, de la resistencia a la insulina, de la hiperlipidemia, y de la diabetes tipo $2[32,33]$.

Según un estudio llevado a cabo en Estados Unidos, el coste asociado a la obesidad y a las enfermedades relacionadas supone un gasto mensual de 190 mil millones de dólares aproximadamente, lo que representa un 20,6\% del gasto en atención médica [34].

Colombia es uno de los países con tasas de crecimiento de sobrepeso y obesidad. Según los últimos datos disponibles (cifras agregadas de la Encuesta Nacional de Nutrición de Colombia 2015: ENSIN), [35], los adultos que presentan un IMC >25, correspondiente a sobrepeso, representan el 56\%, y el $19 \%$ son obesos (con IMC > 30). La obesidad es más frecuente en las mujeres (22,4\%) que en los hombres (14,4\%). Las entidades gubernamentales y privadas muestran que uno de cada seis niños y adolescentes tiene sobrepeso u obesidad, siendo los datos más preocupantes los de las regiones de Orinoquia y Amazonía (21,8\%), Pacífica $(21,0 \%$ ) y Atlántica $(19,9 \%)$, que superan el promedio nacional [17]. En la Figura 1.4. Se muestran las causas de mortalidad en Colombia. 


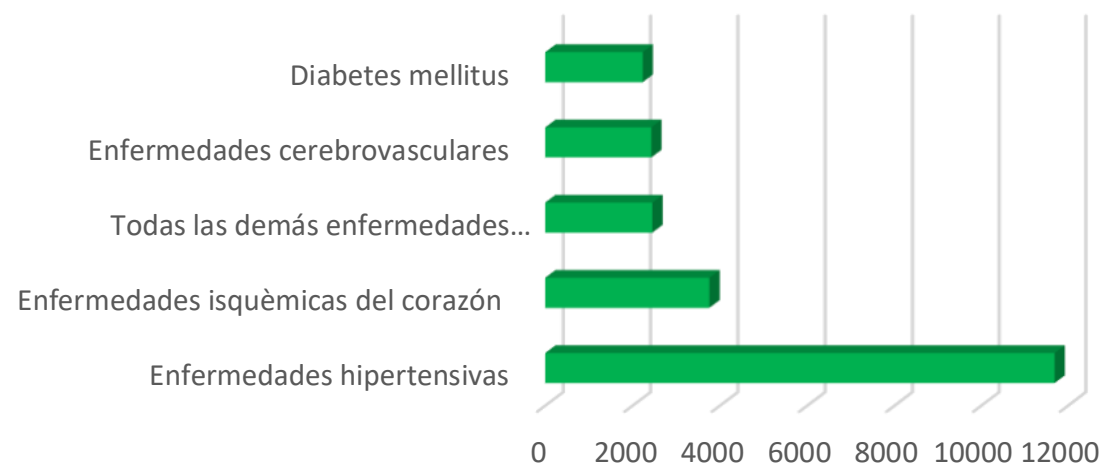

Figura 1.4. Causas de mortalidad en Colombia (Ministerio de Salud y Protección de Salud, 2019).

Tras la Declaración Política sobre enfermedades no transmisibles (ENT) adoptada por la Asamblea General de las Naciones Unidas en 2011, los países miembros de la OMS aprobaron la Estrategia Mundial sobre Dieta y Actividad Física, así como también sobre el seguimiento y monitoreo a las ENT. En esta declaración se introdujeron nueve objetivos para la reducción de las enfermedades no transmisibles (sobrepeso, obesidad, enfermedades cardiovasculares, cáncer, enfermedades pulmonares crónicas y diabetes). Además, se aprobó un nuevo plan de acción mundial (2018-2030) sobre actividad física para los estados miembros. En el plan se establecen pautas y objetivos claros para que se mantengan los niveles de salud, así como también una dieta orientada al bienestar de la sociedad [36,37].

La industria alimentaria tiene un papel fundamental en conseguir que los alimentos sean seguros, nutritivos (bajos en grasas, azúcar y sal), sabrosos, convenientes, accesibles y asequibles para todos los consumidores, contribuyendo a una dieta equilibrada y a un estilo de vida saludable [38].

Las instituciones colombianas trabajan con los diferentes sectores de la industria alimentaria, diseñando estrategias relacionadas con la dieta y el procesado de productos bajos en grasas, azúcar y sal. La Encuesta Nacional de Situación Nutricional (ENSIN) dispone de datos en los que, aproximadamente, la mitad de los adultos realizan actividad física entre moderada (150 minutos) y fuerte (75 minutos) como recomienda la Organización Mundial para la Salud, lo cual no es suficiente. El gobierno colombiano ya ha establecido un impuesto a los productos que aporten un alto contenido calórico, y ha disminuido entre 
el $10 \%$ y $30 \%$ el impuesto a las frutas y hortalizas, con el fin de favorecer el consumo de estas en la población de ingresos bajos y medios.

\subsubsection{La hipertensión}

La hipertensión arterial, así como la obesidad, es un problema creciente que representa un desafío de salud a nivel mundial. Según la European Society Cardiology (ESC) y la European Society of Hypertension (ESH), la hipertensión es reconocida como la principal causa prevenible de morbilidad y mortalidad en todo el mundo asociada a enfermedades cardiovasculares [39].

Se define la hipertensión como la tensión arterial alta o elevada, con valores de presión arterial sistólica $\geq 140 \mathrm{mmHg}$ y de presión arterial diastólica $\geq 90 \mathrm{mmHg}$ [40]. En la tabla 1.1 se presentan los valores que determinan los diferentes grados de hipertensión arterial. La hipertensión primaria es el tipo más común, con el $90-95 \%$ de los casos identificados. Está causada por diferentes factores que incluyen un estilo de vida no saludable: falta de potasio o aumento de ingesta de sodio, falta de actividad física, estrés y obesidad. Sin embargo, también se ve afectada por factores sociodemográficos que podrían incluir la carga genética, raza, etnia, sexo, edad y el nivel socioeconómico. Datos recientes muestran que la prevalencia es mucho mayor en las personas de raza negra, que la blanca. Así, en África, la hipertensión arterial es alrededor del $46 \%$ más alta que en otros países del mundo. Los informes nacionales han indicado que la prevalencia de muerte prematura aumenta en los países de ingresos bajos y medios donde alcanza valores del $31,5 \%$ frente al $28,5 \%$ de los países de ingresos altos $[41,42]$.

Tabla 1.1. Categoría de clasificación de la hipertensión [39].

\begin{tabular}{lcc}
\hline Categoría & Sistólica $(\mathrm{mmHg})$ & Diastólica $(\mathrm{mmHg})$ \\
\hline Óptimo & $<120$ & $<80$ \\
\hline Normal & $120-129$ & $80-84$ \\
\hline Normal alto & $130-139$ & $85-89$ \\
\hline Hipertensión grado 1 (leve) & $140-159$ & $90-99$ \\
\hline Hipertensión grado 2 (moderada) & $160-179$ & $100-109$ \\
\hline Hipertensión grado 3 (grave) & $\geq 180$ & $\geq 110$ \\
\hline
\end{tabular}


La hipertensión es el principal factor de riesgo de la enfermedad cardiovascular $[53,54,55]$. La hipertensión arterial y las enfermedades asociadas son responsables de más de 9,4 millones de muertes en todo el mundo y se prevé que aumenten más en 2025 [43]. Según la OMS, es una de las principales causas de muerte prematura y afecta, aproximadamente, a 1,13 mil millones de personas en todo el mundo. Su elevada incidencia genera costos muy elevados en los sistemas generales de salud; en los Estados Unidos, se estima que los costes directos e indirectos relacionados con enfermedades cardiovasculares superaron los 315 mil millones de dólares y se espera que superen el billón de dólares anuales en 2030. En Colombia, según el Ministerio de Salud y Protección Social la prevalencia de la hipertensión es del $22 \%$. Sin embargo, de acuerdo con la nueva clasificación científica realizada por la European Society Cardiology (ESC) y la European Society of Hypertension (ESH), la prevalencia real sería del 43,3\% [46]. Estos valores tan elevados tienen su explicación en una elevada diversidad de raza, clima y costumbres, en una estructura del sistema de salud insuficiente, y en un nivel sociocultural tan variado con altos niveles de pobreza. En consecuencia, la incidencia de la hipertensión varía de una ciudad a otra; en Bogotá y Medellín es del $16,1 \%$ mientras que, en las regiones de Cali y Chocó, con mayor asentamiento de raza de color negro, es de $26,2 \%$ [47].

La hipertensión es un trastorno complejo que involucra varios sistemas de órganos. El avance en el conocimiento de los mecanismos implicados en la modulación de la presión arterial, la homeostasis de electrolitos, en la regulación de la función y la estructura vascular, identifica la generación de especies reactivas de oxígeno, particularmente del anión superóxido y el peróxido de hidrógeno, como uno de los factores clave [48]. A continuación, se identifican los principales mecanismos implicados:

- El estrés oxidativo o desequilibrio entre oxidantes y antioxidantes es una de las principales causas de la hipertensión arterial. Este desequilibrio podría desencadenar una producción excesiva de radicales libres y en consecuencia una respuesta inflamatoria que provocara daño en las células endoteliales, alterara el equilibrio del óxido nítrico en el endotelio, y elevara la producción de colesterol y lipoproteínas de baja densidad. 
- De forma similar al estrés oxidativo, la inflamación juega un papel importante en la fisiopatología de la hipertensión arterial en la que se observan marcadores inflamatorios endoteliales elevados como la proteína $C$, el óxido nítrico inducible, la endotelina-1, citoquininas como IL-1 $\beta, 6$, TNF- $\alpha$ y NF-kB.

- El sistema renina-angiotensina es uno de los sistemas fundamentales que regula la hipertensión en diferentes condiciones, ayudando a regular la presión sanguínea y el volumen extracelular y corporal [39].

Diferentes estudios ponen de manifiesto que muchos alimentos de la dieta pueden contribuir a reducir la hipertensión arterial. El control de la hipertensión con una dieta adecuada resulta especialmente relevante en los países de ingresos bajos donde el acceso a los tratamientos farmacológicos es limitado y costoso. Los componentes de los alimentos con actividad antioxidante, y específicamente aquellos que actúan como inhibidores de la enzima convertidora de la angiotensina, se consideran importantes para la prevención y el tratamiento de la hipertensión [49]. En este sentido, debe aumentar el consumo de frutas y verduras con elevado contenido en antioxidantes naturales [50]. El National Heart, Lung, and Blood Institute y también la American Heart Association establecieron unas pautas dietéticas dirigidas a la reducción de la hipertensión (Dietary Approaches to Stop Hypertension) y que incluyen una menor ingesta de sodio, azúcares y grasa, y un aumento en el consumo de frutas y verduras. Todos los agentes implicados en el sistema alimentario, desde el productor hasta el distribuidor y en especial la industria alimentaria, deben afrontar el reto de favorecer el consumo de alimentos naturales como las frutas y hortalizas. Los productos transformados obtenidos a partir de frutas $\mathrm{y}$ hortalizas, que tengan un adecuado contenido en antioxidantes y específicamente en componentes bioactivos con efecto positivo sobre la hipertensión, son también una alternativa [51].

\subsubsection{La malnutrición}

Hoy en día, prevenir y aliviar el hambre oculta, la malnutrición, la desnutrición, el sobrepeso y la obesidad, y en general la inseguridad alimentaria, es una preocupación en todo el mundo. Se estima que, 
aproximadamente, entre la mitad y dos tercios de la población mundial moderna padece al menos una deficiencia nutricional [4].

La malnutrición se define como un conjunto de trastornos metabólicos que se dan a causa de deficiencias de macronutrientes y/o micronutrientes o bien debido a la ingesta excesiva de estos (Cuenca et al., 2020). La OMS se refiere a deficiencias, excesos o desequilibrios de la ingesta de energía y/o nutrientes de una persona. El término engloba la desnutrición, que se manifiesta como inanición, retraso del crecimiento, deficiencias de micronutrientes (también llamada hambre oculta) y también el sobrepeso y la obesidad [52,53]. La FAO define la malnutrición como una condición fisiológica anormal causada por un consumo inadecuado, desequilibrado o excesivo de macronutrientes y/o micronutrientes [54]. La malnutrición es una enfermedad crónica que se desarrolla a partir de la interacción de factores genéticos, ambientales y socioeconómicos.

Disminuir la malnutrición es una de las principales prioridades de los Objetivos de Desarrollo Sostenible de las Naciones Unidas, en los que se establece erradicar el hambre y la malnutrición en 2030. Sin embargo, según los informes de la OMS y el Fondo de las Naciones Unidas para la Infancia son aspiraciones no alcanzables. Según el informe de la Organización de las Naciones Unidas para la Alimentación y la Agricultura, en la última edición sobre la seguridad alimentaria y la nutrición de 2021, la malnutrición afecta a una de cada tres personas en el mundo; el $45 \%$ de las muertes que se presentan a nivel mundial están vinculadas a la malnutrición; más de 690 millones de personas padecen subalimentación; alrededor de 149,2 millones de niños sufren retraso en el crecimiento; unos 45,4 millones de niños sufren inanición; y más de 770 millones de personas estuvieron expuestas a niveles altos de inseguridad alimentaria, sin contar con las consecuencias de la pandemia COVID-19, que ha aumentado las desigualdades en los países de ingresos bajos y medios $[52,54]$.

Abordar el desafío que supone erradicar la malnutrición en niños pequeños de 2 a 5 años y mujeres, es esencial para asegurar un crecimiento y desarrollo cognitivo óptimo y una buena salud en general. Algunos estudios han demostrado que la malnutrición en la primera infancia es irreversible [55]. Puede afectar el crecimiento e impedir que los niños alcancen una estatura y peso adecuado a su edad, y también puede tener efectos a largo plazo, como un rendimiento escolar deficiente y un sistema inmunológico débil. La 
lactancia materna subóptima, la deficiencia de vitamina $A$, de hierro, folato, vitamina $D$, calcio y vitamina $B_{12}$, y también la introducción de los alimentos complementarios en cantidad y calidad inadecuados, contribuyen a la malnutrición en la infancia, provocando un crecimiento físico deficiente, anemia, enfermedad inflamatoria intestinal, diabetes, pancreatitis crónica, enfermedades cardiovasculares, enfermedad pulmonar obstructiva crónica, insuficiencia renal crónica así como un inadecuado desarrollo psicomotor [37].

Hace aproximadamente 50 años, la malnutrición era un problema de los pobres, pero ahora se evidencia también en los países desarrollados. Todos los países, independientemente de su nivel de desarrollo económico, se enfrentan a una o más formas de malnutrición. La lucha contra la malnutrición es uno de los grandes desafíos sanitarios que afronta todo el mundo. Aunque las tres curtas partes de los niños con malnutrición se encuentran en África y Asia, la malnutrición infantil en América Latina constituye uno de los problemas más importante de salud pública, siendo uno de los grandes desafíos de los gobiernos en los próximos años [56].

Según la OMS, la Organización Panamericana de la Salud (OPS), el Banco Mundial, el Fondo de las Naciones Unidad para la Infancia (FNUI), la Organización de las Naciones Unidas para la Alimentación y la Agricultura (FAO) y el Programa Mundial de Alimentos, (WFP), en 2020 en América Latina y el Caribe, unos 47,7\% millones de personas padecen hambre [5]. Además, de acuerdo con las proyecciones realizadas en el informe sobre el Panorama de la Seguridad Alimentaria y Nutricional para América Latina y el Caribe, el número de personas subalimentadas aumentará a 67 millones en 2030, sin contar con las consecuencias generadas por la pandemia COVID-19. Si tenemos en cuenta la distribución por subregiones de América Latina, la mayor parte de la población subalimentada se evidencia en la Sudamérica con 24 millones, seguida por Mesoamérica con 16,6 millones y el Caribe con 7,8 millones de personas. En ese mismo informe, se destaca la malnutrición infantil como uno de los grandes problemas de salud en estas regiones. Aunque el proceso de erradicar la malnutrición ha avanzando en las dos últimas décadas, todavía esta muy por encima de las cifras mundiales. Además, hay que tener en cuenta que los datos suministrados en algunos países no reflejan la realidad y ocultan con frecuencia las situaciones reales de la población. 
Se estima que en los Estados Unidos el coste de la malnutrición es de 49 mil millones de dólares al año, para Europa el coste es de 120 mil millones de euros al año y en América Latina el coste es de 10,19 mil millones de personas. En 2015, la Academia de Nutrición y Dietética de siete países de diferentes partes del mundo, se reunieron con el objetivo de identificar estrategias orientadas a disminuir las carencias nutricionales. En 2019, se llevó a cabo un foro posterior en Cracovia- Polonia, convocado nuevamente por la Academia de Nutrición y Dietética, de países de Asia, Europa, América del Norte y América Latina. Dicho foro, todos los países convocados tenían como objetivo fundamental mejorar los resultados en salud relacionados con la malnutrición y especialmente en las poblaciones vulnerables. Se estableció la necesidad de cambiar el sistema alimentario en relación a cómo producimos y qué alimentos consumimos. Los responsables políticos y los profesionales deben trabajar juntos para garantizar que la industria alimentaria respalde la nutrición y la salud promocionando las dietas saludables y garantizando que los alimentos nutritivos sean asequibles. Según la FAO, se estima que 3 millones de personas no pueden acceder a una dieta saludable, pero una buena alimentación antes de la concepción, durante el embarazo y la lactancia reduce el riesgo de retraso en el crecimiento, obesidad y enfermedades crónicas no trasmisibles y enfermedades asociadas a la malnutrición [54,57].

\subsection{Compuestos bioactivos de interés en el tratamiento de la obesidad y/o hipertensión}

La fibra dietética se encuentra en los alimentos de origen vegetal, y químicamente comprende polímeros de carbohidratos (diez a más unidades monoméricas) que resisten la hidrólisis por las enzimas digestivas en el intestino delgado, pero pueden ser fermentadas por la microbiota del intestino grueso. La fibra se puede clasificar en soluble e insoluble; la soluble incluye fundamentalmente, pectina, inulina, algunas gomas, $\beta$-glucanos y algunos polisacáridos solubles; la insoluble incluye celulosa, hemicelulosa, lignina y almidón resistente [58]. La fibra soluble aporta mayor viscosidad que la fibra insoluble tanto en los alimentos en los que se encuentra como en el tracto gastrointestinal.

En varios estudios se ha verificado que una mayor ingesta de fibra dietética está relacionada con una menor prevalencia de enfermedades cardiovasculares, así como un menor riesgo de hipertensión, diabetes y 
obesidad [1,59]. El consumo de fibra retarda y/o disminuye la liberación de energía en una dieta excesiva mediante diferentes mecanismos: ralentiza el proceso de digestión, inhibe la absorción de macronutrientes en la superficie intestinal debido a que establece interacciones con algunos componentes y los insolubiliza, tiene una elevada capacidad para retener agua aumentando la sensación de saciedad. Otros estudios muestran los beneficios de la fermentación de la fibra insoluble en el colon. Esta fermentación origina, entre otros metabolitos, ácidos grasos de cadena corta (acetato, propionato y butirato), cada uno de los cuales ejerce efectos fisiológicos favorables y únicos [60]. A algunos componentes de la fibra se les confiere efecto prebiótico debido a que ejercen un efecto favorable sobre la microbiota intestinal. La fibra prebiótica se caracteriza por la resistencia a la digestión y la fermentación parcial o completa en el colon, estimulando el crecimiento de aquellas especies microbianas con efecto beneficioso en la salud. Hasta el momento únicamente la inulina y los trans-galacto-oligosacáridos han sido aceptados como prebióticos.

Los ácidos grasos monoinsaturados (MUFA) o poliinsaturados (PUFA) omega-3 y omega- 6 representan uno de los tipos más importantes de lípidos bioactivos que reciben en las últimas décadas mayor atención, tanto en términos cuantitativos como cualitativos [61]. Varios estudios epidemiológicos han evaluado la asociación entre el riesgo de síndrome metabólico y la dieta, específicamente la ingesta de ácidos grasos poliinsaturados. Se ha visto que los ácidos grasos omega-3 tienen un efecto beneficioso sobre el contenido de triglicéridos, azúcar en sangre, el colesterol unido a lipoproteínas de alta densidad (DHL) y la resistencia a la insulina. De manera similar, los omega- 6 reducen el riesgo de diabetes tipo 2 , reducen el colesterol total y aumentan el colesterol DHL [62]. Los ácidos grasos monoinsaturados han resultado efectivos en la disminución del riesgo de enfermedades cardiovasculares y reducción del colesterol asociado a las proteínas de baja densidad en el torrente sanguíneo [63]. En general los ácidos grasos insaturados podrían considerarse útiles para combatir el síndrome metabólico [64,65].

Las vitaminas $\mathrm{E}$ y $\mathrm{C}$ actúan como antioxidantes disminuyendo el estrés oxidativo y el riesgo vascular. La vitamina $\mathrm{E}$ es una de las vitaminas liposolubles que está presente en la membrana biológica actuando en la primera defensa contra la peroxidación lipídica, y, por tanto, evitando el daño oxidativo a los 
tejidos y órganos del cuerpo humano. En su estudio reciente, Lui et al. [66], han mostrado que la vitamina $\mathrm{E}$, no solo es capaz de proteger la autooxidación de los ácidos grasos poliinsaturados y mejorar la función inmunológica humana, sino que juega un papel importante en la prevención de enfermedades cardiovasculares y otras enfermedades relacionadas. Varios estudios in vitro e in vivo en modelos animales y humanos en condiciones normales y patológicas han demostrado sus efectos cardioprotectores, antioxidantes y antiinflamatorios contra la hipertensión y la obesidad $[67,68]$.

La vitamina $\mathbf{C}$ es un potente antioxidante abundante en frutas y hortalizas frescas. Algunos estudios han revelado que la vitamina $C$ en concentraciones bajas, disminuye el estrés oxidativo y participa como factor principal en la modulación del metabolismo de los lípidos [69]. En algunos estudios, se ha planteado la hipótesis de que una ingesta adecuada de vitamina C mejora la endotoxemia y por consiguientes la respuesta proinflamatoria relacionada con la resistencia a la insulina y los trastornos metabólicos [70].

Los péptidos bioactivos son secuencias cortas de 2 a 50 aminoácidos que ejercen efectos fisiológicos; pueden absorberse en el intestino y circular por el torrente sanguíneo. Los péptidos pueden generarse mediante proteólisis in vitro, síntesis química o también durante las etapas de procesado (incluida la fermentación con bacterias ácido-lácticas) y digestión gastrointestinal de los alimentos. Hay una amplia variedad de péptidos bioactivos y se pueden dividir en endógenos y exógenos; los péptidos endógenos se obtienen por hidrólisis de las proteínas con endopeptidasas, y los péptidos exógenos mediante hidrólisis con exopeptidasas [71]. Durante la última década, se ha generado interés en el descubrimiento de péptidos bioactivos derivados de proteínas alimentarias. Recientemente, se les ha atribuido actividad antioxidante, y actividad potencial para regular la hipertensión arterial, reducir el nivel de colesterol y la masa corporal en el caso de la obesidad. Además, algunos péptidos proporcionan efecto de saciedad provocando la disminución del apetito [72,73].

Los aminoácidos esenciales también han sido considerados en los últimos años como componentes bioactivos con un efecto beneficioso sobre la salud. Se ha demostrado que las concentraciones elevadas de aminoácidos de cadena ramificada (isoleucina y leucina) y la concentración reducida de glicina (alifática) son marcadores prediabetes y resisten a la insulina. También, 
se ha demostrado que los aminoácidos aromáticos (fenilalanina, triptófano y histidina), están asociados con una disminución de la hipertensión y la obesidad [74]. Los efectos potenciales de los aminoácidos sobre la salud y las enfermedades cardiovasculares se han atribuido a la modulación del metabolismo del óxido nítrico, la insulina y la homeostasis de la glucosa.

Otros componentes bioactivos que se sospecha que desempeñan un papel importante en la salud humana y prevención de enfermedades son los minerales. Sin embargo, no hay suficientes estudios para describir claramente sus funciones y/o cantidades necesarias [75]. Algunos minerales que se sabe que son esenciales, incluyen el calcio, el magnesio, el fósforo, el azufre, el cloro, el potasio y el calcio. Otros, considerados esenciales en cantidades muchas más pequeñas, incluyen el hierro, el cobalto, el níquel, el cobre, el zinc, el selenio, el bromo y el yodo.

Números estudios en las últimas décadas han demostrado, de manera concluyente, que los minerales juegan un papel importante en la prevención y tratamiento del síndrome metabólico. A continuación, describiremos algunos efectos del magnesio, el calcio y el zinc por ser los que tienen una mayor implicación en los desórdenes considerados en esta tesis doctoral. El magnesio y el calcio cumplen una función estructural, además de actuar como electrolitos. Además de contribuir a la formación estructural de los huesos y los dientes, el calcio es necesario para el adecuado funcionamiento de los sistemas endocrino, neurológico, muscular y cardiovascular. También, se ha reconocido como un factor en la regulación de la hipertensión arterial. Numerosos estudios experimentales han demostrado que puede reducir la hipertensión. Billington et al. [76], mostraron, en un estudio con suplementación de calcio, que redujo significativamente la presión arterial sistólica. Los mecanismos por los que el calcio puede ejercer un efecto beneficioso sobre la presión incluyen el efecto sobre los niveles de vitamina $D$ y la parathormona, provocando la relajación de las células del músculo liso y la resistencia vascular periférica.

El magnesio es un electrolito esencial para los organismos vivos y el cuarto mineral más abundante en el cuerpo humano. El tracto gastrointestinal, los huesos y los riñones son los principales reguladores de la homeostasis del magnesio [77]. Una revisión sistemática y un metaanálisis revelaron que la suplementación con magnesio reduce el riesgo cardiovascular [78]. Del mismo modo, se ha demostrado que la 
suplementación con magnesio en dosis superior a $300 \mathrm{mg} /$ día disminuye significativamente la hipertensión arterial [79]. También, se ha demostrado que el magnesio juega un papel importante en el control de los niveles de glucosa en personas con diabetes, debido a que la hipomagnesia puede provocar resistencia a la insulina.

El zinc y el magnesio tienen efectos directos e indirectos sobre el desarrollo de resistencia a la insulina. La deficiencia de zinc o magnesio puede predisponer a un individuo a la intolerancia a la glucosa, resistencia a la insulina y diabetes mellitus. El magnesio también juega un papel como antioxidante y puede reducir la inflamación crónica, como el zinc [80].

Los fitoquímicos son compuestos bioactivos no nutritivos de las plantas, que más allá de proporcionar a las plantas color, olor y sabor, pueden tener efectos beneficiosos para salud. Los principales fitoquímicos en investigación incluyen los carotenoides ( $\alpha$-caroteno, $\beta$-caroteno, $\beta$ criptoxantina, licopeno, luteína, y zeaxantina); flavonoides como las flavonas (fisetina y apigenina), flavonoles (quercetina, kaempferol y gingerol), flavanoles (catequina, galato y epigalocatequina), isoflavonoides (genisteína) y antocianidinas; los ácidos fénolicos; y los estilbenos (resveratrol). Estos compuestos biológicamente activos, han ganado interés en los últimos años debido a su importante papel antioxidante y su efecto positivo en enfermedades relacionadas con el cáncer, obesidad, colesterol, diabetes tipo 2 y la hipertensión arterial [81]. Recientemente, se ha prestado mucha atención al efecto de los flavonoides sobre la obesidad y los trastornos metabólicos asociados. Se ha revelado que pueden inducir la hidrólisis de lípidos neutrales de los depósitos de lípidos en los tejidos adiposo y el hígado. También, inhiben el trasporte intestinal de glucosa y fructosa. De hecho, las catequinas y antocianinas reducen significativamente el peso de los tejidos adiposos; el ácido gálico reduce la proliferación de preadipocitos mediante inducción de la apoptosis celular; el ácido cafeico y el ácido clorogénico pueden controlar la adipogénesis al promover la lipólisis y la apoptosis de los adipocitos [82]. La quercetina se considera inhibidor de enzimas productoras de inflamación como la ciclooxigenasa y la lipoxigenasa, del factor de necrosis tumoral $\alpha$ (TNF- $\alpha$ ), de interleuquinas proinflamatorias como la IL-1, -6 y -8 t y de la peroxidación de lípidos [39,83].

Debido al interés sobre el efecto en la obesidad e hipertensión que los compuestos bioactivos han despertado, en los últimos años se han realizado 
multitud de estudios in vitro e in vivo (animales y humanos) que tratan de dar luz a estos efectos. En la siguiente tabla (tabla 1.2) se resumen algunos de los más importantes.

Tabla 1.2. Recopilación de estudios que muestran algunos compuestos bioactivos y su efecto probado sobre la obesidad e hipertensión.

\begin{tabular}{|c|c|c|c|}
\hline Fitoquímicos & Metodología & Resultados clave & Referencia \\
\hline $\begin{array}{l}\text { Flavonoides (quercitrina, } \\
\text { isoquercitrina y afzelina) } \\
\text { aislados de } \text { Acer } \\
\text { okamotoanum }\end{array}$ & $\begin{array}{c}\text { Células 3T3-L1 y flavonoides } \\
\text { a diferentes } \\
\text { concentraciones: } 1-10 \\
\mu \mathrm{g} / \mathrm{mL}\end{array}$ & $\begin{array}{l}\text { Disminución de los factores de } \\
\text { transcripción adipogénicos e } \\
\text { inhibición de las expresiones de } \\
\text { proteínas relacionadas con la } \\
\text { lipogénesis y la señalización de } \\
\text { AMPK }\end{array}$ & {$[84]$} \\
\hline Phyllanthus emblica L. & $\begin{array}{c}\text { Células } 3 T 3-\mathrm{L} 1 \text { con } \\
\text { diferentes concentraciones } \\
0,10,25,50,100 \text { y } 200 \\
\mu \mathrm{g} / \mathrm{mL} \text { ) y ácido digálico }(0, \\
2,5,5,10,25 \text { y } 50 \mu \mathrm{g} / \mathrm{mL}) \\
\text { durante } 3 \text { días }\end{array}$ & $\begin{array}{c}\text { Disminución de la acumulación de } \\
\text { triglicéridos y regula la baja } \\
\text { adiponectina, PPAR }, \mathrm{C} \text { / EBP } \alpha \text { y } \\
\text { FABP4 }\end{array}$ & {$[85]$} \\
\hline Pelargonidina & $\begin{array}{l}\text { Células 3T3-L1 a diferentes } \\
\text { concentraciones }(5,10,20, \\
\text { 50, 100, } 200 \mu \mathrm{M}) \text { de } \\
\text { pelargonidina }\end{array}$ & $\begin{array}{l}\text { Vía de señalización inhibida de } \\
\qquad \text { PPAR- } \gamma\end{array}$ & {$[86]$} \\
\hline Resveratrol & Células L6 parentales & $\begin{array}{c}\text { Aumento de la señalización de la } \\
\text { insulina, los niveles de membrana } \\
\text { plasmática GLUT4 y la captación de } \\
\text { glucosa }\end{array}$ & [87] \\
\hline Curcumina & $\begin{array}{c}\text { Las células 3T3-L1 y } \\
\text { Curcumina a diferentes } \\
\text { dosis: } 0-50 \mu \mathrm{M} \text { durante } 24 \text {, } \\
48 \text { y } 72 \mathrm{~h}\end{array}$ & $\begin{array}{c}\text { Expresión de PPARy y C / EBPa fue } \\
\text { regulada negativamente, así como } \\
\text { la disminución de la acumulación } \\
\text { de lípidos }\end{array}$ & {$[88]$} \\
\hline Kaempferol & $\begin{array}{c}\text { Las células 3T3-L1 y } \\
\text { concentraciones de } \\
\text { kaempferol: } 20,40,60,80 \text {, } \\
\text { 100, 120, 150, } 170 \mu \mathrm{M} \\
\text { durante } 24,48, \text { y } 72 \mathrm{~h}\end{array}$ & $\begin{array}{c}\text { Preadipocitos: inhibición de la } \\
\text { adipogénesis (62\%);adipocitos } \\
\text { maduros: acumulación de lípidos } \\
\text { intracelulares (39\%) }\end{array}$ & [89] \\
\hline $\begin{array}{c}\text { Crocin, ácido clorogénico, } \\
\text { el genipósido, y la } \\
\text { quercetina }\end{array}$ & $\begin{array}{l}\text { Células HepG2 y } \\
\text { concentraciones de crocina } \\
\text { de } 1 \mu \mathrm{mol} / \mathrm{L} \text {, ácido } \\
\text { clorogénico de } 30 \mu \mathrm{mol} / \mathrm{L} \text {, } \\
\text { genipósido } 10 \mu \mathrm{mol} / \mathrm{L} \text {, y } \\
\text { quercetina } 10 \mu \mathrm{mol} / \mathrm{L}\end{array}$ & $\begin{array}{l}\text { Disminución de los niveles de } \\
\text { triglicéridos y colesterol total }\end{array}$ & {$[90]$} \\
\hline Hispidulina & $\begin{array}{c}\text { Células } 3 T 3-L 1 \text { y hispidulina } \\
\text { con concentraciones de } 0 \text { a } \\
40 \mu \mathrm{M} \text { durante } 24 \mathrm{~h}\end{array}$ & $\begin{array}{l}\text { Disminución y diferenciación } \\
\text { suprimida de adipocitos, } \\
\text { acumulación de lípidos } \\
\text { celulares; reducción de la } \\
\text { expresión de ARNm y proteínas de } \\
\text { PPARY y adiponectina }\end{array}$ & {$[91]$} \\
\hline
\end{tabular}


Introducción

\begin{tabular}{|c|c|c|c|}
\hline $\begin{array}{l}\text { Extracto de té verde con } \\
\text { disulfuro de dialilo (DADS) }\end{array}$ & $\begin{array}{c}\text { Ratones alimentados con } \\
\text { dieta alta en grasa y } \\
\text { sacarosa suplementados } \\
\text { con } 0,1 \% \text { de extracto de } \mathrm{GT} \\
\text { y } 2 \mathrm{mg} \text { de peso corporal de } \\
\text { DADS }\end{array}$ & $\begin{array}{l}\text { Suprimió la regulación positiva de } \\
\text { SREBP-1, del ácido graso sintasa y } \\
\text { de la estearoil-CoA desaturasa-1 }\end{array}$ & [92] \\
\hline Catequinas de té verde & $\begin{array}{c}\text { Ratones: tratamiento con } \\
\text { dosis del } 0 \% \text { y } 2 \% \text { durante } 8 \\
\text { semanas }\end{array}$ & $\begin{array}{c}\text { Disminución de inflamación } \\
\text { intestinal NFKB en tejido adiposo y } \\
\text { translocación de endotoxinas para } \\
\text { combatir la obesidad }\end{array}$ & [93] \\
\hline $\begin{array}{l}\text { La epigalocatequina-3- } \\
\text { galato }\end{array}$ & $\begin{array}{c}\text { Ratones alimentadas con } \\
\text { dietas altas en grasa y } \\
\text { suplementados en dosis de } \\
50 \text { y } 100 \mathrm{mg} / \mathrm{kg} \text { día durante } \\
20 \text { semanas }\end{array}$ & $\begin{array}{c}\text { Diminución moderada del peso } \\
\text { corporal y del índice de tejido } \\
\text { adiposo subcutáneo }\end{array}$ & [94] \\
\hline Naringenina & $\begin{array}{c}\text { Ratas y ratones alimentados } \\
\text { con } 10 \mathrm{~m} / \mathrm{kg} \text { por sonda oral } \\
\text { por día durante } 4 \text { semanas, } \\
0,1 \% \text { en dieta experimental } \\
\text { durante } 6 \text { meses, } 1 \% \text { y } 3 \% \\
\text { en una dieta alta en grasas } \\
\text { durante } 4 \text { y } 30 \text { semanas }\end{array}$ & $\begin{array}{l}\text { Actividad antioxidante, Resistencia } \\
\text { a la insulina y actividades } \\
\text { antioxiante, antiobesidad, } \\
\text { antihiperglucémica, antidiabética, } \\
\text { antiinflamatoria, antihipertensiva y } \\
\text { cardioprotectora. }\end{array}$ & [95] \\
\hline Apigenina & $\begin{array}{l}\text { Ratones alimentados con } 50 \\
\mathrm{mg} / \mathrm{kg} \text { día por sonda oral } \\
\text { durante } 4 \text { semanas }\end{array}$ & $\begin{array}{c}\text { Resistencia a la insulina atenuada, } \\
\text { dislipidemia y daño hepático y } \\
\text { estrés oxidativo de la vía Keap1 a } \\
\text { Nrf2 }\end{array}$ & [96] \\
\hline $\begin{array}{l}\text { Extracto Plinia jaboticaba } \\
\text { rico en elagitaninos, } \\
\text { proantocianidinas y } \\
\text { antocianos }\end{array}$ & $\begin{array}{l}\text { Ratones alimentados con } \\
\text { dietas altas en grasa y } \\
\text { sacarosa y suplementados } \\
\text { con concentración baja y } \\
\text { alta de taninos del extracto } \\
\text { con dosis de } 50 \mathrm{mg} / \mathrm{GEA} \\
\text { día durante } 8 \text { semanas }\end{array}$ & $\begin{array}{l}\text { Extracto alto: disminución del peso } \\
\text { corporal, atenuación de la } \\
\text { hiperglucemia, la hiperinsulinemia, } \\
\text { los niveles de colesterol y } \\
\text { triacilgliceroles hepáticos }\end{array}$ & [97] \\
\hline $\begin{array}{l}\text { Extracto de semilla de } \\
\text { girasol (Helianthus } \\
\text { annuus) }\end{array}$ & $\begin{array}{c}\text { Dieta: } 500 \mathrm{mg} \text { de extracto } \\
\text { de girasol ( } 40 \% \text { de ácido } \\
\text { clorogénico) por día durante } \\
12 \text { semanas }\end{array}$ & $\begin{array}{l}\text { Reducción del peso corporal, la } \\
\text { grasa corporal, el IMC, la } \\
\text { circunferencia de la cintura y los } \\
\text { niveles de colesterol }\end{array}$ & [98] \\
\hline Extracto de arándano & $\begin{array}{l}\text { Consumo de } 450 \mathrm{~mL} \text { de } \\
\text { bebida de extracto de } \\
\text { arándano bajo en calorías y } \\
\text { alto contenido de } \\
\text { polifenoles al día durante } 8 \\
\text { semanas }\end{array}$ & $\begin{array}{l}\text { Mejora del estado antioxidante } \\
\text { (aumento de GSH, SOD) e } \\
\text { inflamatorio (disminución de } \\
\text { proteína C reactiva), } \\
\text { glucorregulación (disminución de } \\
\text { insulina) y mejora del perfil lipídico } \\
\text { (aumento de HDL) }\end{array}$ & [99] \\
\hline Zumo de naranja & $\begin{array}{c}\text { Dieta: } 500 \mathrm{~mL} / \text { día de zumo } \\
\text { de naranja durante } 12 \\
\text { semanas }\end{array}$ & $\begin{array}{l}\text { Disminución de la glucemia y la } \\
\text { resistencia a la insulina, reducción } \\
\text { del colesterol total y del C-LDL }\end{array}$ & {$[100]$} \\
\hline $\begin{array}{l}\text { Cáscara de manzana rica } \\
\text { en polifenoles }\end{array}$ & $\begin{array}{l}\text { Dieta alta en grasas (HFD) } \\
\text { suplementada con } \\
\text { concentraciones de } 10 \text { o } \\
20 \% \text { de cáscara de manzana } \\
\text { durante } 4 \text { semanas }\end{array}$ & $\begin{array}{l}\text { Ningún cambio significativo en el } \\
\text { peso corporal; influencia del } \\
\text { microbiana y biodisponibilidad de } \\
\text { polifenoles }\end{array}$ & [101] \\
\hline
\end{tabular}




\begin{tabular}{|c|c|c|c|}
\hline Pistachos & $\begin{array}{l}\text { Dieta alta en grasas (HFD) } \\
\text { con pistacho ( } 180 \mathrm{~g} / \mathrm{kg} \text { de } \\
\text { HFD) durante } 16 \text { semanas }\end{array}$ & $\begin{array}{l}\text { Reducción del colesterol, masa de } \\
\text { grasa corporal y tamaño de los } \\
\text { adipocitos, así como normalización } \\
\text { de la expresión de genes } \\
\text { relacionados con el metabolismo } \\
\text { de los lípidos (p. Ej., PPAR- } ү \text { o } \\
\text { SREBP-1c) }\end{array}$ & {$[102]$} \\
\hline Extracto de té verde & $\begin{array}{l}\text { Consumo diario durante } 6 \\
\text { semanas de extractos con } \\
\text { EGCG (856,8 mg/dosis) y } \\
\text { ECG (236,1 mg/dosis) }\end{array}$ & Niveles reducidos de LDL y leptina & {$[103]$} \\
\hline $\begin{array}{l}\text { Extractos de Moringa } \\
\text { oleifera, Murraya } \\
\text { koeingii, Curcuma longa }\end{array}$ & $\begin{array}{l}\text { Consumo diario de dosis de } \\
900 \mathrm{mg} \text { de extracto de } \\
\text { moringa durante } 16 \\
\text { semanas }\end{array}$ & $\begin{array}{l}\text { Reducción del peso corporal, índice } \\
\text { de masa corporal y perfil lipídico } \\
\text { mejorado (relación LDL/HDL) }\end{array}$ & [104] \\
\hline $\begin{array}{c}\text { Extractos de cagaita } \\
\text { (Eugenia dysenterica DC.) }\end{array}$ & $\begin{array}{l}\text { Dieta alta en grasa durante } \\
6 \text { semanas con dos dosis de } \\
7 \mathrm{mg} \text { de equivalente de } \\
\text { ácido gálico (GAE)/kg de } \\
\text { peso corporal }\end{array}$ & $\begin{array}{l}\text { Mejora la homeostasis de la } \\
\text { glucosa, atenúa la dislipidemia y } \\
\text { reduce la inflamación hepática sin } \\
\text { afectar el peso corporal y la } \\
\text { adiposidad }\end{array}$ & {$[27]$} \\
\hline $\begin{array}{l}\text { Jugo y naranja sanguina, } \\
\text { jugo de granada, té verde, } \\
\text { puré y manzana Renetta } \\
\text { (polifenoles) }\end{array}$ & $\begin{array}{l}\text { Ensayo de intervención } \\
\text { cruzado, controlado y } \\
\text { aleatorizado con } 62 \\
\text { participantes ( } 27 \text { hombres y } \\
39 \text { mujeres) con dosis de } \\
700 \text { mg de polifenoles } \\
\text { durante } 6 \text { semanas }\end{array}$ & $\begin{array}{l}\text { Reducción de la hipertensión } \\
\text { arterial }\end{array}$ & {$[105]$} \\
\hline Catequinas de té verde & $\begin{array}{l}\text { Participaron } 921 \text { sujetos } \\
\text { ( } 505 \text { hombres y } 416 \\
\text { mujeres) con dosis de } 540 \\
\text { mg/ día y } 588 \mathrm{mg} / \text { día }\end{array}$ & $\begin{array}{c}\text { Ingesta con Catequinas redujo peso } \\
\text { corporal y el área de grasa } \\
\text { abdominal, mejora la presión } \\
\text { arterial y el estado del síndrome } \\
\text { metabólico }\end{array}$ & {$[106]$} \\
\hline $\begin{array}{l}\text { Zumo de uva (Isabel, } \\
\text { Bordeaux y Concord) } \\
\text { Polifenoles }\end{array}$ & $\begin{array}{c}\text { Participaron } 28 \text { sujetos, } 23 \\
\text { hombres y } 5 \text { mujeres } \\
\text { consumieron } 10 \mathrm{~mL} / \mathrm{kg} \text { en } \\
\text { dos dosis por día durante } 28 \\
\text { días }\end{array}$ & $\begin{array}{l}\text { Reducción de la presión arterial, el } \\
\text { colesterol total y LDL aumento y } \\
\text { mejoró el estado antioxidante y el } \\
\text { perfil cardiometabólico }\end{array}$ & [107] \\
\hline $\begin{array}{c}\text { Zumo de granada } \\
\text { Punicalagina y ácido } \\
\text { elágico }\end{array}$ & $\begin{array}{l}\text { Medición de la lipólisis y } \\
\text { lipogénesis en el tejido } \\
\text { adiposo }\end{array}$ & $\begin{array}{l}\text { Prevención del síndrome } \\
\text { metabólico }\end{array}$ & [108] \\
\hline $\begin{array}{c}\text { Extracto de piel de } \\
\text { cebolla rico en quercetina }\end{array}$ & $\begin{array}{c}\text { Ensayo cruzado, doble } \\
\text { ciego, aleatorizado y } \\
\text { controlado con placebo } 68 \\
\text { sujetos ( } 34 \text { hombres y } 34 \\
\text { mujeres) dosis de } \\
\text { quercetina de } 162 \text { mg por } \\
\text { día durante } 6 \text { semanas }\end{array}$ & $\begin{array}{c}\text { Reducción de la hipertensión } \\
\text { arterial sin efecto en la actividad } \\
\text { de la enzima convertidora de } \\
\text { angiotensina, función endotelial, } \\
\text { parámetros de oxidación } \\
\text { inflamación y metabolismo de } \\
\text { lípidos y glucosa }\end{array}$ & [109] \\
\hline $\begin{array}{l}\text { Espermidina (de extracto } \\
\text { pulpa de lulo) }\end{array}$ & $\begin{array}{c}\text { Medición in vitro de la } \\
\text { inhibición de la enzima } \\
\text { convertidora de } \\
\text { angiotensina IC50 = 1,8 ppm }\end{array}$ & Control hipertensión & [110] \\
\hline
\end{tabular}




\subsubsection{Probioticos}

El concepto de probiótico fue desarrollado alrededor de 1900 por Elie Metchnikoff, quien descubrió que el consumo de microorganismo vivo del Lactobacillus bulgaricus en la leche materna y el yogur mejoraba algunas propiedades del tracto gastrointestinal [111]. El término probiótico ha sido definido por la Organización para la Alimentación y la Agricultura de las Naciones Unidas y la Organización Mundial de la Salud y revisado por la Asociación Internacional para la Ciencia de prebióticos y probióticos (ISAPP) [112]. Los probióticos son microorganismos vivos que, administrados en cantidades adecuadas, confieren un beneficio para la salud del huésped [113]. Según la Asociación Internacional para la Ciencia de prebióticos y probióticos (2018), para que un microorganismo pueda ser considerado como probiótico debe cumplir con información suficiente acerca de la designación de la cepa; debe haberse realizado el depósito de la cepa en una colección de cultivos internacional; y sus propiedades beneficiosas para la salud deben haber sido validadas por al menos un estudio en humanos[114].

Para poder ejercer un efecto beneficioso sobre la salud, los probióticos requieren una alta viabilidad y supervivencia en condiciones adversas en el tracto gastrointestinal, acción antagonista contra patógenos, estimulación del sistema inmunológico, efectos beneficiosos sobre la salud y deben mantener su eficacia cuando los alimentos que los contienen se someten a las operaciones de procesado [115]. Aunque, según la Organización Mundial de Gastroenterología [116] la dosis requerida del microorganismo probiótico depende de la cepa y del producto, diferentes estudios han demostrado que el número viable de supervivencia probiótica para que llegue a cumplir la función en el intestino debe ser al menos de $10^{6}-10^{7} \mathrm{UFC} / \mathrm{mL}$ o un total de $10^{8}-10^{9}$ UFC/día [114].

Entre los alimentos funcionales emergentes en el mercado, los alimentos y las bebidas con probióticos se consideran alimentos del futuro y tienen una gran aceptación entre los consumidores. El mercado global ascendió, aproximadamente, a 48,44 mil millones de dólares en 2019 y se espera que alcance los 98,48 mil millones de dólares en 2024. Estados Unidos y Asia dominan el mercado. Europa ha mostrado una tasa de crecimiento lenta y América Latina es uno de los segmentos con mayor previsión de mercado [117]. El uso de los probióticos en la industria farmacéutica y alimentaria es 
bastante versátil y los productos lácteos siguen siendo la forma más popular para el consumo. Sin embargo, otros alimentos a base de zumos de frutas están generando interés en el consumidor, aunque todavía representan una pequeña parte del mercado de los alimentos con probióticos [114].

Existen evidencias científicas de que los probióticos pueden prevenir ciertas enfermedades inflamatorias, enfermedades metabólicas, cánceres de colon y vejiga, infecciones agudas del tracto respiratorio y mejorar la intolerancia a la lactosa. Se han realizado multitud de ensayos clínicos en humanos utilizando probióticos para tratar o mejorar los síntomas de diferentes enfermedades como la obesidad, las enfermedades cardiovasculares, la diabetes y algunas reacciones alérgicas [118,119]. Cada vez hay más evidencias que han asociado el desarrollo y mantenimiento de la obesidad y la hipertensión con el cambio de la microbiota intestinal.

La microbiota intestinal se considera uno de los órganos más importantes del ser humano y está formado por billones de microorganismos y miles de especies que cumplen diferentes roles en el huésped. Influye en el metabolismo a través del equilibrio energético, la regulación de la inflamación y la barrera intestinal. Algunos informes sugieren que la microbiota intestinal no solo juega un papel importante en el metabolismo del huésped, sino que también desempeña un papel modulador de la obesidad, lo que siguiere que a través de la dieta $u$ otros medios puede conferir efectos beneficiosos al restaurar la integridad funcional del intestino[120].

Las últimas investigaciones han demostrado que al cambiar la composición de la microbiota intestinal, los probióticos producen un efecto positivo sobre las enfermedades metabólicas, como la obesidad y la diabetes tipo 2. Se han identificado como posibles mecanismos, la reducción del estrés oxidativo, el aumento de la secreción de incretinas y la expresión de proteínas de adhesión dentro del epitelio intestinal causando una reducción de la inflamación sistémica crónica [120,121]. En la tabla 1.3 se incluyen varios estudios clínicos en humanos y animales, realizados con diferentes cepas de probióticos. Se resumen sus efectos sobre los parámetros relacionados con los trastornos metabólicos, principalmente la obesidad y la hipertensión. 
Tabla 1.3. Recopilación de estudios que muestran algunos microorganismos probioticos y su efecto probado sobre la obesidad e hipertensión.

\begin{tabular}{|c|c|c|c|}
\hline Microrganismos & Metodología & Resultados clave & Referencia \\
\hline $\begin{array}{l}\text { Lactobacillus rhamnosus 4B15, } \\
\text { prebióticos en leche desnatada con } \\
\text { lactosa hidrolizada en polvo }\end{array}$ & $\begin{array}{l}\text { Ratones alimentados con } \\
\text { dietas con alto contenido } \\
\text { en grasa, suplementados } \\
\text { con } 10^{8} \mathrm{UFC} / \mathrm{Kg} \text { y leche } \\
\text { desnatada con lactosa } \\
\text { hidrolizada durante } 10 \\
\text { semanas }\end{array}$ & $\begin{array}{l}\text { Reducción de la grasa corporal, } \\
\text { el daño hepático y la expresión } \\
\text { de genes relacionados con la } \\
\text { síntesis de grasa y la } \\
\text { inflamación de las células } \\
\text { adiposas y hepáticas }\end{array}$ & [122] \\
\hline Lactobacillus fermentum CECT5716 & $\begin{array}{l}\text { Ratones alimentados con } \\
\text { dietas altas en grasa y } \\
\text { Lactobacillus fermentum } \\
\left(5 \cdot 10^{8} \text { UFC) }\right.\end{array}$ & $\begin{array}{l}\text { Reducción de la ganancia de } \\
\text { peso y la acumulación de tejido } \\
\text { graso. Mejoró la prueba de } \\
\text { tolerancia a la glucosa, el perfil } \\
\text { bioquímico del plasma, el } \\
\text { estado inflamatorio en los } \\
\text { tejidos metabólicos y la } \\
\text { función endotelial }\end{array}$ & [123] \\
\hline Bifidobacterium animalis 01 & $\begin{array}{l}\text { Ratones alimentados con } \\
\text { dietas suplementados con } \\
10^{9} \mathrm{UFC} / \mathrm{mL}\end{array}$ & $\begin{array}{l}\text { Reducción de los niveles } \\
\text { séricos YC, TG, LDL-C, LPS-TNF- } \\
\alpha \text {, del glucógeno hepático, } \\
\text { regulación de la expresión de } \\
\text { los genes relacionados con la } \\
\text { glucogénesis PEPCK y G6Pase } \\
\text { en el hígado. Mitiga los efectos } \\
\text { de la glucosa regulando la vía } \\
\text { IRS/PI3K/AKT y Keap1/Nrf2 }\end{array}$ & [124] \\
\hline Lactobacillus plantarum HT121 & $\begin{array}{l}\text { Ratones alimentados con } \\
\text { dietas altas en grasa con y } \\
\text { sin Lactobacillus plantarum } \\
10^{8} \text { UFC/mL durante } 11 \\
\text { semanas }\end{array}$ & $\begin{array}{l}\text { Reducción de la acumulación } \\
\text { de la grasa corporal, mejora del } \\
\text { nivel de los factores } \\
\text { inflamatorios LPS, TNF } \alpha, \text { IL-1 } \beta \text {, } \\
\text { y IL-6 y tolerancia a la glucosa }\end{array}$ & [125] \\
\hline Leuconostoc mesenteroides subsp & $\begin{array}{l}\text { Ratones alimentados con } \\
\text { dieta alta en grasa con una } \\
\text { dosis diaria de } 10^{10} \text { UFC/ } \\
\mathrm{mL} \text { durante } 14 \text { semanas }\end{array}$ & $\begin{array}{l}\text { Reducción del peso corporal, } \\
\text { niveles de glucosa, colesterol, } \\
\text { leptina y mejora de la } \\
\text { tolerancia a la glucosa, mejoría } \\
\text { de la esteatosis hepática, } \\
\text { número de adipocitos más } \\
\text { grandes en el tejido adiposo y } \\
\text { reducción de la altura de las } \\
\text { vellosidades en el intestino } \\
\text { delgado, disminución de la } \\
\text { expresión hepática de TNF- } \alpha \text { y } \\
\text { aumento de la expresión de IL- } \\
10\end{array}$ & [126] \\
\hline
\end{tabular}




\begin{tabular}{|c|c|c|c|}
\hline Lactobacillus plantarum A29 & $\begin{array}{l}\text { Ratones alimentados con } \\
\text { una dosis de } 10^{9} \mathrm{UFC} / \mathrm{g} \\
\text { diario y adipocitos in vitro } \\
\text { 3T3-L1 durante } 8 \text { semanas }\end{array}$ & $\begin{array}{l}\text { Reducción del peso corporal, } \\
\text { de la masa grasa y del perfil de } \\
\text { lípidos séricos. Regulación a la } \\
\text { baja de la expresión de genes } \\
\text { lipogénicos en los adipocitos, } \\
\text { activación de p38MAPK, } \\
\text { p44/42, y AMPK- } \alpha \\
\text { aumentando su fosforilación. } \\
\text { Los metabolitos derivados de } \\
\text { probióticos inhibieron la } \\
\text { diferenciación de los } \\
\text { adipocitos } 3 \text { T3-L1y las } \\
\text { deposiciones de grasa } \\
\text { mediante la regulación a la } \\
\text { baja de factores } \\
\text { transcripcionales adipogénicos } \\
\text { clave (PPAR- } \gamma \text {, C / EBP- } \alpha \text { y C / } \\
\text { EBP- } \beta \text { ) }\end{array}$ & [127] \\
\hline $\begin{array}{l}\text { Lactobacillus } \\
\text { pentosus GSSK2, Lactobacillus } \\
\text { fermentum PUM y Lactobacillus } \\
\text { plantarum GS26A }\end{array}$ & $\begin{array}{l}\text { Ratones alimentados con } \\
\text { dieta alta en grasa con L- } \\
\text { ornitina ( } 20 \mathrm{mg} / \mathrm{kg} \text { de peso } \\
\text { corporal por día) y dieta } \\
\text { alta en grasa con una dosis } \\
\text { de } 10^{9} \text { UFC por día durante } \\
12 \text { semanas }\end{array}$ & $\begin{array}{l}\text { Reducción del peso corporal, la } \\
\text { masa de tejido graso del } \\
\text { epidídimo y los niveles de } \\
\text { triglicéridos en suero y hígado, } \\
\text { citocinas séricas y niveles más } \\
\text { bajos de ARNm de citocinas } \\
\text { inflamatorias en el tejido } \\
\text { adiposo del epidídimo }\end{array}$ & [128] \\
\hline $\begin{array}{l}\text { Lactobacillus casei NCU011054, } \\
\text { Lactobacillus fermentum NCU0413, } \\
\text { Lactobacillus acidophilus NCU433, } \\
\text { Lactobacillus rhamnosus NCU2217 y } \\
\text { Lactobacillus paracasei NCU622 }\end{array}$ & $\begin{array}{l}\text { Ratones alimentados con } \\
\text { una dieta alta en grasa con } \\
\text { suplementos de } 1 \cdot 10^{8} \\
\text { UFC/mL durante } 9 \\
\text { semanas }\end{array}$ & $\begin{array}{l}\text { Reducción del peso corporal y } \\
\text { el índice de Lee, regulación de } \\
\text { los niveles del metabolismo de } \\
\text { los lípidos, del nivel de leptina } \\
\text { y adiponectina, de los } \\
\text { triglicéridos en el hígado y } \\
\text { mejora de la morfología de los } \\
\text { tejidos adiposos }\end{array}$ & [129] \\
\hline Lactobacillus sakei ADM14 & $\begin{array}{l}\text { Ratones alimentados con } \\
\text { dieta alta en grasa con } \\
\text { dosis de } 1 \cdot 10^{9} \mathrm{UFC} / \mathrm{mL}\end{array}$ & $\begin{array}{l}\text { Reducción del aumento de } \\
\text { peso, la expansión de grasa del } \\
\text { epidídimo, los niveles de } \\
\text { glucosa y colesterol en sangre } \\
\text { total, y la expresión de genes } \\
\text { relacionados con los lípidos en } \\
\text { la almohadilla de grasa del } \\
\text { epidídimo }\end{array}$ & [130] \\
\hline Lactobacillus sakei OK67 y PK16 & $\begin{array}{l}\text { Ratones alimentados con } \\
\text { dieta alta en grasa durante } \\
4 \text { semanas }\end{array}$ & $\begin{array}{l}\text { Reducción del peso corporal y } \\
\text { la expresión AMPK y SIRT-1 en } \\
\text { el hígado, activación de NF-KB } \\
\text { mediante la regulación de la } \\
\text { composición de la microbiota } \\
\text { intestinal }\end{array}$ & [131] \\
\hline Lactobacillus plantarum Ln4 & $\begin{array}{l}\text { Ratones alimentados con } \\
\text { un dieta alta en grasa } \\
\text { suplementados con } 5 \cdot 10^{8} \\
\text { UFC/mL durante } 5 \\
\text { semanas }\end{array}$ & $\begin{array}{l}\text { Disminución de la masa grasa, } \\
\text { resistencia a la insulina y los } \\
\text { biomarcadores relacionados } \\
\text { con la diabetes tipo } 2\end{array}$ & [132] \\
\hline
\end{tabular}


Introducción

\begin{tabular}{|c|c|c|c|}
\hline Lactobacillus reuteri 263 & $\begin{array}{l}\text { Ratas Sprague- Dawley } \\
\text { alimentadas con una dieta } \\
\text { alta en grasa con dosis de } \\
2,2 \cdot 10^{9} \text { y } 1,05 \cdot 10^{10} \text { UFC } / \mathrm{kg} \\
\text { día durante } 8 \text { semanas }\end{array}$ & $\begin{array}{l}\text { Prevención de la obesidad y los } \\
\text { niveles séricos de factores } \\
\text { proinflamatorios y enzimas } \\
\text { antioxidantes. Regulación al } \\
\text { alza de los niveles de ARNm de } \\
\text { genes relacionados con el } \\
\text { pardeamiento Ppary, Prdm16, } \\
\text { Bmp7 y Fgf21, la proteína } \\
\text { morfogenética ósea y el factor } \\
\text { de crecimiento de fibroblastos. } \\
\text { Alteración de los niveles de } \\
\text { ARNm de los genes del } \\
\text { metabolismo de la glucosa y } \\
\text { los lípidos, incluido el aumento } \\
\text { del transportador de } \\
\text { glucosaGlut4 y Chrebp y la } \\
\text { proteína de unión a elementos } \\
\text { que responde a los } \\
\text { carbohidratos }\end{array}$ & [133] \\
\hline $\begin{array}{l}\text { Leche de soja fermentada con } \\
\text { Bifidobacterium bifidum, } \\
\text { Lactobacillus casei y Lactobacillus } \\
\text { plantarum }\end{array}$ & $\begin{array}{l}\text { Ratones alimentados con } \\
\text { dieta alta en grasa y } \\
\text { suplementada con } 10^{8} \\
\text { UFC/ } \mathrm{mL} \text { en leche de soya } \\
\text { durante } 6 \text { semanas }\end{array}$ & $\begin{array}{l}\text { Reducción del aumento de } \\
\text { peso corporal, hiperlipidemia, } \\
\text { acumulación de grasa hepática } \\
\text { y niveles séricos de alanina } \\
\text { aminotransferasa y LPS, } \\
\text { producción de LPS hepático, } \\
\text { TNF- } \alpha \text { y el estrés oxidativo }\end{array}$ & [134] \\
\hline $\begin{array}{l}\text { Lactobacillus reuteri L3 } \\
\text { y Lactobacillus reuteri L10 }\end{array}$ & $\begin{array}{l}48 \text { ratones macho C57BL / } \\
6 \mathrm{~J} \text { alimentados con una } \\
\text { dieta alta en grasa y } \\
\text { consumo diario de } 10{ }^{10} \\
\text { UFC/mL }\end{array}$ & $\begin{array}{l}\text { El Lactobacillus reuteri redujo } \\
\text { el peso corporal, la glucosa, la } \\
\text { insulina, el lipopolisacárido } \\
\text { (LPS) y los niveles de citocinas } \\
\text { proinflamatorias y aumentó el } \\
\text { gasto de energía, los niveles de } \\
\text { RNAm de Ppar- } \gamma \text {, Acc1, y Fas en } \\
\text { los adipocitos, y el nivel de } \\
\text { ARNm de Cyp7a1 en el hígado }\end{array}$ & [135] \\
\hline Kéfir probiótico & $\begin{array}{l}\text { Ensayo doble ciego } \\
\text { controlado con placebo, } \\
\text { paralelo ciego aleatorizado } \\
\text { y controlado en el que se } \\
\text { asignó aleatoriamente } 48 \\
\text { sujetos con un volumen de } \\
\text { consumo por día de } 1,6 \\
\mathrm{~mL} / \mathrm{kg} \text { de peso corporal } \\
\text { para hombres y } 1,9 \mathrm{~mL} / \mathrm{kg} \\
\text { de peso corporal para } \\
\text { mujeres }\end{array}$ & $\begin{array}{l}\text { Disminuyó el riesgo de sufrir } \\
\text { enfermedades metabólicas y } \\
\text { cardiovasculares, los niveles } \\
\text { séricos de triglicéridos y los } \\
\text { niveles de colesterol LDL } \\
\text { oxidado y de lipoproteínas } \\
\text { aterogénicas (LDL, VLDL y sus } \\
\text { remanentes). Pero } \\
\text { aumentaron los niveles de } \\
\text { HDLc en mujeres }\end{array}$ & [136] \\
\hline $\begin{array}{l}\text { Pasta integral suplementada con } \beta \text { - } \\
\text { glucanos de cebada y Bacillus } \\
\text { coagulans BC30, }\end{array}$ & $\begin{array}{l}\text { Estudio de intervención } \\
\text { dietética simple ciego, } \\
\text { paralelo, aleatorizado y } \\
\text { controlado con } 46 \text { sujetos } \\
\text { entre hombres y mujeres } \\
\text { entre } 30 \text { a } 65 \text { años con IMC } \\
\text { entre } 25 \text { y } 35 \mathrm{~kg} / \mathrm{m}^{2} \\
\text { durante } 12 \text { semanas }\end{array}$ & $\begin{array}{l}\text { Disminución del cociente de } \\
\text { colesterol LDL/HDL plasmático } \\
\text { y proteína C reactiva (PCR) }\end{array}$ & [137] \\
\hline
\end{tabular}




\begin{tabular}{|c|c|c|c|}
\hline $\begin{array}{l}\text { Lactobacillus casei } 01 \text { y queso Minas } \\
\text { Frescal }\end{array}$ & $\begin{array}{l}\text { Ensayo aleatorizado doble } \\
\text { ciego con mujeres } \\
\text { hipertensas con sobrepeso } \\
\text { y consumo diario de } 10^{8} \\
\text { UFC/g por día durante } 4 \\
\text { semanas }\end{array}$ & $\begin{array}{l}\text { El probiótico mejora el } \\
\text { colesterol unido a } \\
\text { lipoproteínas de baja y alta } \\
\text { densidad y los triacilglicéridos }\end{array}$ & [138] \\
\hline Lactobacillus gasseri BNR17 & $\begin{array}{l}\text { Estudio aleatorio, doble } \\
\text { ciego controlado con } \\
\text { placebo en } 90 \text { voluntarios } \\
\text { de } 20 \text { a } 75 \text { años con IMC de } \\
25-35 \mathrm{~kg} / \mathrm{m}^{2} \text { recibieron } \\
\text { dosis bajas de } 10^{9} \text { UFC y } \\
\text { altas de } 10^{10} \text { UFC por día } \\
\text { durante } 12 \text { semanas }\end{array}$ & $\begin{array}{l}\text { Reducción WC y el tejido } \\
\text { adiposo visceral en dosis alta y } \\
\text { baja }\end{array}$ & {$[80]$} \\
\hline $\begin{array}{l}\text { Leche fermentada con } \\
\text { Bifidobacterium lactis HN019 }\end{array}$ & $\begin{array}{l}\text { Seleccionaron } 51 \text { pacientes } \\
\text { con síndrome metabólico } \\
\text { de pista controlado } \\
\text { aleatorizados, y consumo } \\
\text { diario de } 3,4 \cdot 10^{8} \mathrm{UFC} / \mathrm{mL} \\
\text { durante } 45 \text { días }\end{array}$ & $\begin{array}{l}\text { Reducción del peso corporal } \\
\text { máximo, el colesterol total y } \\
\text { los niveles de lipoproteínas de } \\
\text { baja densidad y disminución de } \\
\text { citocinas proinflamatorias de } \\
\text { TNF- } \alpha \text { e IL-6. }\end{array}$ & [139] \\
\hline $\begin{array}{l}\text { Yogur probiótico enriquecido con } \\
\text { Lactobacillus acidophilus La5, } \\
\text { Bifidobacterium BB12 y Lactobacillus } \\
\text { casei DN001 } 10\end{array}$ & $\begin{array}{l}\text { Ensayo controlado } \\
\text { aleatorio, doble ciego en } \\
75 \text { sujetos sanos con } \\
\text { sobrepeso y obesidad con } \\
\text { dosis de } 10^{8} \text { UFC } / \mathrm{mL} \\
\text { durante } 8 \text { semanas }\end{array}$ & $\begin{array}{l}\text { Reducción del índice máximo } \\
\text { corporal y del porcentaje de } \\
\text { grasa corporal, niveles séricos } \\
\text { de leptina y proteína C reactiva } \\
\text { de alta sensibilidad, y la } \\
\text { expresión de ARNm del } \\
\text { receptor gamma huérfano } \\
\text { relacionado con RAR en células } \\
\text { mononucleares de sangre } \\
\text { periférica }\end{array}$ & {$[140]$} \\
\hline $\begin{array}{l}\text { Lactobacillus rhamnosus CGMCC1 } \\
3724\end{array}$ & $\begin{array}{l}\text { Ensayo aleatorizado, doble } \\
\text { ciego, controlado con } \\
\text { placebo. Cada sujeto } \\
\text { consumió dos cápsulas por } \\
\text { día de } 10^{8} \mathrm{UFC} / \mathrm{mL} \text { con } 300 \\
\mathrm{mg} \text { de una mezcla de } \\
\text { oligofructosa y inulina }\end{array}$ & $\begin{array}{l}\text { Sin cambios significativos en el } \\
\text { peso corporal y la masa grasa } \\
\text { durante el período de } \\
\text { mantenimiento de peso en los } \\
\text { hombres. Pérdida de peso } \\
\text { significativa en mujeres } \\
\text { asociada con la reducción de la } \\
\text { masa grasa, las } \\
\text { concentraciones de leptina } \\
\text { circulante y la abundancia } \\
\text { relativa de bacterias de la } \\
\text { familia Lachnospiraceae en las } \\
\text { heces }\end{array}$ & [141] \\
\hline
\end{tabular}

\subsection{Estrategias político-sanitarias orientadas a la prevención $y / 0$ disminución de las enfermedades no transmisibles en Colombia.}

La prevención y/o disminución de la incidencia de las enfermedades no trasmisibles en Colombia es una prioridad. Este hecho empezó a establecerse en la Declaración del Milenio, aprobado en septiembre de 2000 
por 189 miembros de las Naciones Unidas. En esta declaración se acordó el cumplimiento de los Objetivos de Desarrollo del Milenio (ODM), por parte de números países, entre ellos Colombia, y contando con la vinculación de organizaciones internacionales. La evaluación del cumplimiento de los ODM dio paso a la adhesión en el establecimiento de los 17 Objetivos de Desarrollo Sostenible (ODS) en 2015. El estado colombiano llevó a cabo la implementación de la Agenda 2030 y la articulación de los Objetivos de Desarrollo Sostenible en su Plan Nacional de Desarrollo (PND) 2014-2018 "Todos por un nuevo país". Entre las acciones en las que Colombia participa hacía el cumplimiento de los ODS merece destacar:

La firma del Acuerdo de París el 12 de diciembre de 2015 en la 21으 Conferencia de las Partes de la Convención Marco de Naciones Unidas sobre Cambio Climático (COP21). Colombia se comprometió a reducir el 20\% de sus emisiones de gases invernadero para el 2030.

- La colaboración con La Organización para la Cooperación y el Desarrollo Económico (OCDE). La OCDE es una organización internacional cuya misión es diseñar mejores políticas para una vida mejor y promover políticas que favorezcan la prosperidad, la igualdad, las oportunidades y el bienestar para todas las personas.

- $\quad$ La elección, por parte de la FAO en 2019, de la Región Central de Colombia que reúne a Cundinamarca, Boyacá, Meta, Tolima y Bogotá para formar parte del Pacto Mundial por la Seguridad Alimentaria o Pacto de Milán. Así, se convierte en la primera región de América Latina en ser parte de este marco de acción que busca promover la alimentación saludable de forma sostenible.

En 2009, se crea la Ley 1355 que declara el sobrepeso y la obesidad como enfermedades crónicas. En dicha ley, la obesidad se reconoce como uno de los problemas de salud pública que requieren de acciones para su control y prevención.

En marzo de 2013, la Comisión intersectorial de Seguridad Alimentaria y Nutricional (CISAN) establece el Plan Nacional de Seguridad Alimentaria y Nutricional 2012-2019, en cumplimiento en lo establecido en el Consejo Nacional de Política Económica Social (CONPES 133 de 2008), por el cual se adopta la Política Nacional de Seguridad Alimentaria y Nutricional. El objetivo de dicho plan es contribuir a la mejora de la situación alimentaria y nutricional de toda la población y en especial de la más pobre y vulnerable. 
También para dar respuestas y asumir responsabilidades a nivel nacional y regional en relación a la actividad física, alimentación saludable y ambiente sano se estableció, en 2019, el Documento CONPES Social: "POLÍTICA PÚBLICA DE SEGURIDAD ALIMENTARIA Y NUTRICIONAL PARA BOGOTÁ: Construyendo Ciudadanía Alimentaria 2019-2031" (Secretaría Distrital de Desarrollo Económico, 2019) en el que se contemplan metas y estrategias orientadas a dar respuesta a la problemática de salud pública relacionada con el sobrepeso y la obesidad. En el plan se establecen cinco ejes fundamentales: disponibilidad suficiente, aprovechamiento biológico, y calidad e inocuidad de los alimentos; actividad física y estilo de vida saludable; acceso físico y económico y sus principios de derecho a la equidad social; perspectiva de género, respeto a la identidad y diversidad cultural; y sostenibilidad [142].

Una de las acciones que se llevan a cabo y que se realizan en alianza con las diferentes instituciones a nivel nacional y local, es promover la actividad física de al menos 15 minutos en la población adulta y de al menos 60 minutos en los jóvenes y los niños [142]. La Comisión de Seguridad Alimentaria y Nutricional (CISAN) además de hacer alianzas con las diferentes instituciones, también tiene como objetivo hacer seguimiento interinstitucional, de articulación de políticas y programas de seguimientos de la Seguridad Alimentaria y Nutricional entregada por el Ministerio de Agricultura y Desarrollo Rural, Ministerio de Protección Social, Ministerio de Comercio e Industria, Ministerio de Educación Nacional y Ministerio de Ambiente, Vivienda y Desarrollo Territorial y Instituto de Bienestar Familiar.

En el departamento del Chocó las enfermedades no trasmisibles también representan un problema salud pública; según el Plan de Desarrollo del municipio de Quibdó, los índices de sobrepeso y obesidad han aumentado en los últimos años. Cabe mencionar que, en el departamento del Chocó, las instituciones de la salud no cuentan con un sistema que incorpore unas políticas claras para la prevención y tratamiento de enfermedades no trasmisibles. Por ello, desde esta investigación se busca generar recomendaciones orientadas a resaltar la importancia del diseño e implementación de estrategias para dar respuesta a estos problemas. 


\subsection{Despilfarro alimentario, procesado sostenible y alimentos nutritivos}

El constante aumento de la población humana exige una mayor cantidad de alimentos. Por otra parte, la industria alimentaria y de forma específica el sector hortofrutícola, generan una gran cantidad de subproductos y residuos cuyo aprovechamiento representa un desafío global. Este aprovechamiento, en lo que se conoce como la economía circular, está inequívocamente vinculado a la seguridad alimentaria y a la gestión de recursos y tiene importantes implicaciones ambientales, sociales y económicas. Reducir los residuos permite reducir los costos de producción, aumentar la eficiencia del sistema alimentario, mejorar la seguridad alimentaria y la nutrición y contribuir a un sistema más sostenible desde el punto de vista ambiental $[143,144]$.

La Organización de las Naciones Unidas para la Agricultura y la Alimentación [145], estima que, cada año, aproximadamente, un tercio de todos los alimentos producidos para el consumo humano en el mundo se desperdician. A nivel mundial, se estima que el volumen de desperdicio de alimentos comestibles es de millones de toneladas al año. Según el ranking de despilfarro alimentario, las regiones con mayor contribución se encuentran en Asia central y meridional con un $20 \%$, América del Norte con un $21 \%$, Europa con el $16 \%$ y América Latina y el Caribe con un $20 \%$. En relación con los grupos alimenticios; el nivel más alto de pérdidas va desde la postcosecha hasta la distribución. Dentro de la postcosecha, los tubérculos de raíz y los cultivos oleaginosos representan el $25 \%$, seguidos por las frutas y hortalizas que representan el $22 \%$. Se estima que los costes productivos representan alrededor de 1 billón de dólares, los costes ambientales alrededor de 700 mil millones de dólares y los costes sociales alrededor de 900 mil millones de dólares al año [146,147].

Los datos anteriores resultan paradójicos si tenemos en cuenta que, aproximadamente más de 690 millones de personas padecen hambre en el mundo. El Objetivo de Desarrollo Sostenible (ODS) 12: Producción y consumo sostenible, incluye para 2030, reducir a la mitad el desperdicio de alimentos global per cápita, a nivel minorista y de consumo, y reducir las pérdidas de alimentos a lo largo de la cadena de producción y suministro, incluidas las pérdidas posteriores a la cosecha [148]. 
La reducción en las pérdidas de alimentos y en la generación de subproductos y residuos contribuirá de forma importante a la sostenibilidad ambiental. Con base en los datos del estudio de la Organización de las Naciones Unidas para la Agricultura y la Alimentación, se estima que la huella de carbono global es de 3,3 gigatoneladas de dióxido de carbono atribuible al despilfarro de alimentos, lo que contribuye a alrededor del $7 \%$ del total de gases de efecto invernadero [149].

Las industrias alimentarias generan anualmente alrededor de 1,300 millones de toneladas de desechos. Aproximadamente el 38\% corresponde a subproductos de operaciones de procesado de frutas y hortalizas [150]. Sin embargo, diferentes estudios demuestran que muchos de estos residuos son ricos en componentes bioactivos, incluida la fibra dietética, los compuestos fenólicos, los aminoácidos y los fitoquímicos como minerales, vitaminas y carotenoides. Por esta razón, estos residuos tienen un gran potencial para ser utilizados como ingredientes funcionales o para la extracción de compuestos bioactivos que puedan utilizarse por la industria alimentaria como aditivos naturales o por la industria farmacéutica para la fabricación de nutracéuticos $[160,161,162]$.

Las técnicas de extracción más utilizadas son la extracción sólidolíquido y la extracción líquido- líquido. Sin embargo, a menudo, estos métodos requieren la utilización de grandes volúmenes de disolventes, con la consiguiente generación de efluentes contaminantes, y también la aplicación de temperaturas moderadas o altas que pueden provocar la degradación de los compuestos termolábiles. Con la finalidad de reducir estos inconvenientes, se está realizando una gran actividad de investigación en la aplicación de técnicas novedosas como la extracción asistida por ultrasonidos, por pulsos eléctricos, por enzimas, por microondas, por altas presiones hidrostáticas o la extracción asistida con fluidos supercríticos. Se trata de técnicas mucho más sostenibles y eficaces debido a la menor cantidad de disolventes residuales generados $[153,154]$. Los polifenoles y los carotenoides son los grupos de compuestos bioactivos con mayor interés en los procesos de extracción. La tabla 1.4 muestra algunos ejemplos de trabajos de investigación centrados en la extracción de polifenoles o carotenoides de subproductos vegetales. 
Tabla 1.4. Compuestos bioactivos y métodos de extracción aplicados en subproductos de frutas.

\begin{tabular}{|c|c|c|c|}
\hline Muestra & Compuestos bioactivos & Método de extracción & Referencias \\
\hline Piel de mango & Compuestos fenólicos & $\begin{array}{l}\text { Extracción asistida por } \\
\text { microondas }\end{array}$ & [155] \\
\hline Piel de uva & $\begin{array}{lll}\text { Compuestos } & \text { fenólicos } & y \\
\text { antocianinas } & & \end{array}$ & $\begin{array}{l}\text { Extracción asistida por } \\
\text { enzimas y alta presión } \\
\text { hidrostática }\end{array}$ & [156] \\
\hline $\begin{array}{l}\text { Residuos de } \\
\text { acerola, guayaba y } \\
\text { genipap }\end{array}$ & \begin{tabular}{llr} 
Compuesto & \multicolumn{2}{r}{ fenólicos } \\
(Naringenina & y rutina) y \\
carotenoides & (licopeno, $\beta-$ \\
caroteno & y & trans- \\
cantaxantina) & &
\end{tabular} & $\begin{array}{ll}\text { Extracción } & \text { asistida } \\
\text { ultrasónica } & \end{array}$ & [157] \\
\hline Piel de aguacate & $\begin{array}{l}\text { Procianidinas, catequinas y } \\
\text { ácidos fenólicos }\end{array}$ & $\begin{array}{l}\text { Extracción asistida por } \\
\text { microondas }\end{array}$ & [158] \\
\hline Piel de araçá roja & $\begin{array}{l}\text { Antocianinas } \quad \text { (cianidin-3- } \\
\text { glucósido), carotenoides ( } \beta- \\
\text { caroteno) }\end{array}$ & $\begin{array}{l}\text { Extracción asistida por } \\
\text { ultrasonido }\end{array}$ & [159] \\
\hline Piel de aguacate & $\begin{array}{l}\text { Compuestos fenólicos } \\
\text { (procianidinas y catequinas) }\end{array}$ & $\begin{array}{l}\text { Extracción asistida por } \\
\text { microondas y extracción } \\
\text { convencional sólido- } \\
\text { líquido }\end{array}$ & [160] \\
\hline Piel de granada & $\begin{array}{l}\text { Contenido fenólico total } \\
\text { (punicalagina) }\end{array}$ & $\begin{array}{l}\text { Extracción líquida } \\
\text { presurizada }\end{array}$ & [161] \\
\hline Semillas de uva & $\begin{array}{ll}\begin{array}{l}\text { Polifennoles } \\
\text { fenólico total) }\end{array} & \text { (contenido } \\
\end{array}$ & $\begin{array}{l}\text { Extracción asistida con } \\
\text { enzimas y microondas }\end{array}$ & {$[162]$} \\
\hline $\begin{array}{l}\text { Subproductos de } \\
\text { maracuyá }\end{array}$ & 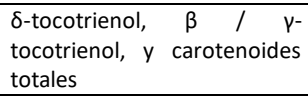 & $\begin{array}{l}\text { Extracción con fluidos } \\
\text { supercríticos }\end{array}$ & {$[163]$} \\
\hline Piel de granada & $\begin{array}{ll}\text { Compuestos } & \text { pollfenólicos } \\
\text { (punicalagina) } & \end{array}$ & $\begin{array}{l}\text { Extracción } \\
\text { ultrasonido }\end{array}$ & {$[164]$} \\
\hline Piel de kiwi & $\begin{array}{ll}\text { Polifenoles } & \text { (contenido } \\
\text { fenólico total) } & \end{array}$ & $\begin{array}{l}\text { Extracción con agua } \\
\text { subcrítica }\end{array}$ & {$[165]$} \\
\hline Piel de zanahoria & $\begin{array}{l}\text { Carotenoides } \quad \text { (luteína, } \\
\text { licopeno, } \alpha \text { - caroteno, } \beta- \\
\text { caroteno) }\end{array}$ & Extracción supercrítica & [166] \\
\hline Cáscara de pistacho & $\begin{array}{l}\text { Componentes polifenólicos } \\
\text { (ácidos anacárdicos, ácido } \\
\text { protocatéquico, quercetina } \\
\text { 3- O galactósido, cianidina 3- } \\
\text { O- } \beta \text { - d -galactopiranósido) }\end{array}$ & $\begin{array}{l}\text { Extracción asistida por } \\
\text { ultrasonidos }\end{array}$ & {$[167]$} \\
\hline Piel de papa & $\begin{array}{l}\text { Contenido fenólico, actividad } \\
\text { antioxidante y compuestos } \\
\text { polifenoles: ácido } \\
\text { clorogénico y ácido cafeico }\end{array}$ & $\begin{array}{l}\text { Extracción sólido- líquido } \\
\text { y extracción asistida por } \\
\text { ultrasonido }\end{array}$ & [168] \\
\hline Piel de naranja & $\begin{array}{l}\text { Flavonoides (hesperidina, } \\
\text { neohesperdina, erocitrina, } \\
\text { narirutin,naringin, dimymin, } \\
\text { sinensetin, } \\
\text { hexametoxiflavona, } \\
\text { tangeretina y nobiletin) }\end{array}$ & $\begin{array}{l}\text { Extracción asistida con } \\
\text { microondas, } \\
\text { ultrasonidos, supercrítica } \\
\text { y extracción a alta } \\
\text { presión }\end{array}$ & [169] \\
\hline
\end{tabular}


La creciente demanda de ingredientes bioactivos como los polifenoles, junto con la abundancia de subproductos alimentarios hacen que su investigación sea un campo atractivo. En particular, en los últimos años, se han publicado trabajos de investigación relacionados con la extracción de más de 1000 compuestos polifenólicos a partir de residuos de plantas, frutas y hortalizas para su incorporación en alimentos. Los alimentos más comunes a los que se pueden incorporar estos compuestos bioactivos incluyen los productos derivados de cereales como pan, galletas, tortas y muffins en los que contribuyen a mejorar el perfil nutricional del alimento; y los productos lácteos con el fin de reducir la oxidación de lípidos mejorando su vida útil o el efecto probiótico en los lácteos fermentados [170].

Otras aplicaciones interesantes derivan de la capacidad antimicrobiana de algunos de estos compuestos, actuando como conservantes naturales y sin interferir en la viabilidad de los cultivos iniciadores y otros microorganismos involucrados en los procesos de fermentación; su papel como hidrocoloides naturales y como espesantes de bebidas lácteas $u$ otras sustitutivas de la leche. En otros casos, los subproductos ricos en fibra pueden ser utilizados en su totalidad y tras un proceso de estabilización como la deshidratación, ser utilizados para mejorar las propiedades de sopas, emulsiones o incluso productos cárnicos, gracias a su capacidad de retención de agua, capacidad de retención de aceite, su capacidad de hinchamiento, y/o de formar geles [171,172].

\subsection{Tecnologías aplicadas en la fabricación de alimentos funcionales}

En esta tesis doctoral se han aplicado las técnicas de impregnación a vacío, secado por aire caliente, homogeneización por altas presiones y fermentación, para el desarrollo de alimentos funcionales dirigidos a la población infantil con desnutrición y/o a la población adulta con obesidad e hipertensión del Departamento del Chocó (Colombia), a partir del fruto del lulo. A continuación, se describen, en términos generales, estas técnicas.

\subsubsection{La impregnación a vacío de alimentos}

La técnica de impregnación a vacío (IV) es una operación de transferencia de masa que ocurre cuando las estructuras porosas se sumergen 
en una fase líquida y se aplica una presión subatmosférica. Los gradientes de presión originan flujos de gas y líquido entre la estructura porosa y el medio líquido en el que se encuentra sumergida. En alimentos con propiedades viscoelásticas como lo son la mayoría de las frutas y hortalizas, este intercambio de materia ocurre acoplado con fenómenos de deformación de la estructura sólida del alimento. El acoplamiento entre los dos fenómenos, y por tanto, la cantidad de líquido intercambiado se ve afectada por la microestructura del alimento: La distribución del tamaño de los poros, la morfología y la porosidad del producto sólido [173]. Ambos fenómenos provocan importantes cambios en las propiedades físicas del producto.

La IV puede utilizarse para incorporar componentes de diferente naturaleza disueltos o suspendidos en un medio líquido a alimentos porosos como frutas y hortalizas, sin modificar la estructura original del alimento. Además, resulta muy eficaz para prevenir el pardeamiento enzimático en frutas, debido a la eliminación de oxígeno de los poros. Algunas aplicaciones interesantes son: La incorporación de conservantes, crioprotectores, enzimas, compuestos bioactivos o nutritivos como vitaminas, minerales y microorganismos probióticos $[174,175]$. Por ejemplo, la sacarosa impregnada en los poros de las peras cortadas protegió la estructura del tejido natural, mejorando las propiedades texturales en las operaciones posteriores de secado, enlatado o congelación [176,177]. El zumo de mandarina inoculado con Lactobacillus salivarius ssp impregnado en rodajas de manzanas sufrió menos efectos negativos después de las operaciones de secado con aire caliente [178]. De igual manera, el zumo de arándano incorporado en rodajas de manzana fresca mediante la impregnación a vacío conservó mejor los compuestos bioactivos [179]. Por último, señalar que tras la aplicación de la IV los alimentos tienen una humedad elevada y una baja vida útil y deben ser estabilizados para su conservación.

\subsubsection{La deshidratación}

Las operaciones de deshidratación se aplican a los alimentos con el objetivo principal de reducir la humedad del producto a un nivel seguro para el almacenamiento y transporte a temperatura ambiente, evitar la multiplicación microbiana y la actividad enzimática y, en consecuencia, prolongar la vida útil de los productos alimenticios. Los productos secos son más aptos para su manipulación, ya que su reducido volumen ayuda a reducir los costes de empaquetado, transporte y almacenamiento. Se trata de una 
operación muy extendida y que puede llevarse a cabo de forma sencilla sin grandes costes de inversión cuando se deshidrata por aire caliente. Otros métodos como la liofilización, aunque requieren mayores costes de inversión y funcionamiento, evitan las reacciones de oxidación y de degradación de componentes termolábiles asociadas al secado por aire caliente. La liofilización permite conservar el valor nutritivo y funcional de las frutas, y permite obtener alimentos deshidratados de alta calidad con cambios mínimos en el sabor, color, apariencia y composición nutricional de la materia prima inicial. Por el contrario, el alimento ve modificadas en gran medida sus características estructurales y resulta imposible someterlo a una rehidratación posterior [180].

\subsubsection{Las altas presiones de homogenización (HPH)}

En la técnica de $\mathrm{HPH}$, se fuerza a un alimento líquido a que pase a través de un hueco u orificio estrecho, causando tensiones mecánicas (cizallamientos) y aumentando levemente la temperatura a medida que se aplica mayor presión (entre 14 y $16^{\circ} \mathrm{C}$ por cada $100 \mathrm{MPa}$ ). Como consecuencia, la estructura y las propiedades del fluido se modifican: Disminuye el tamaño de partícula y se alcanza una mayor estabilidad de las partículas suspendidas, facilitando así operaciones como la mezcla y la emulsión [181]. El efecto del tratamiento de $\mathrm{HPH}$ depende de la presión aplicada, del número de pasadas repetidas y de la geometría de la válvula.

Se trata de una tecnología no térmica que en los últimos años ha despertado interés para disminuir los tratamientos térmicos de conservación de bebidas: Permite la destrucción de microorganismos y la inactivación de enzimas. Además, puede aplicarse en zumos de frutas reduciendo la intensidad del tratamiento térmico de conservación y aumentando la calidad de estos. Al ser forzados a pasar a través del pequeño orificio, se altera la microestructura del zumo, disminuyendo el tamaño de las partículas suspendidas y aumentando la estabilidad de la nube. Al mantener la pulpa en suspensión, el zumo resultante conserva una mayor parte de la fibra y de los componentes bioactivos de la fruta fresca, resultando en un producto más saludable [182]. Al mismo tiempo se favorece la liberación al medio líquido de compuestos fenólicos ubicados en el interior de las vacuolas de las partículas sólidas, y de los carotenoides que generalmente se encuentran en la membrana del cloroplasto o en los cromoplastos, mejorando la bioaccesibilidad de los mismos $[183,184]$. En relación con algunas cepas de 
microorganismos con efecto probiótico, se ha comprobado en algunos trabajos, que el tratamiento de HPH mejora la supervivencia de las cepas y su resistencia al proceso de digestión gastrointestinal in vitro [178]. Con respecto a los compuestos bioactivos, el tratamiento de HPH aumentó el contenido de flavoniodes tales como: hesperidina, narirutina y la didimina en zumo de mandarina [185].

\subsubsection{La fermentación}

La fermentación se aplica desde tiempos antiguos como una estrategia eficaz para conservar los alimentos. Hoy en día, a menudo, la fermentación se lleva a cabo con microorganismos probióticos que además de garantizar la consistencia y calidad de los productos fermentados, confieren a estos efectos beneficiosos sobre la salud [186]. Su importancia radica en el amplio espectro de alimentos fermentados que se comercializan tanto en países en desarrollo como en los industrializados. Entre los beneficios que los alimentos fermentados confieren a los seres humanos cabe destacar: Un aumento en la digestibilidad, la eliminación de factores antinutritivos, la inhibición del crecimiento de bacterias patógenas y otros beneficios en la prevención de enfermedades como las enfermedades cardiovasculares [187]. Recientemente, ha habido un creciente interés científico hacia el desarrollo de bebidas funcionales a base de zumo de frutas con ingredientes probióticos. Incluso se ha afirmado que son vehículo ideal para los ingredientes funcionales. Las bacterias ácido- lácticas se han considerado tradicionalmente como microorganismos exigentes que requieren aminoácidos y vitaminas esenciales para su crecimiento; existen varias cepas como Lactocillus plantarum, Lactocacillus acidophilus y Lactobacillus casei y la Lactobacills reuteri que pueden crecer en matrices de frutas debido a su notable tolerancia a ambientes ácidos [188]. 


\section{Bibliografía}

1. Rodrigues, T.C.; Leitão, F.O.; Thomé, K.M.; Cappellesso, G. Sharing economy practices in agri-food settlements: Integration of resources, interdependence and interdefinition. J. Clean. Prod. 2021, 294, 126357.

2. Rother, H.A. Controlling and preventing climate-sensitive noncommunicable diseases in urban sub-Saharan Africa. Sci. Total Environ. 2020, 722, 137772.

3. Spiker, M.; Reinhardt, S.; Bruening, M. Academy of Nutrition and Dietetics: Revised 2020 Standards of Professional Performance for Registered Dietitian Nutritionists (Competent, Proficient, and Expert) in Sustainable, Resilient, and Healthy Food and Water Systems. J. Acad. Nutr. Diet. 2020, 120, 1568-1585.e28

4. Alaimo, K.; Chilton, M.; Jones, S.J. Food insecurity, hunger, and malnutrition; International Life Sciences Institute (ILSI). Published by Elsevier Inc., 2020; Vol. 2; ISBN 9780128184608.

5. FAO, FIDA, OPS, W. yU. Panorama de la seguridad alimentaria y nutricional en América Latina $y$ el Caribe 2020. Santiago,Chile Available online: http://www.fao.org/documents/card/es/c/cb2242es/ (accessed on Aug 27,2021)

6. Stella, G.; Coli, R.; Maurizi, A.; Famiani, F.; Castellini, C.; Pauselli, M.; Tosti, G.; Menconi, M.E. Towards a National Food Sovereignty Plan: Application of a new Decision Support System for food planning and governance. Land use policy 2019, 89, 104216.

7. FAO, Dietary guidelines and sustainability. Food-based dietary guidelines. Food and Agriculture Organization of the United Nations Available online: http://www.fao.org/nutrition/education/food-dietary-

guidelines/background/sustainable-dietary-guidelines/en/ (accessed on Aug 27, 2021).

8. Mayton, H.; Beal, T.; Rubin, J.; Sanchez, A.; Heller, M.; Hoey, L.; de Haan, S.; Duong, T.T.; Huynh, T.; Burra, D.D.; et al. Conceptualizing sustainable diets in Vietnam: Minimum metrics and potential leverage points. Food Policy 2020, 91, 101836.

9. Auestad, N.; Fulgoni, V.L. What current literature tells us about sustainable diets: Emerging research linking dietary patterns, environmental sustainability, and economics. Adv. Nutr. 2015, 6, 19-36.

10. Bignet, V.; Willett, W.; Cornell, S.; Rockström, J. Delineating the Plate Boundaries: A Review of Integrated Metrics for Healthy and Environmentally Sustainable Diets. Encycl. World's Biomes 2020, 5, 339-350.

11. Reipurth, M.F.S.; Hørby, L.; Gregersen, C.G.; Bonke, A.; Perez Cueto, F.J.A. Barriers and facilitators towards adopting a more plant-based diet in a sample of Danish consumers. Food Qual. Prefer. 2019, 73, 288-292.

12. Lizcano, S.C.; Dávila, J.A.; Hernández, V. Fruit Agroindustrial Wastes for Preparing Beverages for Medicinal Purposes by Supercritical Fluid Extraction Technology: Andes Berry (Rubus glaucus benth) Case. In Production and Management of Beverages; Elsevier, 2019; pp. 151-177.

13. Rodríguez-de-Francisco, J.C.; del Cairo, C.; Ortiz-Gallego, D.; Velez-Triana, J.S.; VergaraGutiérrez, T.; Hein, J. Post-conflict transition and REDD+ in Colombia: Challenges to reducing deforestation in the Amazon. For. Policy Econ. 2021, 127, 102450.

14. Vecino-Ortiz, A.I.; Arroyo-Ariza, D. A tax on sugar sweetened beverages in Colombia: Estimating the impact on overweight and obesity prevalence across socio economic levels. Soc. Sci. Med. 2018, 209, 111-116.

15. Plan de Desarrollo Departamental del Chocó. 2020-2023 -Gobernación del Chocó. Avaleible online: https://www.choco.gov.co/planes/plan-de-desarrollodepartamental-2020-2023 generando. (accessed on Jul, 2021).

16. Rangel-Ch, F.O. La biodiversidad de Colombia: significado y distribución regional. Rev. 
la Acad. Colomb. Ciencias Exactas, Física y Nat. 2015, 39, 176-200.

17. Ministerio de Salud y Protección Social. Análisis de Situación de Salud, Bogotá D.CColombia, 2019.

18. Ramírez, F.; Kallarackal, J.; Davenport, T.L. Lulo (Solanum quitoense Lam.) reproductive physiology: A review. Sci. Hortic. (Amsterdam). 2018, 238, 163-176.

19. Ministerio de Agricultura y Desarrollo Rural de Colombia Agronet Producción Nacional por Producto - Lulo Available online: https://www.agronet.gov.co/Paginas/ProduccionNacionalProducto.aspx (accessed on Feb 24, 2020).

20. Vargas, A.; F.J.; Sierra, R.S. Inteligencia de mercados para la cadena de lulo (solanum quitoense). J. Agric. Anim. Sci. 2015, 3, 38-47.

21. Gancel, A.L.; Alter, P.; Dhuique-Mayer, C.; Ruales, J.; Vaillant, F. Identifying carotenoids and phenolic compounds in naranjilla (Solanum quitoense Lam. var. Puyo hybrid), an Andean fruit. J. Agric. Food Chem. 2008, 56, 11892-11899.

22. Forero, D.P.; Orrego, C.E.; Peterson, D.G.; Osorio, C. Chemical and sensory comparison of fresh and dried lulo (Solanum quitoense Lam.) fruit aroma. Food Chem. 2015, 169, 85-91.

23. Acosta, Ó.; Pérez, A.M.; Vaillant, F. Chemical characterization, antioxidant properties, and volatile constituents of Naranjilla (Solanum quitoense Lam.) cultivated in Costa rica. Arch. Latinoam. Nutr. 2009, 59, 88-94.

24. Forero, D.P.; Masatani, C.; Fujimoto, Y.; Coy-Barrera, E.; Peterson, D.G.; Osorio, C. Spermidine derivatives in Iulo (Solanum quitoense Lam.) fruit: Sensory (taste) versus biofunctional (ACE-inhibition) properties. J. Agric. Food Chem. 2016, 64, 5375-5383.

25. Da Silva, L.M.R.; De Figueiredo, E.A.T.; Ricardo, N.M.P.S.; Vieira, I.G.P.; De Figueiredo, R.W.; Brasil, I.M.; Gomes, C.L. Quantification of bioactive compounds in pulps and byproducts of tropical fruits from Brazil. Food Chem. 2014, 143, 398-404.

26. Granato, D.; Santos, J.S.; Maciel, L.G.; Nunes, D.S. Chemical perspective and criticism on selected analytical methods used to estimate the total content of phenolic compounds in food matrices. TrAC Trends Anal. Chem. 2016, 80, 266-279.

27. Donado-Pestana, C.M.; dos Santos-Donado, P.R.; Daza, L.D.; Belchior, T.; Festuccia, W.T.; Genovese, M.I. Cagaita fruit (Eugenia dysenterica DC.) and obesity: Role of polyphenols on already established obesity. Food Res. Int. 2018, 103, 40-47.

28. Sentandreu, E.; Stinco, C.M.; Vicario, I.M.; Mapelli-Brahm, P.; Navarro, J.L.; MeléndezMartínez, A.J. High-pressure homogenization as compared to pasteurization as a sustainable approach to obtain mandarin juices with improved bioaccessibility of carotenoids and flavonoids. J. Clean. Prod. 2020, 262, 121325.

29. Ameye, H.; Swinnen, J. Obesity, income and gender: The changing global relationship. Glob. Food Sec. 2019, 23, 267-281.

30. World Health Organization Obesity Available online: https://www.who.int/healthtopics/obesity\#tab=tab_1 (accessed on Aug 27, 2021).

31. Jones, S.E. The Global Problem of Obesity. In Practical Guide to Obesity Medicine; Elsevier, 2018; pp. 1-7.

32. Litwin, S.E. Childhood obesity and adulthood cardiovascular disease. J. Am. Coll. Cardiol. 2014, 64, 1588-1590.

33. Seravalle, G.; Grassi, G. Obesity and hypertension. Pharmacol. Res. 2017, 122, 1-7.

34. Koh, K.; Grady, S.C.; Darden, J.T.; Vojnovic, I. Adult obesity prevalence at the county level in the United States, 2000-2010: Downscaling public health survey data using a spatial microsimulation approach. Spat. Spatiotemporal. Epidemiol. 2018, 26, 153-164.

35. Encuesta Nacional de Situación Nutricional. Ministerio de Protección Social, 2015, Available online: https://www.icbf.gov.co/bienestar/nutricion/encuesta-nacionalsituacion-nutricional (accessed on Aug 27, 2021).

36. Bull, F.C.; Al-Ansari, S.S.; Biddle, S.; Borodulin, K.; Buman, M.P.; Cardon, G.; Carty, C.; Chaput, J.P.; Chastin, S.; Chou, R.; et al. World Health Organization 2020 guidelines on 
physical activity and sedentary behaviour. Br. J. Sports Med. 2020, 54, 1451-1462.

37. Hawkes, C.; Ruel, M.T.; Salm, L.; Sinclair, B.; Branca, F. Double-duty actions: seizing programme and policy opportunities to address malnutrition in all its forms. Lancet 2020, 395, 142-155.

38. Kamonpatana, K. The Role of Food Industry in Improving Health. Encycl. Food Secur. Sustain. 2019, 267-274.

39. Ghaffari, S.; Roshanravan, N. The role of nutraceuticals in prevention and treatment of hypertension: An updated review of the literature. Food Res. Int. 2020, 128, 108749.

40. Unger, T.; Borghi, C.; Charchar, F.; Khan, N.A.; Poulter, N.R.; Prabhakaran, D.; Ramirez, A.; Schlaich, M.; Stergiou, G.S.; Tomaszewski, M.; et al. 2020 International Society of Hypertension Global Hypertension Practice Guidelines. Hypertension 2020, 75, 13341357.

41. Wyss, F.; Coca, A.; Lopez-Jaramillo, P.; Ponte-Negretti, C.; Wyss, F.S.; Restrepo, G.; Ponte-Negretti, C.I.; Lanas, F.; Pérez, G.; Sebba Barroso, W.; et al. Position statement of the Interamerican Society of Cardiology (IASC) on the current guidelines for the prevention, diagnosis and treatment of arterial hypertension 2017-2020. Int. J. Cardiol. Hypertens. 2020, 6, 100041.

42. Brouwers, S.; Sudano, I.; Kokubo, Y.; Sulaica, E.M. Seminar Arterial hypertension. Lancet 2021, 6736, 1-13.

43. Psara, E.; Pentieva, K.; Ward, M.; McNulty, H. Critical review of nutrition, blood pressure and risk of hypertension through the lifecycle: do $B$ vitamins play a role? Biochimie 2020, 173, 76-90.

44. Carey, R.M.; Muntner, P.; Bosworth, H.B.; Whelton, P.K. Prevention and Control of Hypertension: JACC Health Promotion Series. J. Am. Coll. Cardiol. 2018, 72, 1278-1293.

45. Richter, C.; Skulas-Ray, A.; Kris-Etherton, P. The role of diet in the prevention and treatment of cardiovascular disease. In Nutrition in the Prevention and Treatment of Disease; Elsevier, 2017; pp. 595-623 ISBN 9780128029282.

46. Moya, L.; Moreno, J.; Lombo, M.; Guerrero, C.; Aristizábal, D.; Vera, A.; Melgarejo, E.; Conta, J.; Gómez, C.; Valenzuela, D.; et al. Expert consensus on the clinical management of arterial hypertension in Colombia Colombian Society of Cardiology and Cardiovascular Surgery. Rev. Colomb. Cardiol. 2018, 25, 4-26.

47. Flórez-García, V.; Rojas-Bernal, L.Á.; Bareño-Silva, J. Depression and sleep disorders related to hypertension: A cross-sectional study in Medellín, Colombia. Rev. Colomb. Psiquiatr. (English ed.) 2020, 49, 108-114.

48. Nguyen Dinh Cat, A.; Montezano, A.C.; Burger, D.; Touyz, R.M. Angiotensin II, NADPH oxidase, and redox signaling in the vasculature. Antioxidants Redox Signal. 2013, 19, 1110-1120.

49. Varadharaj, S.; Kelly, O.J.; Khayat, R.N.; Kumar, P.S.; Ahmed, N.; Zweier, J.L. Role of Dietary Antioxidants in the Preservation of Vascular Function and the Modulation of Health and Disease. Front. Cardiovasc. Med. 2017, 4, 1.

50. Ferreira-Santos, P.; Aparicio, R.; Carrón, R.; Sevilla, M.Á.; Monroy-Ruiz, J.; Montero, M.J. Lycopene-supplemented diet ameliorates cardiovascular remodeling and oxidative stress in rats with hypertension induced by Angiotensin II. J. Funct. Foods 2018, 47, 279-287.

51. Feyh, A.; Bracero, L. Role of Dietary Components in Modulating Hypertension. J. Clin. Exp. Cardiolog. 2016, 07.

52. World Health Organization Fact sheets - Malnutrition Available online: https://www.who.int/news-room/fact-sheets/detail/malnutrition (accessed on Aug 12, 2021).

53. Scrinis, G. Reframing malnutrition in all its forms: A critique of the tripartite classification of malnutrition. Glob. Food Sec. 2020, 26, 100396.

54. FAO, Prevalence of undernourishment. Sustainable Development Goals. Food and Agriculture Organization 2021. Available online: http://www.fao.org/sustainable- 
development-goals/indicators/211/en/ (accessed on Aug 28, 2021).

55. Swaminathan, S.; Hemalatha, R.; Pandey, A.; Kassebaum, N.J.; Laxmaiah, A.; Longvah, T.; Lodha, R.; Ramji, S.; Kumar, G.A.; Afshin, A.; et al. The burden of child and maternal malnutrition and trends in its indicators in the states of India: the Global Burden of Disease Study 1990-2017. Lancet Child Adolesc. Heal. 2019, 3, 855-870.

56. Botero-Meneses, J.S.; Aguilera-Otalvaro, P.A.; Pradilla, I.; Talero-Gutiérrez, C.; RuizSternberg, Á.M.; Vélez-van-Meerbeke, A.; Pinzón-Rondón, A.M. Assessment of nutrition and learning skills in children aged 5-11 years old from two elementary schools in Chocó, Colombia. Heliyon 2020, 6, e03821.

57. Herrera Cuenca, M.; Proaño, G. V.; Blankenship, J.; Cano-Gutierrez, C.; Chew, S.T.H.; Fracassi, P.; Keller, H.; Venkatesh Mannar, M.G.; Mastrilli, V.; Milewska, M.; et al. Building Global Nutrition Policies in Health Care: Insights for Tackling Malnutrition from the Academy of Nutrition and Dietetics 2019 Global Nutrition Research and Policy Forum. J. Acad. Nutr. Diet. 2020, 120, 1407-1416.

58. Farooqui, A.A. Importance of fiber in human diet: Contribution of microbiota in human health. In Gut Microbiota in Neurologic and Visceral Diseases; Elsevier, 2021; pp. 5167.

59. Patel, S. Anti-Obesity and Anti-Diabetes Foods: High Fibre Diets. Encycl. Food Chem. 2019, 248-252.

60. Lee, P.; Yacyshyn, B.R.; Yacyshyn, M.B. Gut microbiota and obesity: An opportunity to alter obesity through faecal microbiota transplant (FMT). Diabetes, Obes. Metab. 2019, 21, 479-490.

61. Vellido-Perez, J.A.; Ochando-Pulido, J.M.; Brito-de la Fuente, E.; Martinez-Ferez, A. Novel emulsions-based technological approaches for the protection of omega-3 polyunsaturated fatty acids against oxidation processes - A comprehensive review. Food Struct. 2021, 27, 100175.

62. Jang, H.; Park, K. Omega-3 and omega-6 polyunsaturated fatty acids and metabolic syndrome: A systematic review and meta-analysis. Clin. Nutr. 2020, 39, 765-773.

63. Abdullah; Rehman, M.U.; Khan, F.; Niaz, K. Influence of omega-3 fatty acids and monounsaturated fats in liver diseases. In Influence of Nutrients, Bioactive Compounds, and Plant Extracts in Liver Diseases; Elsevier, 2021; pp. 161-174.

64. Kobyliak, N.; Falalyeyeva, T.; Mykhalchyshyn, G.; Molochek, N.; Savchuk, O.; Kyriienko, D.; Komisarenko, I. Probiotic and omega-3 polyunsaturated fatty acids supplementation reduces insulin resistance, improves glycemia and obesity parameters in individuals with type 2 diabetes: A randomised controlled trial. Obes. Med. 2020, 19, 100248.

65. Bellenger, J.; Bellenger, S.; Escoula, Q.; Bidu, C.; Narce, M. N-3 polyunsaturated fatty acids: An innovative strategy against obesity and related metabolic disorders, intestinal alteration and gut microbiota dysbiosis. Biochimie 2019, 159, 66-71.

66. Liu, Y.; Fang, H.; Liu, H.; Cheng, H.; Pan, L.; Hu, M.; Li, X. Goji berry juice fermented by probiotics attenuates dextran sodium sulfate-induced ulcerative colitis in mice. $J$. Funct. Foods 2021, 83, 104491.

67. De la Fuente, M.; Sánchez, C.; Vallejo, C.; Díaz-Del Cerro, E.; Arnalich, F.; Hernanz, Á. Vitamin $C$ and vitamin $C$ plus $E$ improve the immune function in the elderly. Exp. Gerontol. 2020, 142, 111118.

68. Lee, G.Y.; Han, S.N. The Role of Vitamin E in Immunity. Nutr. 2018, Vol. 10, Page 1614 2018, 10, 1614.

69. Namkhah, Z.; Ashtary-Larky, D.; Naeini, F.; Clark, C.C.T.; Asbaghi, O. Does vitamin C supplementation exert profitable effects on serum lipid profile in patients with type 2 diabetes? A systematic review and dose-response meta-analysis. Pharmacol. Res. 2021, 169, 105665.

70. Traber, M.G.; Buettner, G.R.; Bruno, R.S. The relationship between vitamin C status, the gut-liver axis, and metabolic syndrome. Redox Biol. 2019, 21, 101091. 
71. Trinidad-Calderón, P.A.; Acosta-Cruz, E.; Rivero-Masante, M.N.; Díaz-Gómez, J.L.; García-Lara, S.; López-Castillo, L.M. Maize bioactive peptides: From structure to human health. J. Cereal Sci. 2021, 100.

72. Udenigwe, C.C.; Abioye, R.O.; Okagu, I.U.; Obeme-Nmom, J.I. Bioaccessibility of bioactive peptides: recent advances and perspectives. Curr. Opin. Food Sci. 2021, 39, 182-189.

73. Chalamaiah, M.; Keskin Ulug, S.; Hong, H.; Wu, J. Regulatory requirements of bioactive peptides (protein hydrolysates) from food proteins. J. Funct. Foods 2019, 58, 123-129,

74. Vikøren, L.A.; Drotningsvik, A.; Midttun, $\varnothing$.; McCann, A.; Bergseth, M.T.; Austgulen, M.H.; Mellgren, G.; Ueland, P.M.; Gudbrandsen, O.A. Baked cod consumption delayed the development of kidney and liver dysfunction and affected amino acid concentrations, but did not affect blood pressure, blood glucose or liver triacylglycerol concentrations in obese fa/fa Zucker rats. Nutr. Res. 2021.

75. Doley, J. Vitamins and Minerals in Older Adults: Causes, Diagnosis, and Treatment of Deficiency; Elsevier Inc., 2017; ISBN 9780128092996.

76. Billington, E.O.; Bristow, S.M.; Gamble, G.D.; de Kwant, J.A.; Stewart, A.; Mihov, B. V.; Horne, A.M.; Reid, I.R. Acute effects of calcium supplements on blood pressure: randomised, crossover trial in postmenopausal women. Osteoporos. Int. 2017, 28, 119-125.

77. Porri, D.; Biesalski, H.K.; Limitone, A.; Bertuzzo, L.; Cena, H. Effect of magnesium supplementation on women's health and well-being. NFS J. 2021, 23, 30-36.

78. Verma, H.; Garg, R. Effect of magnesium supplementation on type 2 diabetes associated cardiovascular risk factors: a systematic review and meta-analysis. J. Hum. Nutr. Diet. 2017, 30, 621-633.

79. Asbaghi, O.; Moradi, S.; Nezamoleslami, S.; Moosavian, S.P.; Hojjati Kermani, M. ali; Lazaridi, A.V.; Miraghajani, M. The Effects of Magnesium Supplementation on Lipid Profile Among Type 2 Diabetes Patients: a Systematic Review and Meta-analysis of Randomized Controlled Trials. Biol. Trace Elem. Res. 2021, 199, 861-873.

80. Kim, J.; Yun, J.M.; Kim, M.K.; Kwon, O.; Cho, B. Lactobacillus gasseri BNR17 Supplementation Reduces the Visceral Fat Accumulation and Waist Circumference in Obese Adults: A Randomized, Double-Blind, Placebo-Controlled Trial. J. Med. Food 2018, 21, 454-461.

81. Guan, R.; Van Le, Q.; Yang, H.; Zhang, D.; Gu, H.; Yang, Y.; Sonne, C.; Lam, S.S.; Zhong, J.; Jianguang, Z.; et al. A review of dietary phytochemicals and their relation to oxidative stress and human diseases. Chemosphere 2021, 271, 129499.

82. Prashar, Y.; Patel, N.J. An in vitro approach to evaluate the anti-adipogenic effect of Myrica nagi Thunb. Fruit extract on 3T3-L1 adipocyte cell line. Obes. Med. 2020, 18.

83. Shatylo, V.; Antoniuk-Shcheglova, I.; Naskalova, S.; Bondarenko, O.; Havalko, A.; Krasnienkov, D.; Zabuga, O.; Kukharskyy, V.; Guryanov, V.; Vaiserman, A. Cardiometabolic benefits of quercetin in elderly patients with metabolic syndrome. PharmaNutrition 2021, 15, 100250.

84. Kim, J.H.; Lee, S.; Cho, E.J. molecules Flavonoids from Acer okamotoanum Inhibit Adipocyte Differentiation and Promote Lipolysis in the 3T3-L1 Cells.

85. Balusamy, S.R.; Veerappan, K.; Ranjan, A.; Kim, Y.J.; Chellappan, D.K.; Dua, K.; Lee, J.; Perumalsamy, H. Phyllanthus emblica fruit extract attenuates lipid metabolism in 3T3L1 adipocytes via activating apoptosis mediated cell death. Phytomedicine 2020, 66, 153129.

86. Guo, L.; Kang, J.S.; Kang, N.J.; Je, B. II; Lee, Y.J.; Park, Y.H.; Choi, Y.W. Pelargonidin suppresses adipogenesis in 3T3-L1 cells through inhibition of PPAR- $\gamma$ signaling pathway. Arch. Biochem. Biophys. 2020, 686, 108365.

87. Hartogh, D.J. Den; Vlavcheski, F.; Giacca, A.; Tsiani, E. Attenuation of Free Fatty Acid (FFA)-Induced Skeletal Muscle Cell Insulin Resistance by Resveratrol is Linked to Activation of AMPK and Inhibition of mTOR and p70 S6K. Int. J. Mol. Sci. 
$2020,21,14,4900$.

88. Wu, L.Y.; Chen, C.W.; Chen, L.K.; Chou, H.Y.; Chang, C.L.; Juan, C.C. Curcumin attenuates adipogenesis by inducing preadipocyte apoptosis and inhibiting adipocyte differentiation. Nutrients 2019, 11.

89. Torres-Villarreal, D.; Camacho, A.; Castro, H.; Ortiz-Lopez, R.; de la Garza, A.L. Antiobesity effects of kaempferol by inhibiting adipogenesis and increasing lipolysis in 3T3L1 cells. J. Physiol. Biochem. 2018751 2018, 75, 83-88.

90. Leng, E.; Xiao, Y.; Mo, Z.; Li, Y.; Zhang, Y.; Deng, X.; Zhou, M.; Zhou, C.; He, Z.; He, J.; et al. Synergistic effect of phytochemicals on cholesterol metabolism and lipid accumulation in HepG2 cells. BMC Complement. Altern. Med. 2018181 2018, 18, 110.

91. Lee, S.G.; Kim, J.S.; Min, K.; Kwon, T.K.; Nam, J.O. Hispidulin inhibits adipogenesis in 3T3-L1 adipocytes through PPAR p pathway. Chem. Biol. Interact. 2018, 293, 89-93.

92. Bae, J.; Kumazoe, M.; Fujimura, Y.; Tachibana, H. Diallyl disulfide potentiates antiobesity effect of green tea in high-fat/high-sucrose diet-induced obesity. J. Nutr. Biochem. 2019, 64, 152-161.

93. Dey, P.; Sasaki, G.Y.; Wei, P.; Li, J.; Wang, L.; Zhu, J.; McTigue, D.; Yu, Z.; Bruno, R.S. Green tea extract prevents obesity in male mice by alleviating gut dysbiosis in association with improved intestinal barrier function that limits endotoxin translocation and adipose inflammation. J. Nutr. Biochem. 2019, 67, 78-89.

94. Li, F.; Gao, C.; Yan, P.; Zhang, M.; Wang, Y.; Hu, Y.; Wu, X.; Wang, X.; Sheng, J. EGCG reduces obesity and white adipose tissue gain partly through AMPK activation in mice. Front. Pharmacol. 2018, 9, 1-9.

95. Karim, N.; Jia, Z.; Zheng, X.; Cui, S.; Chen, W. A recent review of citrus flavanone naringenin on metabolic diseases and its potential sources for high yield-production. Trends Food Sci. Technol. 2018, 79, 35-54.

96. Yang, M.; Jiang, Z. huan; Li, C. guang; Zhu, Y. juan; Li, Z.; Tang, Y. zhao; Ni, C. lin Apigenin prevents metabolic syndrome in high-fructose diet-fed mice by Keap1-Nrf2 pathway. Biomed. Pharmacother. 2018, 105, 1283-1290.

97. Moura, M.H.C.; Cunha, M.G.; Alezandro, M.R.; Genovese, M.I. Phenolic-rich jaboticaba (Plinia jaboticaba (Vell.) Berg) extracts prevent high-fat-sucrose diet-induced obesity in C57BL/6 mice. Food Res. Int. 2018, 107, 48-60.

98. Leverrier, A.; Daguet, D.; Calame, W.; Dhoye, P.; Kodimule, S.P. Helianthus annuus seed extract affects weight and body composition of healthy obese adults during 12 weeks of consumption: A randomized, double-blind, placebo-controlled pilot study. Nutrients 2019, 11, 1080.

99. Chew, B.; Mathison, B.; Kimble, L.; McKay, D.; Kaspar, K.; Khoo, C.; Chen, C.-Y.O.; Blumberg, J. Chronic consumption of a low calorie, high polyphenol cranberry beverage attenuates inflammation and improves glucoregulation and HDL cholesterol in healthy overweight humans: a randomized controlled trial. Eur. J. Nutr. 2019, 58, 1223-1235.

100. Ponce, O.; Benassi, R.; Cesar, T. Orange juice associated with a balanced diet mitigated risk factors of metabolic syndrome: A randomized controlled trial. J. Nutr. Intermed. Metab. 2019, 17, 100101.

101. Elkahoui, S.; Levin, C.E.; Bartley, G.E.; Yokoyama, W.; Friedman, M. Levels of Fecal Procyanidins and Changes in Microbiota and Metabolism in Mice Fed a High-Fat Diet Supplemented with Apple Peel. J. Agric. Food Chem. 2019, 67, 10352-10360.

102. Terzo, S.; Caldara, G.F.; Ferrantelli, V.; Puleio, R.; Cassata, G.; Mulè, F.; Amato, A. Pistachio Consumption Prevents and Improves Lipid Dysmetabolism by Reducing the Lipid Metabolizing Gene Expression in Diet-Induced Obese Mice. Nutr. 2018, Vol. 10, Page 1857 2018, 10, 1857.

103. Huang, L.-H.; Liu, C.-Y.; Wang, L.-Y.; Huang, C.-J.; Hsu, C.-H. Effects of green tea extract on overweight and obese women with high levels of low density-lipoproteincholesterol (LDL-C): a randomised, double-blind, and cross-over placebo-controlled 
clinical trial. BMC Complement. Altern. Med. 2018, 18, 294.

104. Dixit, K.; Kamath, D. V.; Alluri, K. V.; Davis, B.A. Efficacy of a novel herbal formulation for weight loss demonstrated in a 16-week randomized, double-blind, placebocontrolled clinical trial with healthy overweight adults. Diabetes, Obes. Metab. 2018, 20, 2633-2641.

105. Del Bo', C.; Bernardi, S.; Cherubini, A.; Porrini, M.; Gargari, G.; Hidalgo-Liberona, N.; González-Domínguez, R.; Zamora-Ros, R.; Peron, G.; Marino, M.; et al. A polyphenolrich dietary pattern improves intestinal permeability, evaluated as serum zonulin levels, in older subjects: The MaPLE randomised controlled trial. Clin. Nutr. 2021, 40, 3006-3018.

106. Hibi, M.; Takase, H.; Iwasaki, M.; Osaki, N.; Katsuragi, Y. Efficacy of tea catechin-rich beverages to reduce abdominal adiposity and metabolic syndrome risks in obese and overweight subjects: a pooled analysis of 6 human trials. Nutr. Res. 2018, 55, 1-10.

107. Toscano, L.T.; Silva, A.S.; Toscano, L.T.; Tavares, R.L.; Biasoto, A.C.T.; de Camargo, A.C.; da Silva, C.S.O.; Gonçalves, M. da C.R.; Shahidi, F. Phenolics from purple grape juice increase serum antioxidant status and improve lipid profile and blood pressure in healthy adults under intense physical training. J. Funct. Foods 2017, 33, 419-424.

108. Les, F.; Carpéné, C.; Arbonés-Mainar, J.M.; Decaunes, P.; Valero, M.S.; López, V. Pomegranate juice and its main polyphenols exhibit direct effects on amine oxidases from human adipose tissue and inhibit lipid metabolism in adipocytes. J. Funct. Foods 2017, 33, 323-331.

109. Brüll, V.; Burak, C.; Stoffel-Wagner, B.; Wolffram, S.; Nickenig, G.; Müller, C.; Langguth, P.; Alteheld, B.; Fimmers, R.; Naaf, S.; et al. Effects of a quercetin-rich onion skin extract on $24 \mathrm{~h}$ ambulatory blood pressure and endothelial function in overweight-to-obese patients with (pre-)hypertension: A randomised double-blinded placebo-controlled cross-over trial. Br. J. Nutr. 2015, 114, 1263-1277.

110. Paola Forero, D.; Masatani, C.; Fujimoto, Y.; Coy-Barrera, E.; G. Peterson, D.; Osorio, C. Spermidine Derivatives in Lulo (Solanum quitoense Lam.) Fruit: Sensory (Taste) versus Biofunctional (ACE-Inhibition) Properties. J. Agric. Food Chem. 2016, 64, 5375-5383.

111. de Simone, C. The Unregulated Probiotic Market. Clin. Gastroenterol. Hepatol. 2019, 17, 809-817.

112. FAO/WHO, Guidelines for the evaluation of probiotics in food. Food and Agriculture Organization of the United Nations World Health Organization Working Group. 2006 Available http://www.fao.org/publications/card/es/c/7c102d95-2fd5-5b22-8faff0b2e68dfbb6/ (Accessed on Jul 24, 2021).

113. Raman, M.; Ambalam, P.; Doble, M. Probiotics, prebiotics, and fibers in nutritive and functional beverages. In Nutrients in Beverages: Volume 12: The Science of Beverages; Elsevier, 2019; pp. 315-367 ISBN 9780128168424.

114. Reque, P.M.; Brandelli, A. Encapsulation of probiotics and nutraceuticals: Applications in functional food industry. Trends Food Sci. Technol. 2021, 114, 1-10.

115. Koirala, S.; Anal, A.K. Probiotics-based foods and beverages as future foods and their overall safety and regulatory claims. Futur. Foods 2021, 3, 100013.

116. WGO Probiotics and Prebiotics. World Gastroenterology Organisation.2021 Available online: https://www.worldgastroenterology.org/guidelines/globalguidelines/probiotics-and-prebiotics (accessed on Aug 28, 2021).

117. BBC Probiotics Market Report on Dietary Supplements and Animal Feed Available online: https://www.bccresearch.com/market-research/food-andbeverage/probiotics-market-ingredients-supplements-foods-report.html (accessed on Aug 28, 2021).

118. Song, E.-J.; Han, K.; Lim, T.-J.; Lim, S.; Chung, M.-J.; Nam, M.H.; Kim, H.; Nam, Y.-D. Effect of probiotics on obesity-related markers per enterotype: a double-blind, placebo-controlled, randomized clinical trial. EPMA J. 2020111 2020, 11, 31-51.

119. Soleimani, A.; Zarrati Mojarrad, M.; Bahmani, F.; Taghizadeh, M.; Ramezani, M.; 
Tajabadi-Ebrahimi, M.; Jafari, P.; Esmaillzadeh, A.; Asemi, Z. Probiotic supplementation in diabetic hemodialysis patients has beneficial metabolic effects. Kidney Int. 2017, 91, 435-442.

120. Tilg, H.; Moschen, A.R. Microbiota and diabetes: An evolving relationship. Gut 2014, 63, 1513-1521.

121. Sáez-Lara, M.J.; Robles-Sanchez, C.; Ruiz-Ojeda, F.J.; Plaza-Diaz, J.; Gil, A. Effects of probiotics and synbiotics on obesity, insulin resistance syndrome, type 2 diabetes and non-alcoholic fatty liver disease: A review of human clinical trials. Int. J. Mol. Sci. 2016, 17, 1-15.

122. Kim, S.; Joung, J.Y.; Kang, D.; Oh, N.S.; Yoon, Y. Anti-obesity effects of Lactobacillus rhamnosus 4B15, and its synergy with hydrolysed lactose skim milk powder. Int. Dairy J. 2021, 104997.

123. Molina-Tijeras, J.A.; Diez-Echave, P.; Vezza, T.; Hidalgo-García, L.; Ruiz-Malagón, A.J.; Rodríguez-Sojo, M.J.; Romero, M.; Robles-Vera, I.; García, F.; Plaza-Diaz, J.; et al. Lactobacillus fermentum CECT5716 ameliorates high fat diet-induced obesity in mice through modulation of gut microbiota dysbiosis. Pharmacol. Res. 2021, 167, 105471.

124. Zhang, J.; Wang, S.; Zeng, Z.; Qin, Y.; Shen, Q.; Li, P. Anti-diabetic effects of Bifidobacterium animalis 01 through improving hepatic insulin sensitivity in type 2 diabetic rat model. J. Funct. Foods 2020, 67, 103843.

125. Li, X.; Huang, Y.; Song, L.; Xiao, Y.; Lu, S.; Xu, J.; Li, J.; Ren, Z. Lactobacillus plantarum prevents obesity via modulation of gut microbiota and metabolites in high-fat feeding mice. J. Funct. Foods 2020, 73, 104103.

126. Castro-Rodríguez, D.C.; Reyes-Castro, L.A.; Vega, C.C.; Rodríguez-González, G.L.; YáñezFernández, J.; Zambrano, E. Leuconostoc mesenteroides subsp. mesenteroides SD23 Prevents Metabolic Dysfunction Associated with High-Fat Diet-Induced Obesity in Male Mice. Probiotics Antimicrob. Proteins 2019122 2019, 12, 505-516.

127. Soundharrajan, I.; Kuppusamy, P.; Srisesharam, S.; Lee, J.C.; Sivanesan, R.; Kim, D.; Choi, K.C. Positive metabolic effects of selected probiotic bacteria on diet-induced obesity in mice are associated with improvement of dysbiotic gut microbiota. FASEB J. 2020, 34, 12289-12307.

128. Park, J.E.; Oh, S.H.; Cha, Y.S. Lactobacillus brevis OPK-3 from kimchi prevents obesity and modulates the expression of adipogenic and pro-inflammatory genes in adipose tissue of diet-induced obese mice. Nutrients 2020, 12.

129. Wang, M.; Zhang, B.; Hu, J.; Nie, S.; Xiong, T.; Xie, M. Intervention of five strains of Lactobacillus on obesity in mice induced by high-fat diet. J. Funct. Foods 2020, 72, 104078.

130. Won, S.M.; Chen, S.; Lee, S.Y.; Lee, K.E.; Park, K.W.; Yoon, J.H. Lactobacillus sakei adm14 induces anti-obesity effects and changes in gut microbiome in high-fat diet-induced obese mice. Nutrients 2020, 12, 1-17.

131. Jang, H.-M.; Han, S.-K.; Kim, J.-K.; Oh, S.-J.; Jang, H.-B.; Kim, D.-H. Lactobacillus sakei Alleviates High-Fat-Diet-Induced Obesity and Anxiety in Mice by Inducing AMPK Activation and SIRT1 Expression and Inhibiting Gut Microbiota-Mediated NF-KB Activation. Mol. Nutr. Food Res. 2019, 63, 1800978.

132. Lee, E.; Jung, S.-R.; Lee, S.-Y.; Lee, N.-K.; Paik, H.-D.; Lim, S.-I. Lactobacillus plantarum Strain Ln4 Attenuates Diet-Induced Obesity, Insulin Resistance, and Changes in Hepatic mRNA Levels Associated with Glucose and Lipid Metabolism. Nutr. 2018, Vol. 10, Page 643 2018, 10, 643.

133. Chen, L.H.; Chen, Y.H.; Cheng, K.C.; Chien, T.Y.; Chan, C.H.; Tsao, S.P.; Huang, H.Y. Antiobesity effect of Lactobacillus reuteri 263 associated with energy metabolism remodeling of white adipose tissue in high-energy-diet-fed rats. J. Nutr. Biochem. 2018, 54, 87-94.

134. Zhang, X. lei; Wu, Y. feng; Wang, Y. shan; Wang, X. zhe; Piao, C. hong; Liu, J. mei; Liu, Y. long; Wang, Y. hua The protective effects of probiotic-fermented soymilk on high-fat 
diet-induced hyperlipidemia and liver injury. J. Funct. Foods 2017, 30, 220-227.

135. Qiao, Y.; Sun, J.; Xia, S.; Li, L.; Li, Y.; Wang, P.; Shi, Y.; Le, G. Effects of different Lactobacillus reuteri on inflammatory and fat storage in high-fat diet-induced obesity mice model. J. Funct. Foods 2015, 14, 424-434.

136. Ghizi, A.C. da S.; de Almeida Silva, M.; Moraes, F.S. de A.; da Silva, C.L.; Endringer, D.C.; Scherer, R.; Lenz, D.; de Lima, E.M.; Brasil, G.A.; Maia, J.F.; et al. Kefir improves blood parameters and reduces cardiovascular risks in patients with metabolic syndrome. PharmaNutrition 2021, 16, 100266.

137. Angelino, D.; Martina, A.; Rosi, A.; Veronesi, L.; Antonini, M.; Mennella, I.; Vitaglione, P.; Grioni, S.; Brighenti, F.; Zavaroni, I.; et al. Glucose- A nd Lipid-Related Biomarkers Are Affected in Healthy Obese or Hyperglycemic Adults Consuming a Whole-Grain Pasta Enriched in Prebiotics and Probiotics: A 12-Week Randomized Controlled Trial. J. Nutr. 2019, 149, 1714-1723.

138. Sperry, M.F.; Silva, H.L.A.; Balthazar, C.F.; Esmerino, E.A.; Verruck, S.; Prudencio, E.S.; Neto, R.P.C.; Tavares, M.I.B.; Peixoto, J.C.; Nazzaro, F.; et al. Probiotic Minas Frescal cheese added with L. casei 01: Physicochemical and bioactivity characterization and effects on hematological/biochemical parameters of hypertensive overweighted women - A randomized double-blind pilot trial. J. Funct. Foods 2018, 45, 435-443.

139. Bernini, L.J.; Simão, A.N.C.; Alfieri, D.F.; Lozovoy, M.A.B.; Mari, N.L.; de Souza, C.H.B.; Dichi, I.; Costa, G.N. Beneficial effects of Bifidobacterium lactis on lipid profile and cytokines in patients with metabolic syndrome: A randomized trial. Effects of probiotics on metabolic syndrome. Nutrition 2016, 32, 716-719.

140. Zarrati, M.; Salehi, E.; Nourijelyani, K.; Mofid, V.; Zadeh, M.J.H.; Najafi, F.; Ghaflati, Z.; Bidad, K.; Chamari, M.; Karimi, M.; et al. Effects of Probiotic Yogurt on Fat Distribution and Gene Expression of Proinflammatory Factors in Peripheral Blood Mononuclear Cells in Overweight and Obese People with or without Weight-Loss Diet. J. Am. Coll. Nutr. 2014, 33, 417-425.

141. Sanchez, M.; Darimont, C.; Drapeau, V.; Emady-Azar, S.; Lepage, M.; Rezzonico, E.; Ngom-Bru, C.; Berger, B.; Philippe, L.; Ammon-Zuffrey, C.; et al. Effect of Lactobacillus rhamnosus CGMCC1.3724 supplementation on weight loss and maintenance in obese men and women. Br. J. Nutr. 2014, 111, 1507-1519.

142. Alarcón-Urrutia, L.F. Análisis del referencial de las políticas públicas sobre prevención de la obesidad infantil en Colombia, 2017. Tesis de maestría. Universidad Nacional de Colombia.

143. Brennan, L.; Langley, S.; Verghese, K.; Lockrey, S.; Ryder, M.; Francis, C.; Phan-Le, N.T.; Hill, A. The role of packaging in fighting food waste: A systematised review of consumer perceptions of packaging. J. Clean. Prod. 2021, 281, 125276.

144. Kowalska, A.; Manning, L. Using the rapid alert system for food and feed: potential benefits and problems on data interpretation Aleksandra Kowalska and Louise Manning Using the rapid alert system for food and feed: potential benefits and problems on data interpretation. 2021, 61,6, 906-919.

145. FAO, Food Waste.United National Environment Programa. Index Report 2021 vailable online: http://www.fao.org/platform-food-loss waste/resources/detail/en/c/1378978/. (accessed on Jul 29,2020)

146. Moraes, N.V.; Lermen, F.H.; Echeveste, M.E.S. A systematic literature review on food waste/loss prevention and minimization methods. J. Environ. Manage. 2021, 286, 112268.

147. Caldeira, C.; De Laurentiis, V.; Corrado, S.; van Holsteijn, F.; Sala, S. Quantification of food waste per product group along the food supply chain in the European Union: a mass flow analysis. Resour. Conserv. Recycl. 2019, 149, 479-488.

148. FAO, News Article: As more go hungry and malnutrition persists, achieving Zero Hunger by 2030 in doubt, UN report warns Available online: http://www.fao.org/news/story/en/item/1297810/icode/ (accessed on Aug 29, 2021). 
149. Sharma, P.; Gaur, V.K.; Kim, S.H.; Pandey, A. Microbial strategies for bio-transforming food waste into resources. Bioresour. Technol. 2020, 299, 122580.

150. Machado, A.P. da F.; Geraldi, M.V.; do Nascimento, R. de P.; Moya, A.M.T.M.; Vezza, T.; Diez-Echave, P.; Gálvez, J.J.; Cazarin, C.B.B.; Maróstica Júnior, M.R. Polyphenols from food by-products: An alternative or complementary therapy to IBD conventional treatments. Food Res. Int. 2021, 140, 110018.

151. Verma, D.K.; Patel, A.R.; Thakur, M.; Singh, S.; Tripathy, S.; Srivastav, P.P.; ChávezGonzález, M.L.; Gupta, A.K.; Aguilar, C.N. A review of the composition and toxicology of fructans, and their applications in foods and health. J. Food Compos. Anal. 2021, 99, 103884.

152. Cádiz-Gurrea, M. de la L.; Villegas-Aguilar, M. del C.; Leyva-Jiménez, F.J.; PimentelMoral, S.; Fernández-Ochoa, Á.; Alañón, M.E.; Segura-Carretero, A. Revalorization of bioactive compounds from tropical fruit by-products and industrial applications by means of sustainable approaches. Food Res. Int. 2020, 138, 109786.

153. Ruiz Rodríguez, L.G.; Zamora Gasga, V.M.; Pescuma, M.; Van Nieuwenhove, C.; Mozzi, F.; Sánchez Burgos, J.A. Fruits and fruit by-products as sources of bioactive compounds. Benefits and trends of lactic acid fermentation in the development of novel fruit-based functional beverages. Food Res. Int. 2021, 140, 109854.

154. Sharma, P.; Gaur, V.K.; Sirohi, R.; Varjani, S.; Hyoun Kim, S.; Wong, J.W.C. Sustainable processing of food waste for production of bio-based products for circular bioeconomy. Bioresour. Technol. 2021, 325, 124684.

155. Sánchez-Camargo, A. del P.; Ballesteros-Vivas, D.; Buelvas-Puello, L.M.; MartinezCorrea, H.A.; Parada-Alfonso, F.; Cifuentes, A.; Ferreira, S.R.S.; Gutiérrez, L.F. Microwave-assisted extraction of phenolic compounds with antioxidant and antiproliferative activities from supercritical $\mathrm{CO} 2$ pre-extracted mango peel as valorization strategy. LWT 2021, 137, 110414.

156. Cascaes Teles, A.S.; Hidalgo Chávez, D.W.; Zarur Coelho, M.A.; Rosenthal, A.; Fortes Gottschalk, L.M.; Tonon, R.V. Combination of enzyme-assisted extraction and high hydrostatic pressure for phenolic compounds recovery from grape pomace. J. Food Eng. 2020, 288, 110128.

157. Carvalho Gualberto, N.; Santos de Oliveira, C.; Pedreira Nogueira, J.; Silva de Jesus, M.; Caroline Santos Araujo, H.; Rajan, M.; Terezinha Santos Leite Neta, M.; Narain, N. Bioactive compounds and antioxidant activities in the agro-industrial residues of acerola (Malpighia emarginata L.), guava (Psidium guajava L.), genipap (Genipa americana L.) and umbu (Spondias tuberosa L.) fruits assisted by ultrasonic or shaker extraction. Food Res. Int. 2021, 147, 110538,.

158. Araujo, R.G.; Rodríguez-Jasso, R.M.; Ruíz, H.A.; Govea-Salas, M.; Pintado, M.; Aguilar, C.N. Recovery of bioactive components from avocado peels using microwave-assisted extraction. Food Bioprod. Process. 2021, 127, 152-161.

159. Meregalli, M.M.; Puton, B.M.S.; Camera, F.D.M.; Amaral, A.U.; Zeni, J.; Cansian, R.L.; Mignoni, M.L.; Backes, G.T. Conventional and ultrasound-assisted methods for extraction of bioactive compounds from red araçá peel (Psidium cattleianum Sabine). Arab. J. Chem. 2020, 13, 5800-5809.

160. Figueroa, J.G.; Borrás-Linares, I.; Del Pino-García, R.; Curiel, J.A.; Lozano-Sánchez, J.; Segura-Carretero, A. Functional ingredient from avocado peel: Microwave-assisted extraction, characterization and potential applications for the food industry. Food Chem. 2021, 352, 129300.

161. García, P.; Fredes, C.; Cea, I.; Lozano-Sánchez, J.; Leyva-Jiménez, F.J.; Robert, P.; Vergara, C.; Jimenez, P. Recovery of bioactive compounds from pomegranate (Punica granatum I.) peel using pressurized liquid extraction. Foods 2021, 10, 203.

162. Jia, M.Z.; Fu, X.Q.; Deng, L.; Li, Z.L.; Dang, Y.Y. Phenolic extraction from grape (Vitis vinifera) seed via enzyme and microwave co-assisted salting-out extraction. Food Biosci. 2021, 40, 100919. 
163. dos Santos, L.C.; Johner, J.C.F.; Scopel, E.; Pontes, P.V.A.; Ribeiro, A.P.B.; Zabot, G.L.; Batista, E.A.C.; Meireles, M.A.A.; Martínez, J. Integrated supercritical CO2 extraction and fractionation of passion fruit (Passiflora edulis Sims) by-products. J. Supercrit. Fluids 2021, 168, 105093.

164. Rakshit, M.; Srivastav, P.P.; Bhunia, K. Kinetic modeling of ultrasonic-assisted extraction of punicalagin from pomegranate peel. J. Food Process Eng. 2020, 43, e13533.

165. Guthrie, F.; Wang, Y.; Neeve, N.; Quek, S.Y.; Mohammadi, K.; Baroutian, S. Recovery of phenolic antioxidants from green kiwifruit peel using subcritical water extraction. Food Bioprod. Process. 2020, 122, 136-144.

166. de Andrade Lima, M.; Charalampopoulos, D.; Chatzifragkou, A. Optimisation and modelling of supercritical $\mathrm{CO} 2$ extraction process of carotenoids from carrot peels. $J$. Supercrit. Fluids 2018, 133, 94-102.

167. Erşan, S.; Güçlü Üstündağ, Ö.; Carle, R.; Schweiggert, R.M. Determination of pistachio (Pistacia vera L.) hull (exo- and mesocarp) phenolics by HPLC-DAD-ESI/MSn and UHPLCDAD-ELSD after ultrasound-assisted extraction. J. Food Compos. Anal. 2017, 62, 103114.

168. Kumari, B.; Tiwari, B.K.; Hossain, M.B.; Rai, D.K.; Brunton, N.P. Ultrasound-assisted extraction of polyphenols from potato peels: profiling and kinetic modelling. Int. J. Food Sci. Technol. 2017, 52, 1432-1439.

169. M'hiri, N.; Ioannou, I.; Mihoubi Boudhrioua, N.; Ghoul, M. Effect of different operating conditions on the extraction of phenolic compounds in orange peel. Food Bioprod. Process. 2015, 96, 161-170.

170. Mateos-Aparicio, I.; Matias, A. Food industry processing by-products in foods. In The Role of Alternative and Innovative Food Ingredients and Products in Consumer Wellness; Elsevier, 2019; pp. 239-281.

171. Struck, S.; Rohm, H. Fruit processing by-products as food ingredients. In Valorization of Fruit Processing By-products; Elsevier, 2020; pp. 1-16.

172. Ben-Othman, S.; Jõudu, I.; Bhat, R. Bioactives from agri-food wastes: Present insights and future challenges. Molecules 2020, 25, 510.

173. Fito, P.; Pastor, R. Non-diffusional mechanisms occurring during vacuum osmotic dehydration. J. Food Eng. 1994, 21, 513-519.

174. Fito, P.; Chiralt, A.; Betoret, N.; Gras, M.; Cháfer, M.; Martínez-Monzó, J.; Andrés, A.; Vidal, D. Vacuum impregnation and osmotic dehydration in matrix engineering: Application in functional fresh food development. J. Food Eng. 2001, 49, 175-183.

175. Zhao, X.; Zhou, Y.; Zhao, L.; Chen, L.; He, Y.; Yang, H. Vacuum impregnation of fish gelatin combined with grape seed extract inhibits protein oxidation and degradation of chilled tilapia fillets. Food Chem. 2019, 294, 316-325.

176. Abalos, R.A.; Naef, E.F.; Aviles, M.V.; Gómez, M.B. Vacuum impregnation: A methodology for the preparation of a ready-to-eat sweet potato enriched in polyphenols. LWT 2020, 131, 109773.

177. Hironaka, K.; Kikuchi, M.; Koaze, H.; Sato, T.; Kojima, M.; Yamamoto, K.; Yasuda, K.; Mori, M.; Tsuda, S. Ascorbic acid enrichment of whole potato tuber by vacuumimpregnation. Food Chem. 2011, 127, 1114-1118.

178. Ester, B.; Noelia, B.; Laura, C.J.; Francesca, P.; Cristina, B.; Rosalba, L.; Marco, D.R. Probiotic survival and in vitro digestion of $L$. salivarius spp. salivarius encapsulated by high homogenization pressures and incorporated into a fruit matrix. LWT 2019, 111, 883-888.

179. Castagnini, J.M.; Betoret, N.; Betoret, E.; Fito, P. Vacuum impregnation and air drying temperature effect on individual anthocyanins and antiradical capacity of blueberry juice included into an apple matrix. LWT - Food Sci. Technol. 2015, 64, 1289-1296.

180. Waghmare, R.B.; Perumal, A.B.; Moses, J.A.; Anandharamakrishnan, C. Recent Developments in Freeze Drying of Foods. In Innovative Food Processing Technologies; 
Elsevier, 2021; pp. 82-99.

181. Mesa, J.; Hinestroza-Córdoba, L.I.; Barrera, C.; Seguí, L.; Betoret, E.; Betoret, N. High homogenization pressures to improve food quality, functionality and sustainability. Molecules 2020, 25,14,3305

182. Betoret, E.; Betoret, N.; Arilla, A.; Bennár, M.; Barrera, C.; Codoñer, P.; Fito, P. No invasive methodology to produce a probiotic low humid apple snack with potential effect against Helicobacter pylori. J. Food Eng 2012; 110, 289-293.

183. Quan, W.; Tao, Y.; Qie, X.; Zeng, M.; Qin, F.; Chen, J.; He, Z. Effects of high-pressure homogenization, thermal processing, and milk matrix on the in vitro bioaccessibility of phenolic compounds in pomelo and kiwi juices. J. Funct. Foods 2020, 64, 103633.

184. Stinco, C.M.; Sentandreu, E.; Mapelli-Brahm, P.; Navarro, J.L.; Vicario, I.M.; MeléndezMartínez, A.J. Influence of high pressure homogenization and pasteurization on the in vitro bioaccessibility of carotenoids and flavonoids in orange juice. Food Chem. 2020, $331,127259$.

185. Betoret, E.; Sentandreu, E.; Betoret, N.; Codoñer-Franch, P.; Valls-Bellés, V.; Fito, P. Technological development and functional properties of an apple snack rich in flavonoid from mandarin juice. Innov. Food Sci. Emerg. Technol. 2012, 16, 298-304.

186. Mustafa, S.M.; Chua, L.S. Green technological fermentation for probioticated beverages for health enhancement. In Biotechnological Progress and Beverage Consumption: Volume 19: The Science of Beverages; Elsevier, 2019; pp. 407-434 ISBN 9780128166789.

187. Xiang, H.; Sun-Waterhouse, D.; Waterhouse, G.I.N.; Cui, C.; Ruan, Z. Fermentationenabled wellness foods: A fresh perspective. Food Sci. Hum. Wellness 2019, 8, 203243.

188. Panghal, A.; Janghu, S.; Virkar, K.; Gat, Y.; Kumar, V.; Chhikara, N. Potential non-dairy probiotic products - A healthy approach. Food Biosci. 2018, 21, 80-89. 


\section{OBJETIVOS Y PLAN DE TRABAJO}




\subsection{Justificación e interés de la tesis doctoral}

La tesis doctoral se ha desarrollado en la Universitat Politècnica de València en el marco del proyecto titulado: "Fortalecimiento de los Encadenamientos Productivos de las Subregiones del Chocó- Colombia (Alto Atrato, Medio Atrato, Bajo Atrato, Litoral del Pacífico y San Juan)" BPIN 2013000100284 ejecutado por la Universidad Tecnológica del Chocó. El proyecto ha sido financiado con Recursos del Sistema General de Regalías del Departamento del Chocó y aprobado para la ejecución entre los años 2014 y 2021.

Este proyecto parte del conocimiento que expone la Comisión Regional de Competitividad y el Plan de Desarrollo Nacional en su Pilar III: Crecimiento sostenible y competitividad: un nuevo Chocó para vivir con seguridad humana y ambiental. Se trata de promover acciones dirigidas a un uso sostenible de los recursos naturales y a la aplicación de nuevas tecnologías. Se enmarca en el Plan Regional de Competitividad del Chocó, que está integrado en el Plan Estratégico Regional de Ciencia, Tecnología e Innovación "PERCTI Chocó Bioinnovador y Sustentable" y en el Plan Estratégico de Emprendimiento Regional.

El objetivo principal es incrementar el nivel de desarrollo tecnológico e innovación en las cadenas productivas priorizadas de las subregiones del departamento del Chocó. Para ello propone acciones dirigidas a: i) desarrollar mecanismos de articulación y apropiación social de ciencia, tecnología y la innovación; ii) Para ello propone acciones dirigidas a i) Identificar los distintos niveles de articulación, desarrollo tecnológico e innovación en los encadenamientos productivos del departamento y proponer estrategias para su desarrollo; ii) elevar el nivel de organización de los productores y empresas en las cadenas priorizadas; iii) incrementar los recursos económicos para el desarrollo de actividades de Ciencia, Tecnología e innovación (CTI y iv) implementar estrategias de difusión de la información pertinente a las cadenas productivas (lulo, plátano, piña y borojó).

En Colombia, las frutas tropicales juegan un papel importante en la promoción de una dieta saludable ya que constituyen una fuente natural de vitaminas, fibra y otros compuestos bioactivos con efecto beneficioso para la salud humana. Ya se ha visto en el apartado de Introducción que el lulo (Solanum quitoense Lam) es una de las frutas tropicales de mayor interés por 
su color, sabor y aroma, y con propiedades excepcionales para el procesamiento industrial. Además, posee un excelente valor nutricional, siendo fuente importante de vitamina C, minerales, fibra, compuestos polifenólicos, carotenoides y aminas bioactivas como la espermidina. Dada su estacionalidad y sus limitadas opciones de industrialización, cada año se desperdicia un alto porcentaje de la producción. Se trata de fruta con propiedades adecuadas para ser utilizada en el desarrollo de productos medianamente procesados que podrían diseñarse con el objetivo de paliar los problemas de desnutrición en la población infantil y los principales desórdenes fisiológicos (obesidad e hipertensión) que afectan a la población adulta del departamento del Chocó. De esta forma sería posible aprovechar los recursos autóctonos y reducir el desperdicio para obtener alimentos más nutritivos y saludables que ayuden en la prevención de las enfermedades no transmisibles, contribuyendo a los ODS 2, 3 y 12.

En la obtención de los productos medianamente procesados a partir del fruto del lulo se plantea la aplicación de tecnologías sostenibles y/o innovadoras que garanticen la estabilidad de sus compuestos bioactivos y que permitan incluir otros, como los prebióticos, de una forma controlada.

En este sentido, la técnica de impregnación a vacío (IV) ha sido probada como una tecnología efectiva para enriquecer frutas porosas con adecuada capacidad de impregnación sin la necesidad de aplicar temperaturas altas y manteniendo las propiedades estructurales, nutritivas y sensoriales de la fruta fresca.

La tecnología de las altas presiones de homogenización (HPH) es una tecnología no térmica que podría utilizarse para la obtención de un zumo de elevada calidad que conservara parte de la pulpa y asegurara una mayor biodisponibilidad de los componentes bioactivos de la fruta fresca. Además, podría realizarse la incorporación de probióticos al zumo desarrollando un alimento no lácteo con probióticos y perfil nutricional mejorado.

Por último, la técnica de secado por aire caliente (SAC), ampliamente extendida y con un coste relativamente bajo podría utilizarse para el aprovechamiento del bagazo resultante del proceso de obtención del zumo. La deshidratación en condiciones controladas junto con la operación de triturado, permitirían obtener un producto en polvo rico en fibra $y$ carotenoides que podría ser utilizado como ingrediente por la industria 
alimentaria para aumentar el contenido en fibra y carotenoides de productos procesados.

Las razones expuestas anteriormente permiten definir la siguiente hipótesis de partida:

Es posible contribuir a la mejora del estado nutricional y de salud de la población del departamento de Chocó mediante la formulación y el desarrollo de productos que aprovechen materias primas autóctonas y de valor funcional.

\subsection{Objetivos}

El objetivo general que se plantea en esta tesis doctoral es:

Desarrollar productos medianamente procesados a partir del fruto del lulo mediante la aplicación de tecnologías sostenibles y/o innovadoras que garanticen la estabilidad de sus compuestos bioactivos y que permitan incluir otros, como los probióticos, de una forma controlada. Los productos irán dirigidos a la población adulta con problemas de obesidad e hipertensión y a la población infantil con problemas de desnutrición del departamento del Chocó (Colombia).

Para la consecución de este objetivo general se plantean los siguientes objetivos específicos:

1.1. Identificar las principales deficiencias nutricionales que afectan a la población infantil chocoana. Establecer las principales necesidades de suplementación.

1.2. Conocer los principales compuestos bioactivos y los microorganismos probióticos con efecto probado sobre la obesidad y la hipertensión.

1.3. Entender como la tecnología de las altas presiones de homogenización (HPH) puede contribuir a la mejora de la calidad y la funcionalidad de los alimentos y a la sostenibilidad de los sistemas alimentarios.

1.4. Conocer las características estructurales, fisicoquímicas y funcionales del fruto del lulo. Evaluar la respuesta a la operación de impregnación a vacío.

1.5. Determinar el efecto de las HPH sobre las propiedades fisicoquímicas y 
funcionales del zumo de lulo. Establecer el efecto del nivel de presión sobre el perfil de compuestos fenólicos.

1.6. Establecer las posibilidades de crecimiento de una cepa probiótica con efecto sobre la obesidad en zumo de lulo. Determinar las posibilidades de mejora de la viabilidad rectificando el $\mathrm{pH}$ y/o homogeneizando el zumo a diferentes presiones.

1.7. Determinar el efecto del crecimiento de la cepa probiótico sobre las propiedades antioxidantes del zumo de lulo homogeneizado a diferentes presiones y sin homogeneizar.

1.8. Determinar la resistencia a la digestión gastrointestinal in vitro de la cepa probiótico incorporada al zumo homogeneizado a diferentes presiones y sin homogeneizar.

1.9. Conocer las propiedades fisicoquímicas, la capacidad antiradical y el contenido en fibra y carotenoides del bagazo resultante del proceso de obtención de zumo de lulo.

1.10. Determinar el efecto de las condiciones de secado y triturado sobre las propiedades fisicoquímicas, la capacidad antiradical y el contenido en fibra y carotenoides de un polvo obtenido a partir del bagazo de lulo.

1.11. Determinar el efecto del nivel de triturado sobre las propiedades de interacción con el agua y el aceite de un polvo obtenido a partir del bagazo de lulo. Establecer las principales aplicaciones como ingrediente de la industria alimentaria.

\subsection{Plan de trabajo}

A continuación, se detalla el plan de trabajo:

En las figuras $2.1,2.2$ y 2.3 se han esquematizado en forma de diagrama de flujo las principales actividades de laboratorio.

1. Valoración nutricional de un grupo representativo de niños con edad comprendida entre los 2 y los 5 años de la zona urbana de Quibdó.

a. Descripción del área y de la población objeto de estudio 
b. Sensibilización y obtención de la información

c. Tratamiento de los resultados de las encuestas

d. Diseño de un instrumento para recolección de la información basado en preguntas cerradas relacionadas con los hábitos de consumo de la población objeto de estudio

2. Revisión bibliográfica sobre los componentes bioactivos y los microorganismos probióticos con efecto probado sobre la obesidad y la hipertensión.

3. Revisión bibliográfica sobre las aplicaciones de las HPH para la mejora de la calidad, la funcionalidad y la sostenibilidad.

4. Caracterización fisicoquímica, estructural y funcional del fruto del lulo. Determinación de la respuesta a la operación de impregnación a vacío.

a. Determinación del pH, Brix, humedad, actividad de agua y densidad aparente.

b. Determinación del contenido de flavoniodes, fenoles totales y actividad antioxidante por los métodos de DPPH y ABTS.

c. Determinación del perfil de componentes fenólicos por HPLC

d. Determinación de las características microestructurales por CryoSEM.

e. Determinación de los parámetros de impregnación de rodajas de lulo con una disolución isotónica.

5. Preparación de zumo de lulo, aplicación de diferentes presiones de homogenización y caracterización de los zumos obtenidos.

a. Obtención de zumo de lulo y congelación del residuo para su uso posterior. Valoración del rendimiento. 
b. Homogeneización del zumo a 50, 100 y $150 \mathrm{MPa}$.

c. Caracterización fisicoquímica de los zumos obtenidos: pH, Brix, propiedades reológicas y ópticas, tamaño de partícula y densidad.

d. Caracterización funcional de los zumos obtenidos: fenoles totales, actividad antioxidante, flavonoides, perfil de compuestos fenólicos y contenido de espermidina

6. Preparación de zumo de lulo homogeneizado a diferentes presiones y a diferentes $\mathrm{pH}$ 's, inoculación con Lactobacillus reuteri CECT 925T, fermentación y caracterización.

a. Obtención de zumo de lulo y congelación del residuo para su uso posterior. Valoración del rendimiento.

b. Homogeneización del zumo a 100 y $150 \mathrm{MPa}$, y pasteurización a $72{ }^{\circ} \mathrm{C}$ C, 3 min.

c. Rectificación del pH de los zumos (pH 5,5 y 6), adición de levadura, inoculación con Lactobacillus reuteri CECT 925T e incubación (370C durante $24 \mathrm{~h}$ ).

d. Recuento de células viables de Lactobacillus reuteri CECT 925T.

e. Caracterización fisicoquímica de los zumos fermentados: pH, Brix, pulpa suspendida y turbidez, propiedades ópticas, tamaño de partícula y densidad.

f. Caracterización funcional de los zumos obtenidos: flavoniodes, fenoles totales, y actividad antioxidante por los métodos DPPH y ABTS.

7. Digestión gastrointestinal in vitro de los zumos fermentados.

a. Recuento de células viables de Lactobacillus reuteri CECT 925T al inicio y fin de las etapas gástrica e intestinal.

b. Determinación del contenido en flavoniodes, fenoles totales, y actividad antioxidante del fluido resultante tras la digestión 
gastrointestinal in vitro de los zumos fermentados y después de la digestión in vitro.

8. Caracterización fisicoquímica y funcional del bagazo resultante del proceso de obtención de zumo de lulo.

9. Secado por aire caliente o liofilización y triturado del bagazo resultante del proceso de obtención de zumo de lulo. Caracterización de los polvos finales obtenidos.

a. Secado por aire caliente a 60 y $70{ }^{\circ} \mathrm{C}$ y liofilizado hasta obtener una actividad de agua inferior a 0,3. Obtención de las curvas de secado por aire caliente a 60 y $70{ }^{\circ} \mathrm{C}$.

b. Triturado a dos velocidades distintas de los tres bagazos deshidratados con el fin de obtener un polvo de lulo de dos granulometrías diferentes.

c. Caracterización fisicoquímica de los polvos obtenidos: humedad, actividad de agua, sólidos solubles y color.

d. Caracterización funcional de los polvos obtenidos: fenoles totales, actividad antioxidante, flavonoides y contenido en carotenoides.

e. Obtención de las isotermas de adsorción y de las propiedades de interacción con el agua y con el aceite: solubilidad, higroscopicidad, humectabilidad, capacidad de hinchamiento, capacidad de atrapar agua, la capacidad de retener agua, capacidad emulsionante y capacidad de retención de aceite. 


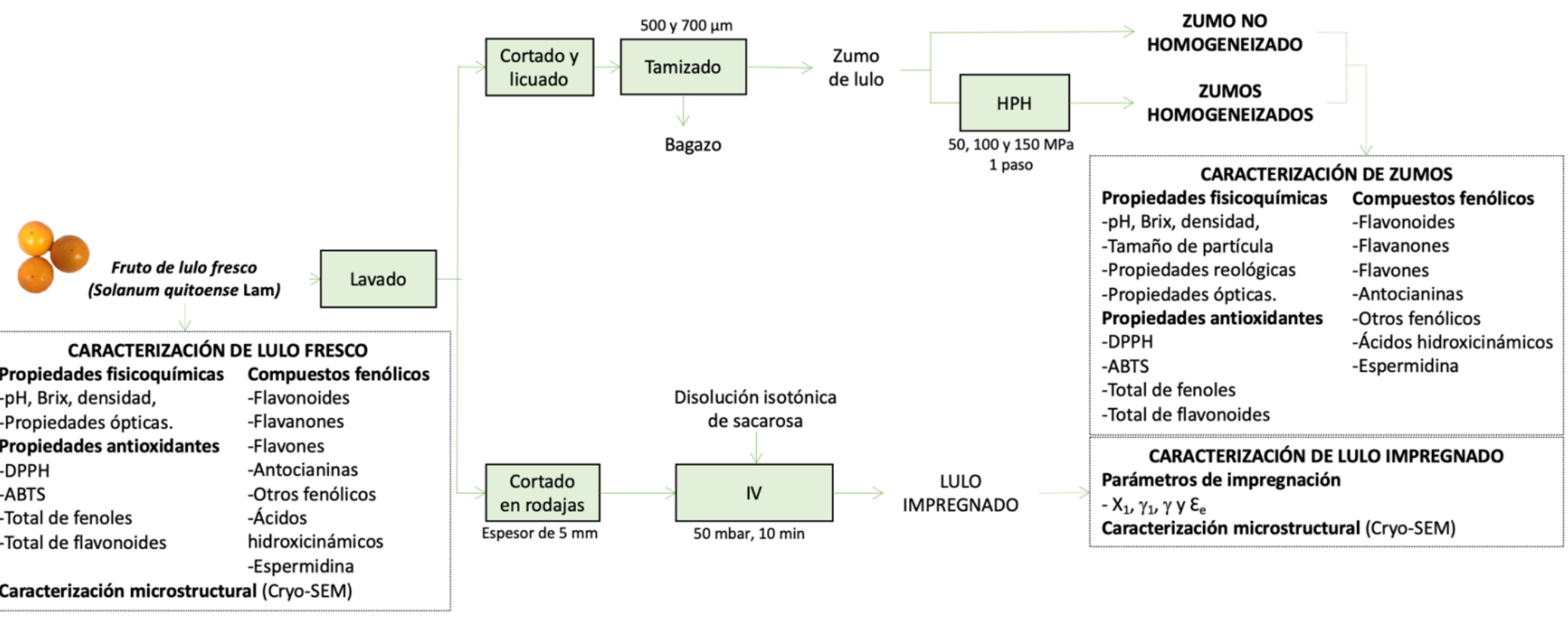

Figura 2.1. Diagrama de flujo seguido en la ejecución de los puntos 4 y 5 del plan de trabajo dirigidos a la consecución de los objetivos específicos 1.4 y 1.5 . 


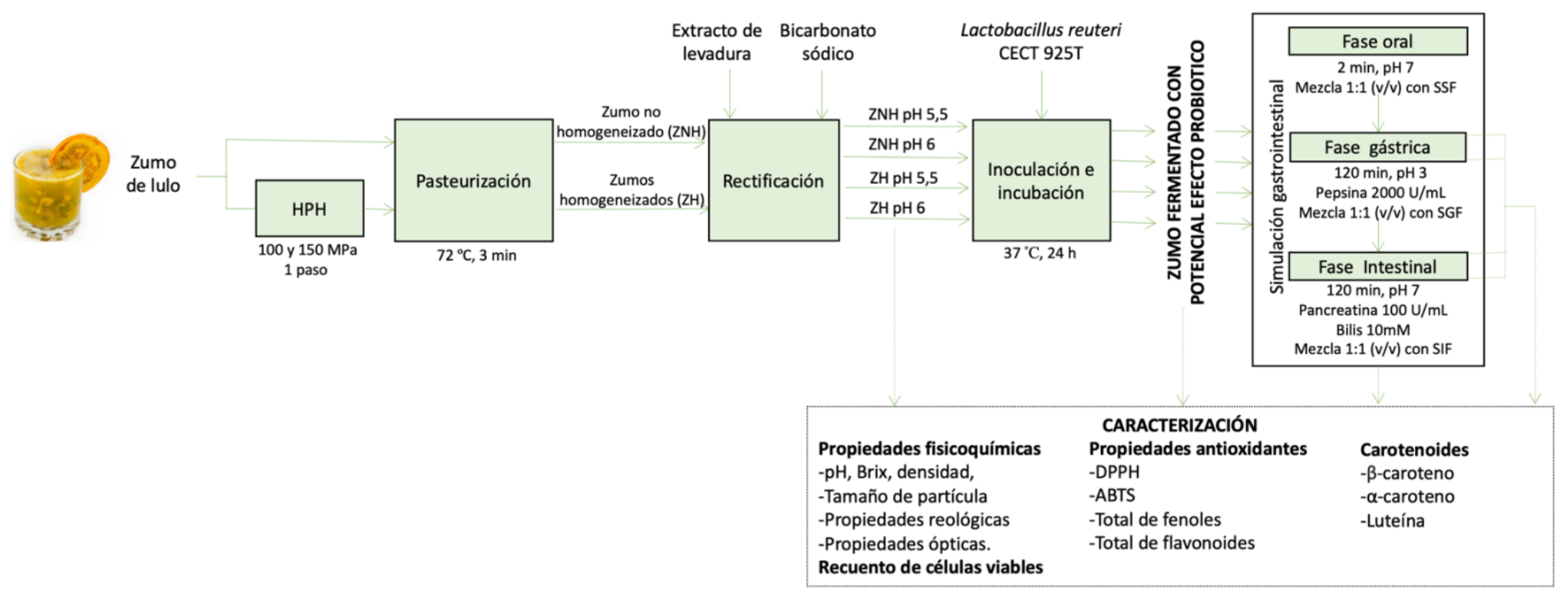

Figura 2.2. Diagrama de flujo seguido en la ejecución de los puntos 6 y 7 del plan de trabajo dirigidos a la consecución de los objetivos específicos $1.6,1.7$ y 1.8 . 


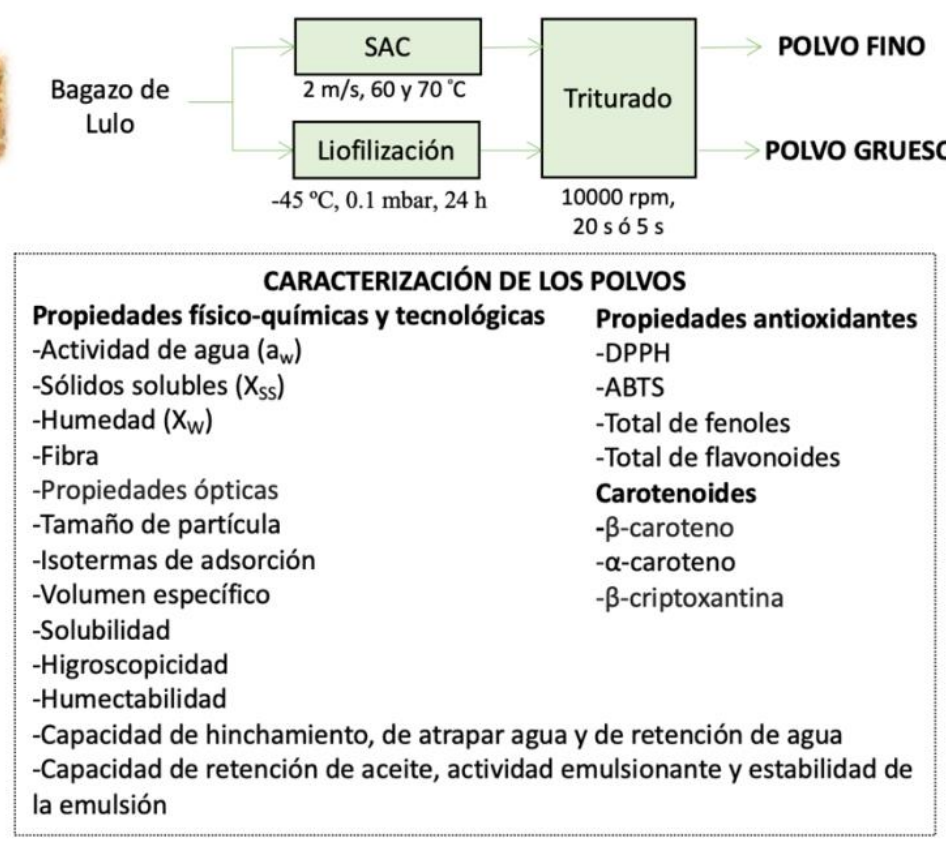

Figura 2.3. Diagrama de flujo seguido en la ejecución de los puntos 8 y 9 del plan de trabajo dirigidos a la consecución de los objetivos específicos $1.9,1.10$ y 1.11 . 
Resultados y discusión 
3. RESULTADOS Y DISCUSIÓN 
Resultados y discusión 
3.1. Estudio nutricional de la población infantil en la región del Chocó 
Resultados y discusión 
En este capitulo se presentan los resultados del estudio nutricional realizado sobre el colectivo de niños con edad comprendida entre 2 y 5 años en el departamento del Chocó, concretamente en la ciudad de Quibdó (Colombia). El estudio se realizó en colaboración con el Grupo de Valoración y Aprovechamiento de la Biodiversidad de la Universidad Tecnológica del Chocó, y la Congregación Cristiana Hermanas de Caridad. Los resultados obtenidos se han utilizado como antecedentes y justificación de un proyecto de cooperación que el grupo de investigación en Alimentos Funcionales del Instituto de Ingeniería de Alimentos para el Desarrollo ha solicitado a la Universitat Politècnica de València en el contexto de la convocatoria ADSIDEO 2021. El objetivo es transferir los resultados de la presente tesis doctoral, llevando a cabo acciones de educación-concienciación y desarrollo de productos a partir de recursos autóctonos, con la finalidad de mejorar la situación de desnutrición infantil aprovechando la enorme biodiversidad de la región.

Como ya se ha comentado en el apartado de introducción, la desnutrición infantil es un grave problema que afecta en la actualidad a un gran número de países en vías de desarrollo. En Colombia, en el periodo 2005-2017 se produjeron casi 400 muertes anuales por desnutrición en niños menores de 5 años, y los datos no han mejorado desde entonces. El departamento del Chocó y en especial sus principales zonas urbanas, están entre las regiones más afectadas. En este contexto, el gobierno colombiano, a través de sus programas orientados al bienestar de la infancia, promueve acciones para garantizar una apropiada nutrición en las etapas infantiles. En el caso del departamento del Chocó, se están llevando a cabo programas sociales como la Nutrichampa y a Coccina MIA, en los que se enmarca el estudio nutricional que se presenta en este capítulo.

El estudio nutricional se realizó en base a los resultados de una encuesta sobre hábitos alimenticios, parámetros antropométricos y situación socioeconómica de niños en edades comprendidas entre 2 y 5 años. La recogida de información se realizó en forma de encuesta, sobre un colectivo de 25 familias de la ciudad de Quibdó (Chocó) tras llevar a cabo sesiones informativas. En este capítulo se presentan únicamente los resultados correspondientes a los hábitos alimenticios. Los datos 
socioeconómicos y antropométricos no han podido presentarse por formar parte de otros estudios.

El tratamiento de los datos permitió la valoración del ajuste de la ingesta a los patrones nutricionales recomendados para la población colombiana de entre 2 y 5 años. Se identificaron los grupos de alimentos más consumidos, las deficiencias nutritivas más relevantes y las principales causas de estas.

Los datos permitieron evidenciar que, el $64 \%$ de las familias consume al menos 3 comidas al día, y el $36 \%$ no consume ningún alimento en la cena. Aunque las diferentes variedades de plátano, ricas en carbohidratos, son los alimentos más consumidos, la escasa ingesta diaria hace que el aporte energético pueda calificarse como medio-bajo; aunque existe un pequeño aporte de grasa, se trata, en prácticamente todos los casos, de grasas saturadas. En general, las deficiencias en los principales macronutrientes no son alarmantes, pero sí que lo es el aporte de fibra y de micronutrientes como las vitaminas $\mathrm{A}$ y $\mathrm{C}$ y minerales como el calcio. Esta situación esta provocada, principalmente, por la ausencia total de la leche fresca y el escaso consumo de frutas y verduras; el lulo es prácticamente la única fruta consumida y solo el $84 \%$ de las familias es capaz de proporcionarla en alguna comida (el $68 \%$ solo lo hace una vez al día).

Para mejorar estos aspectos, se propone:

- La puesta en marcha de programas educativos y de concienciación dirigidos a los padres jóvenes. Los programas deberán incluir aspectos relativos a la nutrición de la población infantil y también aspectos básicos de aprovechamiento, preparación y conservación de alimentos vegetales propios de la región.

- El diseño de nuevos alimentos más nutritivos y/o enriquecidos en fibra, minerales y/o vitaminas a partir de aquellos que más se consumen y que tienen una disponibilidad alta para la población más desfavorecida. El desarrollo de papillas enriquecidas en calcio, fibra y vitaminas a partir de las diferentes variedades de plátano y de zumos 
de lulo ricos en fibra y componentes bioactivos se presentan como estrategias prometedoras.

\subsubsection{Introducción}

De acuerdo con las condiciones socioeconómicas de los diferentes países en vía de desarrollo, la población infantil constituye uno de los sectores más castigados a nivel nutricional. Una dieta inadecuada, con importantes deficiencias de proteínas y micronutrientes, a edades tempranas afecta el crecimiento e impide un desarrollo físico y cognitivo normal. En el caso de Colombia, según la Encuesta Nacional de la Situación Nutricional (ENSIN), publicada por el Instituto Colombiano de Bienestar Familiar (2015) [1], las regiones con mayor prevalencia de deficiencia alimentaria en el grupo de edad de 2 a 5 años son: La región atlántica con un $58,7 \%$ y la región del pacífico con un $47,3 \%$.

En esta última región se encuentra ubicado el departamento del Chocó, con los mayores índices de prevalencia en malnutrición en niños menores de 5 años a nivel nacional. Según la Encuesta Nacional de Situación Nutricional (2015) y la Encuesta Nacional de Situación de Salud en Colombia (2019) ambas direccionadas y publicadas por el Ministerio de Salud y Protección Social (MINSALUD) [2], durante el periodo 20052017 se notificaron 4.956 muertes por desnutrición en niños menores de cinco años (392 muertes anuales). En 2017, la tasa de mortalidad más alta se presentó en los departamentos de Cesar, Chocó, la Guajira, Magdalena, Amazonas, Guainía, Vaupés y Vichada. Estos mismos departamentos presentaron los índices más altos de pobreza y desigualdad, y su población está integrada por el mayor número de grupos de riesgo (tribus indígenas, afrocolombianas y de bajos ingresos), sumando la población desplazada de la zona rural a la zona urbana.

En la actualidad, los gobiernos, a través de sus programas orientados al bienestar de la infancia, promueven acciones para garantizar una apropiada nutrición en las etapas infantiles; Colombia a través del programa de infancia y adolescencia del Ministerio de Protección Social, los programas del Instituto de Bienestar Familiar y los programas del Departamento para la Prosperidad Social atiende las necesidades alimentarias de este colectivo. 
En el caso del departamento del Chocó, programas sociales como la Nutrichampa y a Coccina MIA, suponen un esfuerzo en el área de la Seguridad Alimentaria y la Nutrición. Se trata de acciones que se realizan de manera puntual sin que estén directamente orientadas al fomento de prácticas de alimentación saludable y sostenible. Son acciones dirigidas a mitigar los efectos de las carencias nutricionales de las que no existen registros estadísticos que permitan conocer la situación real de la malnutrición en sus diferentes grados en niños menores de 5 años. En consecuencia, las acciones resultan insuficientes para disminuir los efectos de la falta de asistencia en la promoción y apropiación de una cultura de alimentación sana, balanceada y de calidad para el adecuado desarrollo de la niñez [3].

Teniendo en cuenta los planteamientos anteriores, y siendo evidentes las deficiencias nutricionales por parte del colectivo infantil en el departamento del Chocó, en el contexto de la presente tesis doctoral y en colaboración con la Congregación Cristiana Hermanas de Caridad, se realizó una encuesta para evaluar los hábitos alimenticios, estado nutricional y situación socioeconómica de niños en edades comprendidas entre 2 y 5 años. El tratamiento de los datos permitió hacer una valoración del ajuste de la ingesta a los patrones nutricionales recomendados para la población colombiana de entre 2 y 5 años, en el departamento del Chocó. La información obtenida servirá de base para el diseño de nuevos alimentos a partir de los recursos autóctonos y la propuesta de programas educativos dirigidos a conseguir una mejor nutrición de la población infantil en los colectivos más desfavorecidos.

\subsubsection{Métodos}

\section{Descripción del área y de la población objeto de estudio}

El departamento del Chocó es uno de los treinta y dos departamentos de Colombia. Está localizado en el noroeste del país, al costado oriental del océano Pacífico. Comprende las selvas del Darién y las cuentas de los ríos Atrato y San Juan. Su capital es Quibdó, área de intervención del proyecto, habitado por 129.273 personas aproximadamente, de las cuales, el 95,3\% corresponde a población afrocolombiana y solo el $2,3 \%$ mestizos o blancos. 
La población objeto de la investigación corresponde a 25 familias de escasos recursos (SISBEN nivel 1). En Colombia, el nivel socioeconómico de la población se determina utilizando la clasificación SISBEN, donde el nivel 1 corresponde a un nivel socioeconómico bajo y el 6 a un nivel socioeconómico más alto. La selección de la población se basó en los siguientes criterios: Desplazamiento por conflicto armado, procedentes de territorios rurales del departamento (Bojayá, Villa Claret, Tadó, Apartadó, Munguidó e Istmina), familias de nivel bajo de ingresos económicos cuyos hijos tuvieran entre 2 y 5 años, y con niveles de malnutrición diagnosticados. La información fue suministrada por la sanidad pública de Quibdó. Concretamente, se seleccionaron aquellos niños vinculados al Programa de Recuperación Nutricional - Asociación Humanitaria Niños del Chocó, a cargo de la Congregación Cristiana Hermanas de Caridad. Se realizaron visitas domiciliarias en las que se revisaron algunos parámetros antropométricos (no incluidos en este estudio), la situación socioeconómica del núcleo familiar y la disponibilidad de la familia a participar del programa.

\section{Sensibilización y obtención de la información}

Se llevaron a cabo jornadas de sensibilización en las instalaciones del programa de recuperación nutricional, dirigidas a las familias beneficiarias. El objetivo de las jornadas fue dar a conocer buenas prácticas de alimentación y la importancia de una dieta con un aporte de nutrientes adecuado para el crecimiento y desarrollo óptimo de la población infantil.

Para la obtención de la información relativa a los patrones dietéticos de consumo, se elaboró un cuestionario de preguntas semiabiertas. El cuestionario incluía preguntas relacionadas con el nivel educativo, el nivel socioeconómico y los hábitos de consumo (Figura 3.1), e iba dirigido a madres con hijos de edad comprendida entre 2 y 5 años. En la preparación del cuestionario se tuvo en cuenta que, generalmente, los alimentos que integran la canasta familiar en la región son productos autóctonos de uso tradicional adquiridos en las tiendas de barrio cercanas al lugar de residencia. Si bien esto limita el consumo de alimentos variados, 
cabe resaltar que favorece el consumo de productos frescos ya que algunos son cultivados en pequeñas azoteas o en el patio de la casa.
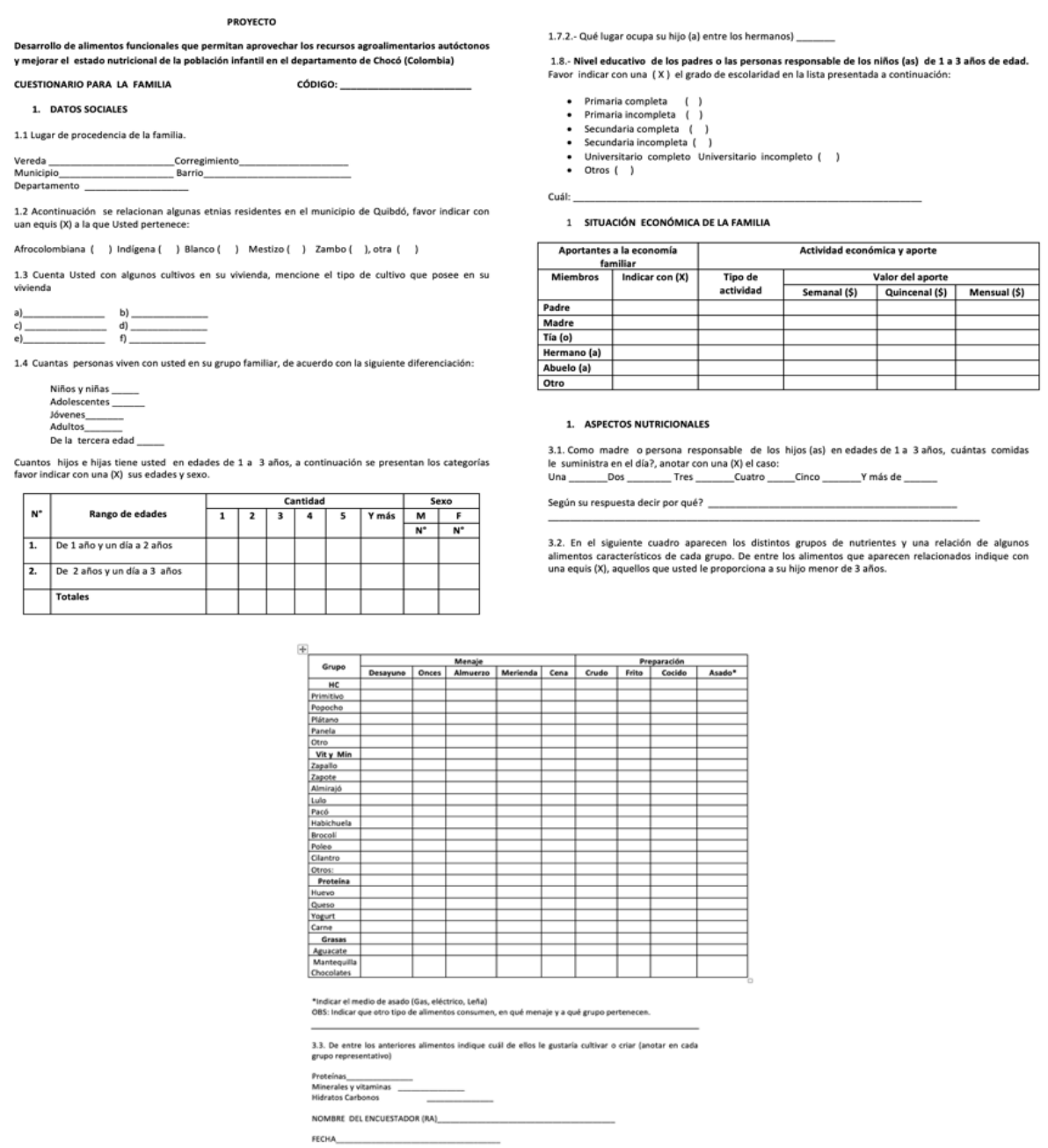

Figura 3.1. Documento proporcionado a las familias para la valoración nutricional 


\section{Tratamiento de los resultados de la encuesta}

El análisis de los datos de consumo se realizó con la finalidad de obtener información relativa a las siguientes cuestiones:

1. Número de comidas al día. Casos de "no consumo".

2. Alimentos más consumidos y su aporte nutricional.

3. Valoración nutricional de la ingesta. Se realizó teniendo en cuenta las "Guías Alimentarias Basadas en Alimentos para la población colombiana mayor de 2 años" publicadas por el Gobierno de Colombia (Comité Técnico Nacional de Guías Alimentarias - CTNGA) como resultado del Convenio №1258/13 suscrito entre el Instituto Colombiano de Bienestar familiar - ICBF y la Organización de las Naciones Unidas para la Alimentación y la Agricultura - FAO (https://www.icbf.gov.co/nutricion/guias-alimentarias-mayores-2-

anos). Se tuvieron en cuenta las listas de intercambio estandarizado de alimentos elaboradas por la Universidad de Antioquía. En estas listas se incluyen alimentos equivalentes con su peso y porciones 0 medidas caseras correspondientes a los diferentes grupos 0 subgrupos, y también el aporte nutricional promedio del intercambio. Los grupos considerados fueron:

Grupo I. Cereales, raíces, tubérculos y plátanos.

Subgrupo I. Cereales

Subgrupo II. Raíces

Subgrupo III. Tubérculos

Subgrupo IV. Plátanos

Grupo II. Frutas y verduras.

Subgrupo I. Frutas

Subgrupo II. Verduras

Grupo III. Leche y productos lácteos.

Subgrupo I-A. Leche entera

Subgrupo II-A. Productos lácteos grasa entera

Subgrupo I-B. Leche con reducción de grasa

Subgrupo II-B. Productos lácteos con reducción de grasa 
Grupo IV. Carnes, huevos, leguminosas secas, frutos secos y semillas.

Subgrupo I-A. Carnes magras crudas

Subgrupo I-B. Productos altos en grasas saturadas y colesterol

Subgrupo II. Huevos

Subgrupo III. Leguminosas cocidas y mezclas vegetales cocidas

Subgrupo IV. Nueces y semillas secas

Grupo V. Grasas

Subgrupo I. Grasas poliinsaturadas

Subgrupo II. Grasas monoinsaturadas

Subgrupo III. Grasas saturadas

Grupo VI. Azúcares

Subgrupo I. Azúcares simples

Subgrupo II. Dulces y postres

4. Adecuación de la ingesta a los patrones alimentarios recomendados para la población colombiana por grupo de edad. Se tuvieron en cuenta los cálculos del patrón alimentario para cada grupo de edad, considerando los intercambios necesarios para cubrir las metas nutricionales de cada grupo y asegurar una dieta completa, equilibrada, suficiente y adecuada, realizados por el equipo académico CTNGA, ICBF y FAO, con base a las listas de intercambio de alimentos de la Universidad de Antioquía.

5. Ajuste de la ingesta a las recomendaciones dietéticas por grupo de edad. Se tuvieron en cuenta las recomendaciones publicadas por la FAO.

\subsubsection{Resultados}

En primer lugar, es importante señalar que, en la ejecución de esta actividad se presentaron bastantes inconvenientes derivados de la falta de confianza de las madres en proporcionar información relativa a la ingesta de los menores. 
Finalmente, se obtuvieron 24 encuestas que, en términos generales, pusieron de manifiesto que las familias están compuestas por parejas jóvenes con 4 o 5 hijos pequeños, con un alto crecimiento de madres cabeza de hogar. Cerca del $60 \%$ de la población adulta se dedica a las ventas ambulantes, la celaduría, los oficios domésticos y otras actividades que no generan niveles de ingresos dignos. El $87 \%$ de los padres cuenta con estudios básicos y el 13\% no realizó ningún tipo de estudios. En cuanto a las madres, el $80 \%$ de estas cuentan con estudios básicos y un $20 \%$ no realizó ningún tipo de estudios.

En relación con el número de comidas al día, los resultados obtenidos muestran que más de la mitad de las familias (64\%) pueden consumir al menos 3 comidas al día, si bien el 36\% no consume ningún alimento en la cena. Además, coincide que son estas familias las que tienen un aporte energético medio-bajo en el desayuno y el almuerzo.

La dieta está integrada por los siguientes alimentos: plátano, popocho, primitivo y panela del grupo I; habichuela, zapallo, cilantro y lulo del grupo II; queso y yogur enteros del grupo III; huevo y carnes de pollo, res y cerdo del grupo IV; como fuente de grasas más frecuentemente consumida se incluyen los chocolates y la mantequilla teniendo el aguacate una presencia minoritaria. Cabe resaltar la ausencia de leche fresca pese a tratarse de la ingesta de niños de entre 2 y 5 años. No obstante, los alimentos más consumidos pertenecen a todos y cada uno de los grupos de alimentos, sirviendo de fuente de carbohidratos, proteínas, grasas, vitaminas y minerales.

En la figura 3.2 se muestran los porcentajes de presencia de alimentos de los diferentes grupos en las comidas. Puede observarse que las frutas, las verduras y los productos lácteos son los que menos presencia tienen en las diferentes comidas del día: El no consumo de lácteos se manifiesta en el $36 \%$ de los casos y en el $16 \%$ el no consumo de frutas y verduras. Además, resulta bastante frecuente que el consumo de frutas y verduras se realice en una única comida con la consiguiente deficiencia asociada al aporte de vitaminas, minerales y fibra. 


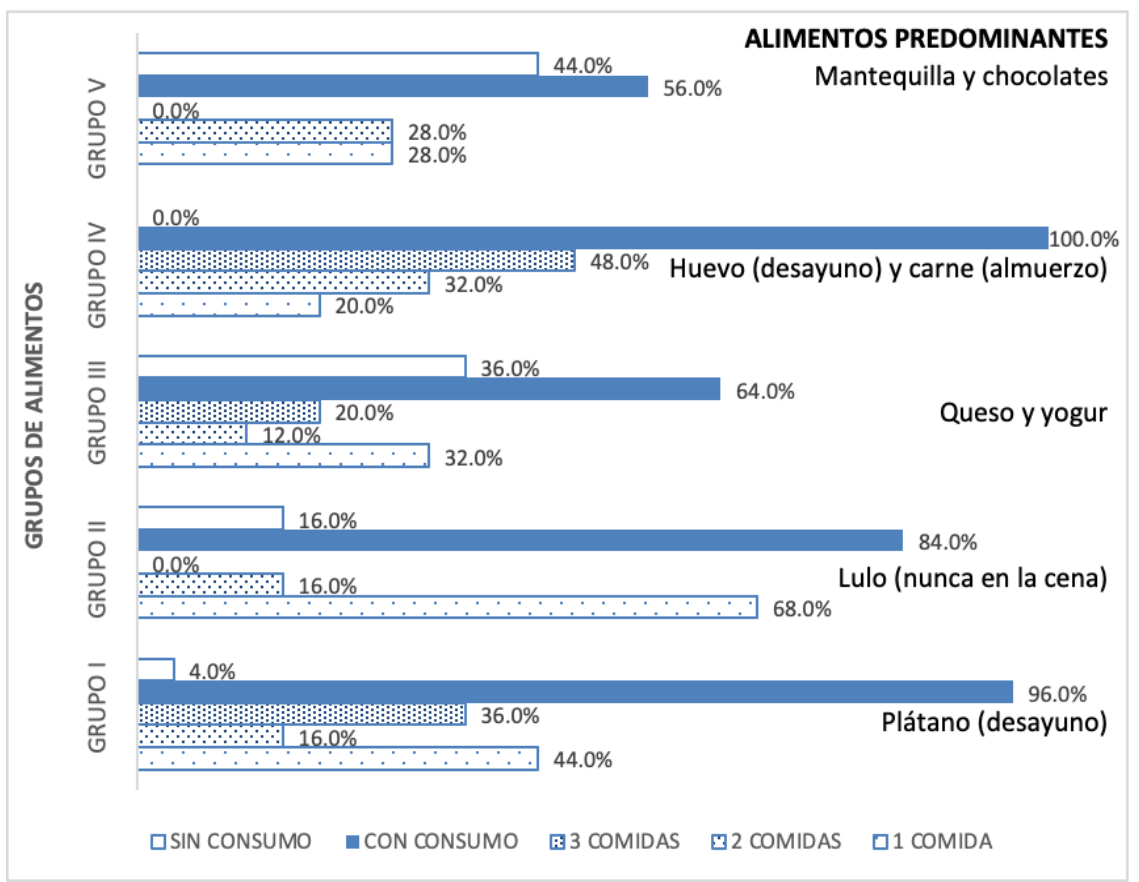

Figura 3.2. Distribución de los alimentos en las comidas y alimentos más consumidos.

Para poder valorar la adecuación de la ingesta a los patrones alimentarios recomendados, se definió un índice de adecuación al patrón alimentario recomendado para la población colombiana entre 2 y 5 años, como el cociente entre la ingesta de una determinada cantidad diaria de un macro o micronutriente determinado y la cantidad recomendada para ese nutriente según los cálculos realizados por el equipo académico CTNGA, ICBF y FAO, con base a las listas de intercambio de alimentos de la Universidad de Antioquía.

En la figura 3.3 se han representado los percentiles muestrales o valores por debajo de los cuales se encuentra un porcentaje específico de los datos, para el índice de adecuación de la energía, de los 4 macronutrientes fundamentales (proteína, grasa, carbohidratos y fibra), los 3 minerales más importantes para el crecimiento (calcio, hierro y zinc) y las vitaminas A y C. En la tabla 3.1 se establece la relación de transformación del índice a las recomendaciones internacionales de ingesta realizadas por la OMS para el grupo de edad entre 2 y 5 años. 


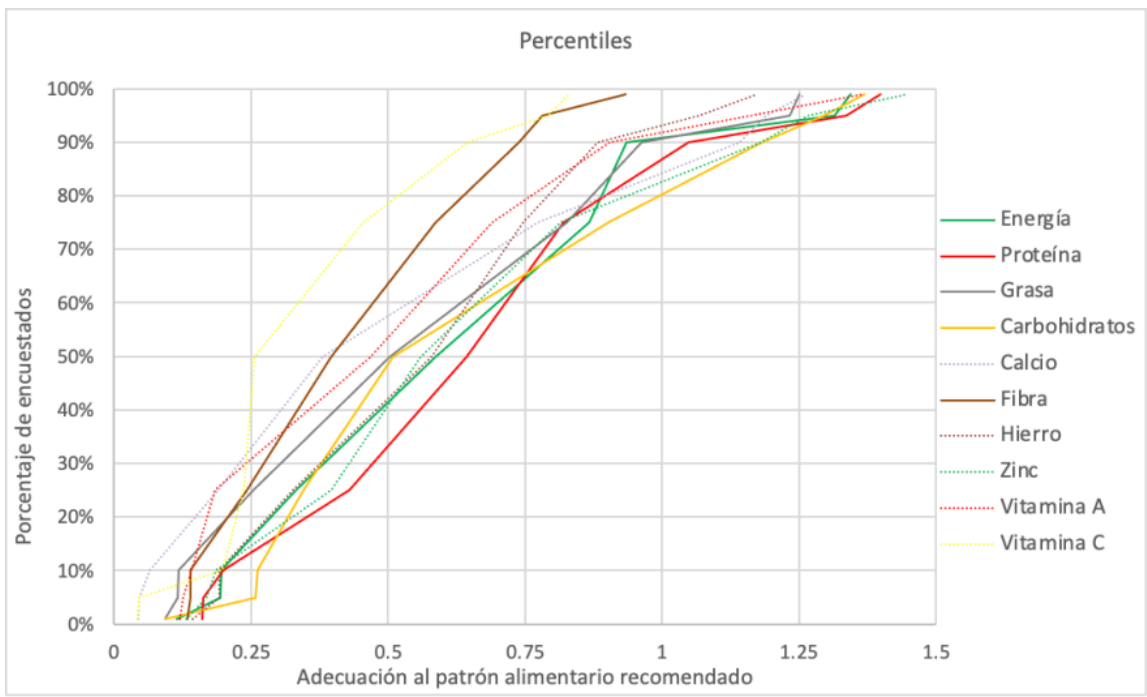

Figura 3.3. Porcentaje de encuestados con un determinado índice de adecuación al patrón alimentario recomendado diario.

Considerando que, un valor de 1 , en cuanto a niveles de adecuación de un patrón alimentario, indica que la ingesta de nutrientes se ajusta a la recomendada por el gobierno colombiano de acuerdo a su canasta básica de alimentos y a la accesibilidad de los grupos poblacionales menos favorecidos, es posible ver que del total de familias incluidas en el estudio, como máximo un $20 \%$ muestran una adecuación al patrón alimentario recomendado en cuanto a la ingesta de energía y macronutrientes, a excepción de la ingesta de fibra. Tanto para la fibra como para la vitamina C, el $100 \%$ de las familias no alcanza el nivel 1 de adecuación al patrón alimenticio. Esto se debe a que las frutas y verduras son el grupo de alimentos con menor ingesta, como se observa en la figura 3.2. Solamente el lulo es consumido por más de la mitad de las familias, pero exclusivamente en una comida al día.

Existen pocos estudios sobre los efectos de la ingesta de fibra en el crecimiento y desarrollo de los niños, pero algunas investigaciones mencionan que una ingesta baja de fibra conlleva a problemas de estreñimiento y apendicitis infantil [4]. Larrosa et al. [4] analizaron la relación entre la ingesta de fibra durante la infancia y los marcadores de salud cardiovascular en niños entre 3-8 años, y observaron que una ingesta insuficiente de fibra desde la infancia está asociada a una baja tolerancia a la glucosa. En cuanto a la vitamina $A$, se ha demostrado que los niveles 
bajos de vitamina $A$ se asocian con enfermedades respiratorias y diarreicas, retardo en el crecimiento, sistema inmune mermado, xerofalmia y enfermedades cognitivas [5], provocando incluso mortalidad por enfermedades gastrointestinales y respiratorias [6]. Según la estrategia nacional para la prevención y control de las deficiencias de micronutrientes en Colombia (2014-2021) y la situación actual de los micronutrientes en Latinoamérica y el Caribe (2018), Colombia es uno de los países con mayor riesgo deficiencia de vitamina $A$ en los niños [5]. Martín-Torres, Meneses-Echavéz y Ramírez-Vélez [5] estudiaron la prevalencia de los factores demográficos asociados con la deficiencia de vitamina $A$ en niños colombianos de entre 1 y 5 años. Encontraron que esta deficiencia es mayor en las poblaciones pertenecientes a grupos étnicos de ascendencia africana, los que viven en las regiones de Orinoquia y Amazonia. Del mismo modo, Kundun Rai y Shukla [7], estudiaron la deficiencia de vitamina $A$ en niños con edades comprendidas entre 1 y 5 años de varios extractos socioeconómicos y demográficos en la India, encontrando que una ingesta inadecuada de vitamina $A$ provoca retraso en el crecimiento, y afecta el sistema inmunológico del infante. En el mismo estudio, se vio la importancia de algunos factores sociodemográficos en el estado nutricional de los niños; la deficiencia de la vitamina A disminuyó al aumentar los años de educación de la madre. Botero-Meses et al. [8] evaluaron el estado nutricional, habilidades de aprendizaje y el desarrollo cognitivo de los niños en una población desfavorecida de niños entre 5 y 11 años de educación primaria. El estudio reveló que la población con un índice alto de prevalencia en malnutrición presentaba también deficiencias en las habilidades de aprendizaje.

También, se ha demostrado en diferentes estudios que la deficiencia de vitamina $\mathrm{C}$ se relaciona con el asma y una función pulmonar disminuida en la niñez [9]; otros estudios manifiestan que la deficiencia de vitamina $\mathrm{C}$ afecta negativamente al crecimiento físico y mental, y también puede afectar sus defensas inmunológicas [10]. 
Tabla 3.1. Relación entre el patrón alimentario recomendado y las recomendaciones internacionales de ingesta de nutrientes para la población colombiana de 2 a 5 años de edad.

\begin{tabular}{cc} 
& Patrón alimentario recomendado (Gobierno de Colombia) \\
\cline { 2 - 2 } ENERGÍA & Recomendaciones internacionales (OMS) \\
PROTEÍNA & 0.97 \\
GRASAS & 1.04 \\
CARBOHIDRATOS & 1.04 \\
FIBRA & 1.03 \\
Ca & 0.97 \\
Fe & 1.13 \\
Zn & 0.80 \\
Vit A & 1.35 \\
vit C & 2.99
\end{tabular}

Los resultados muestran que los hidratos de carbonos son los macronutrientes más consumidos, y aún así en el $80 \%$ de los encuestados el índice de adecuación es inferior a 1.

Adicionalmente, la distribución de alimentos en cada una de las comidas dista muyo de ser equilibrada y saludable. En la figura 3.4 se muestras los datos de distribución porcentual de los alimentos consumidos en el desayuno. Los datos revelaron que los hidratos de carbono procedentes de la combinación plátano y panela; y popocho, primitivo, plátano y panela, fueron los más consumidos con porcentajes del $34 \%$ y $13 \%$ para cada uno de los grupos mencionados. Un porcentaje del $9 \%$, consumió solo popocho y un $8 \%$ solo plátano o el primitivo y la panela $8 \%$. En cuanto a las frutas y verduras son el $84 \%$ los que no presentan ningún consumo en el desayuno. Las proteínas más consumidas en el desayuno son el huevo con un $34 \%$ y la combinación de huevo-queso con un $25 \%$. El no consumo representa el $17 \%$. Las grasas aportadas por la combinación de mantequilla y chocolate son las únicas presentes, lo que representa un $50 \%$ y de no consumo un $50 \%$. 


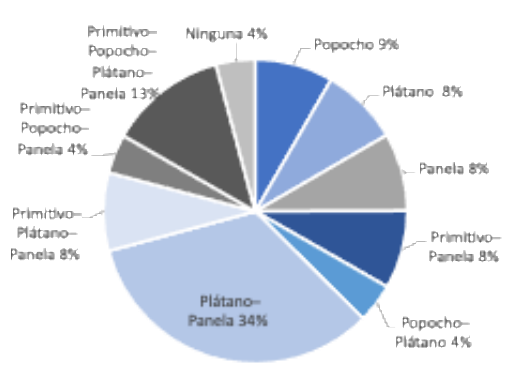

(a)

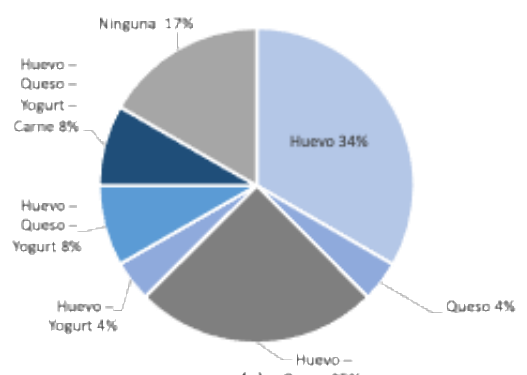

(c) queso $25 \%$

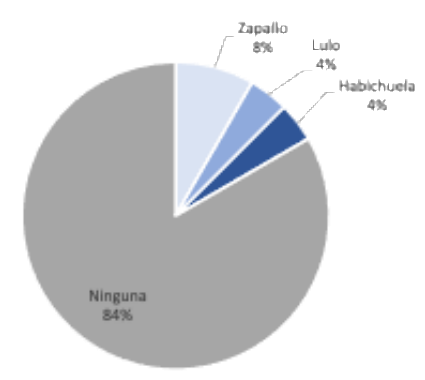

(b)

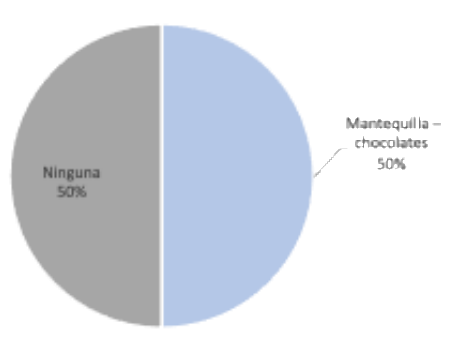

(d)

Figura 3.4. Distribución porcentual de ingesta de alimentos por grupos alimenticios en el desayuno. a: hidratos de carbono, b: vitaminas y minerales, c: proteínas y d: grasas.

Con respecto al almuerzo, la figura 3.5 muestra una tendencia similar en los hidratos de carbono, siendo el plátano el alimento más consumido con un $21 \%$, seguido por el popocho y la combinación popocho- panela con un 4\%. El no consumo presenta un porcentaje del 54 \%. El aporte de vitaminas y minerales está principalmente representado por el consumo de lulo que representa un $54 \%$. En un porcentaje menor se encuentran las combinaciones de habichuela-cilantro y lulo-habichuelapoleo-cilantro (9\%) y zapallo-lulo-habichuela-cilantro, zapallo-lulohabichuela-brócoli-cilantro, lulo-habichuela-cilandro y zapallo-lulohabichuela-brócoli-cilandro (todas con un $4 \%$ ). El no consumo supone un $8 \%$. En cuanto a la proteína en el almuerzo solo el $38 \%$ ingiere solo carne, seguido por un $21 \%$ que ingieren queso- carne. En este caso el no consumo supone solo un $8 \%$. Las grasas prácticamente están ausentes en esta comida (92\%). 


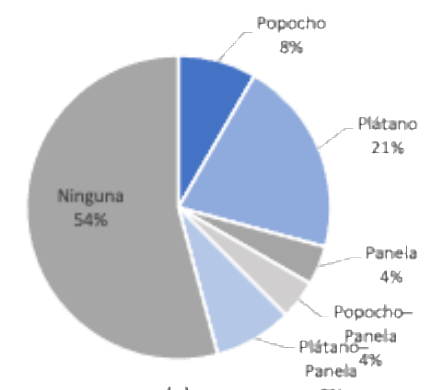

(a)

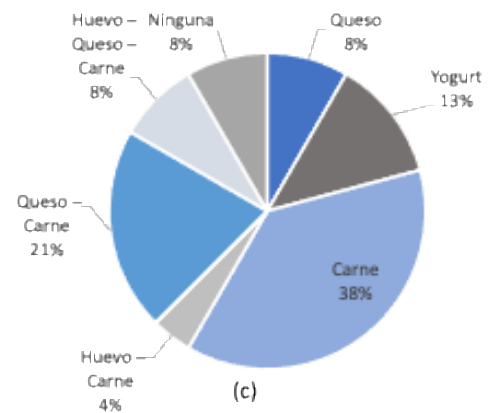

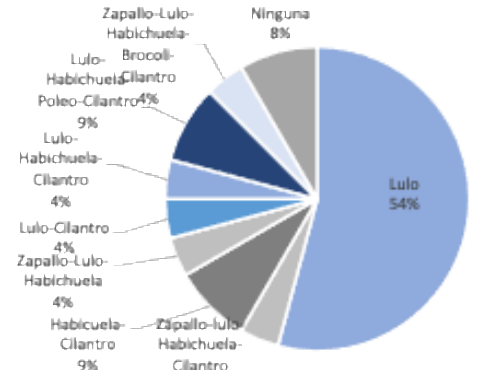

(b)

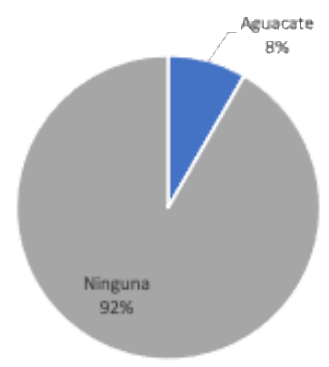

(d)

Figura 3.5. Distribución porcentual de ingesta de alimentos por grupos alimenticios en el almuerzo. a: hidratos de carbono, b: vitaminas y minerales, c: proteínas y d: grasas.

En la cena (Figura 3.6), el alimento más consumido es el primitivo con panela en un porcentaje del $12 \%$ y el no consumo representa un $48 \%$. La principal fuente de proteína es el huevo con una presencia del $29 \%$, seguido de la combinación queso y huevo con un $13 \%$. El no consumo representa el $46 \%$. El aporte de grasas con el consumo de mantequilla y chocolate supone el $29 \%$ y el no consumo representa el $71 \%$. 


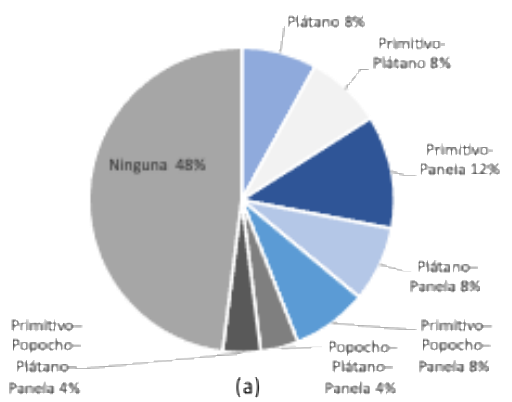

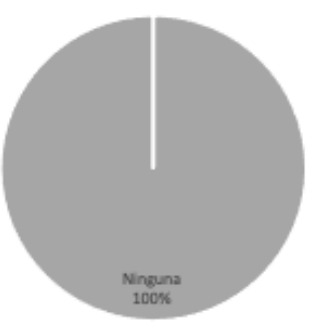

(b)

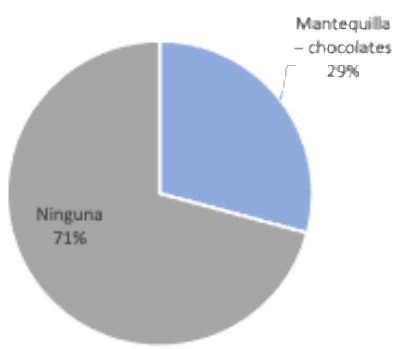

(d)

Figura 3.6. Distribución porcentual de ingesta de alimentos por grupos alimenticios en la cena. a: hidratos de carbono, b: vitaminas y minerales, c: proteínas y d: grasas.

En general los hábitos de consumo revelaron deficiencias en el consumo de vitaminas y minerales seguidos por el de proteínas y grasas, lo que resalta la generalización de una alimentación inadecuada.

Una dieta variada debe incluir de cuatro a cinco grupos de alimentos principales: frutas y verduras, cereales, alimentos con almidón, alimentos con proteínas y productos lácteos para un adecuado crecimiento normal. En relación con cada uno de los grupos alimenticios básicos, los resultados obtenidos muestran que la mayoría son básicamente fuente de hidratos de carbono, resaltando el bajo consumo de alimentos ricos en proteínas, vitaminas y minerales como la carne, la leche, las verduras y las frutas. Esta situación está claramente relacionada con el nivel de ingreso de las familias; un elevado porcentaje de ellas no pueden acceder a la oferta de productos en el mercado habitual. Los niños se alimentan con el mismo menú que sus padres, esto conduce a que no realicen una ingesta adecuada acorde con su etapa de crecimiento.

En general, nuestros hallazgos muestran la necesidad de reforzar las políticas públicas orientadas a promover hábitos de alimentación 
saludables en la infancia y a llevar a cabo programas de educación nutricional tanto para los niños como para sus padres. Estas acciones deben estar en la planificación del cronograma de los funcionarios de salud pública como extremadamente necesarias para mejorar la adecuación de la ingesta de micronutrientes y para disminuir la desnutrición en la población infantil. 


\subsubsection{Conclusiones del capitulo 3.1}

Muchos niños pertenecientes a la población infantil de entre 2 y 5 años de la región urbana de Quibdó en el departamento del Chocó (Colombia) realizan diariamente una ingesta inadecuada para su edad. Aunque las deficiencias en los principales macronutrientes no son alarmantes, sí que lo es el aporte de fibra y de micronutrientes como las vitaminas $\mathrm{A}$ y $\mathrm{C}$ y minerales como el calcio. Esta situación está provocada, principalmente, por la ausencia total de la leche fresca y el escaso consumo de frutas y verduras. La ingesta inadecuada entre los 2 y los 5 años tiene un impacto negativo en el desarrollo cognitivo, la salud y el bienestar a largo plazo, así como la salud de las generaciones siguientes. Se necesitan acciones que permitan mejorar la ingesta alimentaria adecuándola a las recomendaciones de macro y micronutrientes en el grupo de edad. En general, nuestros hallazgos muestran la necesidad de reforzar las políticas públicas orientadas a promover hábitos de alimentación saludables en la infancia y los programas de educación nutricional y formación tecnológica básica. Estas acciones deben estar en la planificación del cronograma de los funcionarios de salud pública. Además, el diseño de nuevos alimentos más nutritivos y/o enriquecidos en fibra, minerales y/o vitaminas a partir de aquellos que más se consumen y que tienen una disponibilidad alta para la población más desfavorecida puede ser una estrategia prometedora. 


\section{Bibliografía}

1. Instituto Colombiano de Bienestar Familiar, Profamilia, Instituto Nacional de Salud. Ministerio de Protección Social, Encuesta Nacional de Situación Nutricional en Colombia 2015.2 Available online: https://www.icbf.gov.co/bienestar/nutricion/encuesta-nacional-situacionnutricional (accessed on Aug 27, 2021).

2. Ministerio de Salud y Protección Social.Minsalud, Análisis de Situacion de Salud (ASIS). Colombia, 2019. Available online: https://www.minsalud.gov.co/salud/publica/epidemiologia/Paginas/analisis-desituacion-de-salud-.aspx (accessed on Jul, 29,2021)

3. Plan de Desarrollo. Alcaldia Municipal de Quibdo- Chocó 2016-2019; Available online: https://colectivoarquitectoslocales.files.wordpress.com/2016/05/pdversion-final.pdf (accessed on Jul, 29,2021)

4. Larrosa, S.; Luque, V.; Grote, V.; Closa-Monasterolo, R.; Ferré, N.; Koletzko, B.; Verduci, E.; Gruszfeld, D.; Xhonneux, A.; Escribano, J. Fibre Intake Is Associated with Cardiovascular Health in European Children. Nutr. 2021, Vol. 13, Page 12 2021, 13, 12

5. Martínez-Torres, J.; Meneses-Echavéz, J.F.; Ramírez-Vélez, R. Prevalence of demographic factors associated with vitamin A deficiency in Colombian children aged 12-59 months. Endocrinol. y Nutr. (English Ed. 2014, 61, 460-466

6. Thornton, K.A.; Mora-Plazas, M.; Marín, C.; Villamor, E. Vitamin A Deficiency Is Associated with Gastrointestinal and Respiratory Morbidity in School-Age Children. J. Nutr. 2014, 144, 496.

7. Kundu, S.; Rai, B.; Shukla, A. Prevalence and determinants of Vitamin A deficiency among children in India: Findings from a national cross-sectional survey. Clin. Epidemiol. Glob. Heal. 2021, 11, 100768.

8. Botero-Meneses, J.S.; Aguilera-Otalvaro, P.A.; Pradilla, I.; Talero-Gutiérrez, C.; Ruiz-Sternberg, Á.M.; Vélez-van-Meerbeke, A.; Pinzón-Rondón, A.M. Assessment of nutrition and learning skills in children aged 5-11 years old from two elementary schools in Chocó, Colombia. Heliyon 2020, 6, e03821.

9. Siripornpanich, S.; Chongviriyaphan, N.; Manuyakorn, W.; Matangkasombut, P. Allergy and Immunology Zinc and vitamin C deficiencies associate with poor pulmonary function in children with persistent asthma. Asian Pacific J. Allergy Immunol. 2020.

10. Maggini, S.; Wenzlaff, S.; Hornig, D. Essential role of vitamin c and zinc in child immunity and health. J. Int. Med. Res. 2010, 38, 386-414 
Resultados y discusión 
3.2. Posibilidades de desarrollo de alimentos funcionales a partir del fruto del lulo. Aplicación de tecnologías no térmicas e incorporación de probióticos 
Resultados y discusión 
Los resultados del capítulo 3.1 permitieron establecer la necesidad de mejorar la situación de desnutrición en la población infantil del departamento del Chocó, mediante el diseño y desarrollo de nuevos alimentos más nutritivos $\mathrm{y} / \mathrm{o}$ enriquecidos en fibra, minerales $\mathrm{y} / \mathrm{o}$ vitaminas a partir de aquellos que más se consumen y que tienen una disponibilidad alta para la población más desfavorecida. Concretamente, el desarrollo de zumo de lulo rico en fibra y componentes bioactivos se presentó como una estrategia prometedora.

También se expuso en la introducción, que la malnutrición en la población adulta ha aumentado en gran medida los problemas de sobrepeso y obesidad, provocando un incremento en la prevalencia de enfermedades no transmisibles como la hipertensión.

El presente capitulo se centra en:

1. Dilucidar cuáles son los componentes bioactivos y los microrganismos con efecto probióticos que pueden tener un efecto favorable en la prevención de las alteraciones asociadas a desordenes fisiológicos como la hipertensión y la obesidad.

El sobrepeso y la obesidad se definen como una acumulación anormal o excesiva de grasa que puede perjudicar la salud. Normalmente, un índice de masa corporal elevado (IMC $\geq 25-30$ ) se asocia a otras anomalías metabólicas, como la hipertensión, la hiperglucemia y/o la hipercolesterolemia. La presencia de al menos tres de estos factores fisiológicos, bioquímicos, clínicos y metabólicos que aumentan el riesgo de enfermedad cardiovascular, cáncer y diabetes de tipo 2 se conoce como síndrome metabólico. La Federación Internacional de Diabetes estima que una cuarta parte de la población adulta mundial padece este síndrome, con poca diferencia entre los países desarrollados y los que están en vías de desarrollo. Los principales factores que contribuyen a la aparición de estas alteraciones son: el aumento del consumo de alimentos hipercalóricos y la escasa actividad física. Dado que el síndrome metabólico puede presentarse de varias formas, según la combinación de los distintos componentes, es aparentemente difícil tratarlo farmacológicamente, siendo el cambio de estilo de vida el enfoque preventivo más eficaz. Sin embargo, el hecho de que un estado 
inflamatorio crónico acompañe al síndrome metabólico en cualquiera de sus formas sugiere que las terapias antiinflamatorias podrían resultar eficaces para la prevención y el tratamiento. En concreto, se documenta que una ingesta de compuestos con capacidad antioxidante o de microorganismos probióticos capaces de modular la microbiota intestinal puede tener importantes efectos favorables.

Se realizó un trabajo de prospección con la finalidad de identificar los compuestos bioactivos más relevantes con efecto probado contra algún trastorno asociado al síndrome metabólico. Centrándonos en los microorganismos probióticos y en los compuestos fitoquímicos, se recopilaron las evidencias obtenidas en estudios in vitro, in vivo o clínicos en los últimos 10 años. Por último, y en coherencia con los resultados obtenidos se propusieron nuevos alimentos funcionales elaborados a partir del fruto del lulo como potencialmente adecuados para la prevención y/o mejora del síndrome metabólico.

El trabajo de prospección ha sido publicado como capitulo de un libro de editorial internacional:

Betoret, N., Hinestroza- Córdoba, L.I., Segui, L., Barrera, C. (2019). Probiotics and other bioactive compounds with proven effect against obesity and hypertension. Food design opportunities from lulo fruit (Solanum quitoense). Chapter 4, IntechOpen.

DOI: 10.5772/intechopen.85482. https://www.intechopen.com/online first/probiotics-and- other-bioactive- compounds-with-proven-effectagainst-obesity-and-hypertension food. continuación.

Los principales resultados del trabajo se describen a

Los compuestos fitoquímicos han ganado popularidad en los últimos años debido a su efecto en la prevención y el tratamiento de la obesidad, el colesterol y la diabetes. Los mecanismos por los que los compuestos fitoquímicos contribuyen a mejorar los factores de riesgo del síndrome metabólico son diversos y dependen de su estructura química particular. Así, por ejemplo, las catequinas inducen principalmente la 
oxidación de las grasas y mejoran la función endotelial. Las cianidinas y las teaflavinas inhiben las enzimas implicadas en la síntesis de ácidos grasos y triglicéridos. Otros fitoquímicos, como el ácido gálico, la quercetina y la capsaicina, reducen la proliferación de preadipocitos mediante la inducción de la apoptosis celular, mientras que las proantocianidinas inducen la inhibición de la enzima convertidora de la angiotensina. Al tener una estructura química similar, las isoflavonas también pueden influir en la actividad de los estrógenos humanos. Aunque los estudios in vitro o en animales han proporcionado resultados positivos, los estudios clínicos en humanos aún no son concluyentes. Además, la mayoría de los estudios tanto in vitro como con animales, se han realizado con componentes sintéticos (sólo la espermidina se obtuvo directamente del fruto del lulo), mientras que los estudios in vivo con humanos se han realizado principalmente con extractos de los compuestos bioactivos.

En cuanto a las cepas probióticas empleadas en el tratamiento de diversas enfermedades inflamatorias, suelen pertenecer a los géneros Lactobacillus y Bifidobacterium, aunque Pediococcus pentosaceus LP28, Bacteroides uniformis CECT 7771 y Akkermansia muciniphila también han demostrado tener efectos contra la obesidad. En general, se trabaja con dosis superiores a $10^{8} \mathrm{UFC} /$ día por vía oral suministrados como polvos liofilizados que se disuelven en agua o que se ingieren directamente en forma de cápsulas. El principal mecanismo por el que los microrganismos probióticos ejercen un efecto beneficioso sobre el síndrome metabólico esta relacionado con el aumento de la diversidad bacteriana de la microflora intestinal. En los pacientes con sobrepeso/obesidad, Bacteroides, Parabacteroides, Ruminococcus, Campylobacter, Dialister, Porphyromonas, Staphylococcus y Anaerostipes son los géneros dominantes vinculados a una baja diversidad de especies; mientras que Faecalibacterium, Bifidobacterium, Lactobacillus, Butyrivibrio, Alistipes, Akkermansia, Coprococcus y Methanobrevibacter son predominantes en individuos delgados con una alta diversidad bacteriana. Aparentemente, la microbiota intestinal de los sujetos obesos es más eficiente para extraer energía de una dieta determinada que la de los individuos delgados, lo que conduce a un mayor almacenamiento de energía y adiposidad. Además, se sabe que la microflora intestinal beneficiosa produce ácidos grasos de 
cadena corta (por ejemplo, acetato, butirato y propionato) a partir de polisacáridos no digeribles, que pueden actuar como sustratos energéticos, así como reguladores de la saciedad y la ingesta de alimentos. Dado que la composición de la microflora intestinal se ve muy afectada por los patrones dietéticos, los estudios que evalúan el efecto de ciertos componentes alimentarios sobre el crecimiento de bacterias con efecto beneficioso, en particular Akkermansia muciniphila y Faecalibacterium prausnitzii, son de gran interés.

2. Determinar las posibilidades de utilizar tecnologías no térmicas como las altas presiones de homogeneización (HPH) para mejorar la calidad, funcionalidad y la sostenibilidad de los alimentos. Aunque se trata de tecnologías avanzadas, los costes de su aplicación no son elevados y podrían ser implementadas por pequeñas y medianas empresas de regiones en desarrollo para producir zumos de frutas tropicales altamente nutritivos y de elevado consumo.

La aplicación de altas presiones de homogeneización (HPH) en la industria alimentaria ha ido ampliando sus horizontes en los últimos años. Sus principales aplicaciones se centran en alimentos líquidos integrados por diferentes fases y derivan de su efecto sobre las partículas dispersas; tanto la estructura del líquido como la de los elementos que lo constituyen (partículas, moléculas, glóbulos, gotas, agregados, gránulos, etc.) sufren cambios al ser sometidos a esfuerzos cortantes y fenómenos de cavitación. Aunque sus orígenes se encuentran en la industria láctea, su aplicación en la industria de frutas es muy prometedora.

Se realizó un trabajo de revisión bibliográfica sobre las aplicaciones de las HPH en la industria alimentaria. La revisión se planteó con la finalidad de conocer como la necesidad de combinar seguridad, funcionalidad y sostenibilidad alimentaria ha condicionado la aplicación de este tratamiento en la última década. El trabajó se publicó en la revista Molecules (ISSN: 1420-3049; Current Impact Factor: 4.411; 5-year Impact Factor: 4.587; JCR category rank: Q2: Biochemistry \& Molecular Biology / Q2: Chemistry, Multidisciplinary).

Mesa, J., Hinestroza-Córdoba, L. I., Barrera, C., Seguí, L., Betoret, E., \& Betoret, N. (2020). High Homogenization Pressures to Improve Food 
Quality, Functionality and Sustainability. Molecules (Basel,
Switzerland), 25(14), 3305. https://doi.org/10.3390/molecules25143305

La revisión puso de manifiesto que las principales aplicaciones del tratamiento de HPH van dirigidas a: (i) Disminuir la carga microbiana e inactivar enzimas contribuyendo a la conservación sin o con tratamiento térmico reducido. Este efecto se consigue como consecuencia del efecto térmico que deriva del estrés mecánico al que es sometido el alimento líquido. (ii) Extraer y recuperar proteínas, fibras y componentes bioactivos de especial interés, aumentando su funcionalidad tecnológica (capacidad estabilizante, capacidad emulsionante...). La rotura de estructuras celulares y la modificación de estructuras macromoleculares producidas por los esfuerzos mecánicos e hidrodinámicos son el principal mecanismo por el que se favorecen los procesos de extracción. (iii) Aumentar la funcionalidad en términos de efecto sobre la salud (biodisponibilidad, bioaccesibilidad y efecto probiótico) de componentes bioactivos y probioticos. Este aumento de la funcionalidad se produce como consecuencia de facilitar la liberación de los componentes bioactivos, modificar las estructuras moleculares $\mathrm{y} / \mathrm{o}$ favorecer interacciones entre partículas. Además, las HPH pueden utilizarse en procesos de micro o nanoencapsulación.

3. Determinar el uso potencial de la impregnación a vacío y las HPH para obtener productos funcionales a partir del fruto del lulo. Será necesario conocer las características estructurales y las propiedades fisicoquímicas y funcionales del fruto del lulo y de su zumo y evaluar el efecto de las HPH sobre las mismas.

Los resultados obtenidos en los apartados anteriores justifican que el fruto del lulo, debido a su importancia económica en Colombia, a su elevada disponibilidad para las poblaciones más desfavorecidas y a su riqueza en fitoquímicos específicos como la espermidina, resulte interesante para el desarrollo de alimentos medianamente procesados de alto valor nutritivo y con efecto preventivo sobre la obesidad y la hipertensión. Además, dado que el fruto solo se consume en forma de zumo, la aplicación de un tratamiento de HPH ayudaría a mejorar sus propiedades nutricionales 
El tratamiento de HPH tiene un gran interés para mejorar las propiedades físico-químicas y funcionales de los zumos de frutas, aumentando la estabilidad de los mismos y mejorando su perfil fitoquímico. Multitud de estudios científicos demuestran que puede sustituir o al menos reducir los tratamientos térmicos tradicionales; ya que resulta lo suficientemente eficaz para inactivar los microorganismos responsables del deterioro siendo menos destructivo para los compuestos de bajo peso molecular responsables de los atributos sensoriales y nutricionales.

Se determinaron las características macroestructurales, los parámetros de impregnación, y las propiedades fisicoquímicas y antioxidantes (capacidad antioxidante, contenido de fenoles totales $y$ flavonoides, perfil de compuestos polifenólicos por LC-MS y contenido en espermidina) del fruto del lulo. Además, se evaluó el efecto de las presiones de homogeneización (50, 100 y $150 \mathrm{MPa}$ ) sobre las mismas propiedades del zumo.

Los resultados del trabajo de investigación se publicaron en la revista Foods (ISSN: 2304-8158; Current Impact Factor: 4.350; 5-year Impact Factor: 4.957; JCR category rank: Q2: Food Science \& Technology).

Hinestroza-Córdoba, L.I.; Barrera, C.; Seguí, L.; Betoret, N. Potential Use of Vacuum Impregnation and High-Pressure Homogenization to Obtain Functional Products from Lulo Fruit (Solanum quitoense) Foods 2021, 10, 817. https://doi.org/10.3390/foods10040817.

Los resultados obtenidos mostraron el lulo como una fruta con propiedades físico-químicas y funcionales ventajosas para el desarrollo de productos alimenticios saludables a partir de recursos autóctonos de la región del Pacífico colombiano. Sus características estructurales determinadas indirectamente a partir de los parámetros de impregnación permiten la incorporación de protectores, conservantes, compuestos fisiológicamente activos u otros aditivos. Esta incorporación está ligeramente influenciada por el índice de madurez, pero no por la variabilidad entre frutos. La caracterización microestructural del fruto por 
Cryo-SEM permitió comprobar la disponibilidad de espacios intercelulares, poros, canales y/o huecos lo suficientemente grandes como para poder incorporar tanto componentes bioactivos en disolución acuosa como microorganismos probióticos por IV.

El perfil polifenólico obtenido por LC-MS, reveló la presencia de 288 compuestos pertenecientes a diferentes clases fenólicas (principalmente flavonoides y ácidos hidroxicinámicos). Además, el aumento de la presión del tratamiento de HPH incrementa la diversidad de polifenoles del zumo. Adicionalmente, se identificaron en las muestras de fruta y de zumo, aminas bioactivas como la N, N, N-tris (dihidrocafeoil) espermidina y la N, N-bis (dihidrocafeoil) espermidina, cuyo efecto contra la hipertensión se ha demostrado en estudios anteriores. En relación con la capacidad antiradical aportada por los compuestos antioxidantes, ésta disminuye en el zumo fresco en comparación con la fruta, debido a la retención de parte de los sólidos en la operación de filtrado. Sin embargo, cabe mencionar que la HPH a 100-150 MPa es adecuada para preservar la capacidad antiradical de la fruta aumentando el valor antioxidante del zumo fresco.

4. Determinar las posibilidades de obtener un zumo de lulo fermentado con microorganismos probióticos con efecto potencial contra la obesidad. Evaluar el efecto del crecimiento de estos sobre las propiedades del zumo.

Diferentes estudios demuestran que los zumos de frutas son una buena matriz para la proliferación de probióticos debido a su contenido en hidratos de carbono, vitaminas y compuestos bioactivos. Además, unido al consumo de frutas, la ingesta de ciertos microorganismos es capaz de disminuir la grasa corporal al modificar la microbiota intestinal, estimular la síntesis de péptidos inductores de la saciedad, reducir la síntesis de citoquinas proinflamatorias y posiblemente modificar el perfil lipídico. En este contexto, los zumos de frutas tropicales, como el zumo de lulo, fermentados con probióticos pueden ser una estrategia eficaz para satisfacer las necesidades de salud asociadas a la dieta. 
Sin embargo, se sabe que la supervivencia de las bacterias lácticas en los zumos de frutas tiende a ser más compleja que en los lácteos. Esto se debe, principalmente, a la acidez natural de la fruta, al alto nivel de polifenoles y a la ausencia de lactosa, que puede interferir en la supervivencia de ciertos tipos de microorganismos, así como en su crecimiento y también en su resistencia al proceso de digestión gastrointestinal. Por este motivo, es fundamental, además de seleccionar la cepa más adecuada para cada sustrato, añadir otros ingredientes en la formulación (prebióticos, crioprotectores, extracto de levadura, etc.) y/o aplicar determinadas técnicas durante el procesado (microencapsulación, homogeneización a presiones moderadas, impregnación al vacío, etc) que aumenten la supervivencia del microorganismo y su resistencia al proceso de digestión gastrointestinal.

Lactobacillus reuteri es una bacteria láctica heterofermentativa cuyo consumo como suplemento ha sido reconocido como seguro. Además, Lactobacillus reuteri mostró una mejora de los biomarcadores de inflamación y riesgo cardiovascular en adultos obesos con síndrome metabólico. También, se ha demostrado que tiene la capacidad de fermentar toda una serie de fuentes de carbono diferentes y algunas especies se han utilizado para fermentar zumos de frutas, produciendo durante la fermentación compuestos bioactivos de gran interés como los folatos y la vitamina B12 y la reuterina. La reuterina es un compuesto con potencial como conservante de alimentos, especialmente por su actividad contra la bacteria Listeria monocytogenes y Escherichia coli. En definitiva, sus características y su condición de inocuo convierten a $L$. reuteri en un organismo prometedor en la industria alimentaria.

Se planteó un estudio que permitiera evaluar el uso del zumo de lulo como sustrato para producir una bebida probiótica con Lactobacillus reuteri. Se consideraron zumos de lulo a dos niveles de $\mathrm{pH}$ y dos niveles de tratamiento con HPH y se evaluó el efecto sobre el crecimiento de $L$. reuteri, las propiedades fisicoquímicas y antioxidantes y la resistencia de las células microbianas a la digestión gastrointestinal in vitro. 
Los resultados han sido publicados en la revista Applied Sciences (ISSN: 2076-3417; Current Impact Factor: 2.679; 5-year Impact Factor: 2.736, JCR category rank: Q2: Engineering, Multidisciplinary / Q2: Physics, Applied).

Hinestroza-Córdoba, L. I., Barrera, C., Seguí, L., Betoret, E., \& Betoret, N. (2020). Fermentation of lulo juice with Lactobacillus reuteri CECT 925. Properties and effect high homogenization pressures on resistance to in vitro gastrointestinal digestion. Applied Sciences 2021,11(22)10909. https://doi.org/10.3390/app112210909

Los resultados obtenidos pusieron de manifiesto que el zumo de Iulo es una matriz adecuada para que Lactobacillus reuteri CECT 925 pueda llevar a cabo la fermentación dando lugar a un zumo con potenciales propiedades probióticas. Las condiciones más favorables para la obtención de un mayor contenido en células vivas se dieron en aquellos zumos que se sometieron a presiones de homogeneización de $100 \mathrm{MPa}$ y con el pH rectificado a 5,5. Las propiedades fisicoquímicas y antioxidantes de los zumos se vieron modificadas después de 24 horas de fermentación con Lactobacillus reuteri CECT 925. A mayor crecimiento microbiano, mayor tamaño de partícula y mejores propiedades antioxidantes de los zumos.

Lactobacillus reuteri CECT 925 demostró ser un microorganismo con buena capacidad de resistencia a las condiciones desfavorables de la digestión gastrointestinal in vitro. Su resistencia se vio condicionada fundamentalmente por el contenido de células viables en los zumos iniciales. Aunque los niveles de viabilidad fueron mayores en los zumos homogeneizados a $100 \mathrm{MPa}$ y $\mathrm{pH}$ 5,5, en todas las muestras se logró una concentración mínima de $10^{7} \mathrm{UFC} / \mathrm{mL}$ al final del ensayo, concentración suficiente para que el microorganismo pueda ejercer sus efectos beneficiosos para la salud en el tracto intestinal del huésped.

A continuación, se presentan las publicaciones (versión de autor) referenciadas en este capitulo. 
Resultados y discusión 


\section{Probiotics and other Bioactive Compounds with Proven Effect against Obesity and Hypertension. Food Design Opportunities from Lulo Fruit (Solanum quitoense)}

Noelia Betoret ${ }^{1}$, Leidy Indira Hinestroza ${ }^{2}$, Lucía Seguí ${ }^{1}$, Cristina Barrera ${ }^{1}$

1 Institute of Food Engineering for Development, Universitat Politècnica de València, CP 46022 València, Spain.

2 Grupo de Valoración y Aprovechamiento de la Biodiversidad, Universidad Tecnológica del Chocó. AA.292, Calle 22 No. 18B-10, Quibdó-Chocó, CP 270001 Colombia.

Nutraceuticals Past, Present and Future. InterOpen

ISBN: 978-1-83881-162-4

DOI: 10.5772 /intechopen.78440

\section{Abstract}

This book chapter aims to identify those bioactive compounds that are the most effective in obesity and hypertension prevention and/or treatment, these being the two main disorders associated with metabolic syndrome. Focusing on probiotics and phytochemicals, the document will provide evidences from both in vitro and in vivo studies, as well as information about the action mechanisms and how they are affected by the interaction with other food ingredients, the food matrix in which they are placed, etc. Given its high antioxidant capacity, in part due to its spermidine content, lulo fruit has generated considerable interest among health researchers. This, together with its exotic organoleptic properties, offers interesting growth opportunities for the design of new food products from lulo fruit. This book chapter will also discuss some of them.

Keywords: probiotics; phytochemicals; metabolic syndrome; spermidine; Iulo

\section{Foods, technology and metabolic syndrome}

Overweight and obesity are defined as "abnormal or excessive fat accumulation that may impair health" [1]. Since 1975, obesity has almost tripled worldwide so that in $2016,39 \%$ of the adult population and $18 \%$ of 
children and adolescents were overweight. Very often, a high body mass index (BMI $\geq 25-30$ ) is associated with other metabolic abnormalities, such as high blood pressure (hypertension), high blood sugar (hyperglycemia), high serum triglycerides and low serum high density lipoprotein (HDL) [2]. The occurrence of at least three of these interconnected physiological, biochemical, clinical, and metabolic factors that directly increase the risk of atherosclerotic cardiovascular disease, cancer and type-2 diabetes is known as metabolic syndrome [3]. The International Diabetes Federation estimates that one-quarter of the world's adult population suffers from this syndrome, with little difference between developed and developing countries. Main factors contributing to it include, beyond the genetic susceptibility, the increased consumption of calorie-dense food and the scarce physical activity. Given that metabolic syndrome can occur in several forms, according to the combination of the different components, it is apparently difficult to treat it pharmacologically, being lifestyle change the most effective preventive approach. However, the fact that a lowgrade chronic inflammatory state accompanies the metabolic syndrome in any of its forms suggests that anti-inflammatory therapies could have a place in its prevention and treatment [4].

Inflammation is a response of the body's immune system to harmful stimuli. In the case of metabolic syndrome, inflammation takes place in response to imbalance of blood glucose and insulin levels or insulin resistance, what leads to unhealthy high concentration of unused sugar in the bloodstream that is send to the liver, muscle or pancreas [5, 6]. Once there, the sugar is converted into fat, thus leading to progressive adipocyte enlargement. Hypertrophy reduces blood supply to adipocytes and causes hypoxia. Subsequent necrosis and macrophage infiltration into adipose tissue leads to overproduction of reactive oxygen species (ROS), low density lipoproteins (LDLs), inflammatory cytokines (tumor necrosis factor-alpha, interleukin-6, adiponectin, etc.) and C-reactive protein (CRP). High-fat diets, frequently consumed by obese individuals, aggravate this problem both directly, when the fat is rich in saturated fatty acids, and indirectly, through effects on the microbiota and intestinal permeability [5]. The normal blood plasma concentration of CRP varies between 0.08 $\mathrm{mg} / \mathrm{dL}$ and $0.3 \mathrm{mg} / \mathrm{dL}$ in healthy adults and reaches values between 2 and $10 \mathrm{mg} / \mathrm{dL}$ in individuals suffering from metabolic syndrome. High levels of 
the inflammatory marker CRP in blood is associated with increased odds of having plaque in the carotid arteries and therefore, with increased risk of myocardial infarction and stroke [7].

In addition to CRP, some dietary food components involved as intermediates in various metabolic pathways appear altered in population with metabolic syndrome, making possible its use as biomarkers. Polyunsaturated fatty acids (PUFA), specifically eicosapentaenoic acid (20:5 n-3; EPA) and docosahexaenoic acid (22:6 n-3; DHA), are inversely related to metabolic syndrome in adults [8]; several studies have stablished an association between this syndrome and selenium blood concentration [9] or serum levels of vitamin B12 [10]; Urrunaga-Pastor et al. [11] also found an association between vitamin $D$ deficiency and hyperinsulinemia; adults with metabolic syndrome also have suboptimal concentrations of several antioxidants (retinyl esters, vitamin C, and all carotenoid concentrations, except lycopene), partly due to the lower intake of fruit and vegetables by these individuals [12]. These results reinforce the relationship between diet and the incidence of metabolic syndrome.

Evidence from prospective observational in vitro and in vivo studies (preclinical and clinical trials) has converged to support the importance of individual nutrients or foods intake, and dietary patterns in the prevention and management of obesity and metabolic syndrome. In vitro studies seek to determine the biochemical mechanisms at the cellular level as physiological ones, which are involved in the proper functioning both at the transcriptional and protein expression in pancreas, skeletal muscle, liver and adipose tissue. In vivo studies allow establishing a causeeffect relationship in experimental animals (preclinical trials) or in humans (clinical trials). While in vitro or animal in vivo studies are standardized and there are countless works done, even today a standard profile for clinical trials in humans with metabolic syndrome has not yet been established. Clinical trials about therapeutic efficacy for metabolic syndrome are scarce and concentrated in the last 8 years in high-income countries (USA, Italy and Spain). Interventions that affect three or more factors and evaluate various outcome variables are reduced, highlighting the lifestyle factors (diet and physical activity) as the most important in this multifactorial 
syndrome [13]. Specifically, a low intake of saturated and total fat; reduced consumption of sodium, simple sugars and high glycemic index foods; and increased intake of fruits, vegetables, legumes, and whole grains are suggested to be the most effective actions in reducing the incidence of obesity and cardiovascular disease. However, the urban lifestyle leads us to mainly consume foods in processed form, what reinforces the decisive role that the food industry plays in the promotion of healthy diets. In fact, in recent years the supply of functional foods with a reduced content of fat, sugar or salt, as well as that of functional foods formulated with phytosterols or polyunsaturated fatty acids has increased considerably.

In order to achieve this, not only traditional techniques of food formulation and blending or cultivation and breeding are involved, but also more recent ones, such as microencapsulation, vacuum impregnation or coating with edible films [14]. Moreover, the increasing knowledge about the negative impact that processing and cooking techniques have on the concentration and functionality of the active compounds naturally present in foods has encouraged the use of alternative techniques, such as the application of high-pressure homogenization replacing the pasteurization or freeze-drying instead of hot air drying.

Later in this book chapter, the most relevant bioactive compounds with proven effect against any disorder associated with the metabolic syndrome are listed. Focusing on probiotic microorganisms and phytochemical compounds, evidences obtained from in vitro, in vivo or clinical studies in the last 10 years have been compiled. Finally, new functional foods made from lulo fruit are suggested as suitable for metabolic syndrome prevention and/or amelioration.

\section{Food components against metabolic syndrome}

Main food components considered in the literature as potential ameliorating effect on any disorder associated with metabolic syndrome may be included in one of the following groups:

- $\quad$ Fiber, both soluble (e.g. pectins, beta-glucans, naturally-occurring gums, inulin, psyllium) and insoluble (e.g. cellulose, hemicellulose, 
lignin), is reported to have laxative properties and to mitigate both hypercholesterolemia and hyperglycemia [15]. When fermented by probiotic bacteria, prebiotic fiber (fiber that resists digestion in the stomach and the small intestine and reaches the colon intact) breaks down into short-chain fatty acids (butyrate, acetate and propionate), which are reported to enhance glucose and fat metabolism [16].

- Monounsaturated fats, polyunsaturated fats (both omega-3 and omega-6), plant sterols and essential fatty acids instead of saturated fats and trans fatty acids are proved to be effective in decreasing total cholesterol and increasing the blood level of high density lipoproteins (HDLs) [17].

- Vitamins $E$ and $C$ consumption is associated to a reduction of vascular risk by decreasing oxidative stress (lipid peroxidation) and proinflammatory cytokines [17]. Improved vitamin C status is hypothesized to alleviate endotoxemia and its consequent proinflammatory responses that are suggested to initiate insulin resistance and related metabolic disorders; on the contrary, inadequate vitamin $\mathrm{C}$ status contributes to small intestinal bacterial overgrowth, transcytosis of enteric bacteria, and an elevation of circulating lipopolysaccharide, which elicits a lowgrade inflammatory response [18]. As for vitamin $D$, it reduces the intestinal absorption of fat by increasing that of calcium [17].

- Bioactive peptides, having size range in 2-50 amino acids, have potential to regulate blood pressure and glycemia, reduce cholesterol level and body mass, and scavenge free radicals [19]. Lactotripeptides isoleucine-proline-proline and valine-prolineproline, whose concentration increase during the ripening process of cheese, are particularly considered as strong antihypertensive agents [20]. In the case of obesity, foods that contain bioactive peptides provide a satiating effect and lead to appetite suppression. 
- Minerals (selenium, magnesium and zinc) ability to decline metabolic syndrome is related with their antioxidant properties and their participation in insulin synthesis and regulation [20]. Moreover, calcium intake ( $1200 \mathrm{mg} /$ day) has been demonstrated to increase fat mass lose in overweight and obese adults [21]. Mechanisms to explain this effect include that during low calcium intake, more calcium enters adipose tissues cells and subsequently stimulates the expression of lipogenic genes in parallel with suppressing lipolysis [22]. Also, calcium increases faecal fat loss by binding to fat in the lumen and forming nonabsorbed complexes [23]. This ability of calcium to decrease lipogenesis may be enhanced due to a synergistic effect with other components in dairy products (vitamin D and angiotensinconverting enzyme inhibitors) [21].

- Essential amino acids, mainly histidine and glycine, are associated with a decrease in insulin resistance and blood pressure, respectively, although conclusive evidence is lacking and additional studies are needed [17].

- Phytochemicals, mainly polyphenols (phenolic acids, curcuminoids, stilbenes, lignans, flavonoids, flavonols, flavones, anthocyanins, etc.) but also other bioactive components present in small quantities in fruits and vegetables (triterpenes, carotenoids, etc.) have demonstrated anti-inflammatory, antioxidative, antiadiposity and cardioprotective functions in a huge amount of studies [24-28]. Some phytochemicals, among which are caffeine, ephedrine, capsaicin and salicylic acid, also act as thermogenic compounds that produce heat from lipids and fats, thus burning extra calories and preventing the accumulation of fat in body tissues [20].

- $\quad$ Probiotics are microorganisms that improve the availability and digestibility of nutrients while maintaining the balance of intestinal microflora in the gut [20]. Mainly belonging to the Lactobacillus and Bifidobacterium genera, probiotics emerge as prospective biotherapies in the management of metabolic 
disorders including obesity and diabetes by counteracting the adverse effects of a high-fat diet [29].

\subsection{Phytochemicals}

Phytochemicals are naturally occurring plant chemicals that, beyond providing plants with color, odor and flavour, can influence chemical processes within human bodies in a beneficial way. Main phytochemicals under research include carotenoids ( $\beta$-carotene, lycopene, lutein, zeaxanthin) and polyphenols, which include phenolic acids, flavonoids, and stilbenes/lignans [30]. Flavonoids can be further divided into groups based on their similar chemical structure, such as anthocyanins, flavones, flavanones, and isoflavones, flavonols and flavanols. Flavanols further are classified as catechins, epicatechins, and proanthocyanidins.

Phytochemical compounds have gained popularity in recent years due to their broadly documented effect in cancer prevention among other biological effects, such as the prevention and treatment of obesity, cholesterol and diabetes [31]. Mechanisms employed by phytochemicals in ameliorating metabolic syndrome risk factors are diverse and dependent on their particula chemical structure. Whereas catequins mainly induce fat oxidation and improve endothelial function, cyanidins and theaflavins inhibit enzymes involved in the synthesis of fatty acids and triglycerides. Other phytochemicals, such as gallic acid, quercetin and capsaicin, reduce preadipocytes proliferation by induction of cell apoptosis, while low molecular proantocyanidins have the ability to inhibit the activity of specific angiotensin-converting enzyme. Having a similar chemical structure, isoflavones can also influence the activity of human estrogens.

For some bioactive components, several in vitro and in vivo (either animals or humans) studies have been performed; however, as evidenced in tables 1-3, results differ among them. While in vitro or animal studies usually yield positive results, clinical human studies are still inconclusive. The lack of standardization or aspects related to the dose or duration of supplementation may be the cause of these results. 
Table 1. Fruits, vegetables (or extracts) and phytochemicals endorsed by recent in vitro studies.

\begin{tabular}{|c|c|c|c|}
\hline Phytochemical(s) & Methodology & Beneficial effect(s) & Reference \\
\hline Synthesis naringenin & $\begin{array}{l}\text { 3T3-L1 cell lineand } \\
\text { Pemphigus vulgaris- } \\
\text { treated HaCaT cell line }\end{array}$ & $\begin{array}{l}\text { Anti-adipogenic, antioxidant,ant } \\
\text { inflammatory and antiapoptosi } \\
\text { effects }\end{array}$ & {$[32,33]$} \\
\hline $\begin{array}{l}\text { Pentacyclic triterpenes } \\
\text { (oleanolic acid, 18ß- } \\
\text { glycyrrhetinic acid, ursolic } \\
\text { acid, celastrol, maslinic } \\
\text { acid, ilexgenin A) }\end{array}$ & $\begin{array}{l}\text { 3T3-L1 cell line or10T1/2 } \\
\text { cells and primary fat SVF } \\
\text { cells or HepG2 cells }\end{array}$ & $\begin{array}{l}\text { Decreased obesity-induce } \\
\text { inflammation, stimulated lipolysisan } \\
\text { decreased adipocyte differentiation }\end{array}$ & [26] \\
\hline Synthesis carvacrol & Cyclooxygenase- 2 assay & Anti-inflammatory potential & [34] \\
\hline $\begin{array}{l}\text { Spermidine (from } \\
\text { ethanolic lulo pulp extract) }\end{array}$ & $\begin{array}{l}\text { In vitro measurement of } \\
\text { angiotensin-converting } \\
\text { enzyme inhibition }\end{array}$ & Hypertension control & [35] \\
\hline $\begin{array}{l}\text { Flavonoids (naringenin, } \\
\text { rutin, hesperidin, } \\
\text { resveratrol, naringin, and } \\
\text { quercetin) }\end{array}$ & 3T3-L1 cell line & $\begin{array}{l}\text { Quercetin efficiently inhibited ce } \\
\text { population growth and increase } \\
\text { induction of apoptosis }\end{array}$ & {$[36]$} \\
\hline Resveratrol & $\begin{array}{l}\text { Maturing preadipocytes } \\
\text { and adipocytes }\end{array}$ & $\begin{array}{l}\text { Decreased adipogenesis, } \\
\text { increased lipolysis, induced apoptosi: } \\
\text { and reduced lipogenesis an } \\
\text { proliferation, thereby contributing t } \\
\text { reduce lipid accumulation. Reduce } \\
\text { inflammatory response and improve } \\
\text { insulin sensitivity }\end{array}$ & {$[37]$} \\
\hline Ajoene & Mature 3T3-L1 adipocytes & $\begin{array}{l}\text { Influenced the regulation of fat ce } \\
\text { number }\end{array}$ & [38] \\
\hline Green tea catechins & 3T3-L1 cells & $\begin{array}{l}\text { Increased apoptosis and decrease } \\
\text { preadipocyte proliferation }\end{array}$ & [27] \\
\hline
\end{tabular}

Table 2. Fruits, vegetables (or extracts) and phytochemicals endorsed by recent in vivo (preclinical trials) studies.

\begin{tabular}{|c|c|c|c|}
\hline Phytochemical(s) & Methodology & Beneficial effect(s) & Reference \\
\hline Naringenin & Rats and mice & 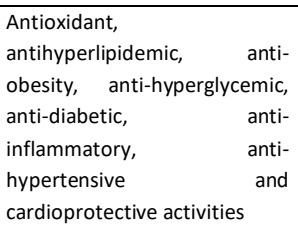 & [39] \\
\hline
\end{tabular}




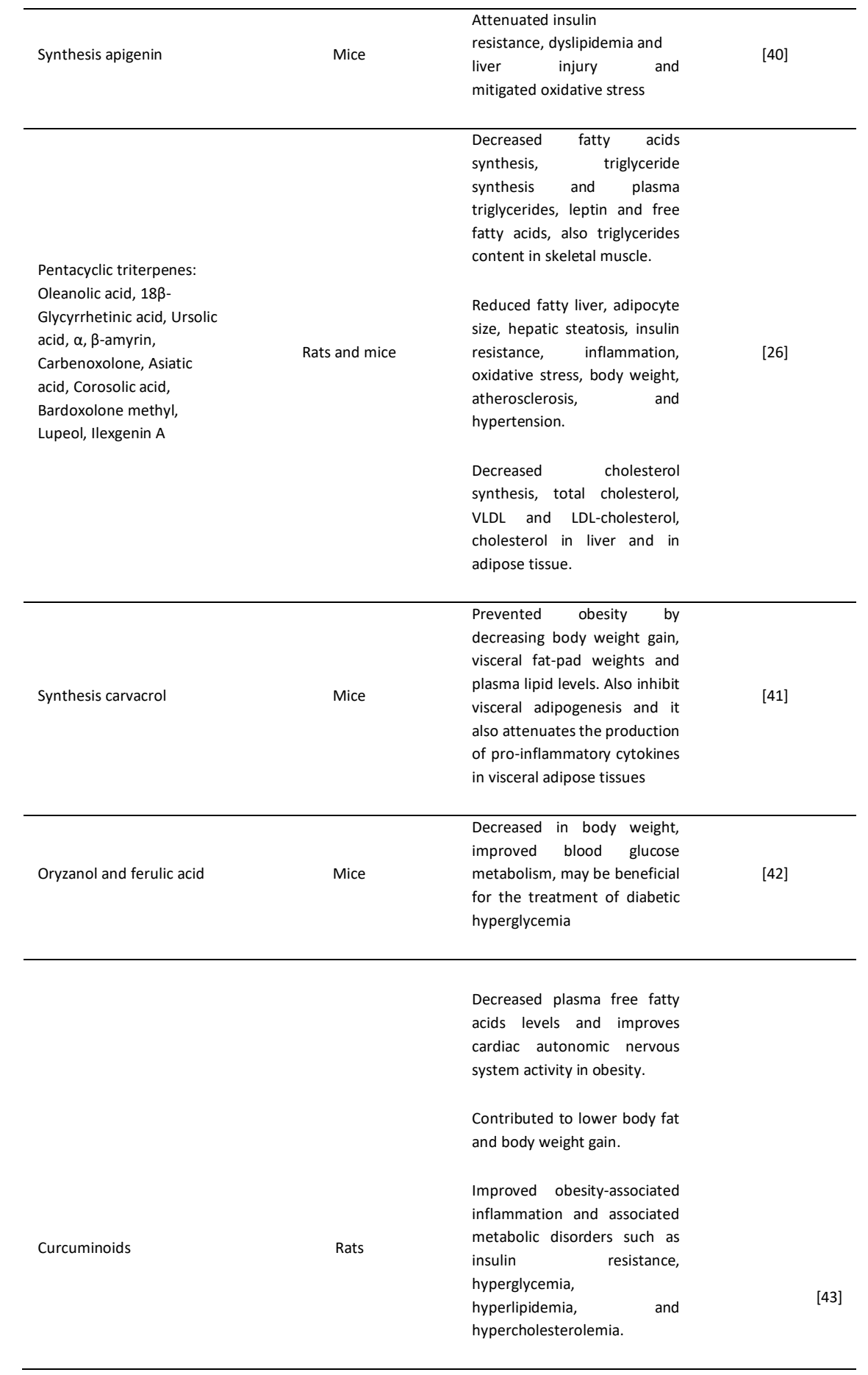




\begin{tabular}{|c|c|c|c|}
\hline Quercetin & Rats and mice & $\begin{array}{l}\text { Decreased body weight, } \\
\text { visceral fat, and blood glucose, } \\
\text { free cholesterol, total } \\
\text { antioxidant status, lipid } \\
\text { accumulation and systolic } \\
\text { blood pressure }\end{array}$ & [24] \\
\hline Green tea catechins & Rats and mice & $\begin{array}{l}\text { Decreased body weight, total } \\
\text { lipids, cholesterol, and } \\
\text { triglycerides in liver and } \\
\text { plasma. Also improved glucose } \\
\text { homeostasis: increased } \\
\text { glucose tolerance and } \\
\text { decreased serum glucose, } \\
\text { insulin resistance and } \\
\text { homeostasis } \\
\begin{array}{ll}\text { assessment of insulin } \\
\text { resistance }\end{array}\end{array}$ & [27] \\
\hline
\end{tabular}

\subsection{Probiotics}

Probiotics are defined as live microorganisms which, when administered in adequate amounts, confer a health benefit on the host [50]. Regarding the management of several inflammatory diseases, main strains with potential effect belong to the Lactobacillus and Bifidobacterium genera, although Pediococcus pentosaceus LP28, Bacteroides uniformis CECT 7771 and Akkermansia muciniphila have also been proved to have anti-obesity effects [51].

Amongst the potential mechanisms involved, it is worth noting the increase in the bacterial diversity of intestinal microflora. Recent research relates gut microbiota composition with almost every chronic disease: from gastrointestinal diseases, to obesity, diabetes, cancer and even neurological and neurodegenerative disorders such as depression, autism, anxiety and Parkinson's disease [52]. Not only a certain microbiota predisposes to suffer certain diseases, but also the incidence of a certain disorder modifies the gut microbiota of an individual. In overweight/obese subjects, Bacteroides, Parabacteroides, Ruminococcus, Campylobacter, Dialister, Porphyromonas, Staphylococcus and Anaerostipes are the dominant genera linked to a low diversity of species; while Faecalibacterium, Bifidobacterium, Lactobacillus, Butyrivibrio, Alistipes, Akkermansia, Coprococcus and Methanobrevibacter are predominant in lean individuals with a high bacterial diversity [53]. Apparently, the 
intestinal microflora of obese subjects is more efficient at extracting energy from a given diet than that of lean individuals, thus leading to increased energy storage and adiposity [51]. Moreover, beneficial intestinal microflora is known to produce short chain fatty acids (e.g., acetate, butyrate and propionate) from indigestible polysaccharides, which may act as energy substrates, as well as regulators of satiety and food intake. Last but not least, Lactobacilli and Bifidobacteria are known to synthesize bioactive isomers of conjugated linoleic acid with antidiabetic, anti-atherosclerotic, immunomodulatory, and anti-obesity properties [54]. In other words, low bacterial diversity in obese individuals is associated with a reduction in butyrate-producing bacteria, a reduction in hydrogen and methane production, an increase in mucus degradation and an increase in the potential to manage oxidative stress.

Since intestinal microflora composition is strongly affected by dietary patterns, many studies evaluate the effect of certain food components on the growth of bacteria with beneficial effect on metabolic syndrome and obesity, particularly Akkermansia muciniphila and Faecalibacterium prausnitzii. Increasing the intestinal population of these two species has become a real opportunity to decrease alterations associated with obesity and metabolic disorders [55]. Together with increasing gut microbiota diversity, the production by fermentative action of those bioactive molecules involved in the metabolic pathways that trigger the metabolic syndrome has also taken a lot of interest in the last years.

In particular, many studies focuses on the phenolic compounds bioconversion by food fermentation into other components with greater beneficial effect on the abnormalities associated with metabolic syndrome. As an example, Wang et al. [56] proved that the use of Lactobacillus paracasei subsp. paracasei strain NTU 101 in the fermentation of green tea and Houttuynia cordata leaves increased the levels of epigallocatechin gallate (EGCG), epigallocatechin (EGC) and chlorogenic acid, which enhanced the probiotic effect on body fat reduction. These results show the synergistic or complementary effect between the two bioactive compounds: the probiotic strain increases gut microbiota diversity and enhances intestinal absorption, while the EGCG 
acid promotes the lipolysis process. Zarreti et al. [57] also reported a synergistic effect between a weight-loss diet and probiotic yogurt in overweight and obese individuals.

It should be noted that in order to exert their health beneficial, probiotics do not necessarily have to be alive. In fact, heat-killed Lactobacillus reuteri GMNL 263 was as effective as live Lactobacillus reuteri GMNL 263 in attenuating obesity-induced metabolic abnormalities in high-fat diet-induced rats by reducing insulin resistance and hepatic steatosis formation [58]. Also, both heat-killed Lactobacillus plantarum strain Ln4 and freeze-dried cultured MRS broth significantly reduced lipid accumulation and stimulated glucose uptake in 3T3-L1 adipocytes [59]. Finally, Plovier et al. [60] found that pasteurization enhanced the capacity of Akkermansia muciniphila to reduce fat mass development, insulin resistance and dyslipidemia in mice. It seems that a specific protein isolated from the outer membrane of Akkermansia muciniphila is stable at temperatures used for pasteurization, and improves the gut barrier, thus being the main responsible factor of the beneficial effect of the bacteria on health. Tables 4 and 5 compile evidence from the latest studies in which probiotic efficiency in metabolic disorder management is assessed both in vitro and in animal or human subjects.

Table 4. Probiotic strains endorsed by in vitro and animal studies.

\begin{tabular}{|c|c|c|c|}
\hline Probiotic organism & Methodology & Beneficial effect(s) & Reference \\
\hline & 3T3-L1 adipocytes & $\begin{array}{l}\text { Reduces lipid accumulation and } \\
\text { stimulates glucose uptake }\end{array}$ & \\
\hline $\begin{array}{l}\text { Lactobacillus plantarum Ln4 } \\
\text { obtained from napa cabbage } \\
\text { kimchi }\end{array}$ & $\begin{array}{c}\text { Mice fed on a high-fat } \\
\text { diet }\end{array}$ & $\begin{array}{l}\text { Reduces weight gain, epididymal fat } \\
\text { mass, insulin resistance index; and } \\
\text { improves glucose tolerance and insulin } \\
\text { response }\end{array}$ & [59] \\
\hline $\begin{array}{l}\text { Lactobacillus } \\
\text { reuteri } 263 \text { patented strain }\end{array}$ & $\begin{array}{l}\text { Rats fed on a high- } \\
\text { energy diet }\end{array}$ & $\begin{array}{l}\text { Reduces obesity by decreasing pro- } \\
\text { inflammation factors and } \\
\text { increasing antioxidant enzymes in the } \\
\text { serum }\end{array}$ & [61] \\
\hline \multirow{2}{*}{$\begin{array}{l}\text { Lactobacillus paracasei subsp. } \\
\text { paracasei NTU } 101 \text { originally } \\
\text { isolated from infant }\end{array}$} & $\begin{array}{l}\text { 3T3-L1 pre-adipocyte } \\
\text { model }\end{array}$ & $\begin{array}{l}\text { Promotes lipase activity in adipocytes, } \\
\text { which thereby improves the lipolytic } \\
\text { effect }\end{array}$ & {$[56]$} \\
\hline & Obese rat model & Body fat reduction & \\
\hline
\end{tabular}




\begin{tabular}{|c|c|c|c|}
\hline $\begin{array}{l}\text { Lactobacillus fermentum strain } \\
\text { 4B1 isolated from fermented } \\
\text { shrimp }\end{array}$ & $\begin{array}{c}\text { Mice fed with high-fat } \\
\text { diet }\end{array}$ & $\begin{array}{l}\text { Reduces adipose cell areas, body } \\
\text { weights and adipose tissue weights }\end{array}$ & [62] \\
\hline 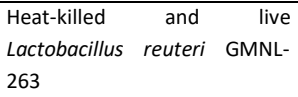 & $\begin{array}{l}\text { Rats fed with high-fat } \\
\text { diet }\end{array}$ & $\begin{array}{l}\text { Both heat-killed and live Lr263 could } \\
\text { suppress inflammatory response and } \\
\text { the expressions of specific citokines }\end{array}$ & [58] \\
\hline Akkermansia muciniphila & $\begin{array}{l}\text { Obese and diabetic } \\
\text { mice }\end{array}$ & $\begin{array}{l}\text { Reduces high fat induced body weight } \\
\text { and fat mass gain; also, improves } \\
\text { glucose intolerance and insulin } \\
\text { resistance }\end{array}$ & [60] \\
\hline $\begin{array}{l}\text { Bifidobacterium } \\
\text { pseudocatenulatum SPM 1204, } \\
\text { Bifidobacterium longum SPM } \\
1205 \text {, and Bifidobacterium } \\
\text { longum SPM } 1207 \text { isolated } \\
\text { from healthy Koreans fecal } \\
\text { samples }\end{array}$ & $\begin{array}{l}\text { Fat diet-induced } \\
\text { obese rats }\end{array}$ & $\begin{array}{l}\text { Reduces body and fat weights, blood } \\
\text { serum levels, and harmful enzyme } \\
\text { activities }\end{array}$ & [63] \\
\hline $\begin{array}{l}\text { Lactobacillus reuteri ATCC PTA } \\
\text { 4659, DSM } 17938 \text { and L6798 }\end{array}$ & Fat diet-induced mice & $\begin{array}{l}\text { Lactobacillus reuteri ATCC partly } \\
\text { prevented diet-induced obesity }\end{array}$ & [64] \\
\hline $\begin{array}{l}\text { Pediococcus pentosaceus LP28 } \\
\text { isolated from longan fruit }\end{array}$ & $\begin{array}{l}\text { Induced obesity } \\
\text { mice }\end{array}$ & $\begin{array}{l}\text { Live probiotic reduces obesity, but heat- } \\
\text { killed is ineffective to reduce obesity }\end{array}$ & [65] \\
\hline
\end{tabular}

Table 5. Probiotic strains endorsed by in vivo studies.

\begin{tabular}{|c|c|c|c|}
\hline Probiotic organism & Methodology & Beneficial effect(s) & Reference \\
\hline 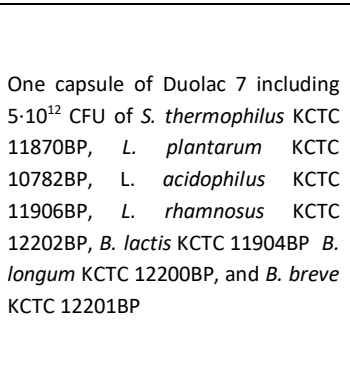 & $\begin{array}{l}\text { A randomized, double-blinded, } \\
\text { placebo controlled study in } 50 \\
\text { female with } \mathrm{BMI}>25 \mathrm{~kg} / \mathrm{m}^{2} \text { and } \\
\text { waist circumference }>85 \mathrm{~cm}\end{array}$ & $\begin{array}{l}\text { HDL cholesterol level exhibited } \\
\text { a significant difference } \\
\text { between the probiotics and } \\
\text { placebo group. } \\
\text { Bifidobacterium breve was the } \\
\text { only strain showing a } \\
\text { significant tendency of } \\
\text { declination of endotoxin level, } \\
\text { which could be suggested as a } \\
\text { promising probiotic strain } \\
\text { specified for obesity treatment }\end{array}$ & [66] \\
\hline $\begin{array}{l}\text { L. rhamnosus CGMCC1.3724 (LPR) } \\
\text { in capsules with oligofructose and } \\
\text { inulin ( } \approx 1 \text { to } 6 \cdot 10^{8} \mathrm{CFU} / \text { capsule) }\end{array}$ & $\begin{array}{l}\text { A double-blind, placebo- } \\
\text { controlled, randomized trial in } \\
\text { subjects with } 41 \mathrm{~kg} / \mathrm{m}^{2}>\mathrm{BMI}> \\
29 \mathrm{~kg} / \mathrm{m}^{2} \text { consuming two } \\
\text { capsules per day }\end{array}$ & $\begin{array}{l}\text { LPR supplementation } \\
\text { accentuated body-weight loss } \\
\text { in women submitted to energy } \\
\text { restriction; this effect } \\
\text { persisted in the subsequent } \\
\text { maintenance phase, when } \\
\text { energy restriction was not } \\
\text { further imposed }\end{array}$ & [67] \\
\hline $\begin{array}{l}\text { L. plantarum TENSIA (DSM 21380) } \\
\text { isolated from the gastrointestinal } \\
\text { tract of healthy Estonian children }\end{array}$ & $\begin{array}{l}\text { A randomized, double-blind, } \\
\text { placebo- controlled, parallel- } \\
\text { designed study in } 40 \text { subjects } \\
\text { with metabollic syndrome }\end{array}$ & $\begin{array}{l}\text { The hypocaloric diet } \\
\text { supplemented with }\end{array}$ & [68] \\
\hline
\end{tabular}




\begin{tabular}{lll}
\hline $\begin{array}{l}\text { added to cheese milk in amounts of } \\
1.5 \cdot 10^{11} \mathrm{CFU} / \mathrm{g} \text { before renneting }\end{array}$ & $\begin{array}{l}\text { consuming the standard } \\
\text { hypocaloric diet supplemented } \\
\text { with } 50 \mathrm{~g} / \mathrm{day} \text { of probiotic or }\end{array}$ & $\begin{array}{l}\text { BMI, arterial blood pressure, } \\
\text { and the risk of metabolic }\end{array}$ \\
& $\begin{array}{l}\text { control cheese } \\
\text { syndrome in obese patients } \\
\text { with hypertension }\end{array}$
\end{tabular}

\begin{tabular}{|c|c|c|c|}
\hline $\begin{array}{l}\text { Lactobacillus gasseri SBT2055 } \\
\text { (LG2055) included in fermented } \\
\text { milk }\end{array}$ & $\begin{array}{l}\text { A multicenter, double-blind, } \\
\text { randomized, placebo- } \\
\text { controlled intervention trial in } \\
\text { which } 87 \text { subjects (BMI } \\
\text { between } 24.2 \text { and } 30.7 \mathrm{~kg} / \mathrm{m}^{2} \\
\text { and abdominal visceral fat area } \\
\text { of } 81.2-178.5 \mathrm{~cm}^{2} \text { ) were } \\
\text { randomly assigned to consume } \\
200 \mathrm{~g} / \text { day of fermented milk } \\
\text { with or without LG2055 }\end{array}$ & $\begin{array}{l}\text { The probiotic LG2055 showed } \\
\text { lowering effects on abdominal } \\
\text { adiposity, body weight and } \\
\text { other measures, suggesting its } \\
\text { beneficial influence on } \\
\text { metabolic disorders }\end{array}$ & [69] \\
\hline $\begin{array}{l}\text { Lactobacillus amylovorus and } \\
\text { Lactobacillus fermentum } \\
\text { microencapsulated in yogurt ( } 1.39 \text {. } \\
10^{9} \mathrm{CFU} / \text { yogurt) }\end{array}$ & $\begin{array}{l}\text { A placebo controlled, double- } \\
\text { blind cross-over clinical } \\
\text { investigation with } 28 \text { healthy, } \\
\text { but overweight individuals } \\
(\mathrm{BMI} \text { between } 25 \text { and } 32 \\
\mathrm{kg} / \mathrm{m}^{2} \text { ) }\end{array}$ & $\begin{array}{l}\text { Probiotic consumption altered } \\
\text { intestinal microflora in a } \\
\text { manner that was associated } \\
\text { with reduced total body } \\
\text { adiposity, an important } \\
\text { anthropometric indicator of } \\
\text { obesity }\end{array}$ & [70] \\
\hline
\end{tabular}

\section{Case study: functional foods development from lulo fruit with potential effect against metabolic syndrome}

The lulo fruit (Solanum quitoense Lam.), also known as "naranjilla", is an important native Andean crop. Grown and consumed mainly in Colombia, Ecuador and Central America, the plant produces a spherical, 3 to $8 \mathrm{~cm}$ diameter fruit with orange skin (epicarp) covered by short, stiff and thorny hairs or spines. The internal structure of the fruit is similar to that of the tomato fruit: a very juicy, acid and translucent yellowgreen pulp (mesocarp and endocarp) that is located in four compartments separated by membranous partitions [71]. In Colombia, lulo is an economically important crop which, in 2015, was grown in a total area of 10,623 ha, with a total yield of 82,354 tons and an average yield of 9.6 tons/ha [72]. Although the principal market of this crop is in the producing countries themselves, it has gained interest in recent years in national and international markets due to its organoleptic properties and its nutritional value. In fact, lulo has an intense and refreshing taste and is rich in proteins, vitamin $C$, fiber, and antioxidant compounds, such as all-trans- $\beta$ carotene, lutein and zeaxanthin, chlorogenic acids and flavonol glycosides 
[73-76], in addition to iron, calcium, phosphorus and some precursors of vitamin A [77] (table 6 [78]).

In particular, fruit carotenoids present in lulo fruit have been associated to the prevention of several illnesses, including hypertension, obesity and cardiovascular diseases [79-81]. Also, the potential of lulo as an antihypertensive agent is related to its content in N1, N4, N8-tris (dihydrocaffeoyl) spermidine and N1, N8-bis (dihydrocaffeoyl) spermidine (actually bioactive amines), which are bitter active compounds with inhibitory activity against the angiotensin-converting enzyme (ACE-1) that indirectly increases the blood pressure by causing blood vessels to constrict [35]. In turn, when evaluating the antihypertensive activity of some compounds of the lulo fruit by means of chemical computation techniques, the researchers of the Natural Additives of Aroma and Color group from the Chemistry Department of the Universidad Nacional de Colombia found that this was between 10 and 20 times higher than that of the drugs traditionally used to treat hypertension.

Table 6. Nutrition facts of lulo fruit.

\begin{tabular}{|c|c|c|c|c|c|}
\hline \multicolumn{2}{|c|}{ Proximates } & \multicolumn{2}{|c|}{ Minerals } & \multicolumn{2}{|l|}{ Vitamins } \\
\hline Carb & $5.9 \mathrm{~g}$ & $\mathrm{Ca}$ & $8 \mathrm{mg}$ & Folate & $3 \mu \mathrm{g}$ \\
\hline Fiber & $1.1 \mathrm{~g}$ & $\mathrm{Mg}$ & $11 \mathrm{mg}$ & Vit B3 & $1.45 \mathrm{mg}$ \\
\hline Protein & $0.44 \mathrm{~g}$ & $\mathrm{P}$ & $12 \mathrm{mg}$ & Vit B5 & $0.22 \mathrm{mg}$ \\
\hline Sugars & $3.74 \mathrm{~g}$ & $\mathrm{~K}$ & $200 \mathrm{mg}$ & Vit B1 & $0.05 \mathrm{mg}$ \\
\hline Fat & $0.22 \mathrm{~g}$ & $\mathrm{Na}$ & $4 \mathrm{mg}$ & Vit B6 & $0.11 \mathrm{mg}$ \\
\hline Water & $93.05 \mathrm{~g}$ & $\mathrm{Cu}$ & $0.03 \mathrm{mg}$ & Vit C & $3.2 \mathrm{mg}$ \\
\hline \multirow[t]{10}{*}{ Energy } & $25 \mathrm{cal}$ & $\mathrm{Fe}$ & $0.35 \mathrm{mg}$ & $\alpha$-carotene & $4 \mu \mathrm{m}$ \\
\hline & & $\mathrm{Mn}$ & $0.07 \mathrm{mg}$ & $\beta$-carotene & $333 \mu \mathrm{m}$ \\
\hline & & $\mathrm{Se}$ & $0.4 \mu \mathrm{g}$ & $\beta$-cryptoxanthin & $10 \mu \mathrm{m}$ \\
\hline & & $\mathrm{Zn}$ & $0.1 \mathrm{mg}$ & Lutein \& zeaxanthin & $299 \mu \mathrm{m}$ \\
\hline & & & & $\gamma$-tocopherol & $0.2 \mathrm{mg}$ \\
\hline & & & & $\alpha$-tocotrienol & $0.01 \mathrm{mg}$ \\
\hline & & & & $\gamma$-tocotrienol & $0.01 \mathrm{mg}$ \\
\hline & & & & Vit A & $28 \mu \mathrm{m}$ \\
\hline & & & & Vit E & $0.75 \mathrm{mg}$ \\
\hline & & & & Vit K & $14.6 \mu \mathrm{m}$ \\
\hline
\end{tabular}

Values expressed for $100 \mathrm{~g}$ of fresh fruit

Based on the considerations made above, the lulo fruit comes to be a promising alternative with regards to the prevention and relief of hypertension-related diseases. However, being a highly perishable fruit, technological transformation processes are indispensable to take advantage of its beneficial properties by as many consumers as possible. According to this, the group of Functional Foods of the University Institute 
of Food Engineering for Development of the Polytechnic University of Valencia (Spain), in conjunction with the group of Biodiversity Evaluation and Use of the Technological University of Chocó (Colombia), is working on the development of new functional foods from lulo fruit (Solanum quitoense Lam). On the one hand, a stable lulo juice with improved antioxidant properties has been obtained by means of the application of moderate high homogenization pressures (from 50 to $150 \mathrm{MPa}$ ) instead of traditional thermal pasteurization. The same juice has proved to be a suitable impregnation liquid for the enrichment of other fruits with a porous structure, such as Granny Smith apples. The lulo fruit itself was found to have a high impregnation capacity, which implies susceptibility to be enriched with different bioactive compounds.

Finally, after fermentation with Lactobacillus reuteri, selected for being one of the strains with proven effect against the metabolic syndrome, the number of viable counts in lulo juice resulted high enough to claim that it also may exert a probiotic effect. Most relevant results in relation to these advances are shown next.

\subsection{Enhancing antioxidant properties of lulo juice by means of moderate high-pressure homogenization}

This section shows the effect that homogenization pressures in the range of 50-150 MPa have on main physicochemical properties, including the total content of phenols and flavonoids and the antioxidant activity measured by both DPPH and ABTS methods. To obtain the juice, washed and without peduncle lulo fruits were crushed for $10 \mathrm{~min}$ in a blender (Phillips Avance Collection Standmixer, 800W 2L). The liquefied product was then filtered with a stainless steel sieve of $500 \mu \mathrm{m}$ nominal aperture. When necessary, the juice was homogenized at 50, 100 or $150 \mathrm{MPa}$ in a laboratory scale high-pressure homogenizer (Panda Plus 2000, GEA-Niro Soavi, Parma, Italy).

As it can be observed in table 7, neither the soluble solids content nor the $\mathrm{pH}$ or the density of the lulo juices were significantly affected by homogenization pressure. On the contrary, the consistency index (K) increased significantly after the homogenization step, which is directly related to particle size reduction. As regards the average size of particles, 
it was maximum in the non-homogenized juice $(251 \pm 5 \mu \mathrm{m})$ and minimum in the juice homogenized at $150 \mathrm{MPa}(57.94 \pm 0,14 \mu \mathrm{m})$. Therefore, homogenization increased the amount of solids in suspension and, consequently, the stability of the cloud.

Table 7. Effect of homogenization pressure on $\mathrm{pH}$, soluble solids content (Brix), apparent density $(\rho)$ and rheological properties of lulo juice.

\begin{tabular}{cccccc}
\hline $\begin{array}{c}\text { Homogenization } \\
\text { Pressure }\end{array}$ & Brix & pH & $\begin{array}{c}\rho \\
\left(\mathrm{g} / \mathbf{c m}^{3}\right)\end{array}$ & $K\left(\mathrm{~Pa} \cdot \mathbf{s}^{\mathrm{n}}\right)$ & $\mathbf{n}$ \\
\hline $0 \mathrm{MPa}$ & $6.57 \pm 0.12^{\mathrm{a}}$ & $3.13 \pm 0.02^{\mathrm{a}}$ & $1.04 \pm 0.02^{\mathrm{a}}$ & $0.39 \pm 0.12^{\mathrm{a}}$ & $0.44 \pm 0.06^{\mathrm{b}}$ \\
\hline $50 \mathrm{MPa}$ & $6.4 \pm 0.4^{\mathrm{a}}$ & $3.12 \pm 0.02^{\mathrm{a}}$ & $1.06 \pm 0.04^{\mathrm{a}}$ & $0.9 \pm 0.4^{\mathrm{b}}$ & $0.37 \pm 0.04^{\mathrm{a}}$ \\
\hline $100 \mathrm{MPa}$ & $6.33 \pm 0.15^{\mathrm{a}}$ & $3.18 \pm 0.03^{\mathrm{a}}$ & $1.07 \pm 0.02^{\mathrm{a}}$ & $0.79 \pm 0.02^{\mathrm{ab}}$ & $0.37 \pm 0.03^{\mathrm{a}}$ \\
\hline $150 \mathrm{MPa}$ & $6.4 \pm 0.4^{\mathrm{a}}$ & $3.15 \pm 0.02^{\mathrm{a}}$ & $1.09 \pm 0.02^{\mathrm{a}}$ & $1.3 \pm 0.5^{\mathrm{b}}$ & $0.34 \pm 0.04^{\mathrm{a}}$
\end{tabular}

abc... different superscripts in the same column indicate statistically significant differences $(p<0.05)$

As regards the antioxidant properties of lulo juice, the fruit's own transformation into juice significantly reduced both total phenols and total flavonoids content, which were probably separated from the juice together with the bagasse during the filtration step. However, the concentration of such compounds increased slightly (from $1.03 \pm 0.16$ to $1.28 \pm 0.07 \mathrm{mg} \mathrm{GAE} / \mathrm{g}$ for phenols and from $0.35 \pm 0.24$ to $0.570 \pm 0.011$ mg QE/g for flavonoids) after juice homogenization at $150 \mathrm{MPa}$ and the subsequent reduction in the average particle size. Similar trends were observed when analyzing the total antioxidant activity by both the ABTS and the DPPH methods and when quantifying spermidine by HPLC analysis. For the latter compound, concentration increased from $1.86 \mathrm{ppm}$ in non-homogenized lulo juice to $2.04 \mathrm{ppm}$ in lulo juice homogenized at $150 \mathrm{MPa}$.

Regarding the ability of the homogenized lulo juice treated at 150 MPa to impregnate Granny Smith apples sliced, it was found to be similar to that of an isotonic sucrose solution. In this way, the bioactive compounds present in lulo juice may become part of the vacuum impregnated fruit composition. To be more precise, around $0.22 \mathrm{~m}^{3}$ of lulo juice homogenized at $150 \mathrm{MPa}$ could be incorporated to every $\mathrm{m}^{3}$ of fresh apple. 


\subsection{Lulo fruit as a food matrix for vacuum impregnation and food properties improvement}

In this section, impregnation properties of lulo fruit are discussed. Vacuum impregnation being a matrix engineering technique that allows to introduce desirable compounds into the porous structure of foods by applying a pressure gradient [14]. Among the impregnation parameters, it stands out the volume of the external liquid that can be incorporated into the cellular tissue in a controlled way (i.e., $X$, in $\mathrm{m}^{3} / \mathrm{m}^{3}$ ), which informs about the feasibility of incorporating physiologically active compounds into its porous structure for the formulation of new products with enhanced functional properties. Hence, unpeeled lulo fruit was cut into 5 $\mathrm{mm}$ thick slices and immersed in an isotonic sucrose solution $\left(\mathrm{a}_{\mathrm{w}}=0.994 \pm\right.$ 0.003). Vacuum impregnation was carried out in a pilot plant scale equipment located at the University Institute of Food Engineering for Development of the Universitat Politècnica de València (Spain). This equipment consists of a stainless steel vacuum chamber connected to a liquid ring pump (SIHI model LOHE-25007).

The vessel containing the impregnating solution was placed into the vacuum chamber and the lulo samples were immersed in the liquid by means of a pneumatic arm operated by a compressor (COMBA, 1,5 HP de $25 \mathrm{~L})$. The working conditions were set at $50 \mathrm{mbar}$ for $10 \mathrm{~min}$ and atmospheric pressure for 10 min more. In each trial, the weight change of the samples was recorded according to the procedure described by [82], thus allowing to calculate the characteristic impregnation parameters of the lulo fruit.

As it is shown in table 8, the different batches analysed behaved in a similar way during the vacuum impregnation step. Positive values of parameters $X_{1}$ (between 1 and 5\%) and $X$ (between 8.6 and 16\%) indicate that the impregnating liquid entered the porous structure after both the vacuum and the atmospheric step. Likewise, positive values of parameters $\gamma_{1}$ (between 3.9 and $7.1 \%$ ) and $\gamma$ (between 2.9 and 6.6\%) indicate a volumetric expansion of the lulo matrix after both the vacuum and the atmospheric step. Compared to other fruits and vegetables [83], the volume fraction of fresh lulo that was filled with the impregnating solution 
at the end of the process $\left(X\right.$, in $\left.\mathrm{m}^{3} / 100 \mathrm{~m}^{3}\right)$ was significantly lower than that of Granny Smith apple (21.0 \pm 0.9$)$ or Soraya aubergine $(64 \pm 2)$, but considerably higher than that of Chandler strawberry (6.4 \pm 0.3$)$, Hayward kiwifruit $(0.7 \pm 0.5)$ or Bulida apricot $(2.2 \pm 0.2)$. Despite such differences, the lulo matrix can be considered as suitable to be enriched with other active compounds by means of the vacuum impregnation technique.

Table 8. Vacuum impregnation response of lulo fruit slices ( $5 \mathrm{~mm}$ thick).

\begin{tabular}{cccccc}
\hline BATCH & $\mathrm{x}_{1}$ & $\gamma_{1}$ & $\mathrm{x}$ & $\gamma$ & $\varepsilon_{\mathrm{e}}$ \\
\hline $\mathbf{1}$ & $5 \pm 7^{\mathrm{a}}$ & $5 \pm 4^{\mathrm{a}}$ & $8.8 \pm 1.6^{\mathrm{a}}$ & $3 \pm 3^{\mathrm{a}}$ & $6 \pm 4^{\mathrm{a}}$ \\
\hline $\mathbf{2}$ & $2.1 \pm 1.8^{\mathrm{a}}$ & $6 \pm 5^{\mathrm{a}}$ & $10 \pm 3^{\mathrm{a}}$ & $5 \pm 4^{\mathrm{a}}$ & $6 \pm 5^{\mathrm{a}}$ \\
\hline $\mathbf{3}$ & $2 \pm 4^{\mathrm{a}}$ & $5 \pm 2^{\mathrm{a}}$ & $11 \pm 2^{\mathrm{ab}}$ & $3.7 \pm 0.9^{\mathrm{a}}$ & $8 \pm 2^{\mathrm{a}}$ \\
\hline $\mathbf{4}$ & $1 \pm 1.4^{\mathrm{a}}$ & $3.9 \pm 0.9^{\mathrm{a}}$ & $16 \pm 6^{\mathrm{b}}$ & $6.6 \pm 1.0^{\mathrm{a}}$ & $9 \pm 6^{\mathrm{a}}$ \\
\hline $\mathbf{5}$ & $2.5 \pm 1.3^{\mathrm{a}}$ & $7.1 \pm 1.0^{\mathrm{a}}$ & $8.6 \pm 0.9^{\mathrm{a}}$ & $2.9 \pm 0.8^{\mathrm{a}}$ & $6.3 \pm 1.2^{\mathrm{a}}$ \\
\hline
\end{tabular}

abc... different superscripts in the same column indicate statistically significant differences $(p \leq 0.05)$.

$\mathrm{X} 1$ and $\mathrm{X}$ stand for the volume fraction of fresh sample impregnated at the end of the vacuum step and at the end of the atmospheric step, respectively; $\gamma 1$ and $\gamma$ stand for the relative volume deformation of fresh sample at the end of the vacuum step and at the end of the atmospheric step, respectively; $\varepsilon_{\mathrm{e}}$ stand for the effective porosity.

\subsection{Probiotic foods development from lulo fruit}

The growing number of consumers with lactose intolerance, high cholesterol levels and/or following vegetarian or vegan diets has encouraged the recent use of fruits and vegetables as probiotic carriers in the development of new functional foods. Fruit and vegetable juices are especially suitable for the growing of probiotic microorganisms since they inherently contain beneficial nutrients and have taste profiles that are pleasing to all the age groups [84]. In addition, due to their fast passage through the digestive tract, the viability of probiotic cells in the juices is hardly affected by the harsh acidic environment of stomach [85]. However, these food matrices do not always fulfil the $\mathrm{pH}$, or the essential amino acids and vitamins required for the optimum growth of most $L A B$ with proven probiotic effect. This section evaluates the possibility of using the non-homogenized lulo juice as a medium for the growth of Lactobacillus reuteri CECT 925T. For this purpose, the lulo juice obtained by the procedure described above was pasteurized at $75{ }^{\circ} \mathrm{C}$ for $2.5 \mathrm{~min}$ before being inoculated with $4 \mathrm{~mL} / \mathrm{L}$ of MRS broth containing the active microorganism in a concentration of $10^{8} \mathrm{CFU} / \mathrm{mL}$. After 24 hours of incubation at $37{ }^{\circ} \mathrm{C}$, viable counts in the juice were of the order of $10^{6}$ 
$\mathrm{CFU} / \mathrm{mL}$. Although this value was high enough to make an EU-based health claim [86], it was significantly lower to that obtained in mandarin juice inoculated with either Lactobacillus salivarius spp. salivarius CECT 4063 or Lactobacillus acidophilus CECT 903 [87].

In a further step, the lulo juice containing the probiotic was employed as impregnating liquid for the vacuum impregnation of Granny Smith apple slices ( $5 \mathrm{~mm}$ thick). In this way, the probiotic was introduced into a solid matrix without disturbing its organized cellular structure. However, since only $20 \%$ of the initial volume of the apple is filled with the impregnation liquid during the vacuum impregnation step, the probiotic content in the impregnated apple was not greater than $10^{5} \mathrm{CFU} / \mathrm{g}$. Subsequent lyophilisation of the vacuum impregnated apples did not increase the Lactobacillus reuteri content as expected by water removal and subsequent weight loss, it being lower than $10^{6} \mathrm{CFU} / \mathrm{g}$ in the liophylized sample. Probiotic counts in both the lulo juice and the impregnated apple snack could be improved by adding certain ingredients (e.g. prebiotics, cryprotectants, soygerm powder, yeast extract, etc.) and/or applying specific processing technologies that can improve microorganism survival such as microencapsulation or sub lethal homogenization. In any case, it should be interesting to evaluate through both in vivo and in vitro studies the antihypertensive activity of Lactobacillus reuteri in the products designed, since it could be enhanced due to a synergistic effect with the spermidine from the lulo juice.

\section{Market and consumer trends toward functional foods}

Revolution in living standard, eating habits, and increased health awareness has shifted consumer's acceptance toward nutritious, healthy, and disease-preventive food with wider health benefits. Consumer is becoming more and more conscious about the role of food in life extension, well-being, and prevention of chronic diseases [87].

Specific consumer characteristics, such as demographic background or personal motivation to participate in pro-health activities, play a remarkable role in functional food acceptance and consumption. Some sociodemographic characteristics such as gender, education, and 
age are the most important factors related to the acceptance of functional food. In addition, apart from health benefits, the carrier and the origin of functional components play an important role in making the decision to purchase functional products, consumers being more likely to purchase those functional components found naturally in foods. Other factors, such as organoleptic attributes, convenience, or label information, are found to be essential for consumer's acceptance. In his study, Kraus [88] concludes that consumers are not willing to sacrifice taste and general pleasure of eating and also states that naturalness of a product is very important.

Particularly for probiotics, a major challenge for these products is product acceptability by consumers with regard to sensory criteria. Traditionally, health benefits of probiotics were based in the consumption of fermented dairy products; however, lactose intolerance, cholesterol content, and allergic milk proteins have limited the growth of dairy probiotics. Besides, the increase in vegetarian consumers in both developed and developing countries has also contributed to a growing demand for plant-based probiotic products [87]. According to Panghal et al. [요], fruits are healthy and refreshing and have good taste and flavor profile and can be suitable for probiotics. They are an ideal medium to develop functional foods and have more nutritional values due to the presence of various phytochemicals, antioxidants, no cholesterol, vitamins, mineral content, and dietary fibers. Besides, economic reasons for the developing countries also require the search for an alternative to dairy products with good nutrients along with health-promoting factors, e.g., fruits, vegetables, cereal, legume, etc., and products which lack cholesterol content but are rich in protein, starches, minerals, fiber, vitamins, and antioxidants.

Nowadays an increasing trend in the Western society is consumer interest and focus toward natural and organic products, where the use of synthetic additives is limited. It has been suggested that natural ingredients with strong antioxidant activity could be used to design novel functional beverages. An increased interest relies upon the fortification with polyphenols due to their beneficial role against cardiovascular diseases, type 2 diabetes, and obesity, among other conditions. The combination of prebiotics, and also phenols with probiotic 
microorganisms, represents an innovative biotechnology to enlarge the functional food market and especially beverages [90].

According to Grand View Research [91], the global functional food market was higher than 129 billion dollars (US) in 2015, and it is expected to increase up to 250 billion in 2024. Growing consciousness among consumers on their health and proper diet, together with the prospect of reducing or even eliminating nutrition-related diseases, is responsible of this market trend. Society is becoming more and more conscious on the impact that changing dietary patterns may have in the incidence of type 2 diabetes, coronary heart disease, cancer, periodontal disease, and obesity. In this regard, functional foods are believed to play an outstanding role. In addition, increasing healthcare cost, along with the desire of improving later years among the geriatric population, has driven the growth of the functional food industry worldwide.

The global functional food market includes that of carotenoids, dietary fibers, fatty acids, minerals, prebiotics and probiotics, vitamins, minerals, phytochemicals, enzymes, and antioxidants in general. Market revenue of all these products separately is also expected to increase in the coming years. For example, dietary fibers, which are considered to prevent obesity and diabetes, are expected to grow by $8.4 \%$ in the next 8 years. Other phytochemicals, such as flavonoids, held a share of over $30 \%$ in terms of market value. Although these have been commonly consumed in their natural form, consumer's habits have led to their use in the form of functional food products which are aimed at preventing diet-related chronic diseases including those related to the metabolic syndrome. North America accounts for the largest market in flavonoids, the Asia Pacific demand was over 110 million US Dollars in 2015, and Europe is expected to grow, although at a slower pace. In any case, prevalence of diabetes, obesity, and chronic diseases is likely to propel demand for these nutritional foods and beverages in Europe.

With regard to probiotics, there is also a growing concern on awareness in their functional health benefits against different conditions, including those related to the metabolic syndrome such as obesity or type 2 diabetes [ㄹ] . The global probiotic market was thought to be worth 35.5 
billion dollars in 2016, with predictions of this increasing up to 65 billion dollars by 2024 [93]. As reported by Lumina intelligence [92], a survey of Ganeden on consumers concluded that almost $80 \%$ of consumers preferred to consume probiotics in food and beverage products than in supplements. This is of special value taking into account that consumer preference is a key currency for measuring product success and predicting upcoming tendencies. North America demand for probiotics is expected to increase by $7.9 \%$ from 2016 to 2025, whereas the European market will grow at a pace of $7.3 \%$. As for Asia Pacific countries, the probiotics industry is also expected to increase significantly.

Probiotics have achieved a prominent position in the global food market. Among the countries that have shown growth in the probiotic market, Europe represents the largest and fastest growing market, followed by Japan. Currently, there is a wide range of probiotic products offered by companies such as BioGaia Biologics $A B$, Christian Hansen $A / S$, ConAgra Functional Foods, Danisco, Groupe Danone, or Lifeway [87].

\section{Conclusions}

The huge increase in obesity and consequently of physiological disorders associated with this, have led to a massive increase in research work conducted in this area over the past ten years. The relationship between diet and the incidence of metabolic syndrome is clearly contrasted. Although this relationship is tremendously complex and it is hardly affected by other variables related to lifestyle, specific works establish phytochemicals and probiotics as two of the active components present in food, which have the greatest effect on prevention and in the reduction of symptoms associated with metabolic syndrome.

Currently, the technological development achieved by the food industry allows both the design and development of specific foods that include active components in their composition, as well as the application of specific techniques that increase the functional value of natural foods. The use of these advances in the right direction can be decisive in the solution of health problems related to obesity. Specifically, the application of moderate homogenization pressures, or food formulation techniques such as vacuum impregnation, are presented as possibilities to develop 
liquid and / or solid foods that combine the presence of phytochemicals and probiotics with demonstrated effectiveness against obesity in natural foods such as lulo fruit.

\section{Acknowledgments}

This research was funded in part by a PhD Research Fellowship from the Technological University of Chocó (Colombia). Authors specially thank Alicia Ríos Hurtado for her support, to the Government of the Department of Chocó and to the Research Group on Assessment and Use of Biodiversity (Chocó, Colombia).

\section{References}

1. World Health Organization. 10 facts on obesity [Internet]. 2017. Available from: https://www.who.int/features/factfiles/obesity/en/ [Accessed: 2018-12-15]

2. Park SY, Seong KS, Lim SD. Anti-obesity Effect of Yogurt Fermented by Lactobacillus plantarum Q180 in Diet-induced Obese Rats. Korean Journal for Food Science of Animal Resources, 2016;36(1):77-83.

3. Kaur J. A comprehensive review on metabolic syndrome. Cardiology Research and Practice, 2014:1-21.

4. Esser N, Legrand-Poels S, Piette J, Scheen AJ, Paquot N. Inflammation as a link between obesity, metabolic syndrome and type 2 diabetes. Diabetes Research and Clinical Practice, 2014;105(2):141-150.

5. Monteiro R, Azevedo I. Chronic Inflammation in Obesity and the Metabolic Syndrome. Mediators of Inflammation, 2010: 10 pages.

6. Faloia E, Michetti G, De Robertis M, Luconi MP, Furlani G, Boscaro M. Inflammation as a Link between Obesity and Metabolic Syndrome. Journal of Nutrition and Metabolism, 2012; 7.

7. Liang Y, Hou Y, Niu H, Lu M, Xue L, Sun Q. Correlation of high-sensitivity C-reactive protein and carotid plaques with coronary artery disease in elderly patients. Experimental and Therapeutic Medicine, 2015;10(1):275-278.

8. Flannagan KS, Ramírez-Zea M, Roman AV, Das AK, Villamor E. Adipose tissue polyunsaturated fatty acids and metabolic syndrome among adult parents and their children. Nutrition, Metabolism and Cardiovascular Diseases, 2018;28(12):1237-1244.

9. Retondario A, Fernandes R, Rockenbach G, Alves M de A, Bricarello LP, Trindade EBS de $M$, Guedes de Vasconcelos $F$ de A. Selenium intake and metabolic syndrome: A systematic review. Clinical Nutrition.

10. Guarnizo-Poma M, Urrunaga-Pastor D, Montero-Suyo C, Lazaro-Alcantara H, Paico-Palacios S, Pantoja-Torres B, Benites-Zapata VA. Association between serum vitamin B12 levels and metabolic syndrome in a euthyroid population. Diabetes \& Metabolic Syndrome: Clinical Research \& Reviews, 2018;12(6): 943-948.

11. Urrunaga-Pastor D, Guarnizo-Poma M, Macollunco-Flores P, Lazaro-Alcantara $H$, Paico-Palacios S, Pantoja-Torres B, Benites-Zapata VA. Association between vitamin $D$ deficiency and insulin resistance markers in euthyroid non-diabetic individuals. Diabetes \& Metabolic Syndrome: Clinical Research \& Reviews, 2019;13(1):258-263. 
12. Ford ES, Mokdad AH, Giles WH, Brown DW. The metabolic syndrome and antioxidant concentrations findings from the Third National Health and Nutrition Examination Survey. Diabetes, 2003;52(9):2346-2352. Available at: diabetes.diabetesjournals.org/content/diabetes/52/9/2346.full.pdf

13. Cardona-Velásquez S, Guzmán-Vivares L, Cardona-Arias JA. Systematization of clinical trials related to treatment of metabolic syndrome, 1980-2015. Endocrinología, Diabetes y Nutrición (English ed.), 2017;64(2):82-91.

14. Betoret E, Betoret N, Vidal D, Fito P. Functional foods development: Trends and technologies. Trends in Food Science \& Technology, 2011;22(9):498-508.

15. Chen JP, Chen GC, Wang XP, Qin L, Bai Y. Dietary Fiber and Metabolic Syndrome: A Meta-Analysis and Review of Related Mechanisms. Nutrients, 2018;10(1):17.

16. Morrison DJ, Preston T. Formation of short chain fatty acids by the gut microbiota and their impact on human metabolism. Gut Microbes. 2016;7(3):189-200.

17. Tassinari S, Azuero A, Arreaza D, Rueda-Rodríguez MC, Castañeda-Cardona C, Rosselli D. Suplementos nutricionales como modificadores del riesgo cardiovascular en componentes del síndrome metabólico en adultos. Revista Colombiana de Cardiología, 2017;24(3):277-285.

18. Traber MG, Buettner GR, Bruno RS. The relationship between vitamin C status, the GUT-liver axis, and metabolic syndrome. Redox Biology. In Press, Accepted Manuscript.

19. Iwaniak A, Darewicz M, and Minkiewicz P. Peptides derived from foods as supportive diet components in the prevention of the metabolic syndrome. Comprehensive Reviews in Food Science and Food Safety, 2018;14:63-81.

20. Khan MI, Anjum FM, Sohaib M, Sameen A. Tackling metabolic syndrome by functional foods. Reviews in Endocrine \& Metabolic Disorders, 2013;14(3):287297.

21. Zemel MB. Role of calcium and dairy products in energy partitioning and weight management. The American Journal of Clinical Nutrition, 2004;79(5):907S-912S.

22. Shi H, Halvorsen YD, Ellis PN, Wilkinson WO, Zemel MB. Role of intracellular calcium in human adipocyte differentiation. Physiological Genomics, 2000;3(2):75-82.

23. Zheng $\mathrm{H}$, Lenard NR, Shin AC, Berthoud HR. Appetite control and energy balance regulation in the modern world: reward-driven brain overrides repletion signals. International Journal of Obesity, 2009;33(S2):S8-S13.

24. Kobori M. Dietary Quercetin and other Polyphenols: Attenuation of Obesity. In: Watson RR, Preedy VR, Zibadi S, editors. Polyphenols in Human Health and Disease, vol. 1. Academic Press; 2014. p. 163-175.

25. Pastor-Villaescusa B, Sánchez-Rodriguez E, Rangel-Huerta OD. Polyphenols in Obesity and Metabolic Syndrome. In: Martí del Moral A, Aguilera-García CM, editors. Obesity: oxidative stress and dietary antioxidants. Academic Press; 2018. p. 213-239.

26. Sharma H, Kumar P, Deshmukh RR, Bishayee A, Kumar S. Pentacyclic triterpenes: New tools to fight metabolic syndrome. Phytomedicine, 2018;50:166-177. DOI: 10.1016/j.phymed.2018.09.011

27. Wang S, Moustaid-Moussa N, Chen L, Mo H, Shastri A, Su R, Shen CL. Novel insights of dietary polyphenols and obesity. Journal of Nutritional Biochemistry, 2014;25(1):1-18.

28. Williams DJ, Edwards D, Hamernig I, Jian L, James AP, Johnson SK, Tapsell LC. Vegetables containing phytochemicals with potential anti-obesity properties: A review. Food Research International, 2013;52(1):323-333. 
29. Mallappa RH, Rokana N, Duary RK, Panwar H, Batish VK, Grover S. Management of metabolic syndrome through probiotic and prebiotic interventions. Indian Journal of Endocrinology and Metabolism, 2012;16(1):20-27.

30. Arts IC, Hollman PC. Polyphenols and disease risk in epidemiologic studies. The American Journal of Clinical Nutrition, 2005;81(1):317S-325S.

31. Holubková A, Penesová A, Šturdík E, Mošovská S, Mikušová L. Phytochemicals with potential effects in metabolic syndrome prevention and therapy. Acta Chimica Slovaca, 2012;5(2):186-199.

32. Richard AJ, Amini-Vaughan Z, Ribnicky DM, Stephens JM. Naringenin inhibits adipogenesis and reduces insulin sensitivity and adiponectin expression in adipocytes. Evidence-Based Complementary and Alternative Medicine, 2013.

33. Liang J, Halipu Y, Hu F, Yakeya B, Chen W, Zhang H, Kang X. Naringenin protects keratinocytes from oxidative stress injury via inhibition of the NOD2-mediated NFKB pathway in pemphigus vulgaris. Biomedicine and Pharmacotherapy, 2017;92:796-801.

34. Landa P, Kokoska L, Pribylova M, Vanek T, Marsik P. In vitro anti-inflammatory activity of carvacrol: Inhibitory effect on COX-2 catalyzed prostaglandin E2 biosynthesis. Archives of Pharmacal Research, 2009;32(1):75-78.

35. Forero DP, Masatani C, Fujimoto Y, Coy-Barrera E, Peterson D, Osorio C. 2016. Spermidine Derivatives in Lulo (Solanum quitoense Lam.) Fruit: Sensory (Taste) versus Biofunctional (ACE-Inhibition) Properties. Journal of Agriculture and Food Chemistry, 2016;64(26):5375-5383.

36. Hsu CL, Yen GC. Induction of cell apoptosis in 3T3-L1 pre-adipocytes by flavonoids is associated with their antioxidant activity. Molecular Nutrition and Food Research, 2006;50(11):1072-1079.

37. González-Castejón M, Rodriguez-Casado A. Dietary phytochemicals and their potential effects on obesity: A review. Pharmacological Research, 2011;64(5): 438455.

38. Yang JY, Della-Fera MA, Nelson-Dooley C, Baile CA. Molecular mechanisms of apoptosis induced by ajoene in 3T3-L1 adipocytes. Obesity, 2006;14(3):388-397.

39. Karim N, Jia Z, Zheng X, Cui S., Chen W. A recent review of citrus flavanone naringenin on metabolic diseases and its potential sources for high yieldproduction. Trends in Food Science and Technology, 2018;79(March): 35-54.

40. Yang M, Jiang ZH, Li CG, Zhu YJ, Li Z, Tang YZ, Ni CL. Apigenin prevents metabolic syndrome in high-fructose diet-fed mice by Keap1-Nrf2 pathway. Biomedicine and Pharmacotherapy, 2018;105:1283-1290.

41. Cho S, Choi Y, Park S, Park T. Carvacrol prevents diet-induced obesity by modulating gene expressions involved in adipogenesis and inflammation in mice fed with high-fat diet. Journal of Nutritional Biochemistry, 2012;23(2):192-201.

42. Son MJ, Rico CW, Nam SH, Kang MY. Effect of Oryzanol and Ferulic Acid on the Glucose Metabolism of Mice Fed with a High-Fat Diet. Journal of Food Science, 2011;76(1):4-7.

43. Pongchaidecha A, Lailerd N, Boonprasert W, Chattipakorn N. Effects of curcuminoid supplement on cardiac autonomic status in high-fat-induced obese rats. Nutrition, 2009;25(7-8):870-878.

44. González-Ortiz M, Méndez-Del Villar M, Martínez-Abundis E, Ramírez-Rodríguez AM. Effect of resveratrol administration on metabolic syndrome, insulin sensitivity, and insulin secretion. Minerva Endocrinologica, 2018;43(3): 229-235.

45. Rezazadeh K, Aliashrafi S, Asghari-Jafarabadi M, Ebrahimi-Mameghani M. Antioxidant response to artichoke leaf extract supplementation in metabolic 
syndrome: A double-blind placebo-controlled randomized clinical trial. Clinical Nutrition, 2018;37(3):790-796.

46. Nishihira J, Sato-Ueshima M, Kitadate K, Wakame K, Fujii H. Amelioration of abdominal obesity by low-molecular-weight polyphenol (Oligonol) from lychee. Journal of Functional Foods, 2009;1(4): 341-348

47. González-Ortiz M, Martínez-Abundis E, Espinel-Bermúdez MC, Pérez-Rubio KG. Effect of pomegranate juice on insulin secretion and sensitivity in patients with obesity. Annals of Nutrition and Metabolism, 2011;58(3): 220-223.

48. Ibero-Baraibar I, Azqueta A, De Cerain AL, Martinez JA, Zulet MA. Assessment of DNA damage using comet assay in middle-aged overweight/obese subjects after following a hypocaloric diet supplemented with cocoa extract. Mutagenesis, 2015;30(1):139-146

49. Amin F, Islam N, Anila N, Gilani AH. Clinical efficacy of the co-administration of Turmeric and Black seeds (Kalongi) in metabolic syndrome-A double blind randomized controlled trial-TAK-MetS trial. Complementary Therapies in Medicine, 2015;23:165-174.

50. FAO/WHO. Working Group Report on Drafting Guidelines for the Evaluation of Probiotics in Food London, Ontario, Canada. 2002.

51. Kobyliak N, Conte C, Cammarota G, Haley AP, Styriak I, Gaspar G, Fusek J, Rodrigo L, Kruzliak P. Probiotics in prevention and treatment of obesity: a critical view. Nutrition \& Metabolism, 2016;13:14.

52. Ghaisas S, Maher J, Kanthasamy A. Gut microbiome in health and disease: linking the microbiome-gut-brain axis and environmental factors in the pathogenesis of systemic and neurodegenerative diseases. Pharmacology \& Therapeutics, 2016;158:52-62.

53. Le Chatelier E, Nielsen T, Qin J, et al. Richness of human gut microbiome correlates with metabolic markers. Nature, 2013;500(7464):541-546.

54. Lehnen TE, Ramos da Silva M, Camacho A, Marcadenti A, Lehnen AM. A review on effects of conjugated linoleic fatty acid (CLA) upon body composition and energetic metabolism. Journal of the International Society of Sports Nutrition, 2015;12: 36.

55. Patterson E, Ryan PM, Cryan JF, Dinan TG, Ross P, Fitzgerald GF, Stanton C. Gut microbiota, obesity and diabetes. Postgraduate Medical Journal, 2016;92(1087):286-300.

56. Wang LC, Pan TM, Tsai TY. Lactic acid bacteria-fermented product of green tea and Houttuynia cordata leaves exerts anti-adipogenic and anti-obesity effects. Journal of Food and Drug Analysis, 2018;26(3):973-984.

57. Zarrati M, Salehi E, Nourijelyani K, Mofid V, Zadeh MJH, Najafi F, Ghaflati Z, Bidad K, Chamari M, Karimi M, Shidfar F. Effects of Probiotic Yogurt on Fat Distribution and Gene Expression of Proinflammatory Factors in Peripheral Blood Mononuclear Cells in Overweight and Obese People with or without Weight-Loss Diet. Journal of the American College of Nutrition, 2014;33(6):1-9.

58. Hsieh FC, Lan CCE, Huang TY, Chen KW, Chai CY, Chen WT, Fang AH, Chen YH, Wu CS. Heat-killed and live Lactobacillus reuteri GMNL-263 exhibit similar effects on improving metabolic functions in high-fat diet-induced obese rats. Food \& Function, 2016;7(5):2374-2388.

59. Lee E, Jung SR, Lee SY, Lee NK, Paik HD, Lim SI. (2018). Lactobacillus plantarum Strain Ln4 Attenuates Diet-Induced Obesity, Insulin Resistance, and Changes in Hepatic mRNA Levels Associated with Glucose and Lipid Metabolism. Nutrients, 2018;10(5):643. 
60. Plovier H, Everard A, Druart C, Depommier C, Van Hul M, Geurts L, Chilloux J, Ottman N, Duparc T, Lichtenstein L, Myridakis A, Delzenne NM, Klievink J, Bhattacharjee A, Van der Ark KC, Aalvink S, Martinez LO, Dumas ME, Maiter D, Loumaye A, Hermans MP, Thissen JP, Belzer C, de Vos WM, Cani PD. A purified membrane protein from Akkermansia muciniphila or the pasteurized bacterium improves metabolism in obese and diabetic mice. Nature Medicine, 2017;23(1):107-113.

61. Chen LH, Chen YH, Cheng KC, Chien TY, Chan CH, Tsao SP, Huang HY. Antiobesity effect of Lactobacillus reuteri 263 associated with energy metabolism remodeling of white adipose tissue in high-energy-diet-fed rats. The Journal of Nutritional Biochemistry, 2018;54:87-94.

62. Balolong MP, Bautista RLS, Encarma NCA, Balolong Jr. EC, Hallare AV, Elegado F. Evaluating the anti-obesity potential of Lactobacillus fermentum 4B1, a probiotic strain isolated from balao-balao, a traditional Philippine fermented food. International Food Research Journal, 2017;24(2):819-824.

63. An HM, Park SY, Lee DK, Kim JR, Cha MK, Lee SW, Lim HT, Kim KJ, Ha NJ. Antiobesity and lipid-lowering effects of Bifidobacterium spp. in high fat diet-induced obese rats. Lipids in Health and Disease, 2011;10:116.

64. Fåk F, Bäckhed F. Lactobacillus reuteri Prevents Diet-Induced Obesity, but not Atherosclerosis, in a Strain Dependent Fashion in Apoe-/- Mice. PloS One, 2012;7(10):e46837.

65. Zhao X, Higashikawa F, Noda M, Kawamura Y, Matoba Y, Kumagai T, Sugiyama M. The Obesity and Fatty Liver Are Reduced by Plant-Derived Pediococcus pentosaceus LP28 in High Fat Diet-Induced Obese Mice. PloS One, 2012;7(2):e30696.

66. Lee SJ, Bose S, Seo JG, Chung WS, Lim CY, Kim H. (2014). The effects of coadministration of probiotics with herbal medicine on obesity, metabolic endotoxemia and dysbiosis: A randomized double-blind controlled clinical trial. Clinical Nutrition, 2014;33(6):973-981.

67. Sanchez M, Darimont C, Drapeau V, Emady-Azar S, Lepage M, Rezzonico E, NgomBru C, Berger B, Philippe L, Ammon-Zuffrey C, Leone P, Chevrier G, St-Amand E, Marette A, Doré J, Tremblay A. Effect of Lactobacillus rhamnosus CGMCC1.3724 supplementation on weight loss and maintenance in obese men and women. British Journal of Nutrition, 2014;111(8):1507-1519.

68. Sharafedtinov KK, Plotnikova OA, Alexeeva R, Sentsova TB, Songisepp E, Stsepetova J, Smidt I, Mikelsaar M. Hypocaloric diet supplemented with probiotic cheese improves body mass index and blood pressure indices of obese hypertensive patients - A randomized double-blind placebo-controlled pilot study. Nutrition Journal, 2013;12:138.

69. Kadooka Y, Sato M, Imaizumi K, Ogawa A, Ikuyama K, Akai Y, Okano M, Kagoshima M, Tsuchida T. Regulation of abdominal adiposity by probiotics (Lactobacillus gasseri SBT2055) in adults with obese tendencies in a randomized controlled trial. European Journal of Clinical Nutrition, 2010;64(6):636-643.

70. Omar JM, Chan YM, Jones ML, Prakash S, Jones PJH. Lactobacillus fermentum and Lactobacillus amylovorus as probiotics alter body adiposity and gut microflora in healthy persons. Journal of Functional Foods, 2013;5(1):116-123.

71. Igual M, Ramires S, Mosquera LH, Martínez-Navarrete N. Optimization of spray drying conditions for lulo (Solanum quitoense L.) pulp. Powder Technology, 2014;256:233-238.

72. Ministerio de Agricultura y Desarrollo Rural de Colombia 2015. Producción nacional por producto. Available online 
http://www.agronet.gov.co/Paginas/ProduccionNacionalProducto.aspx (accessed 24, Jul)

73. Contreras-Calderón J, Calderón-Jaimes L, Guerra-Hernández E, García-Villanova B. Antioxidant capacity, phenolic content and vitamin $C$ in pulp, peel and seed from 24 exotic fruits from Colombia. Food Research International, 2011;44(7):20472053.

74. Gancel AL, Alter P, Dhuique-Mayer C, Ruales J, Vaillant F. 2008. Identifying carotenoids and phenolic compounds in naranjilla (Solanum quitoense Lam. var. puyo hybrid), an Andean fruit. Journal of Agricultural and Food Chemistry, 2008;56(24):11890-11899.

75. Acosta Ó, Pérez AM, Vaillant F. Chemical characterization, antioxidant properties, and volatile constituents of Naranjilla (Solanum quitoense Lam.) cultivated in Costa Rica. Archivos Latinoamericanos de Nutrición, 2009;59(1):88-94. Available online: https://www.ncbi.nlm.nih.gov/pubmed/19480350

76. González-Loaiza DI, Ordóñez-Santos LE, Venegas-Mahecha P, Vásquez-Amariles HD. Cambios en las propiedades fisicoquímicas de frutos de lulo (Solanum quitoense Lam.) cosechados en tres grados de madurez. Revista Acta Agronómica, 2014;63(1):11-17.

77. Vasco C, Ruales J, Kamal-Eldin A. Total phenolic compounds and antioxidant capacities of major fruits from Ecuador. Food Chemistry, 2008;111(4): 816-823.

78. Nutrition facts of lulo fruit. Available online: https://www.traditionaloven.com/foods/details/fruits-juice/naranjilla-lulo-pulpfrozen-unsweeten.htmIMertz C, Gancel AL, Gunata Z, Alter P, Dhuique-Mayer C, Vaillant F, Pérez AM, Ruales J, Brat P. Phenolic compounds, carotenoids and antioxidant activity of three tropical fruits. Journal of Food Composition and Analysis, 2009;22(5):381-387.

79. Van Berleere M, Dauchet L. Fruits, vegetables, and health: evidence from metaanalyses of prospective epidemiological studies. In: Mariotti F, editor. Vegetarian and plant-based diets in health and disease prevention. London: Academic Press; 2017.p. 215- 248.

80. Yahia EM, García-Solís P, Maldonado-Celis ME. Contribution of Fruits and Vegetables to Human Nutrition and Health. In: Yahia EM, editor. Postharvest Physiology and Biochemistry of Fruits and Vegetables. Duxford: Woodhead Publishing; 2019.p. 19-45.

81. Fito P, Andrés A, Chiralt A, Pardo P. Coupling of hydrodinamic mechanism and deformation relaxation phenomena during vaccuum treatments in solid porous food-liquid systems. Journal of Food Engineering, 1996;27(3):229-240.

82. Fito $\mathrm{P}$, Chiralt A, Barat JM, Andrés A, Martínez-Monzó J, Martínez-Navarrete N. Vacuum impregnation for development of new dehydrated products. Journal of Food Engineering, 2001;49(4):297-302.

83. Rivera-Espinoza Y, Gallardo-Navarro Y. Non-dairy probiotic products. Food Microbiology, 2010;27(1):1-11.

84. Vijaya-Kumar B, Vijayendra SVN, Reddy OVS. Trends in dairy and non-dairy probiotic products - a review. Journal of Food Science and Technology, 2015;52(10):6112-6124.

85. Rad AH, Torab R, Mortazavian AM, Mehrabany EV, Mehrabany LV. Can probiotics prevent or improve common cold and influenza? Nutrition, 2013;29(5):805-806.

86. Betoret $\mathrm{E}$, Betoret $\mathrm{N}$, Arilla $\mathrm{A}$, Bennár M, Barrera $\mathrm{C}$, Codoñer $\mathrm{P}$, Fito P. No invasive methodology to produce a probiotic low humid apple snack with probiotic effect against Helicobacter pylori. Journal of Food Engineering, 2012;110(2):289-293. 
87. Panghal A, Janghu S, Virkar K, Gat $Y$, Kumar V, Chhikara N. Potential non-dairy probiotic products-A healthy approach. Food Bioscience. 2018;21:80-89.

88. Kraus A. Factors influencing the decisions to buy and consume functional food. British Food Journal. 2015;117(6):1622-1636.

89. Panghal A, Virkar K, Kumar V, Dhull SB, Gat Y, Chhikara N. Development of probiotic beetroot drink. Current Research in Nutrition and Food Science Journal. 2017;5(3):257-262.

90. Corbo MR, Bevilacvqua A, Petruzzi L, Casanova FP, Sinigaglia M. Functional beverages: The emerging side of functional foods commercial trends, research, and health implications. Comprehensive Reviews in Food Science and Food Safety. 2014;13:1192-1206.

91. Grand View Research. Available from: https://www.grandviewresearch. com/

92. Lumina intelligence.com. Available from: https://www.lumina-intelligence.

com/ 93 Global Market Insights. Available from: https://www.globalinsights.com/ 


\title{
High Homogenization Pressures to Improve Food Quality, Functionality and Sustainability
}

\author{
José Mesa ${ }^{1}$, Leidy Indira Hinestroza-Córdoba ${ }^{1,2}$, Cristina Barrera ${ }^{1}$, Lucía \\ Seguí ${ }^{1}$, Ester Betoret ${ }^{3, *}$ and Noelia Betoret ${ }^{1, *}$ \\ 1 Institute of Food Engineering for Development, Universitat Politècnica de València, CP \\ 46022 València, Spain; jomegu1@etsiamn.upv.es (J.M.); leihicor@doctor.upv.es \\ (L.I.H.); mcbarpu@tal.upv.es (C.B.); lusegil@upvnet.upv.es (L.S.) \\ 2 Grupo de Valoración y Aprovechamiento de la Biodiversidad, Universidad Tecnológica \\ del Chocó. AA.292, Calle 22 No. 18B-10, Quibdó-Chocó, CP 270001 Colombia \\ 3 Instituto de Agroquímica y Tecnología de Alimentos, Consejo Superior de \\ Investigaciones Científicas, 46980 Paterna, Spain \\ * Correspondence: ester_betoret@hotmail.com (E.B.); noebeval@tal.upv.es (N.B.); Tel: \\ +34963877000 (83624) (N.B.)
}

Molecules. 25 (14), 1032

\begin{abstract}
Interest in high homogenization pressure technology has grown over the years. It is a green technology with low energy consumption that does not generate high $\mathrm{CO} 2$ emissions or polluting effluents. Its main food applications derive from its effect on particle size, causing a more homogeneous distribution of fluid elements (particles, globules, droplets, aggregates, etc.) and favoring the release of intracellular components, and from its effect on the structure and configuration of chemical components such as polyphenols and macromolecules such as carbohydrates (fibers) and proteins (also microorganisms and enzymes). The challenges of the 21st century are leading the processed food industry towards the creation of food of high nutritional quality and the use of waste to obtain ingredients with specific properties. For this purpose, soft and nonthermal technologies such as high-pressure homogenization have huge potential. The objective of this work is to review how the need to combine safety, functionality and sustainability in the food industry has conditioned the application of high-pressure homogenization technology in the last decade.
\end{abstract}


Keywords: high homogenization pressure; food functionality; bioactive components; agri-food waste; sustainability.

\section{Introduction}

In the homogenization process, a fluid is forced to pass through a gap, causing energy transformations that directly affect the dissolved, dispersed or emulsified components. The fluid undergoes mechanical (shear, hydrodynamic and cavitation effects) stress and an increase in temperature (thermal effect) of approximately $2-3^{\circ} \mathrm{C}$ for every $10 \mathrm{MPa}$ of homogenization pressure [1]. These affect the fluid structure and properties, and also those of its constituent elements (particles, molecules, globules, droplets, aggregates, granules, etc.). Particle sizes decrease and more homogeneous distribution is achieved, facilitating operations such as mixing and emulsification. The effects are different to those induced by HPP (High Pressure Processing), in which prepacked food is loaded into a pressure vessel and then pressurized at a range of 100$1000 \mathrm{MPa}$, with water as the pressure-transmitting medium [2].

Initially, homogenization was introduced as a manufacturing step in the dairy industry. This operation reduced the size of fat globules, increasing the stability of the emulsion and, thus, the physical and chemical stability of milk. It had a great impact on the quality of dairy products such as condensed milk, curd or ice cream. The applied pressure was less than $30 \mathrm{MPa}$ and it was applied in one or two steps. However, significant technological developments have occurred since then, having an impact on the design and geometry of homogenization valves, and making it possible to work at higher pressures and with very short processing times (a few seconds) [3]. High homogenization pressures were introduced at the beginning of the 2000s as an alternative, nonthermal treatment in the food industry, and applications were extended to industries other than dairy, e.g., to fields such as textile or biotechnologic.

The existence of valves of different geometries has given rise to the design of equipment that is able to work at pressures higher than 400 $\mathrm{MPa}$. Thus, a distinction is made among standard homogenization for pressures between 0 and $50 \mathrm{MPa}$, high pressure homogenization (HPH) for 
pressures between 50 and $300 \mathrm{MPa}$ and ultrahigh pressure homogenization (UHPH) for pressures equal to or greater than $400 \mathrm{MPa}$. Processing efficiency is modulated by applying various pressure ranges or combining a pressure value with a specific number of passes through the equipment [4]. In addition, the possibility of operating continuously for a great diversity of pumpable fluids has made it possible to extend applications to the activation/inactivation of enzymes, reduction of microbial load, mixing, dispersion, emulsification or encapsulation processes, cell breakage processes and the modification of proteins or macromolecules to obtain ingredients or additives with various properties.

Nowadays, concern about food functionality and sustainability is driving research interest in increasing the bioavailability and bioaccessibility of active components and probiotics, and in the extraction of macro- and micro- molecules from food byproducts. The challenges of increasing the nutritional characteristics of food must be combined with a reduction in environmental impact and increased food security. In this context, alternative, soft and nonthermal technologies such as high pressures homogenization have huge potential. The objective of this work is to review how the need to combine safety, functionality and sustainability has conditioned the application of high-pressure homogenization technology in food. Advances and applications in the last decade have been organized according to the main challenges in the food industry.

\section{Evolution and major applications in the last decade}

Publications in peer-reviewed journals show that the main applications of $\mathrm{HPH}$ in food have the following objectives:

- Conservation and safety by decreasing the microbial load and inactivating enzymes. This occurs as a consequence of the thermal effect derived from mechanical stress or from structural changes in proteins.

- Recovery and extraction of proteins, fibrous materials and bioactive compounds (mainly polyphenols) and increase of the functionality considered in terms of technological use (stabilization of emulsions and dispersions, flow capacity and viscosity modifications, emulsifying 
activity improvement, etc.). Mechanical stresses and hydrodynamic effects induce cell disruption, favoring the release of intracellular content or structural components of the cell wall. Moreover, dispersed particles or fat droplets can be reduced in size and modified in structure.

- Increase of functionality in terms of health effect (increase bioaccessibility, bioavailability or probiotic effect). These effects result from favoring the release of bioactive compounds, the modification of biopolymer structures and the development of novel particle interactions and networking. Micro- or nano- capsules have also been developed.

In order to numerically quantify its evolution, the increase in the number of published scientific articles (in \%) was calculated, taking into account the difference in the number of items between the last two decades. The results in each of the considered areas are included in Figure 1a,b. As shown in Figure 1a, between 2000 and 2009, HPH were used mainly for the extraction of proteins, although a large number of research works focused on microorganisms and enzymes inactivation, contributing to food preservation and safety. The last decade (from 2010 until now) revealed a significant increase $\mathbf{7 4 . 8 7 \% )}$ in the total number of scientific articles published. The main areas in which there was an increase greater than the total value were the use of $\mathrm{HPH}$ for microorganism inactivation, fiber extraction, and above all, bioactive and probiotic components.

The application of HPH to extract or increase the functionality of bioactive compounds, and to improve the probiotic effect, grew by $89 \%$ and $87.9 \%$ respectively (Figure $1 \mathrm{a}$ ). The increasing interest among consumers and the food industry in improving the organoleptic and nutritional quality of foods, along with concern for the valorization of food waste, might explain this result.

Figure $1 b$ shows the evolution in the number of published research works related to the application of $\mathrm{HPH}$ according to food type. Although the majority of works focused on fruit juices, the largest growth occurred in plant-based beverages and food waste. The huge increase in the consumption of plant-based beverages [5] and general concern about 
food waste-related issues are responsible for this increase. $\mathrm{HPH}$ technology is recognized as a green technology due to short processing times, low energy consumption, low $\mathrm{CO} 2$ emissions and the fact that it does not require polluting solvents.
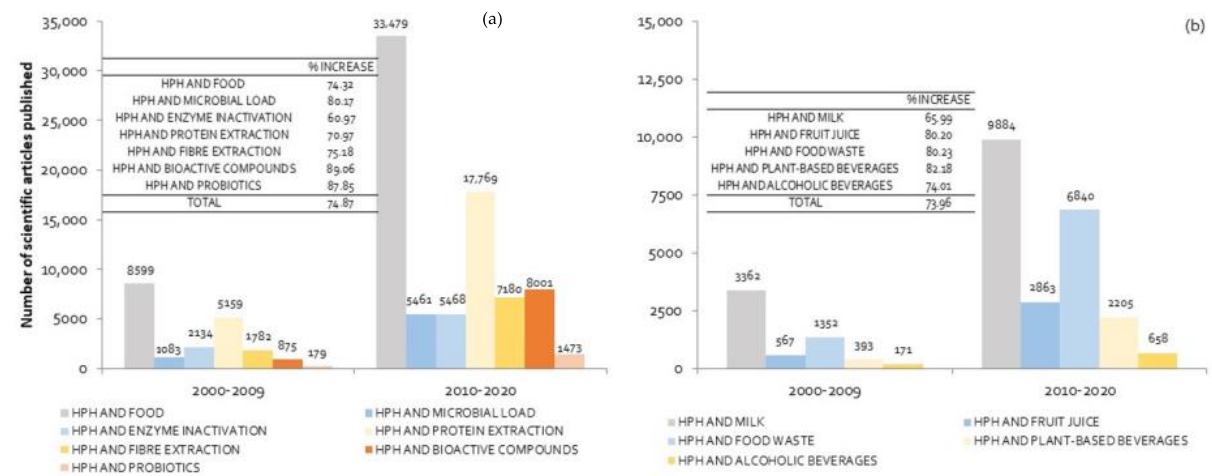

Figure 1. Number of scientific articles published according to areas of application of HPH in the food industry (a) and the different types of food with which it has been used (b). \% INCREASE was calculated as the difference in the number of articles published between 20102020 and 2000-2009, divided by the number of articles published in the period 2000-2009, expressed as a percentage. (Source: Science Direct. The following keywords and their combinations were used as the main search terms: high homogenization pressures, nonthermal technologies, food processing, encapsulation, functional food, bioactive components, probiotics, microbial load, enzyme inactivation, protein extraction, milk, fruit juice, food waste, plant-based beverages and alcoholic beverages).

This increase in research works based on HPH technology is also due to the development of new homogenization equipment that works at elevated pressures (i.e., up to $400 \mathrm{MPa}$ ) and supports specific conditions. Since the invention of adjustable valves in 1930 [6], the potential of homogenization technology has increased. The geometry and design of the valve determines the mechanical effect on the treated fluid. In 1982, the invention of the Gaulin Micro-Gap valve [7] greatly boosted the efficiency of the process, making high homogenization pressures possible in subsequent years and leading, more recently, to the development of ultrahigh homogenization pressure technology. In general, improvements have been obtained in all fields of application, making HPH an efficient tool with great potential for use in the food industry [8]. 


\section{Preservation and safety}

$\mathrm{HPH}$ treatment for enzyme and microbial inactivation has been used in recent years as an alternative to thermal processes that, in most cases, cause undesirable effects such as nonenzymatic browning, cooked flavor or degradation of valuable components (see Tables 1 and 2). It has been demonstrated that $\mathrm{HPH}$ treatment at processing pressures higher than $100 \mathrm{MPa}$ contributes to microbial load reduction and enzyme inactivation. As previously stated, the heating that occurs in homogenization (an increase of about $2.5^{\circ} \mathrm{C}$ per $10 \mathrm{MPa}$ ), together with structural modifications of cell walls, are the main phenomena responsible for the inactivation of microorganisms or enzymes.

The final impact of HPH on microorganism viability or enzyme activity depends on several factors such as processing pressure, microbial strain or enzyme and food matrix. In general, it has been verified that gram-negative bacteria exhibit greater susceptibility to inactivation by $\mathrm{HPH}$ than gram-positive ones, due to the reduced content of peptidoglycan in the cell wall that makes it thinner, and therefore, easier to disrupt. Fungi and yeasts seem to have a susceptibility that is intermediate between gram-positive and gram-negative bacteria, probably due to their wall structure, which is thicker but more complex than that of gram-positive bacteria [9]. For the inactivation of bacterial spores, pressures up to $400 \mathrm{MPa}$ and additional steps are required [8]. 
Table 1. Research works evaluating the decrease in microbial load in different food products by HPH.

\begin{tabular}{|c|c|c|c|c|c|}
\hline Product & Treatment & Terms & Microbiologic Control & Results & Reference \\
\hline $\begin{array}{l}\text { Fruit juices (apricot and } \\
\text { carrot) }\end{array}$ & $\mathrm{HPH}+$ rapid cooling & $100 \mathrm{MPa}$ (1-8 passes) & Zygosaccharomyces bailii 45 & $\begin{array}{l}\text { The juice type affected the yeast fate (growth or death) and } \\
\text { viscosity change after HPH treatment. }\end{array}$ & [8] \\
\hline Mango nectar & $\mathrm{HPH}+$ thermal shock & $\begin{array}{c}200 \mathrm{MPa} \\
10-20 \mathrm{~s} \text { at } 60-85^{\circ} \mathrm{C}\end{array}$ & A. niger ( $\mathrm{COI} 4573)$ & $\begin{array}{l}\text { The combination of HPH with subsequent thermal shock was } \\
\text { efficient in inactivating heat resistant mold in mango nectar. }\end{array}$ & [10] \\
\hline Banana juice & HPH + rapid cooling & $0,150,200,300$ and $400 \mathrm{MPa}$ & Total mesophilic bacteria & $\begin{array}{l}\text { Pressures greater than } 200 \mathrm{MPa} \text { were required to obtain a } \\
\text { reduction of four logarithmic units. }\end{array}$ & [11] \\
\hline Apricot juice & $\mathrm{HPH}+$ citral + rapid cooling & $100 \mathrm{MPa}(1,3,5$ and 8 passes $)$ & Saccharomyces cerevisiae SPA & $\begin{array}{l}\text { Decrease of the viability of the yeasts following a linear } \\
\text { tendency with pressure. Improvement of the antimicrobial } \\
\text { effect by adding citral. }\end{array}$ & [12] \\
\hline $\begin{array}{l}\text { Mango juice (Mangifera } \\
\text { indica L.) }\end{array}$ & $\mathrm{HPH}+$ heat treatment & 40-190 MPa (1-5 passes) & Total plate count, molds and yeasts & $\begin{array}{l}\text { Complete inactivation of molds and yeasts was achieved by one } \\
\text { and three passes at } 190 \mathrm{MPa} \text { and } 60{ }^{\circ} \mathrm{C} \text {, while the total plate } \\
\text { count was less than } 2.0 \log \mathrm{CFU} / \mathrm{mL} \text {. }\end{array}$ & [13] \\
\hline $\begin{array}{l}\text { Mulberry juice (Morus } \\
\text { atropurpurea Roxb.) }\end{array}$ & $\begin{array}{l}\text { HPH + heat treatment + } \\
\text { Addition of Dimethyl } \\
\text { Dicarbonate (DMDC) }\end{array}$ & $200 \mathrm{MPa}$ (1-3 passes) & $\begin{array}{l}\text { Total count, yeast, mold and lactic } \\
\text { acid bacteria }\end{array}$ & $\begin{array}{l}\text { Combination treatment with three passes at } 200 \mathrm{MPa} \text { and } 250 \\
\mathrm{mg} \mathrm{DMDC} / \mathrm{L} \text { decreased total count to the level reached by heat } \\
\text { treatment at } 95^{\circ} \mathrm{C} \text {. }\end{array}$ & [14] \\
\hline Lupine based drinks & $\mathrm{HPH}+$ refrigeration & 50,100 and $175 \mathrm{MPa}(2,4,6$ passes $)$ & $\begin{array}{c}\text { Total bacterial count, molds and } \\
\text { yeasts. Bacillus cereuses and coliform } \\
\text { bacteria }\end{array}$ & $\begin{array}{l}\text { At } 175 \mathrm{MPa} \text {, yeasts, molds and coliforms were completely } \\
\text { eliminated with two and four passes }\end{array}$ & [15] \\
\hline Granada juice & $\begin{array}{l}\mathrm{HPH}+\text { low temperature } \\
\text { pasteurization }\end{array}$ & $\begin{array}{l}100,150 \mathrm{MPa} \text { (10 passes) } 55 \text { or } 65^{\circ} \mathrm{C} \\
\text { for } 15 \mathrm{~s}\end{array}$ & $\begin{array}{c}\text { Escherichia coli (ATCC 26) and } \\
\text { Saccharomyces pastorianus (ATCC } \\
42376 \text { ) }\end{array}$ & $\begin{array}{l}\mathrm{HPH} \text { at } 150 \mathrm{MPa} \text { followed by a low heat intensity at } 65^{\circ} \mathrm{C} \text { for } \\
15 \mathrm{~s} \text { showed a reduction of } 3 \log \mathrm{CFU} / \mathrm{mL} \text {. }\end{array}$ & [16] \\
\hline
\end{tabular}




\begin{tabular}{|c|c|c|c|c|c|}
\hline Skim milk & Heat treatment $+\mathrm{HPH}$ & $100-300 \mathrm{MPa}$ & $\begin{array}{c}\text { Bacillus stearothermophilus ATCC } \\
7953 \text { and Clostridium sporogenes PA } \\
3679\end{array}$ & $\begin{array}{l}\text { The efficacy of HPH is similar to pasteurization and must be } \\
\text { combined with other conservation techniques. }\end{array}$ & [17] \\
\hline Milk & Heat treatment $+\mathrm{HPH}$ & $300 \mathrm{MPa}$ & $\begin{array}{c}\text { Spores of B. cereus, } \\
\text { B. lincheniformis, } \\
\text { B.sporothermodurans, } \\
\text { B. coagulans, } \\
\text { B.stearothermophilus, } \\
\text { and B. subtilis }\end{array}$ & $\begin{array}{c}\text { Sterility at } 300 \mathrm{MPa} \text { can be achieved with an initial milk } \\
\text { temperature of } 85^{\circ} \mathrm{C} \text {. }\end{array}$ & [18] \\
\hline $\begin{array}{l}\text { Skim and whole milk } \\
\text { concentrates }\end{array}$ & Heat treatment $+\mathrm{HPH}$ & $\begin{array}{l}\text { Skim milk: 0,20,50,70, } 100,120 \text { and } \\
\qquad 150 \mathrm{MPa} \text {. } \\
\text { Whole milk: } 0,20,30,35 \text { and } 40 \mathrm{MPa} \text {. }\end{array}$ & $\begin{array}{l}\text { Total count, coliforms, } \\
\text { enterobacteriaceae, molds and } \\
\text { yeasts and Staphylococco }\end{array}$ & $\begin{array}{l}\mathrm{HPH} \text { at } 120 \mathrm{MPa} \text { completely inactivates the microbial load of } \\
\text { milk concentrates. }\end{array}$ & [19] \\
\hline Almond beverages & Heat treatment $+\mathrm{HPH}$ & $200,300 \mathrm{MPa}$ (1,2 passes) & $\begin{array}{l}\text { Micrococcaceae, Bacillus cereus and } \\
\text { Mesophilic aerobic bacteria }\end{array}$ & $\begin{array}{l}\text { Complete elimination of microbial growth when working with } \\
\text { the highest pressure and with an inlet temperature of } 65-75 \\
\qquad{ }^{\circ} \mathrm{C} \text {. }\end{array}$ & [20] \\
\hline Rice drink & $\mathrm{HPH}+$ sonication & 50-100 MPa (1-3 passes) & $\begin{array}{c}\text { Lactobacillus Plantarum, } \\
\text { Lactobacillus Casei, y Bifidobacterium } \\
\text { Animalis }\end{array}$ & $\begin{array}{l}\text { Reduction and elimination of postacidification by lactic acid } \\
\text { bacteria. }\end{array}$ & [21] \\
\hline Tiger nuts' milk beverage & $\mathrm{HPH}+$ refrigeration & 200 and $300 \mathrm{MPa}$ & $\begin{array}{l}\text { Psychotropic bacteria, Lactobacilli, } \\
\text { Enterobacteriaceae and fecal } \\
\text { coliforms }\end{array}$ & $\begin{array}{l}\text { Improved shelf life and microbial inactivation compared to } \\
\text { other heat treatments. }\end{array}$ & [22] \\
\hline
\end{tabular}




\begin{tabular}{|c|c|c|c|c|c|}
\hline Lager beer & $\mathrm{HPH}$ + lysozyme addition & 0-300 MPa & Lactobacillus brevis (ССT 3745) & $\begin{array}{c}\text { The inhibitory concentration of lysozyme against } L \text {. brevis was } \\
100 \mathrm{mg} / \mathrm{L} \text {. HPH at } 100,140 \text { and } 150 \mathrm{MPa} \text { promoted decimal } \\
\text { reductions of } 1,3 \text {, and } 6 \text { in microbial counts. }\end{array}$ & [23] \\
\hline Pilsen beer & Heat treatment $+\mathrm{HPH}$ & $\begin{array}{c}100,150,200 \text { and } 250 \mathrm{MPa}(1-3 \\
\text { passes })\end{array}$ & Lactobacillus del brueckii & $\begin{array}{l}\text { It is possible to inactivate the most common microorganisms } \\
\text { that cause beer deterioration at } 250 \mathrm{MPa} \text {. The effect increases } \\
\text { with increasing the number of passes. }\end{array}$ & [24] \\
\hline Wine & Chemical treatment $+\mathrm{HPH}$ & $0,50,100$ and $150 \mathrm{MPa}$ & Saccharomyces bayanus & $\begin{array}{l}\text { HPH at } 150 \mathrm{MPa} \text { was the best treatment, inducing yeast } \\
\text { autolysis; also suitable for the acceleration of sur lie } \\
\text { maturation. }\end{array}$ & [25] \\
\hline
\end{tabular}


Significant work has been undertaken on the use of HPH to reduce microbial load in fruit juices. In this type of food, it has been observed that the presence of some aroma compounds and essential oils can greatly influence the effect of HPH treatment. Patrignani et al. [12] studied the effect of the number of passes and citral addition on the spoilage microbiota of apricot juice when subjected to $\mathrm{HPH}$ at $100 \mathrm{MPa}$. Their results showed that yeast cell viability decreased with the increase of passes, and the relationship between both variables followed a linear trend. Moreover, the citral addition enhanced the effect of $\mathrm{HPH}$, increasing the storage time by 6-8 days. To analyze the effect of the food matrix, the same authors compared the effect of $\mathrm{HPH}$ treatment at $100 \mathrm{MPa}$ on the viability loss of S. cerevisiae 635 inoculated at a level of about 6.0 Log10 CFU/mL in apricot juice and carrot juice. In apricot juice, a significant decrease in the viability of 2.2 logarithmic cycles per $\mathrm{mL}$ was obtained with only four repeated passes at $100 \mathrm{MPa}$. A further increase of the number of passes at $100 \mathrm{MPa}$ did not significantly increase the effectiveness of HPH treatment.

Concerning carrot juice, eight repeated passes at $100 \mathrm{MPa}$ were unable to completely inactivate the inoculated cells. They concluded that because of the higher viscosity and sugar content, apricot juice required more passes in $\mathrm{HPH}$ treatment to reduce yeast load [26]. In contrast, Zygosaccharomyces bailii 45 exhibited the same susceptibility to HPH treatment in both juices. Eight passes at $100 \mathrm{MPa}$ resulted in a yeast inactivation higher than $2.5 \log \mathrm{CFU} / \mathrm{mL}$, regardless of the juice considered [27]. Nevertheless, Benjamin and Gamrasni [16] showed that HPH treatment at 100 and $150 \mathrm{MPa}$ was not sufficient to reduce total bacteria and yeast count in pomegranate juice; rather, it needed to be combined with a thermal treatment at $65^{\circ} \mathrm{C}$ for $15 \mathrm{~s}$ to achieve the same effect as pasteurization at 75 ${ }^{\circ} \mathrm{C}$.

Besides fruit juices, plant-based beverages are complex dispersions with suspended proteins and oil droplets that require a homogenization stage to stabilize them and extend their commercial life. HPH can be applied at pressures higher than $100 \mathrm{MPa}$ using multiple passes for these purposes, along with microbial cells destruction [21,22]. Valencia-Flores et al. [20] compared the effect on bacterial growth of $\mathrm{HPH}$ at 200-300 MPa and soft temperature inlet $\left(55-75^{\circ} \mathrm{C}\right)$ with conventional pasteurization treatment $\left(90^{\circ} \mathrm{C}, 90 \mathrm{~s}\right)$ in an almond beverage. They showed that $200 \mathrm{MPa}$ and an inlet temperature of 55 
${ }^{\circ} \mathrm{C}$ yielded better results than conventional pasteurization on microbiological quality.

Beer is another beverage which may be treated with HPH. Research has established that it is possible to completely inactivate microorganisms in addition to improving the color of beer by HPH at pressures between 200-300 $\mathrm{MPa}$ and with 1 to 3 passes. The addition of antimicrobials such as lysozyme enzyme $(50 \mathrm{mg} / \mathrm{L}$ ) had a synergistic effect, reducing the required pressure to 100-150 MPa. However, HPH treatment could result in greater values for turbidity, and it would be necessary to perform another stabilization treatments to minimize the negative effects $[23,24]$.

$\mathrm{HPH}$ treatment has also been used to modulate the activity of various enzymes. This treatment can increase or decrease enzyme activity depending on the processing conditions (pressure and number of passes), homogenizing valve structure, specific enzyme, $\mathrm{pH}$, temperature and food matrix. Since enzymes are a complex type of globular protein, the mechanical forces and cavitation effects associated with HPH treatment result in conformational and structural changes which modify enzyme activity and stability. The main modifications in enzymes are linked to changes in the quaternary, tertiary and even secondary structures. The formation or interruption of hydrogen bonds, Van der Waals, hydrophobic and electrostatic interactions can occur, increasing the number of hydrophobic sites, revealing amino acid and sulfhydryl groups, and thus, accelerating, delaying or impeding enzymesubstrate interactions [24]. Furthermore, the magnitude of the changes induced by the HPH treatment will determine their reversibility or irreversibility. Aguilar et al. [28] noted that protein denaturation can be reversible at $100 \mathrm{MPa}$, but that it is irreversible above $200 \mathrm{MPa}$.

In the case of juices, the main alteration reactions are caused by the polyphenoloxidase, which is responsible for browning and oxidation reactions; it was shown that it was possible to inactivate it with homogenization pressures of $80-150 \mathrm{MPa}[29,30]$. On the other hand, $\alpha$-amylase-whose use in recent years has been increasing, since it reduces the starch content in beverages, thereby avoiding turbidity and gelatinization -is resistant to HPH [31]. A similar resistance was observed on Pseudomonas fluorescens protease when HPH at 100-150 MPa was applied to reduce its proteolytic rate [32]. 
Table 2. Research works evaluating enzyme activity modulation by HPH.

\begin{tabular}{|c|c|c|c|c|}
\hline Product & Enzymes & Treatment & Effect & Reference \\
\hline $\begin{array}{l}\text { Commercial } \\
\text { enzymes }\end{array}$ & Glucose oxidase & $50,100,150 \mathrm{MPa}$ & $\begin{array}{l}\text { Decrease in enzyme } \\
\text { activity at } 50 \mathrm{MPa} \text {. } \\
\text { Improvement in activity } \\
\text { and stability at } 100 \text { and } \\
150 \mathrm{MPa}\end{array}$ & [33] \\
\hline $\begin{array}{l}\text { Commercial } \\
\text { enzymes }\end{array}$ & $\begin{array}{l}\text { Amyloglucosidase, } \\
\text { Glucose oxidase, } \\
\text { Neutral protease }\end{array}$ & $\begin{array}{l}\text { Amyloglucosidase, } \quad \text { neutral } \\
\text { protease: } 150,200 \mathrm{MPa}(3 \\
\text { passes). Glucose oxidase: } 100, \\
150 \mathrm{MPa} \text { ( } 3 \text { passes) }\end{array}$ & $\begin{array}{l}\text { Improvement of enzymatic } \\
\text { activity }\end{array}$ & [24] \\
\hline Fruit juices & $\alpha$-amilase & $0,40,80,120$ and $150 \mathrm{MPa}$ & Stability of the enzyme & [31] \\
\hline Apple juice & Polyphenoloxidase & $150 \mathrm{MPa}$ (10 passes) & Inactivation & [29] \\
\hline $\begin{array}{l}\text { Lettuce waste } \\
\text { juice }\end{array}$ & Polyphenoloxidase & $\begin{array}{l}80 \mathrm{MPa} \text { ( } 1 \text { pass) and } 150 \mathrm{MPa} \\
\text { (1-10 passes) }\end{array}$ & Inactivation & [30] \\
\hline $\begin{array}{l}\text { Peanut } \\
\text { protein }\end{array}$ & Alcalase & $0,1,40$ and $80 \mathrm{MPa}$ & $\begin{array}{l}\text { Increased enzymatic } \\
\text { hydrolysis. }\end{array}$ & [34] \\
\hline $\begin{array}{l}\text { Chicken egg } \\
\text { white }\end{array}$ & Lysozyme muramidase & $40,80,120,160$ and $190 \mathrm{MPa}$ & $\begin{array}{l}\text { Activation and increase of } \\
\text { enzymatic activity. }\end{array}$ & [35] \\
\hline Raw skim milk & $\begin{array}{l}\text { Alkaline phosphatase } \\
\text { and lactoperoxidase }\end{array}$ & $100,150,200,250$ and $300 \mathrm{MPa}$ & $\begin{array}{l}\text { Decrease and inactivation } \\
\text { of alkaline phosphatase. } \\
\text { Increased activity of } \\
\text { lactoperoxidase. }\end{array}$ & [17] \\
\hline Milk & $\begin{array}{l}\text { Protease Pseudomonas } \\
\text { fluorescens }\end{array}$ & 100 and $150 \mathrm{MPa}$ & Decreased proteolytic rate & [32] \\
\hline
\end{tabular}

On the other hand, HPH can also be applied to enhance enzyme activity. Some authors have applied HPH to increase the activity of enzymes involved in the shelf life or processing of several food matrices. Lysozyme and lactoferrin in milk increased their antimicrobial activity against $L$. monocytogenes after $\mathrm{HPH}$ at $100 \mathrm{MPa}[8,36]$. Pinho et al. [17] observed an increase in the enzymatic activity of lactoperoxidase in skim milk at pressures of between 100 and $250 \mathrm{MPa}$. In contrast, if the homogenization pressure increased up to $300 \mathrm{MPa}$, a reduction of around $30 \%$ in enzyme activity was detected. In another work, defatted peanut flour was dispersed in distilled water and $\mathrm{pH}$ adjusted, and further subjected to $\mathrm{HPH}$ treatment at 40 and 80 $\mathrm{MPa}$. After that, the peanut protein was recovered from the dispersed solution by an acid precipitation and redispersed in distilled water. The HPH treatment increased the extraction yield and the hydrolysis of the peanut protein isolates by endogenous enzymes. DPPH radical scavenging and hydroxyl radical scavenging activities were also increased [34]. 
It was shown that low cost, versatility and performance improvement of enzymatic processes can be achieved when the activity of commercial enzymes is increased by $\mathrm{HPH}$. In particular, Tribst et al. [24] improved the activity of amyloglucosidase, glucose oxidase and neutral protease using HPH between 100-150 MPa and nonoptimum temperatures. Commercial enzymes derived from fungi and available as powders were diluted in acetate buffer solutions and then subjected to HPH treatment. Tribst et al. [24] observed an uneven effect of the number of passes. Only one pass was required to increase the activity of amyloglucosidase and neutral protease, and while no effect was observed in subsequent passes, successive steps continued to increase the enzyme activity of glucose oxidase; the energy involved in the molecular changes associated with the increase in enzyme activity might be responsible for this.

\section{Extraction and technological functionality improvement of proteins, fibrous materials and bioactive compounds}

$\mathrm{HPH}$ has been used in recent years to contribute to food process sustainability [5]. In this area, HPH has been applied for the valorization of agrifood byproducts with two objectives: (i) to increase the extractability of intracellular or cell wall structural components, and (ii) to improve the technological functionality of biomolecules from food byproducts. Most agrifood wastes or byproducts are rich in fibrous material and, in some cases, in proteins or bioactive compounds which are of interest to the food industry for use as food ingredients [37] or as sustainable packaging materials [38]. HPH induces cells disruption, favoring the release of structural and intracellular contents.

The main kind of products with which HPH is used to extract fibers, proteins or bioactive compounds are solid byproducts, such as pomace from fruit or vegetable juicing, fruit or vegetable peels, minimal processing waste and vegetal parts of plants or cereal seed hulls; the most important examples are included in Table 3. In these cases, solid wastes need to be fluidized by diluting them in water or another solvent. In other cases, an extraction method is applied and the extracted phase is further subjected to HPH. The authors of [39] extracted pectin form potato peel by HPH at $200 \mathrm{MPa}$. They obtained improvements in the viscosity, emulsifying properties, degree of esterification and physicochemical characteristics, and therefore, recommended the use of $\mathrm{HPH}$ to obtain pectin that could be used as a 
stabilizing agent or a thickener in food manufacturing. Similarly, Fayaz et al. [40] showed that HPH favors the release of okara proteins and soluble fiber. Soy okara was dispersed in deionized water at $10 \mathrm{~g} / 100 \mathrm{~g}$ and prehomogenized with a high-speed blender. After that, a homogenization pressure of $150 \mathrm{MPa}$ for 5 passes made it possible to extract proteins with a yield of $90 \%$. The authors of [41] applied $\mathrm{HPH}$ to make edible and biodegradable films for food packaging from a type of edible fungus, i.e., Flammulina velutipes. Wu et al. [42] demonstrated the possibility of using HPH treatment to make biodegradable biopolymer films from pomelo peel.

$\mathrm{HPH}$ reduces the particle size and structure of macromolecules, modifying their solubility, interaction properties, viscosity, or other physicchemical properties. Saricaoglu et al. [43] improved the functionality of proteins from the hazelnut industry by $\mathrm{HPH}$ at $100 \mathrm{MPa}$ and 1 pass. The homogenization pressure decreased the particle size of proteins, increasing their zeta potential and water solubility; emulsifying and sparkling properties were improved too. Hua et al. [44] demonstrated a microstructural change of tomato waste fibers by applying $\mathrm{HPH}$ at $100 \mathrm{MPa}$ and 10 passes. The authors transformed around $8 \%$ of the insoluble fibers into soluble ones. Xu et al. [45] indicated that for the preparation of soluble peach fiber from fresh peach marc, it must be dispersed in three times the volume of deionized water, thus improving the efficiency of cellulose hydrolysis. For pectin extraction from milled dried lemon peel, variations in dilutions changed the properties of the extracted pectin, resulting in residues with different pectic characteristics [46]. Discarded external lettuce leaves were dispersed in hydroalcoholic solutions and polyphenols extracted with ethanol to obtain good phenolic extraction yields [47].

Table 3. Research works aimed to the extraction and improvement of technological functionality of proteins, fibers or bioactive compounds from agri-food wastes by HPH.

\begin{tabular}{|c|c|c|c|c|}
\hline Substrate & Component & Treatment & Objective & Reference \\
\hline Sweet potato leaves & Flavonoids & $100 \mathrm{MPa}$ (2 passes) & $\begin{array}{l}\text { Strengthens the antioxidant } \\
\text { activities of the flavonoid. }\end{array}$ & [48] \\
\hline Potato peel & Biopolymer film & $150 \mathrm{MPa}$ & Extraction & [49] \\
\hline Peach pomace & Soluble fibers & $140 \mathrm{MPa}$ (4 passes) & $\begin{array}{l}\text { Significantly improved the } \\
\text { efficiency of cellulase hydrolysis in } \\
\text { the preparation of soluble fibers } \\
\text { and a high binding capacity for } \\
\text { sodium cholate and cholesterol. }\end{array}$ & {$[45]$} \\
\hline
\end{tabular}




\begin{tabular}{|c|c|c|c|c|}
\hline Potato peel & Phenolic acids & $\begin{array}{l}159 \mathrm{MPa}(2 \\
\text { passes })+\mathrm{NaOH} \\
\text { treatment }\end{array}$ & $\begin{array}{l}\text { Improved extraction and release of } \\
\text { total phenolic content and total } \\
\text { flavonoid content. }\end{array}$ & [37] \\
\hline $\begin{array}{l}\text { Desmodesmus sp. } \\
\text { F51 }\end{array}$ & Carotenoids & $\begin{array}{l}69-276 \mathrm{MPa}(1- \\
4 \text { passes) }\end{array}$ & Extraction & {$[50]$} \\
\hline $\begin{array}{l}\text { Dry tomato residue } \\
\text { waste }\end{array}$ & Fibers & $\begin{array}{l}100 \mathrm{MPa} \quad(10 \\
\text { passes })\end{array}$ & $\begin{array}{l}\text { Improved the soluble fiber content } \\
\text { and its oil holding capacity. }\end{array}$ & [44] \\
\hline Citrus peel & Fibers & $\begin{array}{l}\text { 90, } 160 \mathrm{MPa}(2 \\
\text { passes) }\end{array}$ & $\begin{array}{l}\text { Improvement of physical, } \\
\text { chemical, and functional properties } \\
\text { including surface area, water } \\
\text { holding capacity, texture and } \\
\text { viscosity. }\end{array}$ & [51] \\
\hline Lemon peels fiber & Pectin & 20 and $80 \mathrm{MPa}$ & Extraction & {$[46]$} \\
\hline Soybean & Protein & $100 \mathrm{MPa}$ & Extraction & {$[52]$} \\
\hline $\begin{array}{l}\text { Hazelnut } \quad \text { oil } \\
\text { industry } \\
\text { products }\end{array}$ & $\begin{array}{l}\text { Hazelnut } \\
\text { proteins }\end{array}$ & $\begin{array}{l}0,25,50,75,100 \\
\text { and } 150 \mathrm{MPa}\end{array}$ & 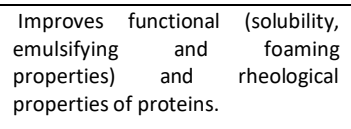 & [53] \\
\hline $\begin{array}{l}\text { Black cherry } \\
\text { tomato waste }\end{array}$ & Pectin & $\begin{array}{l}0,40,80,120 \\
\text { and } 160 \mathrm{MPa}(2 \\
\text { passes) }\end{array}$ & $\begin{array}{l}\text { Increase the esterification degree } \\
\text { of pectins. }\end{array}$ & {$[54]$} \\
\hline $\begin{array}{l}\text { Carrot processing } \\
\text { waste }\end{array}$ & $\begin{array}{l}\text { Biodegradable } \\
\text { composite films } \\
\text { were prepared }\end{array}$ & $\begin{array}{l}138 \mathrm{MPa} \quad(7 \\
\text { passes })\end{array}$ & Extraction & [55] \\
\hline Lettuce waste & Polyphenols & $50,100 \mathrm{MPa}$ & Extraction & {$[47]$} \\
\hline Potato peel & Pectin & $200 \mathrm{MPa}$ & $\begin{array}{l}\text { Increased galacturonic acid } \\
\text { content, viscosity and emulsifying } \\
\text { properties. Decreased } \\
\text { esterification degree and molecular } \\
\text { weight. }\end{array}$ & [39] \\
\hline Broccoli seeds & Sulforaphane & $\begin{array}{l}20-160 \mathrm{MPa}(1- \\
5 \text { passes })\end{array}$ & Increases the extraction yield. & [56] \\
\hline $\begin{array}{l}\text { Agri-food waste } \\
\text { (tomato peel, } \\
\text { coffee beans) }\end{array}$ & $\begin{array}{lr}\text { Application } & \text { for } \\
\text { structuring } & \text { peanut } \\
\text { oil } & \end{array}$ & $\begin{array}{l}70 \mathrm{MPa} \quad(3 \\
\text { passes) }\end{array}$ & $\begin{array}{l}\text { Replacing part of the lipids with } \\
\text { water and low calorie fibers. }\end{array}$ & [57] \\
\hline $\begin{array}{l}\text { Edible mushroom } \\
\text { by-products }\end{array}$ & $\begin{array}{l}\text { Biodegradable } \\
\text { edible film }\end{array}$ & $\begin{array}{l}100 \mathrm{MPa} \quad(3 \\
\text { passes) }\end{array}$ & $\begin{array}{l}\text { Improve tensile strength, } \\
\text { elongation at break, water vapor } \\
\text { permeability, oxygen barrier and } \\
\text { thermal stability. }\end{array}$ & {$[41]$} \\
\hline $\begin{array}{lr}\text { Grape } & \text { seeds, } \\
\text { tomato } & \text { stem, } \\
\text { walnut } & \text { shells, } \\
\text { coffee } & \end{array}$ & $\begin{array}{l}\text { Polyphenolic } \\
\text { compounds and } \\
\text { antioxidants }\end{array}$ & $\begin{array}{l}20,50,100,120 \\
\mathrm{MPa}\end{array}$ & Extraction & [58] \\
\hline Soybean okara & $\begin{array}{l}\text { Proteins and soluble } \\
\text { fibers }\end{array}$ & $\begin{array}{l}50,100,150 \\
\mathrm{MPa}(1 \text { pass }) 150 \\
\mathrm{MPa}(5 \text { pases })\end{array}$ & Extraction & {$[40]$} \\
\hline Sugar palm & $\begin{array}{l}\text { nanofibrillated } \\
\text { cellulose }\end{array}$ & $\begin{array}{l}50 \mathrm{MPa} \quad(3 \\
\text { passes })\end{array}$ & Extraction & [59] \\
\hline
\end{tabular}




\begin{tabular}{clcll}
\hline Tomato peels & $\begin{array}{l}\text { Bioactive } \\
\text { compounds: } \\
\text { proteins, } \\
\text { polyphenols, } \\
\text { lycopene }\end{array}$ & $\begin{array}{l}100 \mathrm{MPa}(1-10 \\
\text { passes) }\end{array}$ & $\begin{array}{l}\text { Increased release of intracellular } \\
\text { compounds (proteins, sugars, [60] } \\
\text { antioxidants) }\end{array}$ \\
\hline Pomelo peel & Biopolymer film & $\begin{array}{c}20,40,60 \text { and } \\
80 \mathrm{MPa}(10 \\
\text { passes) }\end{array}$ & $\begin{array}{l}\text { Improved mechanical properties, } \\
\text { microstructure, optical and barrier } \\
\text { properties. }\end{array}$ & [42] \\
\hline Soybean meal & Resins & $20 \mathrm{MPa}$ & Extraction & [61] \\
\hline
\end{tabular}

\section{Increase of bioavailability and encapsulation of bioactive compounds}

In the last decade, many studies have been carried out to demonstrate that the application of HPH to liquid foods can modify the bioaccessibility (i.e., the fraction of an ingested nutrient that is released from the food matrix and made available for intestinal absorption) or bioavailability (i.e., the fraction of an ingested nutrient that is absorbed by the intestine and incorporated into the bloodstream) of its bioactive compounds. In most studies, an increase in the bioaccessibility of phytochemicals was observed due to their release within the structure of the food in which they were found. In other cases, a modification of biological functionality occurs due to a change in its chemical structure. Zhou [62] carried out an interesting review that demonstrated these effects in three bioactive components: carotenoids, phenolic compounds, and vitamin $\mathrm{C}$. The review showed that fruit juices (carrot, tomato, orange, apple and berries) are the most common food in which HPH increases the bioaccessibility of bioactive compounds. HPH decreases the particle size of suspended pulp and increases cloud stability and, thus, the availability of bioactive components.

Treatment with $\mathrm{HPH}$ in mandarin juices increased the bioaccessibility of total carotenoids by five times, although in the case of flavonoids, no such drastic changes were observed. Therefore, HPH treatment was recommended for the production of tangerine juices that promote health, mainly through the improvement of the bioaccessibility of the carotenoids contained therein [63]. Quan et al. [64] established that the improvement of bioaccessibility could be conditioned by the food matrix. They observed that $\mathrm{HPH}$ at $250 \mathrm{MPa}$ favored the release from cell walls and increased the content of total phenolic compounds in kiwi and pomelo juices, but that it had a negative effect on its bioaccessibility (in vitro) as a consequence of the major degradation that 
occurred in the digestion process. Conversely, the addition of skimmed or whole milk to the juices had no significant effect on total phenolic content, but increased their bioaccessibility in kiwi juice and pomelo juice from $21.6 \%$ to $37.8 \%$ and $60.1 \%$ to $63.3 \%$, respectively. Similarly, Alongi et al. [65] showed (in vitro) that the bioaccessibility of chlorogenic acids increased from nearly $25 \%$ to more than $50 \%$ by adding milk with different fat contents to coffee and applying HPH (50-150 MPa). Alongi et al. [65] observed that the pressure required was lower the lower the fat percentage; they attributed this effect to the micellarization of chlorogenic acids, a phenomenon that reduced their susceptibility to degradation during digestion. Sometimes, positive effects of HPH were observed after storage. Betoret et al. [66] found in low pulp mandarin juice that, despite the increase in suspended pulp after HPH and trehalose addition, flavonoid hesperidin initially decreased but resulted in less flavonoid degradation during storage.

$\mathrm{HPH}$ s have also been applied, albeit with a much smaller number of published articles, to nondairy, vegetable-based beverages. Although, in some cases, no significant improvements in the nutritional characteristics were detected, in others, such as almond or soy beverages, a reduction in antinutrients was achieved [67]. The denaturation, aggregation and chemical modification of proteins may change their allergic potential. Toro- Funes et al. [68] demonstrated an increase of $40 \%$ in the extractability of phytosterols from almond milk subjected to a $\mathrm{HPH}$ of $300 \mathrm{MPa}$ (6 passes). However, the content of tocopherol and polyamines such as spermidine were reduced by up to $90 \%$. The application of HPH for kefir production from a hazelnut beverage achieved improvements in the total content of phenolic compounds and antioxidant capacity, causing a reduction in the content of lactic and citric acid [69].

Improvements in the bioavailability of bioactive components by $\mathrm{HPH}$ are also possible in solid foods. HPH (10-20 cycles and 100-200 MPa) was used to fabricate an aqueous nanosuspension of fermented soybean powder, favoring in vitro release of isoflavones from nanosuspension [70].

The other way in which HPH can contribute to improvements in the nutritional properties of foods is by using this technology for the encapsulation of bioactive components (see Table 4). In this way, it is possible to increase the stability, conservation and controlled delivery to target sites, thereby increasing food functionality. HPH produces intense disruptive forces 
that break up particles into smaller sizes, favoring the encapsulation of specific components in a suitable media. Mechanical stress and heating associated and emulsifier interactions can affect the effectiveness of the process, and therefore, the activity and bioaccessibility of the bioactive compound.

Many studies have investigated the nanoencapsulation of curcumin by $\mathrm{HPH}$ at 40-100 MPa. The results showed that the emulsifier type had an influence on the bioaccessibility of curcumin [71]. Frank et al. [72] studied the degradation of anthocyanins from bilberry extract by subjecting them, by HPH, to temperature and mechanical stresses similar to those involved in the process of emulsification and encapsulation. HPH was applied with a simple pass and in a pressure range between 30 and $150 \mathrm{MPa}$. Thereafter, the samples were immediately cooled to $298 \mathrm{~K}$. The results showed no significant influence of mechanical stresses associated with HPH on anthocyan in stability, even at high-pressure treatment, i.e., up to $150 \mathrm{MPa}$. The combination temperature-time was the main parameter affecting the degradation of anthocyanin.

A great level of interest has been shown in applying HPH as an encapsulation technique in bacteria with probiotic effects. Patrignani et al. [73] underlined the potential of the $\mathrm{HPH}$ microencapsulation of probiotic microorganisms to produce fermented milk with improved functionality and enhanced sensory properties. They established $50 \mathrm{MPa}$ and 5 passes as being adequate conditions to produce stable microcapsules of Lactobacilli with high yield and excellent viability during storage. Moreover, the microencapsulation of adjunct bacteria reduced the acidity of fermented milk. Calabuig-Jiménez et al. [74] microencapsulated L. salivarius spp. salivarius in alginate coatings using $\mathrm{HPH}$ at $70 \mathrm{MPa}$. A positive effect of microcapsules was observed when evaluating the survival of the probiotic strain on simulated gastrointestinal conditions.

Table 4. Research works in which HPH treatment was applied to encapsulate.

\begin{tabular}{|c|c|c|c|c|}
\hline $\begin{array}{l}\text { Component } \\
\text { Encapsulated }\end{array}$ & Matrix & Conditions & Results & Reference \\
\hline $\begin{array}{l}\text { Lactobacillus } \\
\text { paracasei A13 and } \\
\text { Lactobacillus } \\
\text { salivarius subsp. } \\
\text { salivarius CET } 4063\end{array}$ & $\begin{array}{l}\text { Fermented } \\
\text { milk }\end{array}$ & $\begin{array}{l}50 \mathrm{MPa}(5 \\
\text { passes) }\end{array}$ & $\begin{array}{l}\text { The microcapsules presented } \\
\text { high yields in terms of trapped } \\
\text { viable cells and acceptable sizes. } \\
\text { Furthermore, } \\
\text { microencapsulation caused a }\end{array}$ & [73] \\
\hline
\end{tabular}


decrease in acidity in fermented

milk.

\begin{tabular}{|c|c|c|c|c|}
\hline $\begin{array}{l}\text { Phenolic } \\
\text { compounds and } \\
\text { anthocyanins from } \\
\text { blueberry pomace }\end{array}$ & - & $\begin{array}{l}50-200 \\
\mathrm{MPa}\end{array}$ & $\begin{array}{l}\text { The encapsulation efficiency, } \\
\text { size and charge characteristics of } \\
\text { the emulsion droplets were } \\
\text { affected by HPH. }\end{array}$ & [75] \\
\hline $\begin{array}{l}\text { Lactobacillus } \\
\text { salivarius } \\
\text { Salivarius }\end{array}$ & $\begin{array}{l}\text { Mandarin } \\
\text { Juice }\end{array}$ & $\begin{array}{l}70 \mathrm{MPa}(2 \\
\text { passes) }\end{array}$ & $\begin{array}{l}\text { Improving the survival of } \\
\text { probiotics with the use of } \\
\text { alginate as a coating. }\end{array}$ & [74] \\
\hline $\begin{array}{l}\text { Phenolic powder } \\
\text { from strawberry } \\
\text { pomace }\end{array}$ & - & $\begin{array}{l}50 \text { and } 70 \\
\mathrm{MPa}(3,5,7 \\
\text { passes })\end{array}$ & High encapsulation efficiency & [76] \\
\hline $\begin{array}{l}\text { L. salivarius spp. } \\
\text { Salivarius }\end{array}$ & $\begin{array}{l}\text { Mandarin } \\
\text { juice } \\
\text { impregnated } \\
\text { in apple }\end{array}$ & $\begin{array}{l}70 \mathrm{MPa}(2 \\
\text { passes) }\end{array}$ & $\begin{array}{l}\text { The final count of L. salivarius } \\
\text { spp. Salivarius encapsulation } \\
\text { was high enough to exert a } \\
\text { potential beneficial effect. }\end{array}$ & [77] \\
\hline
\end{tabular}

(-) indicates that the component has not been included in a food matrix

$\mathrm{HPH}$ treatments at pressure levels below $100 \mathrm{MPa}$, considered sublethal pressures, were applied to microbial cultures, i.e., initiators, coinitiators, or probiotics and yeasts, in order to produce cultures with improved functional, technological and sensory properties (some examples are included in Table 5). The use of strains belonging to the genus Bifidobacterium and Lactobacillus predominated as probiotics, and to a lesser extent Enterococcus, Streptococcus and Saccharomyces [8]. The bacterial cells responded to mechanical stress induced by HPH, modifying their metabolic activity and membrane composition. Therefore, technological and functional properties such as fermentation kinetic, enzymatic activities, hydrophobicity or resistance to gastrointestinal digestion can be improved. 
Table 5. Research works in which HPH treatment was applied to probiotic cells.

\begin{tabular}{|c|c|c|c|c|}
\hline Food Matrix & Microbial Strain & Conditions & Results & References \\
\hline Yogurt & $\begin{array}{l}\text { L. Delbrueckii ssp. bulgaricus } \\
\text { LB- } 12 \text {, } \\
\text { S. Salivarius ssp. thermophilus } \\
\text { ST-M5 } \\
\text { and L. acidophilus LA-K }\end{array}$ & $\begin{array}{l}0, \quad 3.45, \quad 6.90 \\
10.34 \quad \text { and } \\
13.80 \mathrm{MPa}\end{array}$ & Improved tolerance to acid and bile & [78] \\
\hline- & $\begin{array}{l}\text { L. acidophilus Dru y } L . \\
\text { paracasei A13 }\end{array}$ & 0.1 and $50 \mathrm{MPa}$ & $\begin{array}{l}\text { Increased probiotic characteristics in } \\
\text { vivo; no modification in the } \\
\text { interaction of lactobacilli with the } \\
\text { small intestine. }\end{array}$ & [79] \\
\hline- & $\begin{array}{l}\text { Lactobacillus paracasei A13, } \\
\text { Lactobacillus acidophilus } 08 \\
\text { and Dru, } \\
\text { Lactobacillus delbrueckii spp. } \\
\text { lactis } 200\end{array}$ & $50 \mathrm{MPa}$ & $\begin{array}{l}\text { Increased functional characteristics } \\
\text { depending on the type of strain. }\end{array}$ & [12] \\
\hline $\begin{array}{l}\text { Fermented } \\
\text { milks }\end{array}$ & $\begin{array}{l}\text { Lactobacillus rhamnosus } \\
\text { BFE5264, } \\
\text { L. delbrueckii spp. bulgaricus } \\
\text { FP1 } \\
\text { and Streptococcus } \\
\text { thermophilus LI3 }\end{array}$ & $60 \mathrm{MPa}$ & $\begin{array}{l}\text { Reduced product clotting time and } \\
\text { increased viability of the probiotic } \\
\text { strain. }\end{array}$ & {$[80]$} \\
\hline $\begin{array}{l}\text { Cacciotta } \\
\text { cheese }\end{array}$ & Lactobacillus paracasei $\mathrm{A} 13$ & $50 \mathrm{MPa}$ & $\begin{array}{l}\text { Increase in quality and decrease in } \\
\text { cheese maturation time. }\end{array}$ & [81] \\
\hline $\begin{array}{l}\text { Mandarin } \\
\text { juice }\end{array}$ & L. salivarius spp. Salivarius & $\begin{array}{l}0,20 \text { and } 100 \\
\mathrm{MPa}\end{array}$ & $\begin{array}{l}\text { Improvement of cellular } \\
\text { hydrophobicity. }\end{array}$ & {$[66]$} \\
\hline $\begin{array}{l}\text { Clementine } \\
\text { juice }\end{array}$ & L. salivarius spp. Salivarius & $\begin{array}{l}25,50,100 \text { and } \\
150 \mathrm{MPa}\end{array}$ & $\begin{array}{l}\text { Improvement of the antioxidant } \\
\text { properties of the juice. }\end{array}$ & [82] \\
\hline $\begin{array}{l}\text { Fresh Culture } \\
(1 \% v / v)\end{array}$ & Lactobacillus paracasei A13 & $\begin{array}{l}\text { 50, 150, } 200 \\
\mathrm{MPa}\end{array}$ & $\begin{array}{l}\text { Increase in the unsaturation in } \\
\text { membrane fatty acids. }\end{array}$ & [83] \\
\hline
\end{tabular}

(-) indicates that the component has not been included in a food matrix

Siroli et al. [83] reported that the main regulatory mechanism that probiotic lactobacilli adopt to counteract pressure stress is the modification of the composition of membrane fatty acids. Specifically, they observed an increase in unsaturated fatty acids when $\mathrm{HPH}$ at 100 and $150 \mathrm{MPa}$ was applied to Lactobacillus paracasei A13. Considering that the increase of the unsaturation level is a key mechanism to compensate for the oxidative damages induced by physico-chemical stressors in microbial cells, they concluded that HPH at sublethal pressures is useful to improve the activity of some Lactobacillus species. 
Lanciotti et al. [84] studied the effect of HPH between $50 \mathrm{MPa}$ and 100 MPa on the fermentation kinetics, metabolic profile and enzymatic activity of four species of Lactobacilli involved in dairy product fermentation and ripening. Although the results varied according to the species, they documented no significant effect on cell viability, an increased proteolytic activity and positive changes in fermentation dynamics. The resistance to simulated gastric conditions, hydrophobicity and auto-aggregation capacity were strain-dependent for L. acidophilus Dru and L. paracasei A13 when subjected to $\mathrm{HPH}$ at $50 \mathrm{MPa}$. $\mathrm{HPH}$ increased the three properties for $L$. paracasei $\mathrm{A} 13$ but reduced them for L. acidophilus Dru; the authors attributed this to the compositional and structural differences in the cellular outer structures, thus suggesting that the HPH effects on macromolecules and their interactions with the gut immune cells play a key role in the probiotic effect. The same authors noted that HPH treated L. paracasei cells modified their interaction with the small intestine of mice, inducing a higher IgA response compared to untreated L. paracasei cells [12,79]. Betoret et al. [66] demonstrated an improvement in the hydrophobicity of Lactobacillus salivarius spp. salivarius added to mandarin juice with trehalose when $\mathrm{HPH}$ at 0, 20 and $100 \mathrm{MPa}$ was applied.

\section{Conclusions}

Although in the beginning, the application of high homogenizing pressures was aimed at more efficient homogenizing and increasing the stability of emulsions such as milk, advances in valve design have allowed for an increase in working pressure extending the scope of possible applications.

In the last decade, the number of research works related to the implementation of $\mathrm{HPH}$-for extracting bioactive components from agri-food wastes, to improve the bioavailability and probiotic properties of bioactive components and microorganisms, and also as an encapsulation techniquehas grown by more than $80 \%$. At the same time, progress has been made in the application of $\mathrm{HPH}$ to reduce the microbial load or modulate the activity of some enzymes.

The general mechanisms responsible for the effect of HPH are known, but the final effect is largely conditioned by the type of valve, pressure applied, number of passes, the nature of the components and macromolecules, and 
the food matrix. For this reason, research is needed for each specific application.

Results published in the last decade have shown HPH to be a nonthermal technology which is able to accomplish the food industry's objectives of quality and safety, functionality and sustainability.

Author Contributions: Conceptualization, N.B. and E.B.; methodology and search, J.M., L.I.H. and N.B.; writing-original draft preparation, J.M. and N.B.; writingreview and editing, E.B., L.S. and C.B.; funding acquisition, N.B. All authors have read and agreed to the published version of the manuscript.

Funding: Please add: This research and APC were funded by Generalitat Valenciana, Project AICO/2017/'049-

Acknowledgments: The authors thank the research project "Fortalecimiento de los Encadenamientos Productivos de las Subregiones del Chocó" BPIN 2013000100284 Tecnológica del Chocó (in Spanish) by financial support to Leidy Indira HinestrozaCórdoba.

\section{References}

1. Augusto, P.E.; Tribst, A.A.; Cristianini, M. High Hydrostatic Pressure and High-Pressure Homogenization Processing of Fruit Juices. In Fruit Juices; Elsevier BV: Amsterdam, The Netherlands, 2018; pp. 393-421.

2. Koutchma, T. Fundamentals of HPP Technology. In Adapting High Hydrostatic Pressure for Food Processing Operations; Elsevier BV: Amsterdam, The Netherlands, 2014; pp. 5-10.

3. Osorio-Arias, J.C.; Vega-Castro, O.; Martínez-Monteagudo, S.I. Fundamentals of HighPressure Homogenization of Foods. In Reference Module in Food Science; Elsevier BV: Amsterdam, The Netherlands, 2020.

4. Bevilacqua, A.; Campaniello, D.; Speranza, B.; Altieri, C.; Sinigaglia, M.; Corbo, M.R. Two Nonthermal Technologies for Food Safety and Quality-Ultrasound and HighPressure Homogenization: Effects on Microorganisms, Advances, and Possibilities: A Review. J. Food Prot. 2019, 82, 2049-2064.

5. Picart-Palmade, L.; Cunault, C.; Chevalier-Lucia, D.; Belleville, M.-P.; Marchesseau, S. Potentialities and Limits of Some Non-thermal Technologies to Improve Sustainability of Food Processing. Front. Nutr. 2019, 5, 130.

6. McClatchie, J.M. The Borden Company. Valve Homog. Dev. 1930, 28, 131-134.

7. Pandolfe, W.D. Development of the New Gaulin Micro-Gap ${ }^{\mathrm{TM}}$ Homogenizing Valve. J. Dairy Sci. 1982, 65, 2035-2044.

8. Patrignani, F.; Siroli, L.; Braschi, G.; Lanciotti, R. Combined use of natural antimicrobial based nanoemulsions and ultra-high-pressure homogenization to increase safety and shelf-life of apple juice. Food Control. 2020, 111, 107051

9. Balasubramaniam, V.M.; Barbosa-Cánovas, G.; Lelieveld, H. High Pressure Processing of Food-Principles, Technology and Application; Springer; Berlin/Heidelberg, Germany, 2016; ISBN 978-1-4939-3233-7. 
10. Tribst, A.A.L.; Franchi, M.A.; de Massaguer, P.R.; Cristianini, M. Quality of mango nectar processed by high-pressure homogenization with optimized heat treatment. J. Food Sci. 2011, 76, M106-M110.

11. Calligaris, S.; Foschia, M.; Bartolomeoli, I.; Maifreni, M.; Manzocco, L. Study on the applicability of high-pressure homogenization to produce banana juices. LWT 2012, 45, 117-121

12. Tabanelli, G.; Patrignani, F.; Vinderola, G.; Reinheimer, J.; Gardini, F.; Lanciotti, R. Effect of sub-lethal high-pressure homogenization treatments on the in vitro functional and biological properties of lactic acid bacteria. LWT 2013, 53, 580-586.

13. Guan, Y.; Zhou, L.; Bi, J.; Yi, J.; Liu, X.; Chen, Q.; Wu, X.; Zhou, M. Change of microbial and quality attributes of mango juice treated by high pressure homogenization combined with moderate inlet temperatures during storage. Innov. Food Sci. Emerg. Technol. 2016, 36, 320-329

14. Yu, Y.; Wu, J.; Xu, Y.; Xiao, G.; Zou, B. Effect of High-Pressure Homogenization and Dimethyl Dicarbonate (DMDC) on Microbial and Physicochemical Qualities of Mulberry Juice. J. Food Sci. 2016, 81, M702-M708.

15. Xia, X.; Dai, Y.; Wu, H.; Liu, X.; Wang, Y.; Cao, J.; Zhou, J. Effects of pressure and multiple passes on the physicochemical and microbial characteristics of lupin-based beverage treated with high-pressure homogenization. J. Food Process. Preserv. 2019, 43, e13912.

16. Benjamin, O.; Gamrasni, D. Microbial, nutritional, and organoleptic quality of pomegranate juice following high-pressure homogenization and low-temperature pasteurization. J. Food Sci. 2020, 85, 592-599.

17. Pinho, C.R.; Franchi, M.A.; Tribst, A.A.; Cristianini, M. Effect of Ultra High-Pressure Homogenization on Alkaline Phosphatase and Lactoperoxidase Activity in Raw Skim Milk. Procedia Food Sci. 2011, 1, 874-878.

18. Amador-Espejo, G.G.; Hernández-Herrero, M.M.; Juan, B.; Trujillo, A.-J. Inactivation of Bacillus spores inoculated in milk by Ultra High-Pressure Homogenization. Food Microbiol. 2014, 44, 204-210.

19. Mercan, E.; Sert, D.; Akın, N. Determination of powder flow properties of skim milk powder produced from high-pressure homogenization treated milk concentrates during storage. LWT 2018, 97, 279-288.

20. Valencia-Flores, D.C.; Hernández-Herrero, M.M.; Guamis, B.; Ferragut, V. Comparing the Effects of Ultra-High-Pressure Homogenization and Conventional Thermal Treatments on the Microbiological, Physical, and Chemical Quality of Almond Beverages. J. Food Sci. 2013, 78, E199-E205.

21. Bevilacqua, A.; Casanova, F.P.; Petruzzi, L.; Sinigaglia, M.; Corbo, M. Using physical approaches for the attenuation of lactic acid bacteria in an organic rice beverage. Food Microbiol. 2016, 53, 1-8.

22. Codina-Torrella, I.; Guamis, B.; Zamora, A.; Quevedo, J.; Trujillo, A.-J. Microbiological stabilization of tiger nuts' milk beverage using ultra-high-pressure homogenization. $A$ preliminary study on microbial shelf-life extension. Food Microbiol. 2018, 69, 143150.

23. Franchi, M.A.; Tribst, A.A.L.; Cristianini, M. Inactivation of Lactobacillus brevis in Beer Utilizing a Combination of High-Pressure Homogenization and Lysozyme Treatment. J. Inst. Brew. 2011, 117, 634-638. 
24. Franchi, M.A.; Tribst, A.A.L.; Cristianini, M. High-pressure homogenization: A nonthermal process applied for inactivation of spoilage microorganisms in beer. J. Inst. Brew. 2013, 119, 237-241.

25. Comuzzo, P.; Calligaris, S.; lacumin, L.; Ginaldi, F.; Paz, A.E.P.; Zironi, R. Potential of high-pressure homogenization to induce autolysis of wine yeasts. Food Chem. 2015, 185, 340-348.

26. Capra, M.L.; Patrignani, F.; Quiberoni, A.D.L.; Reinheimer, J.A.; Lanciotti, R.; Guerzoni, M.E. Effect of high-pressure homogenization on lactic acid bacteria phages and probiotic bacteria phages. Int. Dairy J. 2009, 19, 336-341.

27. Patrignani, F.; Vannini, L.; Kamdem, S.L.S.; Lanciotti, R.; Guerzoni, M.E. Potentialities of High-Pressure Homogenization to Inactivate Zygosaccharomyces bailii in Fruit Juices. J. Food Sci. 2010, 75, M116-M120, doi:10.1111/j.1750-3841.2009.01508.x.

28. Aguilar, J.G.D.S.; Cristianini, M.; Sato, H.H.; dos Santos, J.G. Modification of enzymes by use of high-pressure homogenization. Food Res. Int. 2018, 109, 120-125.

29. Bot, F.; Calligaris, S.; Cortella, G.; Plazzotta, S.; Nocera, F.; Anese, M. Study on high pressure homogenization and high-power ultrasound effectiveness in inhibiting polyphenoloxidase activity in apple juice. J. Food Eng. 2018, 221, 70-76

30. Plazzotta, S.; Manzocco, L. High-pressure homogenisation combined with blanching to turn lettuce waste into a physically stable juice. Innov. Food Sci. Emerg. Technol. 2019, 52, 136-144.

31. Tribst, A.A.L.; Cristianini, M. High pressure homogenization of a fungi $\alpha$-amylase. Innov. Food Sci. Emerg. Technol. 2012, 13, 107-111.

32. de Oliveira, M.M.; Júnior, B.R.D.C.L.; Tribst, A.A.L.; Cristianini, M. Use of high-pressure homogenization to reduce milk proteolysis caused by Pseudomonas fluorescens protease. LWT 2018, 92, 272-275.

33. Tribst, A.A.L.; Cristianini, M. Changes in commercial glucose oxidase activity by high pressure homogenization. Innov. Food Sci. Emerg. Technol. 2012, 16, 355-360.

34. Dong, X.; Zhao, M.; Shi, J.; Yang, B.; Li, J.; Luo, D.; Jiang, G.; Jiang, Y. Effects of combined high-pressure homogenization and enzymatic treatment on extraction yield, hydrolysis and function properties of peanut proteins. Innov. Food Sci. Emerg. Technol. 2011, 12, 478-483.

35. Tribst, A.A.L.; Ribeiro, L.R.; Cristianini, M. Comparison of the effects of high-pressure homogenization and high pressure processing on the enzyme activity and antimicrobial profile of lysozyme. Innov. Food Sci. Emerg. Technol. 2017, 43, 60-67.

36. Lucci, L.; Patrignani, F.; Vallicelli, M.; Guerzoni, M.E.; Lanciotti, R. Effects of highpressure homogenization on the activity of lysozyme and lactoferrin against Listeria monocytogenes. Food Control. 2007, 18, 558-565.

37. Zhu, X.; Cheng, Y.; Chen, P.; Peng, P.; Liu, S.; Li, D.; Ruan, R. Effect of alkaline and highpressure homogenization on the extraction of phenolic acids from potato peels. Innov. Food Sci. Emerg. Technol. 2016, 37, 91-97.

38. Flôres, S.H.; Rios, A.D.O.; lahnke, A.O.; de Campo, C.; Vargas, C.G.; Santos, C.D.; Caetano, K.D.S.; Stoll, L.; Crizel, T.D.M. Films for Food from Ingredient Waste. In Reference Module in Food Science; Elsevier BV: Amsterdam, The Netherlands, 2017.

39. Xie, F.; Zhang, W.; Lan, X.; Gong, S.; Wu, J.; Wang, Z. Effects of high hydrostatic pressure and high-pressure homogenization processing on characteristics of potato peel waste pectin. Carbohydr. Polym. 2018, 196, 474-482. 
40. Fayaz, G.; Plazzotta, S.; Calligaris, S.; Manzocco, L.; Nicoli, M.C. Impact of highpressure homogenization on physical properties, extraction yield and biopolymer structure of soybean okara. LWT 2019, 113, 108324.

41. Wang, W.; Zhang, K.; Li, C.; Cheng, S.; Zhou, J.; Wu, Z. A novel biodegradable film from edible mushroom (F. velutipes) by product: Microstructure, mechanical and barrier properties associated with the fiber morphology. Innov. Food Sci. Emerg. Technol. 2018, 47, 153-160.

42. Wu, H.; Xiao, D.; Lu, J.; Jiao, C.; Li, S.; Lei, Y.; Liu, D.; Wang, J.; Zhang, Z.; Liu, Y.; et al. Effect of high-pressure homogenization on microstructure and properties of pomelo peel flour film-forming dispersions and their resultant films. Food Hydrocoll. 2020, 102, 105628.

43. Sarıcaoğlu, F.T.; Atalar, I.; Yilmaz, V.A.; Odabas, H.I.; Gul, O. Application of multi pass high pressure homogenization to improve stability, physical and bioactive properties of rosehip (Rosa canina L.) nectar. Food Chem. 2019, 282, 67-75.

44. Hua, X.; Xu, S.; Wang, M.; Chen, Y.; Yang, H.; Yang, R. Effects of high-speed homogenization and high-pressure homogenization on structure of tomato residue fibers. Food Chem. 2017, 232, 443-449.

45. Xu, H.; Jiao, Q.; Yuan, F.; Gao, Y. In vitro binding capacities and physicochemical properties of soluble fiber prepared by microfluidization pretreatment and cellulase hydrolysis of peach pomace. LWT 2015, 63, 677-684.

46. Willemsen, K.L.; Panozzo, A.; Moelants, K.; de Bon, S.J.; Desmet, C.; Cardinaels, R.; Moldenaers, P.; Wallecan, J.; Hendrickx, M. Physico-chemical and viscoelastic properties of high pressure homogenized lemon peel fiber fraction suspensions obtained after sequential pectin extraction. Food Hydrocoll. 2017, 72, 358-371.

47. Plazzotta, S.; Manzocco, L. Effect of ultrasounds and high-pressure homogenization on the extraction of antioxidant polyphenols from lettuce waste. Innov. Food Sci. Emerg. Technol. 2018, 50, 11-19.

48. Huang, X.; Tu, Z.; Xiao, H.; Li, Z.; Zhang, Q.; Wang, H.; Hu, Y.; Zhang, L. Dynamic high pressure microfluidization-assisted extraction and antioxidant activities of sweet potato (Ipomoea batatas L.) leaves flavonoid. Food Bioprod. Process. 2013, 91, 1-6.

49. Rommi, K.; Rahikainen, J.; Vartiainen, J.; Holopainen, U.; Lahtinen, P.; Honkapää, K.; Lantto, R. Potato peeling costreams as raw materials for biopolymer film preparation. J. Appl. Polym. Sci. 2015, 133.

50. Xie, Y.; Ho, S.-H.; Chen, C.-N.N.; Chen, C.-Y.; Jing, K.; Ng, I.-S.; Chen, J.; Chang, J.-S.; Lu, Y. Disruption of thermo-tolerant Desmodesmus sp. F51 in high pressure homogenization as a prelude to carotenoids extraction. Biochem. Eng. J. 2016, 109, 243-251.

51. Zhu, X.; Lundberg, B.; Cheng, Y.; Shan, L.; Xing, J.-J.; Peng, P.; Chen, P.; Huang, X.; Li, D.; Ruan, R. Effect of high-pressure homogenization on the flow properties of citrus peel fibers. J. Food Process. Eng. 2017, 41, e12659, doi:10.1111/jfpe.12659.

52. Preece, K.; Hooshyar, N.; Zuidam, N. Whole soybean protein extraction processes: A review. Innov. Food Sci. Emerg. Technol. 2017, 43, 163-172.

53. Sarıcaoğlu, F.T.; Gul, O.; Besir, A.; Atalar, I. Effect of high-pressure homogenization $(\mathrm{HPH})$ on functional and rheological properties of hazelnut meal proteins obtained from hazelnut oil industry by-products. J. Food Eng. 2018, 233, 98-108. 
54. Zhang, W.; Xie, F.; Lan, X.; Gong, S.; Wang, Z. Characteristics of pectin from black cherry tomato waste modified by dynamic high-pressure microfluidization. J. Food Eng. 2018, 216, 90-97

55. Otoni, C.G.; Lodi, B.D.; Lorevice, M.V.; Leitão, R.C.; Ferreira, M.D.; de Moura, M.R.; Mattoso, L.H. Optimized and scaled-up production of cellulose-reinforced biodegradable composite films made up of carrot processing waste. Ind. Crop. Prod. 2018, 121, 66-72.

56. Xing, J.-J.; Cheng, Y.; Chen, P.; Shan, L.; Ruan, R.; Li, D.; Wang, L. Effect of high-pressure homogenization on the extraction of sulforaphane from broccoli (Brassica oleracea) seeds. Powder Technol. 2019, 358, 103-109.

57. Mustafa, W.; Pataro, G.; Ferrari, G.; Donsì, F. Novel approaches to oil structuring via the addition of high-pressure homogenized agri-food residues and water forming capillary bridges. J. Food Eng. 2018, 236, 9-18.

58. Griffin, S.; Sarfraz, M.; Farida, V.; Nasim, M.J.; Ebokaiwe, A.P.; Keck, C.M.; Jacob, C. No time to waste organic waste: Nanosizing converts remains of food processing into refined materials. J. Environ. Manag. 2018, 210, 114-121.

59. Ilyas, R.A.; Sapuan, S.; Ishak, M.; Zainudin, E.S. Sugar palm nanofibrillated cellulose (Arenga pinnata (Wurmb.) Merr): Effect of cycles on their yield, physic-chemical, morphological, and thermal behavior. Int. J. Boil. Macromol. 2019, 123, 379-388.

60. Jurić, S.; Ferrari, G.; Imhof, A.; Donsi', F. High-pressure homogenization treatment to recover bioactive compounds from tomato peels. J. Food Eng. 2019, 262, 170-180.

61. Zhang, Y.; Shi, R.; Xu, Y.; Chen, M.; Zhang, J.; Gao, Q.; Li, J. Developing a stable highperformance soybean meal-based adhesive using a simple high-pressure homogenization technology. J. Clean. Prod. 2020, 256, 120336.

62. Zhou, L. High-Pressure Homogenization Effect on the Stability and Bioaccessibility of Bioactive Phytochemicals and Vitamins in the Food Matrix. In Reference Module in Food Science; Elsevier BV: Amsterdam, The Netherlands, 2019.

63. Sentandreu, E.; Stinco, C.M.; Vicario, I.M.; Mapelli-Brahm, P.; Navarro, J.L.; MeléndezMartínez, A.J. High-pressure homogenization as compared to pasteurization as a sustainable approach to obtain mandarin juices with improved bioaccessibility of carotenoids and flavonoids. J. Clean. Prod. 2020, 262, 121325.

64. Quan, W.; Tao, Y.; Qie, X.; Zeng, M.; Qin, F.; Chen, J.; He, Z. Effects of high-pressure homogenization, thermal processing, and milk matrix on the in vitro bioaccessibility of phenolic compounds in pomelo and kiwi juices. J. Funct. Foods 2020, 64, 103633.

65. Alongi, M.; Calligaris, S.; Anese, M. Fat concentration and high-pressure homogenization affect chlorogenic acid bioaccessibility and $\alpha$-glucosidase inhibitory capacity of milk-based coffee beverages. J. Funct. Foods 2019, 58, 130-137.

66. Betoret, E.; Jiménez, L.C.; Patrignani, F.; Lanciotti, R.; Rosa, M.D. Effect of highpressure processing and trehalose addition on functional properties of mandarin juice enriched with probiotic microorganisms. LWT 2017, 85, 418-422.

67. Munekata, P.E.S.; Domínguez, R.; Budaraju, S.; Roselló-Soto, E.; Barba, F.J.; Mallikarjunan, P.K.; Roohinejad, S.; Lorenzo, J.M. Effect of Innovative Food Processing Technologies on the Physicochemical and Nutritional Properties and Quality of NonDairy Plant-Based Beverages. Foods 2020, 9, 288.

68. Toro-Funes, N.; Bosch-Fusté, J.; Veciana-Nogués, M.T.; Vidal-Carou, M.C. Influence of Ultra-High-Pressure Homogenization Treatment on the Phytosterols, Tocopherols, and Polyamines of Almond Beverage. J. Agric. Food Chem. 2014, 62, 9539-9543.

69. Atalar, I. Functional kefir production from high pressure homogenized hazelnut milk. LWT 2019, 107, 256-263.

70. Kapoor, R.; Pathak, S.; Najmi, A.K.; Aeri, V.; Panda, B.P. Processing of soy functional food using high pressure homogenization for improved nutritional and therapeutic benefits. Innov. Food Sci. Emerg. Technol. 2014, 26, 490-497. 
71. Jiang, T.; Liao, W.; Charcosset, C. Recent advances in encapsulation of curcumin in nanoemulsions: A review of encapsulation technologies, bioaccessibility and applications. Food Res. Int. 2020, 132, 109035.

72. Frank, K.; Köhler, K.; Karbstein, H.P. Stability of anthocyanins in high pressure homogenisation. Food Chem. 2012, 130, 716-719.

73. Patrignani, F.; Siroli, L.; Serrazanetti, D.I.; Braschi, G.; Betoret, E.; Reinheimer, J.A.; Lanciotti, R. Microencapsulation of functional strains by high pressure homogenization for a potential use in fermented milk. Food Res. Int. 2017, 97, 250257.

74. Jiménez, L.C.; Ester, B.; Betoret, N.; Patrignani, F.; Barrera, C.; Seguí, L.; Lanciotti, R.; Rosa, M.D. High pressures homogenization (HPH) to microencapsulate $L$. salivarius spp. salivarius in mandarin juice. Probiotic survival and in vitro digestion. J. Food Eng. 2019, 240, 43-48.

75. Bamba, B.S.B.; Shi, J.; Tranchant, C.C.; Xue, S.J.; Forney, C.; Lim, L.-T.; Xu, W.; Xu, G. Coencapsulation of Polyphenols and Anthocyanins from Blueberry Pomace by Double Emulsion Stabilized by Whey Proteins: Effect of Homogenization Parameters. Molecules 2018, 23, 2525.

76. Tatar, B.C.; Sumnu, G.; Oztop, M. Microcapsule characterization of phenolic powder obtained from strawberry pomace. J. Food Process. Preserv. 2019, 43, e13892.

77. Ester, B.; Noelia, B.; Laura, C.-J.; Patrignani, F.; Cristina, B.; Lanciotti, R.; Marco, D.R. Probiotic survival and in vitro digestion of $L$. salivarius spp. salivarius encapsulated by high homogenization pressures and incorporated into a fruit matrix. LWT 2019, 111, 883-888.

78. Muramalla, T.; Aryana, K. Some low homogenization pressures improve certain probiotic characteristics of yogurt culture bacteria and Lactobacillus acidophilus LA-K. J. Dairy Sci. 2011, 94, 3725-3738.

79. Tabanelli, G.; Burns, P.; Patrignani, F.; Gardini, F.; Lanciotti, R.; Reinheimer, J.; Vinderola, G. Effect of a non-lethal High-Pressure Homogenization treatment on the in vivo response of probiotic lactobacilli. Food Microbiol. 2012, 32, 302-307.

80. Patrignani, F.; Serrazanetti, D.I.; Mathara, J.M.; Siroli, L.; Gardini, F.; Holzapfel, W.; Lanciotti, R. Use of homogenisation pressure to improve quality and functionality of probiotic fermented milks containing Lactobacillus rhamnosus BFE 5264. Int. J. Dairy Technol. 2015, 69, 262-271.

81. Burns, P.; Patrignani, F.; Tabanelli, G.; Vinderola, G.C.; Siroli, L.; Reinheimer, J.A.; Gardini, F.; Lanciotti, R. Potential of high pressure homogenisation on probiotic Caciotta cheese quality and functionality. J. Funct. Foods 2015, 13, 126-136.

82. Barrera, C.; Burca, C.; Betoret, E.; García-Hernández, J.; Hernández, M.; Betoret, N. Improving antioxidant properties and probiotic effect of clementine juice inoculated with Lactobacillus salivarius spp. salivarius (CECT 4063) by trehalose addition and/or sublethal homogenisation. Int. J. Food Sci. Technol. 2019, 54, 2109-2122.

83. Siroli, L.; Braschi, G.; Rossi, S.; Gottardi, D.; Patrignani, F.; Lanciotti, R. Lactobacillus paracasei A13 and High-Pressure Homogenization Stress Response. Microorganisms 2020, 8, 439.

84. Lanciotti, R.; Patrignani, F.; lucci, L.; Saracino, P.; E Guerzoni, M. Potential of highpressure homogenization in the control and enhancement of proteolytic and fermentative activities of some Lactobacillus species. Food Chem. 2007, 102, 542550 . 


\title{
Potential Use of Vacuum Impregnation and High-Pressure Homogenization to Obtain Functional Products from Lulo Fruit (Solanum quitoense Lam.)
}

\author{
Leidy Indira Hinestroza-Córdoba ${ }^{1,2}$, Cristina Barrera ${ }^{1}$, Lucia Seguí ${ }^{1}$, and Noelia \\ Betoret ${ }^{1}$.
}

1 Grupo de Valoración y Aprovechamiento de la Biodiversidad, Universidad Tecnológica del Chocó, AA.292, Calle 22 No. 18B-10, CP. 270002, Quibdó, Chocó, Colombia; leihicor@doctor.upv.es

2 Institute of Food Engineering for Development, Universitat Politècnica de València, CP 46022 València, Spain; ester_betoret@hotmail.com (E.B.); lusegil@upvnet.upv.es (L.S.); mcbarpu@tal.upv.es (C.B.)

* Correspondence: noebeval@tal.upv.es; Tel.: +34-963-877-000 (ext. 73658)

Foods 2021, 10(4), 817

\begin{abstract}
Lulo (Solanum quitoense Lam.) is a Colombian fruit that is mostly used in the preparation of homemade juice as well as natural remedy for hypertension. The aim of this study was to deter-mine physicochemical and antioxidant properties (antioxidant capacity, total phenols, flavonoids and spermidine content, and polyphenolic compounds profile by liquid chromatography-mass spectrometry (LC-MS)) of the lulo fruit and its juice. Additionally, vacuum impregnation (VI) properties of the fruit and the effect of high homogenization pressure $(50,100$, and $150 \mathrm{MPa})$ on the juice properties were studied. The results revealed a good availability and impregnation capacity of the pores in fruits with similar maturity index. The main differences observed between the juice and fruit derive from removing solids and bioactive components in the filtering operation. However, the effect of high-pressure homogenization (HPH) on particle size and bioactive compounds increases the antiradical capacity of the juice and the diversity in polyphenolics when increasing the homogenization pressure.
\end{abstract}

Keywords: LC-mass spectrometry; antioxidant capacity; vacuum impregnation; polyphenolic profile; lulo fruit juice; spermidine. 


\section{Introduction}

Having great fruit diversity, Colombia is worldwide considered one of the main producers of tropical fresh fruit with advantageous possibilities for the development of healthy food products from regional wild species [1].

One of Colombia's territorial departments with great natural wealth is Chocó, which is characterized by its mega diverse and complex ecosystems with high primary pro-duction and little agrifood system transformation. On the other hand, according to a health situation analysis carried out and published by the Ministry of Health and Social Protection (MINSALUD) in 2018 [2], around $25.7 \%$ of the adult population in this region suffers from hypertension problems. According to the World Health Organization (WHO), noncommunicable diseases such as cancer, diabetes and hypertension are the main death causes worldwide [3]. Among them, hypertension has become the leading cause of death not only in Colombia but around the world, where it has reached up to 1.13 million sick people. In this context, the development of functional foods to prevent cardiovascular risk from highly consumed local fruits is a challenge.

Lulo (Solanum quitoense Lam.) is one of the most important tropical fruits in Colombia. Known as naranjilla in Ecuador and as lulum in Peru, this crop from the Solanaceae family is grown in Colombia, Ecuador, Peru, Venezuela, Guatemala, Mexico, Costa Rica, Dominican Republic, and Panama. The plant produces a spherical fruit with a diameter that varies between 3 and $8 \mathrm{~cm} \mathrm{[4].} \mathrm{In} \mathrm{the} \mathrm{last} \mathrm{years,} \mathrm{the} \mathrm{lulo} \mathrm{fruit} \mathrm{has} \mathrm{raised} \mathrm{considerable} \mathrm{interest} \mathrm{in} \mathrm{the}$ global market due to its organoleptic characteristics, pleasant aroma, and acidic and refreshing taste [5]. Consequently, its exportation has undergone a remarkable increase, particularly reaching the United States and Europe. The fruit has considerable nutritional potential due to its high content of vitamins such as thiamin, riboflavin, vitamin A, proteins, minerals, and spermidine [6]. A recent study has demonstrated the potential antihypertensive use of lulo [7]. For the first time, these authors found $\mathrm{N}^{1}, \mathrm{~N}^{4}, \mathrm{~N}^{8}$-tris (Dihydrocafeoil) spermidine and $\mathrm{N}^{1}, \mathrm{~N}^{8}$-bis-(Dihydrocafeoil) spermidine to be bitter bioactive amines in lulo fruit samples. These compounds confer some functional characteristics to lulo for the control of hypertension.

Technological transformation processes are needed to produce innovative fruit de-rivatives with a long shelf life and, as much as possible, 
preserved functional attributes and acceptable physical and sensorial characteristics. In this sense, some nonthermal technologies allow for the improvement or maintenance of relevant properties. Compared to traditional heat treatments, the application of high- and/or moderate- pressure homogenization (HPH) to fruit juices has been shown to be less destructive for food compounds of low molecular weight. Likewise, this result may be related to sensory and nutritional qualities and to the sufficient inactivation of different microorganisms. Moreover, it can improve the efficiency and performance of other processes when applied as pretreatment $[8,9]$.

Additionally, food engineering operations like vacuum impregnation (VI) allow for the incorporating of physiologically active compounds to fruit matrices; the structure of which performs as a natural protection, thus resulting in fresh functional foods $[10,11]$. Fruit juices with improved properties have been incorporated into adequate fruit matrices, leading to functional foods with better composition and high potential to soften some health problems [12].

Due to the valuable and characteristic aroma of lulo fruit and its richness in antioxidant components, some studies regarding volatile profile, antioxidant capacity, and composition in carotenoids, polyphenols, or other micronutrients have been done. In addition, it is possible to find some works in the literature focused on pulp-drying to obtain a powder for industrial use. However, as far as the authors know, no work has been carried out determining the possibilities of using the fruit in VI treatments or analyzing the effect of HPH on the physicochemical and antioxidant properties of juice.

Considering everything mentioned above, it was considered relevant to study physicochemical and antioxidant properties (antioxidant capacity, total phenols, flavonoids and spermidine contents, and polyphenolic compounds profile) of the lulo fruit and its juice. Additionally, VI properties of the fruit and the effect of $\mathrm{HPH}(50,100$, and $150 \mathrm{MPa}$ and one pass) on the lulo juice properties were studied too. The end goal is to provide knowledge contributing to the use of the indigenous agrifood resources of the region of Chocó (Colombia) in order to improve the health of its population. 


\section{Materials and methods}

\subsection{Food materials and sample preparation}

Colombian fresh lulo fruits (Solanum quitoense Lam.) were purchased at the Central Market of Valencia (Spain) and stored at $4{ }^{\circ} \mathrm{C}$ until processing.

The whole fruits were processed as follows for their analysis: after removing the peduncle, they were washed and cut into pieces, which were crushed in a mortar. This whole crushed fruit is hereafter called "fruit".

The procedure for obtaining the lulo juice was as follows: after removing the pe-duncle, the whole fresh fruit was washed and blended (Phillips Advance Collection Standmixer, $800 \mathrm{~W}, 2 \mathrm{~L}$ ) for $10 \mathrm{~min}$. Then, the blend was filtered and sieved with a $500 \mu \mathrm{m}$ stainless-steel mesh sift (200/50, CISA). The filtered liquid thus obtained is hereafter called "juice".

The sample preparation for VI experiments was as follows: the fruit was washed and cut transversally into $5 \mathrm{~mm}$ thickness and $64 \mathrm{~mm}$ diameter slices (FAGOR CF-150 slicer). The fruit skin was not removed, so as to prevent any absorption of materials through the lateral surface of the slices, which allowed assuming unidirectional matter flow. The impregnation experiments were carried out on three lulo fruit batches at a very similar ripeness stage, and three samples per batch were characterized.

Figure 1 summarizes in a flow chart the sample preparation and treatments.

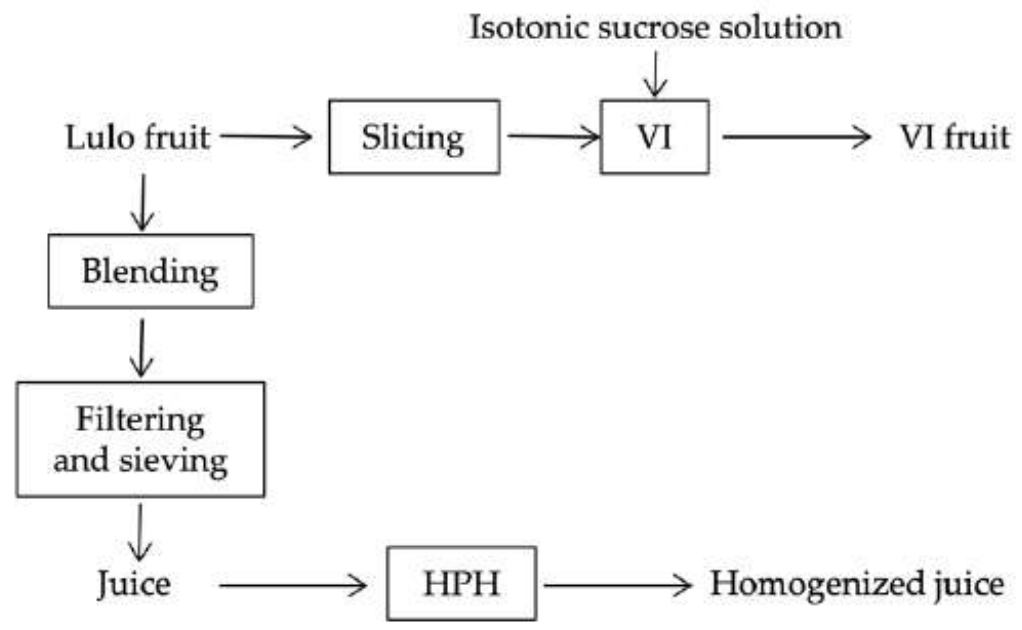

Figure 1. Flow chart summarizing sample preparation and treatments. 


\subsection{HPH treatment}

Juice samples were homogenized with one pass (Gea Niro Soavi-Panda Plus 2000 homogenizer, Parma, Italy) at 50, 100, and $150 \mathrm{MPa}$. Homogenized and nonhomogenized juices were refrigerated at $4{ }^{\circ} \mathrm{C}$ under aseptic conditions until later analysis.

\subsection{VI experiments}

The VI experiments were carried at a pilot plant scale in the Institute of Food Engineering for Development at Universitat Politècnica de València (Spain). The equipment used was described by Fito et al. [13]. In all trials, the sliced fruit samples were immersed in isotonic sucrose aqueous solutions (aw $=0.994 \pm 0.003$ ), and a vacuum pressure of 50 mbar was applied for $10 \mathrm{~min}$. Subsequently, atmospheric pressure was restored, keeping the fruit slices immersed in the impregnation liquid for $10 \mathrm{~min}$ more. The impregnation parameters allow us to quantify the volumetric fraction of liquid incorporated into the porous structure and the volumetric deformation of the sample after the vacuum stage $\left(X 1\right.$ and $\left.\gamma_{1}\right)$ and at the end of the process ( $X$ and $\gamma$ ). The effective porosity $\left(\varepsilon_{\mathrm{e}}\right)$ provides information on the volumetric fraction of pores that are filled during the $\mathrm{VI}$ experiments. All the parameters were calculated using the model equations proposed by Fito et al. [14].

\subsection{Physicochemical characterization}

In fruit, the moisture content was quantified by vacuum drying at 60 ${ }^{\circ} \mathrm{C}$ until constant weight [15]. Water activity was measured using a dew point hydrometer (DECAGÓN Aqualab CX-2, Washington, USA \pm 0.003 ). Brix were determined in a refractometer (ABBE ATAGO BT, NAR T3, Tokyo, Japan) at 20 ${ }^{\circ} \mathrm{C}$. $\mathrm{pH}$ values were measured with a potentiometer (Mettler Toledo Inlab, Schwerzenbach, Switzerland) at $20{ }^{\circ} \mathrm{C}$. The apparent density was obtained through the volume displacement method, using a solids pycnometer and toluene as reference liquid.

In homogenized and nonhomogenized juice, density was determined with a liquid's pycnometer. Particle size distribution was determined using a Malvern Mastersize 2000 system (Malvern Instruments Limited, Worcesterhire, UK) equipped with a blue light source (470 $\mathrm{nm}$ wavelength; 0.02-200 micron measuring range). A small amount of sample was diluted in 
deionized water in the diffractometer cell under moderate agitation until it reached $8-9 \%$ darkness. The refractive index values of the juice (cloud) and the dispersant (water) were 1.5 and 1.33, respectively. These measurements were taken using a short-wavelength blue light source in conjunction with forward and backscatter detection to enhance sizing performance in the 0.01$1000 \mu \mathrm{m}$ range. The particle size distribution of the juice was characterized by percentages in volume $(D[4,3])$ and in area $(D[3,2])$ based diameters, and by percentiles $\mathrm{d} 10, \mathrm{~d} 50$, and $\mathrm{d} 90$, which represent the characteristic diameters under which $10 \%, 50 \%$, and $90 \%$ of the particles are within the distribution. Each analysis was repeated ten times. The rheological behavior was determined by obtaining a flow curve from a rotary rheometer (HAKKE RheoStress 1-RS1 Thermo Electron Corporation, Karlsruhe, Germany), using a Z34 DIN coaxial cylinder sensor system and a temperature bath at $20 \pm 1{ }^{\circ} \mathrm{C}$ (HAKKE Phoenix 2 controller, Thermo Electron Corporation, Kalsruhe, Germany). The samples were subjected to three ascending and three descending sweeps with a velocity gradient from 0 to $300 \mathrm{~s}^{-1}$. Since all the samples exhibited a non-Newtonian pseudoplastic behavior, samples' flow behaviors were modeled using the Ostwald-de Waele model.

$$
\sigma=K \dot{\gamma}^{n}
$$

The parameters $\mathrm{K}$ (consistency index $\left(\mathrm{Pa} \cdot \mathrm{s}^{\mathrm{n}}\right)$ ) and $\mathrm{n}$ (flow behavior index (dimensionless)) for the model were obtained by regression using the software HAAKE RheoWin Data Manager v.3.61.0004. The results stated are the average of triplicates.

Color coordinates were obtained through a reflection spectrum between 400 and $700 \mathrm{~nm}$, using a MINOLTA brand spectrocolorimeter (Model CM-3600D, Minolta, Osaka, Japan) with D65 illuminant and a $10{ }^{\circ} \mathrm{C}$ observer as references. The resulting $\mathrm{CIE}-\mathrm{L}^{*} \mathrm{a} \mathrm{b}^{*}$ color coordinates allowed for the calculating of the psychometric coordinates: tone ( $\left.h^{*} a b\right)$ and chrome ( $\left.C^{*} a b\right)$. The color difference $(\Delta E)$ between each homogenized juice and the nonhomogenized one (reference) was calculated. All determinations were made by triplicate. 


\subsection{Antioxidant properties}

Antioxidant capacity by DPPH and ABTS methods, total phenols, flavonoids and spermidine content, and polyphenolic compounds profile of the lulo fruit and homogenized and nonhomogenized juices were determined.

For determination of total phenols and flavonoids content and antioxidant capacity by DPPH and ABTS method, antioxidants were extracted from fruit or from juice by diluting the samples in an 80:20 (v/v) methanolwater solution at a $1: 10$ ratio $(\mathrm{w} / \mathrm{v})$ and centrifuged at $10,000 \mathrm{rpm}$ and $20^{\circ} \mathrm{C}$ for 5 min (Selecta, "Medifriger BL-S"). Subsequent analyses were carried out on the supernatant (extract) by triplicate.

Total phenol content was determined following the Folin-Ciocalteu method [16,17]. For this procedure, $0.125 \mathrm{~mL}$ of extract, $0.125 \mathrm{~mL}$ of FolinCiocalteu reagent (Sig-ma-Aldrich, Saint Louis, USA), and $0.5 \mathrm{~mL}$ of doubledistilled water were mixed and allowed to react for 6 min. After that, $1.25 \mathrm{~mL}$ of $7 \%(\mathrm{w} / \mathrm{v})$ sodium carbonate solution and $1 \mathrm{~mL}$ of double distilled water were added. Absorbance was measured in a spectrophotometer (Thermo Scientific, Helios Zeta U/Vis, Loughborough, England) at $765 \mathrm{~nm}$ after $90 \mathrm{~min}$. A standard gallic acid curve ranging from 0 to $500 \mathrm{mg} / \mathrm{L}$ was obtained. Results were expressed in milligrams of gallic acid equivalent (GAE) per gram of sample.

Flavonoid content was determined following the method described by Luximon-Ramma et al. [18]. In this case, $1.5 \mathrm{~mL}$ of extract and $1.5 \mathrm{~mL}$ of a $2 \%$ $(\mathrm{w} / \mathrm{v})$ aluminum chloride solution in methanol were mixed and left in the dark for $10 \mathrm{~min}$. Absorbance was measured on a spectrophotometer (Thermo Scientific, Helios Zeta U/Vis, Loughborough, England) at $368 \mathrm{~nm}$. The resulting data were compared to a standard quercetin curve ranging from 0 to 350 $\mathrm{mg} / \mathrm{L}$. The results were expressed in milligrams of quercetin equivalent (EQ) per gram of sample.

Antioxidant capacity by DPPH (2.2-diphenyl-1-picrylhydrazyl) radical was deter-mined following the method described by Kuskoski et al. [19] and Stratil et al. [20], with some modifications. A blend made up of $0.1 \mathrm{~mL}$ of the extract, $0.9 \mathrm{~mL}$ of methanol, and $2 \mathrm{~mL}$ of a $100 \mu \mathrm{M}$ methanol-DPPH (39.4 $\mu \mathrm{g} / \mathrm{mL}$ ) solution was prepared. After 60 min of reaction time, absorbance was measured at $517 \mathrm{~nm}$ in a spectrophotometer (Thermo Scientific, Helios Zeta $\mathrm{U} / \mathrm{Vis}$, Loughborough, England). The results were expressed as milligrams of 
Trolox equivalent (TE) per gram of sample, using the Trolox calibration curve within a 0 to $500 \mathrm{mg} / \mathrm{L}$ concentration range.

Antioxidant capacity by ABTS (2.2'-azino-bis-3-ethylbenzothiazoline6-sulfonic acid) radical was evaluated following the method described by $\mathrm{Re}$ et al. [21]. A solution containing $7 \mathrm{mM}$ of ABTS radical and $2.45 \mathrm{mM}$ of potassium persulfate was prepared and left in the dark at room temperature for $16 \mathrm{~h}$. ABTS+ was mixed with phosphate buffer to reach an absorbance of $0.70 \pm 0.02$ at $734 \mathrm{~nm}$. Then, $0.1 \mathrm{~mL}$ of extract was added to $2.9 \mathrm{~mL}$ of ABTS+ solution. Absorbance was measured at $734 \mathrm{~nm}$ in a spectrophotometer (Thermo Scientific, Helios Zeta UV/Vis, Loughborough, England) after 0, 3, and $7 \mathrm{~min}$ of reaction time. The results were expressed as $\mathrm{mg}$ of Trolox equivalent (TE) per gram of sample.

Polyphenolic compounds profile and spermidine content were determined by liquid chromatography-mass spectrometry (LC-MS) analysis. First, phenolic compounds were extracted according to the procedure described by Rodrigues et al. [22] and Svobodova [23], with some modifications. In brief, $5 \mathrm{~g}$ of sample were mixed with $20 \mathrm{~mL}$ of methanol/water (80:20 v/v) solution by stirring (Ultra-Turrax, Staufen, Germany) at $150 \mathrm{rpm}$ and room temperature for $1 \mathrm{~h}$. This mix was centrifuged (Beckman Coulter AvantiTM J-25, Hamburg, Germany) at $3864 \mathrm{x}$ g and $20^{\circ} \mathrm{C}$ for $5 \mathrm{~min}$ and the supernatant taken. The extraction procedure was repeated five times. Finally, the supernatant was filtered using a Whatman No. 1 paper filter and, subsequently, a $0.45 \mu \mathrm{m}$ nylon filter and then directly injected into the HPLC equipment.

The equipment used for separation and identification of phenolic compounds was an (Agilent 1290 HPLC Technologies series infinity System LC. Santa Clara, USA) system with a MS detector and a C18 $(1.7 \mu \mathrm{m}, 2.1 \times 50 \mathrm{~mm}$, Waters) UHPLC (Ultra High-Performance Liquid Chromatography) column. A flow rate of $0.4 \mathrm{~mL} / \mathrm{min}$ and an injection volume of $5 \mu \mathrm{L}$ at $30^{\circ} \mathrm{C}$ were applied. The solvents employed were $0.1 \%$ formic acid in water $(A)$ and $0.1 \%$ formic acid in methanol (B). The applied gradient elution was $10 \% \mathrm{~B}(0 \mathrm{~min}), 10 \% \mathrm{~B}$ (5 min), 100\% B (12 min); 100\% B (18 min), 10\% B (18.5 min), 10\% B (25 min). An automated calibration was performed using an external calibrant delivery system (CDS) which infuses calibration solution prior to sample introduction. The selected system was an (AB SCIEX Triple TOF 5600 MS, Santa Clara, USA) which was used for data acquisition in both positive and negative modes over 
a mass range of $80-1000 \mathrm{~m} / \mathrm{z}$, under the following conditions: both negative and positive ion modes; ion source gas 1 (GC1): 55 psi; ion source gas 2 (GC2): 55 psi; gas curtain 1:25 psi at 400 C; negative ion spray voltage (ISVF): -4500 ; collision energy (CE): -50 ; positive ion spray voltage (ISVF): 5500; collision energy (CE): 30; accumulation time for both positive and negative modes set at $100 \mathrm{~ms}$. The MS used the IDA (Information-Dependent-Acquisition) acquisition method, the survey scan type (TOF-MS, Time of Fligh-MassSpectrometry) and the dependent scan type (product ion) with collision energy set at $50 \mathrm{~V} / 30 \mathrm{~V}$. Likewise, spermidine was quantified using the LCMS/MS (Liquid Chromatography-Mass Spectrometry) method by means of direct extrapolation on the standard curve. The results were expressed in $\mathrm{mg} / \mathrm{L}$. Determinations were done by triplicate.

\subsection{Statistical analysis}

The statistical analysis of the data was performed in a Statgraphics Centurion XVII software package, making use of simple or multifactorial analysis of variance (ANOVA) at a $95 \%$ confidence level $(p<0.05)$.

\section{Results and discussion}

\subsection{Vacuum impregnation properties of lulo fruit}

Lulo fruit impregnation parameters provide information on the volume of external liquid that can be incorporated into the fruit tissue by controlled VI. This, in turn, informs us on the viability of incorporating protectants, preservatives, physiologically active compounds, or other additives in the porous structure of the fruit, aiming at its preservation or the formulation of new functional foods [10]. According to Fito et al. [14], the physicochemical properties of the impregnation liquid (mainly viscosity) affect the impregnation parameters, but it is the structural features of the impregnated tissue that are decisive. It is necessary that the tissue have sufficiently big intercellular and hollow spaces which, upon slicing, ensure the presence of open pores and, hence, the flow of the impregnating liquid into the porous structure of the fruit.

Table 1 shows the mean and standard deviation values of the VI parameters corresponding to three different lulo batches impregnated with an isotonic sucrose aqueous solution. 
Table 1. Vacuum impregnation parameters of lulo fruit slices (mean \pm standard deviation.

\begin{tabular}{|c|c|c|c|c|c|c|c|}
\hline Batch & $a_{w}$ & ${ }^{\circ}$ Brix & $x_{1}$ & $\gamma_{1}$ & $\mathbf{x}$ & $\gamma$ & $\varepsilon_{\mathrm{e}}$ \\
\hline 1 & $0.995 \pm 0.001^{\mathrm{a}}$ & $8.73 \pm 0.06^{\mathrm{a}}$ & $5 \pm 7^{a}$ & $5 \pm 4^{a}$ & $8.8 \pm 1.6^{a}$ & $3 \pm 3^{a}$ & $6 \pm 4^{a}$ \\
\hline 2 & $0.996 \pm 0.003^{a}$ & $8.93 \pm 0.06^{a}$ & $2 \pm 4^{a}$ & $5 \pm 2^{a}$ & $11 \pm 2^{\mathrm{a}}$ & $3.7 \pm 0.9^{\mathrm{a}}$ & $8 \pm 2^{a}$ \\
\hline 3 & $0.994 \pm 0.002^{\mathrm{a}}$ & $8.70 \pm 0.17^{a}$ & $2.5 \pm 1.3^{a}$ & $7.1 \pm 1.0^{\mathrm{a}}$ & $8.6 \pm 0.9^{a}$ & $2.9 \pm 0.8^{\mathrm{a}}$ & $6.3 \pm 1.2^{\mathrm{a}}$ \\
\hline
\end{tabular}

The obtained values reveal the technical feasibility of this type of unitary operation on lulo fruit. No significant differences $(p>0.05)$ were observed in parameters $X 1, \gamma_{1}, \gamma$ and $\varepsilon_{e}$, while they were observed indeed in parameter $X$. A linear relation $(R 2=0.736)$ between Brix and $X$ can be observed, allowing one to state that the riper the fruit, the higher the impregnation of its porous matrix.

The observed differences are fundamentally due to the morphological and structural variability of the fruit, which certainly deserves attention when it comes to the $\mathrm{VI}$ process. Positive average values for parameters $\mathrm{X} 1(1-5 \%)$ and $X(8.6-16 \%)$ in all batches indicate the incorporation of the impregnation liquid into the porous structure of the fruit during the vacuum stage and total process, respectively. Likewise, the positive volume deformation records registered during the vacuum stage and total process, respectively, ex-pressed by $\gamma_{1}(3.9-7.1 \%)$ and $\gamma(2.9-6.6 \%)$, indicate a volumetric expansion of the fruit matrix, mainly affected by vacuum application [24]

The effective porosity $\left(\varepsilon_{\mathrm{e}}\right)$ provides information on the volumetric fraction of pores that are filled during the VI experiments. It shows favorable values between 6-9\%, which makes the lulo matrix appropriate for the VI process. Interesting observations result from comparing these results to the values obtained for several fruits and vegetables. The current lulo results are much lower than those reported by Betoret et al. [9] and Fito et al. [25] for Granny Smith apple ( $21 \pm 0.9$ ) and Soraya eggplant (64.1 \pm 2$)$, but higher than those of Chandler strawberry (6.4 \pm 0.3$)$, Hayward kiwi $(0.7 \pm 0.5)$, and Bulida apricot ( $2.2 \pm 0.2$ ). Regarding a likely significant batch effect (aw and Brix) on $\varepsilon_{\mathrm{e}}$, it can be observed that there are no significant differences due to the apparent homogeneity between the studied fruit samples. Differences in Brix and aw may be associated with different degree of ripeness that bring with them a different structural behavior of the samples during the impregnation 
process. In this way, selecting fruits with the same degree of ripeness would allow obtaining fruits with a very homogeneous response to the impregnation process.

\subsection{Physicochemical characterization}

Table 2 shows the water content, Brix, water activity, $\mathrm{pH}$ and density values of the studied fruit, and homogenized and nonhomogenized juice samples. The only significant differences $(p \leq 0.05)$ are observed between fruit and juice soluble solids content (Brix) and density, regardless of $\mathrm{HPH}$ treatment. This is due to the fact that some fruit soluble solids remain in the bagasse after juice preparation.

Comparing the density values of homogenized and nonhomogenized juices, a slight increase is produced by the homogenization pressure. This effect can be associated to a decrease in the particle size of the suspended solids and an increase in the stability of the cloud observed in homogenized fruit juices [26-28].

Particle size distribution of homogenized and nonhomogenized juice samples is presented in Figure 2. A monomodal distribution ranging from 1 to $1000 \mu \mathrm{m}$ can be observed in all juice samples, with a small irregular peak between 10 and $50 \mu \mathrm{m}$ in the nonhomogenized juice. Although there is a remarkable reduction in particle size as a consequence of homogenization, all curves exhibit a similar particle size distribution pattern.

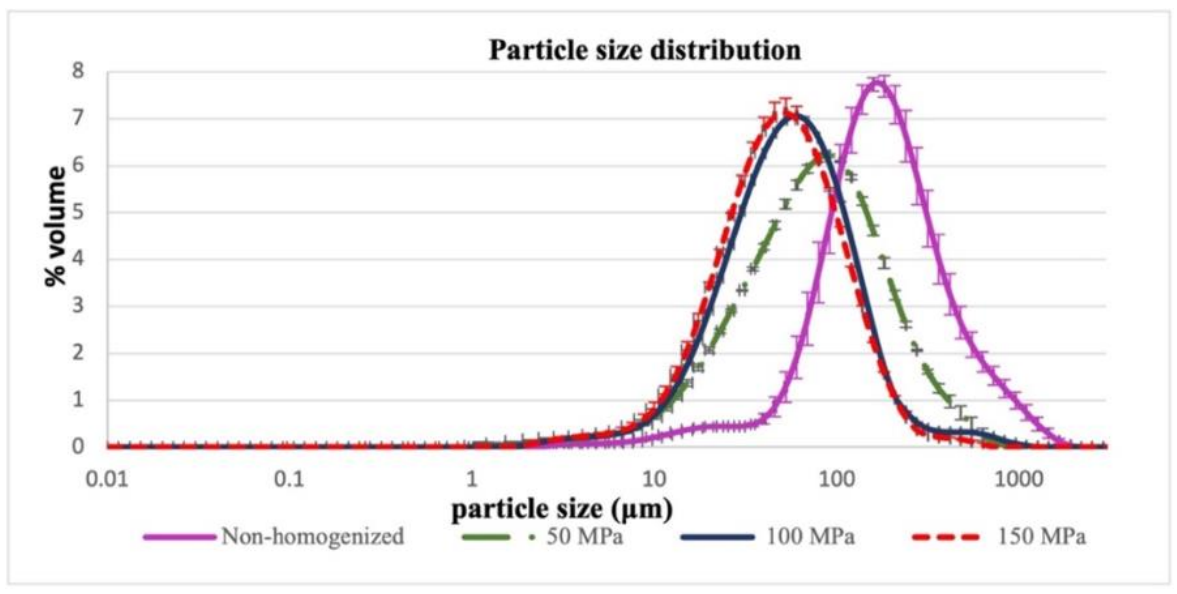

Figure 2. Effect of homogenization pressure on the particle size distribution of homogenized and nonhomogenized juice. 
The above is corroborated by statistical analysis of the volume ( $D[4,3])$ and area $(D[3,2])$ based diameters, which reveals a significantly negative correlation between homogenization pressure and particle size. The maximum and minimum diameters were, respectively, observed in the nonhomogenized juice $(251 \pm 5 \mu \mathrm{m})$ and the one homogenized at $150 \mathrm{MPa}$ $(57.94 \pm 0.14 \mu \mathrm{m})$. 
Table 2. Physicochemical characterization, water activity $\left(a_{w}\right)$, moisture content $\left(x_{w}\right)$, (g water/100 g), soluble solids, particle size, rheological properties, and CIE L*a*b* coordinates of the lulo fruit and homogenized and nonhomogenized juice. Mean \pm standard deviation of three repetitions. (Different letters in superscripts mean significant differences $(p<0.05))$.

\begin{tabular}{|c|c|c|c|c|c|}
\hline & Fruit & Nonhomogenized & $50 \mathrm{MPa}$ & $100 \mathrm{MPa}$ & $150 \mathrm{MPa}$ \\
\hline $\mathrm{X}_{\mathrm{w}}(\%)$ & $91.2 \pm 0.4$ & - & - & - & - \\
\hline$a_{w}$ & $0.994 \pm 0.003^{a}$ & $0.994 \pm 0.003^{a}$ & $0.997 \pm 0.003^{a}$ & $0.995 \pm 0.001^{a}$ & $0.996 \pm 0.000^{a}$ \\
\hline Brix & $8.88 \pm 0.17^{b}$ & $6.57 \pm 0.12^{a}$ & $6.4 \pm 0.4^{\mathrm{a}}$ & $6.33 \pm 0.15^{a}$ & $6.4 \pm 0.4^{\text {a }}$ \\
\hline $\mathrm{pH}$ & $3.13 \pm 0.16^{a}$ & $3.31 \pm 0.01^{a}$ & $3.12 \pm 0.02^{a}$ & $3.18 \pm 0.03^{a}$ & $3.18 \pm 0.03^{a}$ \\
\hline$\rho\left(\mathrm{g} / \mathrm{cm}^{3}\right)$ & $1.16 \pm 0.07^{b}$ & $1.036 \pm 0.018^{a}$ & $1.06 \pm 0.04^{a, b}$ & $1.07 \pm 0.02^{a, b}$ & $1.090 \pm 0.013^{a, b}$ \\
\hline \multicolumn{6}{|c|}{ Particle size } \\
\hline $\mathrm{D}[4,3]$ & - & $251 \pm 5^{d}$ & $124 \pm 3^{c}$ & $75.5 \pm 1.2^{b}$ & $57.94 \pm 0.14^{a}$ \\
\hline$D[3,2]$ & - & $102.3 \pm 0.5^{d}$ & $49.9 \pm 1.5^{c}$ & $35.28 \pm 0.07^{b}$ & $26.83 \pm 0.19^{a}$ \\
\hline $\mathrm{d}_{10}(\mu \mathrm{m})$ & - & $75.8 \pm 0.3^{d}$ & $25.7 \pm 1.1^{c}$ & $18.94 \pm 0.11^{b}$ & $15.63 \pm 0.03^{a}$ \\
\hline $\mathrm{d}_{50}(\mu \mathrm{m})$ & - & $184.2 \pm 1.6^{d}$ & $99.82 \pm 0.09^{c}$ & $60.01 \pm 0.11^{b}$ & $45.02 \pm 0.19^{a}$ \\
\hline $\mathrm{d}_{90}(\mu \mathrm{m})$ & - & $524 \pm 17^{d}$ & $247 \pm 3^{c}$ & $153.7 \pm 2.0^{b}$ & $114.2 \pm 0.5^{a}$ \\
\hline \multicolumn{6}{|c|}{ Rheological properties } \\
\hline$K\left(\mathrm{~Pa} . \mathrm{s}^{\mathrm{n}}\right)$ & - & $0.39 \pm 0.12^{a}$ & $0.9 \pm 0.4^{b}$ & $0.79 \pm 0.02^{a, b}$ & $1.3 \pm 0.5^{b}$ \\
\hline$n$ & - & $0.44 \pm 0.06^{b}$ & $0.37 \pm 0.04^{a}$ & $0.37 \pm 0.00^{a}$ & $0.34 \pm 0.04^{a}$ \\
\hline $\mathrm{R}^{2}$ & & 0.99 & 0.98 & 0.96 & 0.98 \\
\hline \multicolumn{6}{|c|}{ Color } \\
\hline $\mathrm{L}^{*}$ & - & $40.4 \pm 0.4^{b}$ & $40.16 \pm 0.11^{a, b}$ & $39.409 \pm 0.012^{a}$ & $39.44 \pm 0.08^{a}$ \\
\hline$a^{*}$ & - & $9.5 \pm 0.2^{b}$ & $9.08 \pm 0.07^{a}$ & $9.15 \pm 0.01^{a, b}$ & $8.829 \pm 0.011^{a}$ \\
\hline$b^{*}$ & - & $34.9 \pm 1.4^{a}$ & $35.4 \pm 0.5^{a}$ & $34.54 \pm 0.01^{a}$ & $33.8 \pm 0.2^{a}$ \\
\hline Cab* & - & $36.2 \pm 1.3^{a}$ & $36.5 \pm 0.5^{a}$ & $35.73 \pm 0.01^{a}$ & $34.9 \pm 0.2^{a}$ \\
\hline hab* & - & $74.7 \pm 0.2^{a}$ & $75.61 \pm 0.09^{b}$ & $75.16 \pm 0.01^{a, b}$ & $75.37 \pm 0.13^{a, b}$ \\
\hline$\Delta \mathrm{E}$ & - & - & $0.8 \pm 0.2^{a}$ & $1.250 \pm 0.014^{\mathrm{a}, \mathrm{b}}$ & $1.74 \pm 0.13^{b}$ \\
\hline
\end{tabular}

Values with different superscript letters in a column are significantly different $(\mathrm{p} \leq 0.05)$.

Comparing these results with those reported by Salustiana orange juice $(150.1 \pm 4.8,107.7 \pm 4.1 \mu \mathrm{m})$ and Ortanique mandarin $(372.1 \pm 1.9,122.9$ $\pm 2.2 \mu \mathrm{m}$ ) exhibits slightly similar values to those obtained for diameter 
$(D[4,3])$ in the present study. However, the $(D[4,3])$ and $(D[3,2])$ diameter values found by Castagnini et al. [29] in cranberry juice are much lower. Both authors claim particle size reduction in juices treated with homogenization pressure.

Particle size values below $10 \%, 50 \%$, and $90 \%$ of the particles present in the lulo juices studied in the present work are much higher than those reported by Castagnini et al. [29] for homogenized cranberry juice.

Values of rheological properties show a pseudoplastic behavior in homogenized and nonhomogenized lulo juices (Table 2). Non-Newtonian behavior of fruit juices results from complex interactions between soluble sugars, colloidal pectic substances, and suspended solids. Pseudoplastic behavior reflects a structural reorganization of fluid particles as the velocity gradient increases, not reaching an asymptotic viscosity value. In general, in fruit juices, the higher the soluble solids content, the higher the consistency index. Nonhomogenized lulo juice have a low consistency index (K) and a lower than 1 value of the flow behavior index $(n)$, reflecting the deviation from Newtonian behavior $(n=1)$ and a good capacity to be pumped and circulated in industrial plants. A significant influence of homogenization pressure on the rheology of the lulo juice as compared to the nonhomogenized one is observed. Yet, no significant differences can be observed across the homogenized samples (50 and $150 \mathrm{MPa}$ ). It can also be noted that there is no clear in-creasing or decreasing trend in the consistency index $(\mathrm{K})$ after increasing the homogenization pressure.

Although sifting the juice drags a considerable amount of soluble solids, when the juice is subjected to HPH, particle size is reduced, the stability of suspended solids in-creased, and the juice behavior modified as if it increased in soluble solids content (higher $\mathrm{K}$ value). While some authors have reported similar results in terms of particle size re-duction due to homogenization, others have found contrasting results for factor K. In studying the effect of homogenization on the properties of mixed peach-and-carrot juice, the authors of [26] observed a drop in the consistency index $(\mathrm{K})$ and the flow behavior index. Similar trends were observed by Leite et al. [30] in orange juice and by Silva et al. [31], who studied the effect of homogenization on pineapple pulp, finding that it reduced pseudoplastic behavior (i.e., it increased the flow behavior index $\mathrm{n}$ and reduced the index of consistency $\mathrm{K}$ ). Probably accounting for these contrasts, the authors of [32] have shown that 
the cell walls of each plant behave differently when subjected to $\mathrm{HPH}$. That is to say, each fruit juice requires a different shear effort, suggesting that HPH may produce contrasting effects on different products, being mainly conditioned by the chemical nature of the components that are suspended in the juice. In studying blueberry juice, Castagnini et al. [29] obtained a consistency index of $0.57 \pm 0.03 \mathrm{~Pa}$.sn and a flow behavior index of $0.33 \pm 0.02$. Chiralt et al. [33] reported a $K$ value of 2 Pa.sn and an $n$ value of 0.43 for tomato juice with $12.8 \%$ solids and a $K$ value of $6.48 \mathrm{~Pa}$.sn and an $n$ value of 0.74 for concentrated orange juice homogenized at high pressures. According to these reported data, the consistency of homogenized and nonhomogenized lulo juice is similar to that of blueberry juice, which is of commercial use.

Table 2 shows the parameters $L^{*}, a^{*}, b^{*}: L^{*}$ for perceptual lightness, and $a^{*}$ and $b^{*}$ for the four unique colors of human vision. Coordinate $a^{*}$ is relative to the green-red op-ponent colors, with negative values toward green and positive values toward red. The $b^{*}$ coordinate represents the blue-yellow opponents, with negative numbers toward blue and positive toward yellow. In addition, the psychrometric coordinates chrome (Cab*), hue (hab*) and $\Delta E$ (total color change), as functions of homogenization pressure ranging from homogenized to nonhomogenized lulo juice have been included. A slight reduction can be observed in all parameters under increased homogenization pressure.

The analysis of variance revealed a significant effect of homogenization pressure on all variables except for $b^{*}$ and $C a b^{*}$, and $L^{*}$ values show significant differences between the nonhomogenized juice and the homogenized ones, the former being slightly brighter than the latter. As for parameter $a^{*}$, the nonhomogenized juice exhibits the highest value. On the other hand, hue (hab*) exhibits differences between the nonhomogenized juice and the one homogenized at $50 \mathrm{MPa}$, the former one showing a less orange coloration. No significant differences were observed between the values of the studied color parameters among the homogenized juices. Thus, it can be said that juice color was not affected by pressure intensity.

Global color differences were found between the juice homogenized at $150 \mathrm{MPa}$ and the nonhomogenized one used as reference. However, the visual perception of the color changes in the analyzed juices, described by the $\Delta \mathrm{E}$ value, was not appreciated. 


\subsection{Antioxidant properties}

Figure 3 show the effect of the homogenization pressure on total phenol content, flavonoid content, and antioxidant capacity by DPPH• and ABTS radical methods.

The DPPH• method is more sensitive to hydrophobic flavanones, while the ABTS+ method is more sensitive to hydrophilic antiradicals [34]. The ABTS ${ }^{+}$ free radical decol-oration and the $\mathrm{DPPH}^{\bullet}$ free radical-scavenging assays have been reported as useful tools to evaluate antiradical activities of different fruits [9].

In comparing obtained values through statistical analysis, significant total phenol differences can be observed between the nonhomogenized juice and that homogenized at $150 \mathrm{MPa}$. Juices homogenized at $50 \mathrm{MPa}$ and 100 $\mathrm{MPa}$ show intermediate values approaching the value of the fruit with increasing the pressure. Total flavonoids content present significant differences between fruit and juices, but this difference is more pronounced when applying the homogenization treatment.

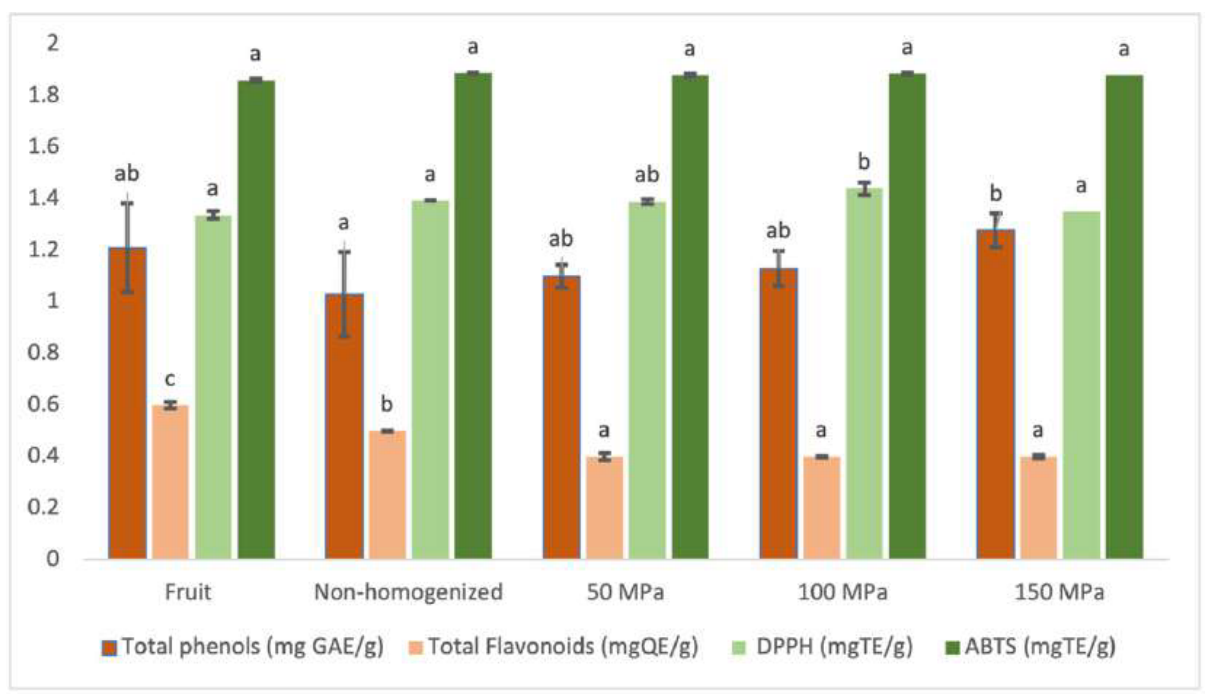

Figure 3. Total phenolic content, total flavonoids content, and antioxidant capacity of lulo fruit and nonhomogenized and homogenized lulo juices by the DPPH (2.2-diphenyl-1-picrylhydrazyl) and ABTS+ (2.2'-azino-bis-3-ethylbenzothiazoline-6-sulfonic acid) methods. Different letters for the same determination indicate significant differences $(p \leq 0.05)$. 
In both cases, obtaining juice decreases the content of total phenols and flavonoids from fruit. It would be associated with the removal of the solid fraction, especially from the skin which is very rich in these compounds [35]. However, the application of an HPH produces a phenol recovery, as the pressure value applied increases while the same treatment reduces flavonoids content. As it has been explained by other authors [36], food matrix properties and processing can promote a different effect on bioactive compounds. The forces and temperature stresses created in the homogenization valve in $\mathrm{HPH}$ treatment could lead to a degradation of flavonoid during homogenization in this case. However, in those cases in which degradation of bioactive compounds has not been occurred yet, particle size decrease can facilitate the extraction, as it is observed in the case of phenolic compounds.

The values found in the current fruit samples do not differ much from those obtained by Contreras-Calderón et al. [1] (0.583 $\pm 0.024 \mathrm{mg} \mathrm{GAE} / \mathrm{g}$, fresh sample); by Igual et al. [37] ( $0.811 \pm 0.016 \mathrm{mg} \mathrm{GAE} / \mathrm{g}$, fresh sample); and by Vasco et al. [38] (0.91 $\pm 0.17 \mathrm{mg} \mathrm{GAE} / \mathrm{g}$, fresh sample), also in lulo. On the other hand, the flavonoid content values re-ported by Igual et al. [37] were $0.16 \pm 0.02 \mathrm{mg} R E$ equivalents/g, which is a lower value than those obtained in this study ( $\mathrm{mg}$ of quercetin equivalent).

The results of antioxidant capacity vary from $1.44 \pm 0.02 \mathrm{mg} \mathrm{TE} / \mathrm{g}$ (82.40 $\pm 1.41 \%$ inhibition) to $1.35 \pm 0.06 \mathrm{mg} \mathrm{TE} / \mathrm{g}$ (76.8 $\pm 0.8 \%$ inhibition) for the assays by DPPH $\bullet$; and from $1.88 \pm 0.03 \mathrm{mg} \mathrm{TE} / \mathrm{g}(89.0 \pm 1.5 \%$ inhibition) to $1.86 \pm 0.01 \mathrm{mg} \mathrm{TE} / \mathrm{g}(87.9 \pm 0.3 \%$ inhibition $)$ for the ABTS+ assays.

The values obtained by the $\mathrm{ABTS}^{+}$method in both fruit and juice samples do not show significant differences. However, by the DPPH method, the juice homogenized at $100 \mathrm{MPa}$ shows the highest value being significantly different from all other samples. The decrease observed in the content of total phenol and flavonoid contents in the juice compared with the fruit is not reflected when analyzing the antiradical activity. This could be explained by the fact that the liquefaction and $\mathrm{HPH}$ treatment may cause unbounding or chemical changes in some phenolic compounds of the fruit, giving rise to other compounds with antiradical capacity that compensate for the loss associated with sieving [39].

Authors like Forero et al. [5] and Contreras-Calderón et al. [1] in analyzing the same fruit have reported values of $71.0 \pm 2.3 \mathrm{mg} \mathrm{TE} / \mathrm{g}$ solid and 
$3.05 \pm 0.21 \mathrm{mg} \mathrm{TE} / \mathrm{g}$ fresh weight, respectively. The former authors obtained a fairly high value, while the latter reported a value even higher value than the one found in this study for the fruit and homogenized and nonhomogenized juices. Contrastingly, in applying the DPPH • method, Vasco et al. [38] found records of $0.80 \pm 0.22 \mathrm{mg} \mathrm{TE} / \mathrm{g}$ of fresh sample, with this value being lower than those reported in this study, which vary from 1.34 to $1.44 \mathrm{mg} T E / g$ of sample.

\subsection{Profile of phenolic compounds by high-performance liquid chromatography coupled to mass spectrometry (LC-MS/MS)}

Figure 4 shows the percentage distribution class of polyphenolic compounds in the lulo fruit and its homogenized and nonhomogenized juices.

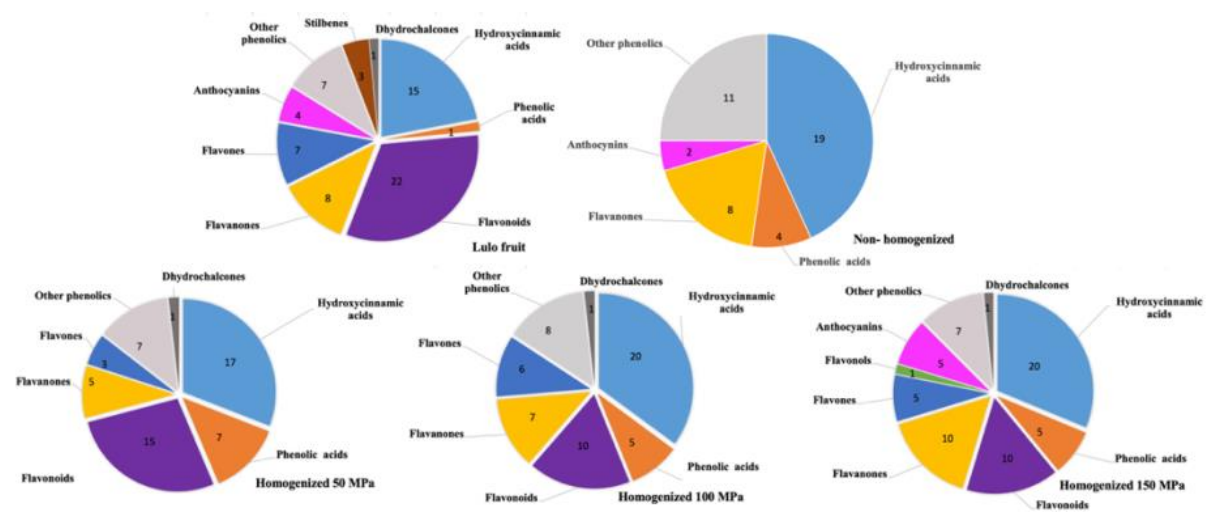

Figure 4. Percentage distribution of phenolic compounds identified in lulo fruit, nonhomogenized, and homogenized lulo juice.

A greater variety of phenolic components has been identified in homogenized juices than in nonhomogenized ones, and this variety increases with increasing homogenization pressure. Results are consistent with the results on the total phenol content previously shown in Figure 3.

In general, hydroxycinnamic acids and flavonoids were the main phenolic subclass found. It is coherent with a previous study reported by Gancel et al. [6] showing that hydroxycinnamic acids and flavonoids (i.e., quercetin glycosides, kaempferol derivatives, and 5-O-caffeoylquinic acid) are the dominant phenolic compounds in all parts of the lulo fruit [6].

Suárez-Jacobo et al. [40] also detected an increase in hydroxycinnamic acids in clarified apple juice when pressures of 100, 200, and $300 \mathrm{MPa}$ were 
applied, although the general differences between the studied antioxidant activity assessment methods were not significant. Velázquez-Estrada et al. [41] have shown that orange juice homogenized at 200 and $300 \mathrm{MPa}$ increased the content of flavonoids which, in this beverage with high hesperidine content, precipitate forming crystals that intertwine with proteins and other compounds.

On the other hand, it is important to mention the absence of flavonoids in the nonhomogenized lulo juice. Nevertheless, flavanones have been identified. It can be attributed to the fact that, during its elaboration, some phenolic groups (flavonoids) are bound to sugars or other molecules, thus remaining integrated in the cloud fraction and making them less accessible. Therefore, their release requires physical phenomena related to, in this case, the HPH treatment [8,42-44].

Some studies have shown that the Solanaceae family, especially the genus Solanum, are rich sources of antioxidants, such as phenolic compounds and flavonoids, and alkalis. The presence of these compounds in food has a positive impact, mainly as free radical scavengers. In addition to their nutritional benefits, they have also been associated with various biological activities such as anti-inflammatory, antitumor, and benefits related to cardiovascular diseases that include hypertension [45-48].

Tables S1-S7 included as complementary files present the identified compounds by LC-MS/MS in the fresh fruit extracts and their nonhomogenized and homogenized juices at different pressures and their retention time, experimental $\mathrm{m} / \mathrm{z}$, theoretical mass, molecular formula, and MS/MS fragment data. A SCIEX OS software was used for the neutral molecule and error (ppm) data, which were compared to the literature. Regarding LCMS/MS, a total of 288 compounds were identified, including 91 hydroxycinnamic acids, 22 phenolic acids, 57 flavonoids, 38 flavanones, 21 flavones, 1 flavanol, 40 anthocyanins, 7 other phenolics, 3 stilbenes, and 4 dihydrochalcones. Qualitatively speaking, flavonoids (flavanones, flavons, and flavonols) represent the main phenolic class in this analysis, wherein 116 compounds were found in the fresh fruit and its juices homogenized at different pressures $(50,100$, and $150 \mathrm{MPa})$. For their part, hydroxycinnamic acids were the second class, followed by other phenolics and phenolic acids. Hence, it can be said that fresh lulo fruit contains phenolic compounds of interest. 
Table S7 shows $[\mathrm{M}-\mathrm{H}]$-derived ions, MS2 fragments, and molecular formula for identified compounds. Compound 1 was identified as caffeic acid with [M-H]- 179 and MS2 fragment $\mathrm{m} / \mathrm{z}$ 135, 134, 89, reported by other authors [49-51]. Compounds 2, 3, and 4 presented the same molecular ion [M-H]- 353 with a MS2 fragment $\mathrm{m} / \mathrm{z}$ 191/179. These were described by $[6,23,52-56]$

Previous studies Park [57] showed that the presence of 5caffeoylquinic acid and caffeic acid in fruits reduces the risk of suffering cardiovascular diseases through the suppression of $p$-selectin.

Compounds 5, 6, and 7 were assigned as p-coumaroylquinic acid, 4-pcoumaroylquinic acid, and 5-p-coumaroylquinic acid, respectively, with molecular mass $[\mathrm{M}-\mathrm{H}]-=337$ and with a MS2 fragment at $\mathrm{m} / \mathrm{z} 191,163$ as reported by Pereira et al. [58], Gutiérrez Ortiz et al. [59], Brahem et al. [52], Mikulic-Petkovsek et al. [60], Gómez-Romero et al. [55], and RodríguezMedina et al. [61]. Compounds 8 and 9 were, respectively, identified as quercetin-3-O-rhamnoside ( $[\mathrm{M}-\mathrm{H}]-=447 \mathrm{MS} 2$ fragment at $\mathrm{m} / \mathrm{z} 301)$ and quercetin-3-O-rutinoside ([M-H]- $=606 \mathrm{MS} 2$ fragment at $\mathrm{m} / \mathrm{z} 300)$. These compounds have also been reported by Liu et al. [62], Kolnaik-Ostek et al. [53], Dorta et al. [63], and Fu et al. [64]. Compounds 10 and 11 correspond to isorhamnetin-3-O-rutinoside; isorhamnetin-3-0-rutinoside, respectively. Likewise, compounds 12 and 13 corresponding to kaempferol 3-O- rutinoside and kaempferol 3-0-glucoside; compounds 14,15 , and 16 were identified as narirutin, phloridzin, and p-coumaroyl glucose, in that order. Similarly, the compounds coumarin, sesamol, naringenin, malvidin 3-0-(6-acetyl-glucoside) were also identified and reported by Brahem et al. [52], Diaz-García et al. [51], Kolniak-Ostek et al. [53], and Phenol-Explorer Database [65]. Baret et al. [66] reported that polyphenols and flavonoids, such as resveratrol, quercetin, epigallocathechin-3-gallate, and curcumin, help reduce fat storage, blood pressure, blood glucose, and hemoglobin-A1c, as well as reducing insulin resistance. They showed that some compounds such as caffeic acid, gallic acid, myricetin, and catechin protect oxidative stress and help prevent cardiovascular diseases. Furthermore, Asgary et al. [67] reported that consuming pomegranate juice, which has a very similar compound to the lulo fruit juice samples studied, for 2 weeks exerts a positive effect on hypertensive individuals, and these same authors found that pomegranate juice can be 
considered as an effective complement to antihypertensive medications and as a component of the daily regimen for patients at high risk of hypertension.

Table S7, also included as a complementary file, show the polyamines identified in fruit and juice samples. The same compounds were identified by Svobodova et al. [23] in peaeggplant, Wu et al. [68] in eggplant, and Rodrigues et al. [22] in mana-cubiu.

Forero et al. [7] demonstrated the potential of the lulo as an antihypertensive due to its free bioactive amines: $\mathrm{N}^{1}, \mathrm{~N}^{4}, \mathrm{~N}^{8}$ tris(dihydrocaffeoyl) spermidine and $\mathrm{N}^{1}, \mathrm{~N}^{8}$-bis(dihydrocaffeoyl) spermidine. The inhibitory activity of the fresh and dried fruit with angiotensin I-converting enzyme confirmed beneficial effect on hypertension. In another study, Gancel et al. [6] identified the same bioactive compounds in the lulo.

Polyamines are present in food, such as milk and some plants, taking part in a wide range of biologically process, such as, cellular proliferation, free radicals scavenging, the differentiation of immune cells, and neurotransmission [69].

Bomtempo et al. [70] evaluated the presence of polyamines and other bioactive amines in four varieties of the passion fruit species, reporting high spermidine concen-trations and emphasizing the potential of the passifloras with functional properties relevant for the plant and human health.

However, the analytical determination of bioactive compounds in any food is re-quired but not sufficient. Nutritional and healthy effect of food is determined by its content in macro- and micro-nutrients, their release at the target site in the adequate form, and its suitable assimilation. These three aspects considered together define the functionality of a food and are reflected separately in digestibility, bioaccessibility, and bioavailability properties. It would be necessary to carry out in vitro digestion studies or in vivo studies to quantify these properties which may be affected both by the food matrix and by the treatments applied.

\section{Conclusions}

The results obtained have shown lulo as a fruit with advantageous physicochemical and functional properties for the development of healthy 
food products from fresh native crops of the Colombian Pacific region. Lulo fruit can provide the bases of a new fruit juice flavor as well as other products derived from its richness in polyphenols, polyamines, and other antioxidant components.

Its structural characteristics determined indirectly from the impregnation parameters would allow the incorporation of protectants, preservatives, physiologically active compounds, or other additives. This incorporation would be slightly influenced by the maturity index but not by the variability among fruits.

From the phytochemical profile as obtained by LC-MS, 288 compounds belonging to different phenolic classes were found in the fruit and its homogenized and nonhomogenized juices (mainly flavonoids and hydroxycinnamic acids). Increasing pressure of HPH treatment increase the diversity in polyphenols from juice. Additionally, bioactive amines such as N1, N4, N8-tris(dihydrocaffeoyl) spermidine and N1, N8-bis(dihydrocaffeoyl) spermidine, whose effect against hypertension has been shown in previous studies, have been identified in fruit and juice samples.

In relation to the antiradical capacity provided by antioxidant compounds, it de-creases in fresh juice compared to fruit, due to the retention of part of the solids in the filtering operation. However, it is worthwhile mentioning that the $\mathrm{HPH}$ at $100-150 \mathrm{MPa}$ is adequate for preserving the antiradical capacity of the fruit increasing the antioxidant value of fresh juice.

However, the potential beneficial effect of the lulo fruit or of any of the analyzed juices should be assessed through in vitro studies that provide information on the bioavailability and bioavailability of the analyzed components.

Supplementary Materials: The following are available online at www.mdpi.com/xxx/s1; Supplementary data included in Tables S1-S7 are available online at www.mdpi.com/xxx/s1.

Author Contributions: Conceptualization, N.B.; methodology, L.I.H.-C and N.B.; writing - original draft preparation, L.I.H.-C.; writing-review and editing, L.I.H.-C, N.B., C.B., and L.S.; funding acquisition, L.I.H.-C and N.B. All authors have read and agreed to the published version of the manuscript. 
Funding: Authors thank the grant provided to Leidy I. Hinestroza by Technological University of Chocó-Colombia [Fortalecimiento de los Encadenamientos Productivos de las Subregiones del Chocó. BPIN 2013000100284].

\section{References}

1. Contreras-Calderón, J.; Calderón-Jaimes, L.; Guerra-Hernández, E.; García-Villanova, B. Antioxidant capacity, phenolic content and vitamin $C$ in pulp, peel and seed from 24 exotic fruits from Colombia. Food Res. Int. 2011, 44, 2047-2053.

2. Ministerio de Salud y Protección Social Análisis de Situación de Salud. Colombia. Available online: https://www.minsalud.gov.co/salud/publica/epidemiologia/Paginas/analisis-desituacion-de-salud-.aspx (accessed on 25 August 2019).

3. WHO Health Topics: Hypertension. Available online: https://www.who.int/newsroom/fact-sheets/detail/hypertension (accessed on 2 January 2020).

4. Ramírez, F.; Kallarackal, J.; Davenport, T.L. Lulo (Solanum quitoense Lam.) reproductive physiology: A review. Sci. Hortic. (Amsterdam) 2018, 238, 163-176.

5. Forero, D.P.; Orrego, C.E.; Peterson, D.G.; Osorio, C. Chemical and sensory comparison of fresh and dried lulo (Solanum quitoense Lam.) fruit aroma. Food Chem. 2015, 169, 85-91.

6. Gancel, A.L.; Alter, P.; Dhuique-Mayer, C.; Ruales, J.; Vaillant, F. Identifying carotenoids and phenolic compounds in naranjilla (Solanum quitoense Lam. var. Puyo hybrid), an Andean fruit. J. Agric. Food Chem. 2008, 56, 11890-11899.

7. Forero, D.P.; Masatani, C.; Fujimoto, Y.; Coy-Barrera, E.; Peterson, D.G.; Osorio, C. Spermidine derivatives in lulo (Solanum quitoense Lam.) fruit: Sensory (taste) versus biofunctional (ACE-inhibition) properties. J. Agric. Food Chem. 2016, 64, 5375-5383.

8. Mesa, J.; Hinestroza-Córdoba, L.I.; Barrera, C.; Seguí, L.; Betoret, E.; Betoret, N. High homogenization pressures to improve food quality, functionality and sustainability. Molecules 2020, 25, 3305.

9. Betoret, E.; Sentandreu, E.; Betoret, N.; Fito, P. Homogenization pressures applied to citrus juice manufacturing. Functional properties and application. J. Food Eng. 2012, 111, 28-33.

10. Betoret, E., Betoret, N., Vidal, D., Fito, P. Functional foods development: Trends and technologies. Trends in Food Science and Technology 2011, 22 (9), pp. 498-508.

11. Betoret, E.; Betoret, N.; Rocculi, P.; Dalla Rosa, M. Strategies to improve food functionality: Structure-property relationships on high pressures homogenization, vacuum impregnation and drying technologies. Trends Food Sci. Technol. 2015, 46, 1-12.

12. Betoret, E.; Sentandreu, E.; Betoret, N.; Codoñer-Franch, P.; Valls-Bellés, V.; Fito, P. Technological development and functional properties of an apple snack rich in flavonoid from mandarin juice. Innov. Food Sci. Emerg. Technol. 2012, 16, 298-304.

13. Fito, P.; Chiralt, A.; Barat, J.; Martinez-Monzo, J. Vacuum Impregnation in Fruit Processing. In Food Preservation Technology; Lozano, J., Añon, C., Parada.Aries, E., Barbosa-Cánovas, P., Eds.; Gustavo Trends in Food Engineering, Technomic Publishing Company: Lancaster, PA, USA, 2000; pp. 149-164, ISBN 1-56676-991-4.

14. Fito, P.; Andrés, A.; Chiralt, A.; Pardo, P. Coupling of Hydrodynamic Mechanism and Deformation-Relaxation Phenomena during Vacuum Treatments in Solid Porous FoodLiquid Systems. J. Food Eng. 1996, 27, 229-240. 
15. AOAC. Official Method 973.18 Official Methods of Analysis of the Association of Official Analytical Chemists, 18th ed.; Association of Official Analytical Chemist: Arlington, VA, USA, 2000.

16. Singleton, V.L.; Orthofer, R.; Lamuela-Raventós, R.M. Analysis of total phenols and other oxidation substrates and antioxidants by means of folin-ciocalteu reagent. Methods Enzymol. 1999, 299, 152-178.

17. Wolfe, K.L.; Liu, R.H. Apple peels as a value-added food ingredient. J. Agric. Food Chem. 2003, 51, 1676-1683.

18. Luximon-Ramma, A.; Bahorun, T.; Soobrattee, M.A.; Aruoma, O.I. Antioxidant activities of phenolic, proanthocyanidin, and flavonoid components in extracts of Cassia fistula. J. Agric. Food Chem. 2002, 50, 5042-5047.

19. Kuskoski, E.M.; Asuero, A.G.; Troncoso, A.M.; Mancini-Filho, J.; Fett, R. Aplicación de diversos métodos químicos para determinar actividad antioxidante en pulpa de frutos. Ciência e Tecnol. Aliment. 2005, 25, 726-732.

20. Stratil, P.; Klejdus, B.; Kubáň, V. Determination of total content of phenolic compounds and their antioxidant activity in vegetables-Evaluation of spectrophotometric methods. J. Agric. Food Chem. 2006, 54, 607-616.

21. Re, R.; Pellegrini, N.; Proteggente, A.; Pannala, A.; Yang, M.; Rice-Evans, C. Antioxidant activity applying an improved ABTS radical cation decolorization assay. Free Radic. Biol. Med. 1999, 26, 1231-1237.

22. Rodrigues, E.; Mariutti, L.R.B.; Mercadante, A.Z. Carotenoids and phenolic compounds from Solanum sessiliflorum, an unexploited amazonian fruit, and their scavenging capacities against reactive oxygen and nitrogen species. J. Agric. Food Chem. 2013, 61, 3022-3029.

23. Svobodova, B.; Barros, L.; Sopik, T.; Calhelha, R.C.; Heleno, S.; Alves, M.J.; Walcott, S.; Kuban, V.; Ferreira, I.C.F.R. Non-edible parts of Solanum stramoniifolium Jacq.-a new potent source of bioactive extracts rich in phenolic compounds for functional foods. Food Funct. 2017, 8, 2013-2021.

24. Cortéz Rodriguez, M.; Herrera Herrera, E.A.; Gil González, J.H. Impregnación de Uchua (Physalis peruviana L.) de forma Semiesférica con una Emunsión Fortificante. Biotecnol. en el Sect. Agropecu. y Agroind. 2016, 14, 27.

25. Fito, P.; Chiralt, A.; Barat, J.M.; Andrés, A.; Martínez-Monzó, J.; Martínez-Navarrete, N. Vacuum impregnation for development of new dehydrated products. J. Food Eng. 2001, 49, 297-302.

26. Wellala, C.K.D.; Bi, J.; Liu, X.; Liu, J.; Lyu, J.; Zhou, M.; Marszałek, K.; Trych, U. Effect of high pressure homogenization combined with juice ratio on water-soluble pectin characteristics, functional properties and bioactive compounds in mixed juices. Innov. Food Sci. Emerg. Technol. 2020, 60, 102279.

27. Cerdán-Calero, M.; Izquierdo, L.; Sentandreu, E. Valencia Late orange juice preserved by pulp reduction and high pressure homogenization: Sensory quality and gas chromatography-mass spectrometry analysis of volatiles. LWT-Food Sci. Technol. 2013, 51, 476-483.

28. Betoret, E.; Betoret, N.; Carbonell, J.V.; Fito, P. Effects of pressure homogenization on particle size and the functional properties of citrus juices. J. Food Eng. 2009, 92, 18-23. 
29. Castagnini, J.M. Estudio del Proceso de Obtención de Zumo de Arándanos y su Utilización Como Ingrediente Para laObtención de un Alimento Funcional por Impregnación a Vacío. Ph.D. Thesis, Universitat Politécnica de Valéncia: Valencia, Spain, 2014.

30. Leite, T.S.; Augusto, P.E.D.; Cristianini, M. The use of high pressure homogenization (HPH) to reduce consistency of concentrated orange juice (COJ). Innov. Food Sci. Emerg. Technol. 2014, 26, 124-133.

31. Silva, V.M.; Sato, A.C.K.; Barbosa, G.; Dacanal, G.; Ciro-Velásquez, H.J.; Cunha, R.L. The effect of homogenisation on the stability of pineapple pulp. Int. J. Food Sci. Technol. 2010, 45, 2127-2133.

32. Lopez-Sanchez, P.; Svelander, C.; Bialek, L.; Schumm, S.; Langton, M. Rheology and Microstructure of Carrot and Tomato Emulsions as a Result of High-Pressure Homogenization Conditions. J. Food Sci. 2011, 76.

33. Chiralt, A.; Martinez-Navarrete, N.; González, C.; Talens, P.; Moraga, G. Propiedades Reológicas de Alimentos. Reología de Alimentos Fluidos. En: Propiedades Físicas de los Alimentos, 1st ed.; Universitat Politécnica de Valéncia-España: Valencia, Spain,2012; Chaper 4.

34. Del Caro, A.; Piga, A.; Vacca, V.; Agabbio, M. Changes of flavonoids, vitamin C and antioxidant capacity in minimally processed citrus segments and juices during storage. Food Chem. 2004, 84, 99-105.

35. Hinestroza-Córdoba, L.I.; Serna, S.D.; Seguí, L.; Barrera, C.; Betoret, N. Characterization of powdered lulo (Solanum quitoense) bagasse as a functional food ingredient. Foods 2020, 9, 723.

36. Betoret, E.; Calabuig-Jiménez, L.; Patrignani, F.; Lanciotti, R.; Dalla Rosa, M. Effect of high pressure processing and trehalose addition on functional properties of mandarin juice enriched with probiotic microorganisms. LWT-Food Sci. Technol. 2017, 85, 418-422.

37. Igual, M.; Ramires, S.; Mosquera, L.H.; Martínez-Navarrete, N. Optimization of spray drying conditions for lulo (Solanum quitoense L.) pulp. Powder Technol. 2014, 256, 233238.

38. Vasco, C.; Ruales, J.; Kamal-Eldin, A. Total phenolic compounds and antioxidant capacities of major fruits from Ecuador. Food Chem. 2008, 111, 816-823.

39. Nagar, E.; Berenshtein, L.; Okun, Z.; Shpigelman, A. The structure-dependent influence of high pressure processing on polyphenol-cell wall material (CWM) interactions and polyphenol-polyphenol association in model systems: Possible implication to accessibility. Innov. Food Sci. Emerg. Technol. 2020, 66, 102538.

40. Suárez-Jacobo, Á.; Rüfer, C.E.; Gervilla, R.; Guamis, B.; Roig-Sagués, A.X.; Saldo, J. Influence of ultra-high pressure homogenisation on antioxidant capacity, polyphenol and vitamin content of clear apple juice. Food Chem. 2011, 127, 447-454.

41. Velázquez-Estrada, R.M.; Hernández-Herrero, M.M.; Rüfer, C.E.; Guamis-López, B.; RoigSagués, A.X. Influence of ultra high pressure homogenization processing on bioactive compounds and antioxidant activity of orange juice. Innov. Food Sci. Emerg. Technol. 2013, 18, 89-94.

42. Minatel, I.O.; Borges, C.V.; Ferreira, M.I.; Gomez, H.A.G.; Chen, C.-Y.O.; Lima, G.P.P. Phenolic Compounds: Functional Properties, Impact of Processing and Bioavailability. In Phenolic Compounds-Biological Activity; Soto-Hernandez, M., Palma-Tenango, M., del Rosario Garcia Mateos, M., Eds.; InTech: Nappanee, IN, USA, 2017. 
43. Persic, M.; Mikulic-Petkovsek, M.; Slatnar, A.; Veberic, R. Chemical composition of apple fruit, juice and pomace and the correlation between phenolic content, enzymatic activity and browning. LWT-Food Sci. Technol. 2017, 82, 23-31.

44. Capanoglu, E.; De Vos, R.C.H.; Hall, R.D.; Boyacioglu, D.; Beekwilder, J. Changes in polyphenol content during production of grape juice concentrate. Food Chem. 2013, 139, 521-526.

45. Morais, M.G.; Saldanha, A.A.; Costa Rodrigues, J.P.; Cotta Mendes, I.; Ferreira, L.M.; Avelar Amado, P.; de Souza Farias, K.; Samúdio Santos Zanuncio, V.; Brentan da Silva, D.; Carmo Horta Pinto, F.; et al. Chemical composition, antioxidant, anti-inflammatory and antinociceptive activities of the ethanol extract of ripe fruits of Solanum lycocarpum St. Hil. (Solanaceae). J. Ethnopharmacol. 2020, 262, 113125.

46. More, G.K. A review of the ethnopharmacology, phytochemistry and pharmacological relevance of the South African weed Solanum sisymbriifolium Lam. (Solanaceae). Environ. Dev. Sustain. 2019, 21, 37-50.

47. Rios, R.; da Silva, H.B.F.; Carneiro, N.V.Q.; Pires, A.d.O.; Carneiro, T.C.B.; Costa, R.d.S.; Marques, C.R.; Machado, M.S.S.; Velozo, E.d.S.; Silva, T.M.G.d.; et al. Solanum paniculatum $L$. decreases levels of inflammatory cytokines by reducing NFKB, TBET and GATA3 gene expression in vitro. J. Ethnopharmacol. 2017, 209, 32-40.

48. Da Costa, G.A.F.; Morais, M.G.; Saldanha, A.A.; Assis Silva, I.C.; Aleixo, Á.A.; Ferreira, J.M.S.; Soares, A.C.; Duarte-Almeida, J.M.; Lima, L.A.R.D.S. Antioxidant, Antibacterial, Cytotoxic, and Anti-Inflammatory Potential of the Leaves of Solanum lycocarpum A. St. Hil. (Solanaceae). Evid.-based Complement. Altern. Med. 2015, 2015.

49. Ismail, B.B.; Pu, Y.; Guo, M.; Ma, X.; Liu, D. LC-MS/QTOF identification of phytochemicals and the effects of solvents on phenolic constituents and antioxidant activity of baobab (Adansonia digitata) fruit pulp. Food Chem. 2019, 277, 279-288.

50. Pinela, J.; Montoya, C.; Carvalho, A.M.; Martins, V.; Rocha, F.; Barata, A.M.; Barros, L.; Ferreira, I.C.F.R. Phenolic composition and antioxidant properties of ex-situ conserved tomato (Solanum lycopersicum L.) germplasm. Food Res. Int. 2019, 125, 108545.

51. Díaz-García, M.C.; Obón, J.M.; Castellar, M.R.; Collado, J.; Alacid, M. Quantification by UHPLC of total individual polyphenols in fruit juices. Food Chem. 2013, 138, 938-949.

52. Brahem, M.; Renard, C.M.G.C.; Eder, S.; Loonis, M.; Ouni, R.; Mars, M.; Le Bourvellec, C. Characterization and quantification of fruit phenolic compounds of European and Tunisian pear cultivars. Food Res. Int. 2017, 95, 125-133.

53. Kolniak-Ostek, J. Content of bioactive compounds and antioxidant capacity in skin tissues of pear. J. Funct. Foods 2016, 23, 40-51.

54. Chanforan, C.; Loonis, M.; Mora, N.; Caris-Veyrat, C.; Dufour, C. The impact of industrial processing on health-beneficial tomato microconstituents. Food Chem. 2012, 134, 17861795.

55. Gómez-Romero, M.; Segura-Carretero, A.; Fernández-Gutiérrez, A. Metabolite profiling and quantification of phenolic compounds in methanol extracts of tomato fruit. Phytochemistry 2010, 71, 1848-1864.

56. Hokkanen, J.; Mattila, S.; Jaakola, L.; Pirttilä, A.M.; Tolonen, A. Identification of phenolic compounds from lingonberry (Vaccinium vitis-idaea L.), Bilberry (Vaccinium myrtillus L.) andHybrid Bilberry (Vaccinium x intermedium Ruthe L.) Leaves. J. Agric. Food Chem. 2009, 57, 9437-9447. 
57. Park, J.B. 5-Caffeoylquinic acid and caffeic acid orally administered suppress P-selectin expression on mouse platelets. J. Nutr. Biochem. 2009, 20, 800-805.

58. Pereira, A.P.A.; Angolini, C.F.F.; Paulino, B.N.; Lauretti, L.B.C.; Orlando, E.A.; Silva, J.G.S.; Neri-Numa, I.A.; Souza, J.D.R.P.; Pallone, J.A.L.; Eberlin, M.N.; et al. A comprehensive characterization of Solanum lycocarpum St. Hill and Solanum oocarpum Sendtn: Chemical composition and antioxidant properties. Food Res. Int. 2018, 1-9.

59. Gutiérrez Ortiz, A.L.; Berti, F.; Navarini, L.; Monteiro, A.; Resmini, M.; Forzato, C. Synthesis of p-coumaroylquinic acids and analysis of their interconversion. Tetrahedron Asymmetry 2017, 28, 419-427.

60. Mikulic-Petkovsek, M.; Schmitzer, V.; Jakopic, J.; Cunja, V.; Veberic, R.; Munda, A.; Stampar, F. Phenolic compounds as defence response of pepper fruits to Colletotrichum coccodes. Physiol. Mol. Plant Pathol. 2013, 84, 138-145.

61. Rodríguez-Medina, I.C.; Segura-Carretero, A.; Fernández-Gutiérrez, A. Use of highperformance liquid chromatography with diode array detection coupled to electrosprayQq-time-of-flight mass spectrometry for the direct characterization of the phenolic fraction in organic commercial juices. J. Chromatogr. A 2009, 1216, 4736-4744,

62. Liu, P.; Li, L.; Song, L.; Sun, X.; Yan, S.; Huang, W. Characterisation of phenolics in fruit septum of Juglans regia Linn. by ultra performance liquid chromatography coupled with Orbitrap mass spectrometer. Food Chem. 2019, 286, 669-677.

63. Dorta, E.; González, M.; Lobo, M.G.; Sánchez-Moreno, C.; de Ancos, B. Screening of phenolic compounds in by-product extracts from mangoes (Mangifera indica L.) by HPLCESI-QTOF-MS and multivariate analysis for use as a food ingredient. Food Res. Int. 2014, 57, 51-60.

64. Fu, L.; Xu, B.T.; Xu, X.R.; Gan, R.Y.; Zhang, Y.; Xia, E.Q.; Li, H. Bin Antioxidant capacities and total phenolic contents of 62 fruits. Food Chem. 2011, 129, 345-350.

65. Phenol-Explorer; USA Database Phenol-Explorer. Available online: http://phenolexplorer.eu/compounds (accessed on 18 February 2020).

66. Baret, P.; Septembre-Malaterre, A.; Rigoulet, M.; Lefebvre d'Hellencourt, C.; Priault, M.; Gonthier, M.-P.; Devin, A. Dietary polyphenols preconditioning protects 3T3-L1 preadipocytes from mitochondrial alterations induced by oxidative stress. Int. J. Biochem. Cell Biol. 2013, 45, 167-174.

67. Asgary, S.; Sahebkar, A.; Afshani, M.R.; Keshvari, M.; Haghjooyjavanmard, S.; RafieianKopaei, M. Clinical Evaluation of Blood Pressure Lowering, Endothelial Function Improving, Hypolipidemic and Anti-Inflammatory Effects of Pomegranate Juice in Hypertensive Subjects. Phyther. Res. 2014, 28, 193-199.

68. Wu, S.B.; Meyer, R.S.; Whitaker, B.D.; Litt, A.; Kennelly, E.J. A new liquid chromatographymass spectrometry-based strategy to integrate chemistry, morphology, and evolution of eggplant (Solanum) species. J. Chromatogr. A 2013, 1314, 154-172.

69. Santiago-Silva, P.; Labanca, R.A.; Gloria, M.B.A. Functional potential of tropical fruits with respect to free bioactive amines. Food Res. Int. 2011, 44, 1264-1268.

70. Bomtempo, L.L.; Costa, M.A.; Lima, H.; Engeseth, N.; Gloria, M.B.A. Bioactive amines in Passiflora are affected by species and fruit development. Food. Res. Int. 2016, 89, 733738. 


\section{Características microestructurales del tejido de lulo}

\section{Introducción}

Tal y como se ha dicho en la introducción, el fruto del lulo (Solanum quitoense Lam) tiene una estructura interna similar a la del fruto del tomate. Se compone de diferentes partes: la cáscara (exocarpio), la pulpa (mesocarpio y endocarpio) y los tejidos placentarios (placenta, gel locular y semillas) (Figura 3.7). El tejido que constituye la pulpa (mesocarpio y endocarpio), de color verde-amarillenta o naranja brillante según el estado de madurez, forma cuatro compartimentos separados por tabiques membranosos donde se alojan los tejidos placentarios. Los tejidos placentarios, la pulpa y la cáscara representan el $57 \%$, el $38 \%$ y el $5 \%$, respectivamente, del peso total del fruto.

Esta estructura interna del fruto, de la que las semillas se separan con dificultad, es la que hace que rara vez el fruto se consuma en fresco, y que se utilice sobre todo para elaborar bebidas aromatizadas, conservas y postres.

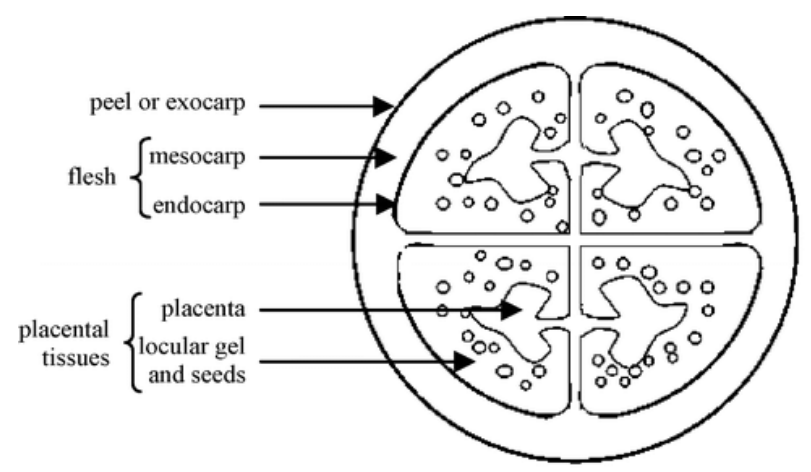

Figura 3.7. Esquema de una sección transversal del fruto de la naranjilla [1].

El contenido en fenoles totales y en carotenoides varía en las diferentes partes del fruto: los mayores valores se encuentran en la piel, seguidos por la pulpa, y las cantidades más bajas se encuentran en los tejidos placentarios[1]. En el proceso de obtención del zumo, las semillas y las estructuras membranosas se eliminan casi en su totalidad, perdiéndose un porcentaje considerable de compuestos fenólicos y carotenoides.

El desarrollo de procesos que permitan el consumo del fruto conservando su estructura natural, resultaría interesante para mantener todo el valor nutricional y funcional. Por ejemplo, si las características 
microestructurales (tamaño y distribución de poros y espacios intercelulares) lo permiten, la operación de impregnación a vacío de la fruta permitiría obtener productos diferentes que conservaran la composición de la fruta fresca y, además, tuvieran mayor estabilidad, vida útil y/o valor funcional.

Bajo estas premisas, se consideró interesante realizar una caracterización microestructural utilizando microscopia electrónica de barrido a bajas temperaturas (Cryo-SEM).

\section{Metodología}

Se utilizó la técnica de Cryo-SEM para obtener imágenes que proporcionaran una idea general sobre las características microestructurales del tejido del fruto del lulo. Se cortó una sección transversal correspondiente a la región del mesocarpio y otra sección transversal correspondiente a la región del endocarpio de una rodaja de un fruto de lulo. Cada una de las secciones, se montó en un portamuestras de acero inoxidable, se congeló inmediatamente en nitrógeno líquido, se recubrió de oro y se observó por SEM utilizando un microscopio JEOL, modelo JSM-5410.

\section{Resultados}

La Figura 3.8. incluye algunas de las imágenes obtenidas por Cryo SEM del mesocarpio y endocarpio del fruto fresco en el estado de madurez adecuado para el consumo. 


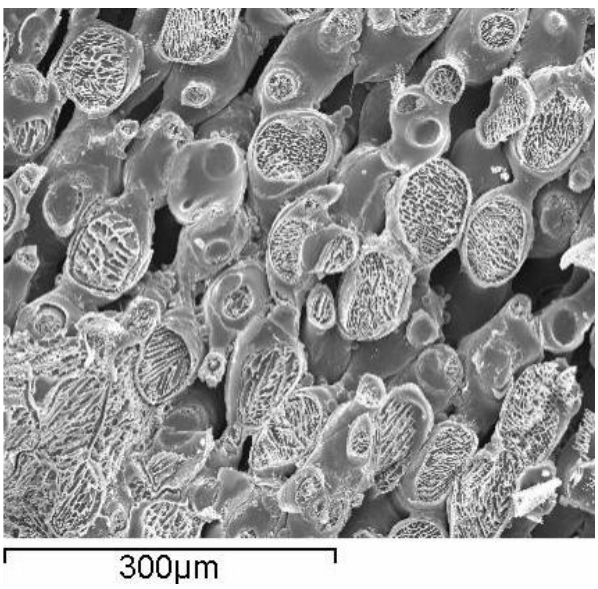

(a)

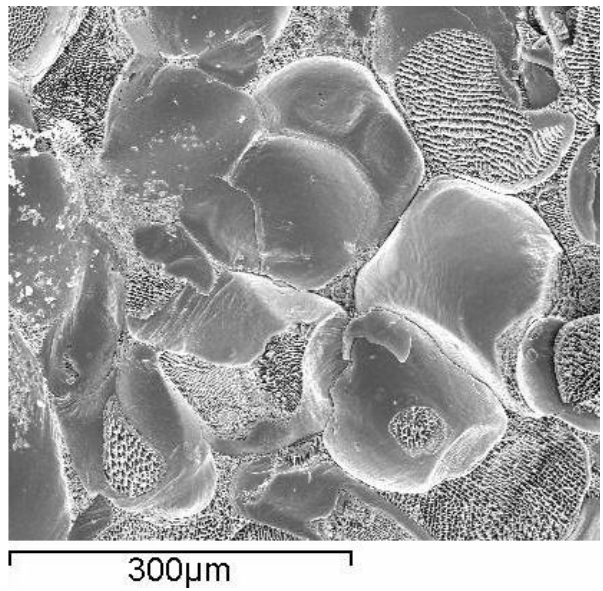

(c)

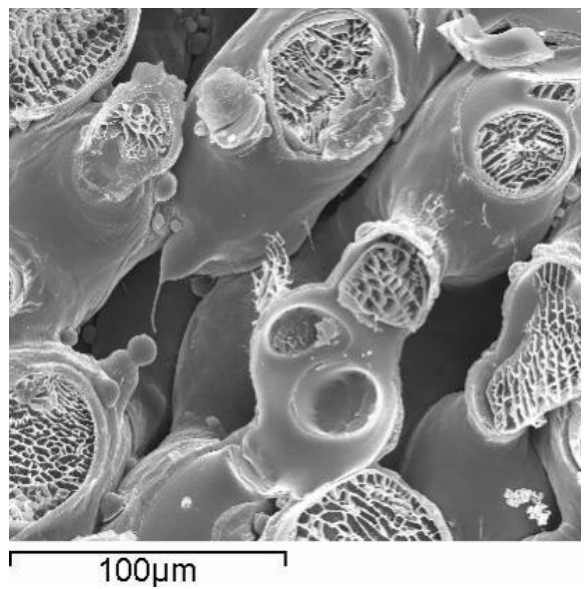

(b)

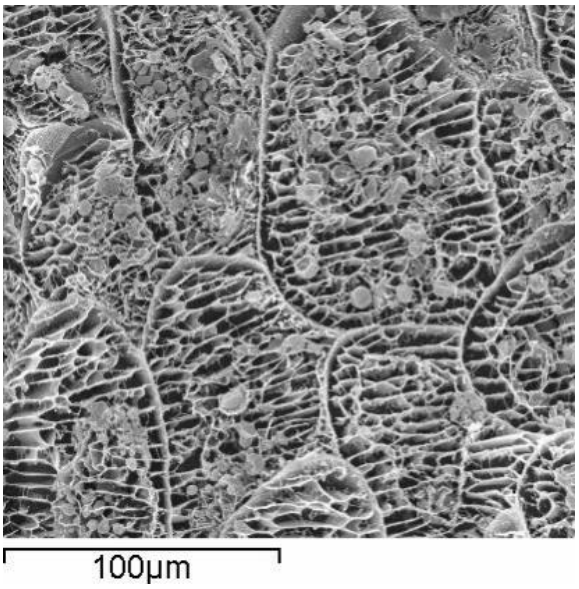

(d)

Figura 3.8. Micrografías (Cryo-SEM) del tejido del fruto de lulo fresco correspondientes al mesocarpo ((a) y (b)) y al endocarpo ((c) y (d)).

Puede observarse una configuración diferente en lo que respecta a la forma y tamaño de las células, distribución de estas, y de los poros y espacios intercelulares. Las dos zonas del tejido presentan la distribución celular de un parénquima típico de la parte comestible de las frutas. Las células parenquimáticas están poco especializadas y presentan una ligera variabilidad en su forma: las del endocarpio ((c) y (d)) son más o menos isodiamétricas y facetadas, algunas son poliédricas; las del mesocarpio ((a) y (b)) son ligeramente lobuladas. Las paredes celulares son en general delgadas, y no se observan paredes secundarias lignificadas. Además, las células del endocarpio 
((c) y (d)) son de mayor tamaño y con formas menos alargadas, configurando una distribución más compacta en el tejido, con espacios intercelulares bastante reducidos (de varios $\mu \mathrm{m}$ a varias decenas de $\mu \mathrm{m}$ ). Los espacios intercelulares, en general, se observan llenos de líquido, característica muy típica de las frutas carnosas y jugosas. Por lo que respecta a las células del mesocarpio ((a) y (b)), son de un tamaño menor y más variable, configurando un tejido más esponjoso y menos compacto en el que los espacios intercelulares son de mayor tamaño y se conectan unos con otros dando lugar a poros o huecos más abiertos que alcanzan, en muchos casos, un tamaño superior a un centenar de $\mu \mathrm{m}$. En este caso, los espacios intercelulares se encuentran llenos de aire.

Los parámetros de impregnación obtenidos en el apartado anterior demuestran que la inclusión de compuestos (componentes bioactivos, conservantes, estabilizante...) disueltos en una disolución acuosa, en la estructura porosa del tejido del fruto de lulo por impregnación a vacío, podría realizarse sin problema en una cantidad (en volumen) comprendida entre el $8,6 \%$ y el $16 \%$ (valor del parámetro $X$ obtenido por Hinestroza et al. [2]). Sin embargo, la inclusión de componentes en suspensión requeriría que tuvieran un tamaño menor al de los espacios intercelulares, huecos o poros de la estructura natural del tejido. En relación con la incorporación de probióticos del género Lactobacillus, uno de los componentes bioactivos considerados en la presente tesis doctoral, el tamaño de las células varía entre las 1,6 - 2,8 $\mu \mathrm{m}$ de longitud para las cepas más pequeñas y las $5,2-7,6 \mu \mathrm{m}$ para las cepas más grandes [3]. Si tenemos en cuenta los tamaños que se han obtenido para los espacios o huecos del tejido del fruto de lulo, puede afirmarse que estos serán incorporados fácilmente a la estructura del mesocarpio, si bien su incorporación al endocarpio podría presentar problemas.

\section{Bibliografía}

1. Gancel, A.L.; Alter, P.; Dhuique-Mayer, C.; Ruales, J.; Vaillant, F. Identifying carotenoids and phenolic compounds in naranjilla (Solanum quitoense Lam. var. Puyo hybrid), an Andean fruit. J. Agric. Food Chem. 2008, 56, 11892-11899.

2. Hinestroza-Córdoba, L.I.; Barrera, C.; Seguí, L.; Betoret, N. Potential Use of Vacuum Impregnation and High-Pressure Homogenization to Obtain Functional Products from Lulo Fruit (Solanum quitoense Lam.). Foods 2021, Vol. 10, Page 817 2021, 10, 817.

3. Rajab, S.; Tabandeh, F.; Shahraky, M.K.; Alahyaribeik, S. The effect of lactobacillus cell size on its probiotic characteristics. Anaerobe 2020, 62, 102103. 


\title{
Fermentation of Lulo Juice with Lactobacillus reuteri CECT 925. Properties and Effect of High Homogenization Pressures on Resistance to In Vitro Gastrointestinal Digestion
}

\author{
Hinestroza-Córdoba, L. I².; Seguí, Lํ; Barrera, $\mathrm{C}^{1}$.; Betoret, $\mathrm{E}^{1}$.; Betoret, $\mathrm{N}^{1}$ \\ 1 Grupo de Valoración y Aprovechamiento de la Biodiversidad, Universidad Tecnológica del \\ Chocó, AA.292, Calle 22 No. 18B-10, CP. 270002, Quibdó, Chocó, Colombia; \\ leihicor@doctor.upv.es \\ 2 Institute of Food Engineering for Development, Universitat Politècnica de València, CP \\ 46022 València, Spain; ester_betoret@hotmail.com (E.B.); lusegil@upvnet.upv.es (L.S.); \\ mcbarpu@tal.upv.es (C.B.) \\ * Correspondence: noebeval@tal.upv.es; Tel.: +34-963-877-000 (ext. 73658)
}

Applied Sciences 2021, 11(22), 10909

\begin{abstract}
The aim of this study was to evaluate the use of lulo juice as substrate for producing a potentially probiotic beverage with Lactobacillus reuteri CECT 925. Lulo juices at two pH levels and two levels of HPH treatment have been considered to evaluate the effect of these variables on Lactobacillus reuteri CECT 925 growth, physicochemical and antioxidant properties, and the resistance of microbial cells to gastrointestinal digestion in vitro. Regarding the growth of Lactobacillus reuteri CECT 925, it was mainly affected by the $\mathrm{pH}$ of the medium, the rectified juice at $\mathrm{pH} 5.5$ being the most appropriated one. The growth of Lactobacillus reuteri CECT 925 mainly increased the antiradical capacity of the juices. In general, Lactobacillus reuteri CECT 925 showed good resistance to in vitro gastrointestinal digestion conditions, reaching levels above $10^{7} \mathrm{CFU} / \mathrm{mL}$ in all cases. The highest resistance was observed in the juice treated at $150 \mathrm{MPa}$ followed by the juice homogenized at $100 \mathrm{MPa}$.
\end{abstract}

Key words: non-thermal treatment, tropical fruit juices, probiotics, functional food.

\section{Introduction}

A positive consumer attitude towards a healthy and balanced diet has been growing lately all over the world. Therefore, the demand for foods that promote health and well-being, such as functional foods containing 
phytochemicals and probiotics has increased [1]. The latest revised and accepted definition of probiotics states that they are "live microorganisms that, when administered in adequate amounts, confer a health benefit on the host" [2]. Although traditional matrices used for the incorporation of bacterial species with beneficial properties are dairy matrices, in the last decade there have been numerous studies demonstrating the interest in using plant-based matrices. In plant-based matrices, the beneficial activity and efficacy of the probiotic could be enhanced by the bioactive components naturally present in the plant matrix, resulting in a final functional product in which there is a synergistic effect on the health benefit between the bioactive components and the probiotic strain [3].

The lulo (Solanum quitoense Lam.) stands out among tropical fruits with a pleasant flavor and a distinctive nutritional and phytochemical composition. Although lulo fruit is mainly consumed as juice in the producing countries themselves, it has gained interest in national and international markets due to its organoleptic and functional properties [4]. It has a high potential for the development of functional foods; is rich in vitamin $\mathrm{C}$, fiber, and antioxidant compounds, such as all trans- $\beta$-carotene, lutein and zeaxanthin, chlorogenic acids, flavonol glycosides and bioactive amines such as $\mathrm{N}^{1}, \mathrm{~N}^{4}, \mathrm{~N}^{8}$ tris(dihydrocaffeoyl) spermidine and $\mathrm{N}^{1}, \mathrm{~N}^{8}$-bis(dihydrocaffeoyl) spermidine. Some in vitro and in vivo studies reveal various mechanisms through which the lulo compounds reduce risk or reverse metabolic- and inflammationassociated diseases [5].

Additionally, some fruit juices have been demonstrated to be a good matrix to proliferate probiotic microorganisms due to its content in carbohydrates, vitamins, and bioactive compounds. Coupled to fruit consumption, the intake of certain microorganisms is capable of decreasing body fat by modifying the intestinal microbiota, stimulating the synthesis of satiety-inducing peptides, reducing the synthesis of proinflammatory cytokines and possibly modifying the lipid profile or suppressing Helicobacter populations [6]. Therefore, tropical fruit juices fermented with probiotics may be an effective strategy to meet dietary health requirements.

However, it is known that the survival of lactic bacteria in fruit juices tends to be more complex than in dairy beverages. This is due, mainly, to the natural acidity of fruit, the high level of polyphenols and the absence of 
lactose, which may interfere in the survival of certain sorts of microorganisms, as well as in their growth and in their resistance to the gastrointestinal digestion process [7]. In this sense, the application of some pretreatments and a suitable selection of strain can improve the probiotic growth, resistance, and, consequently, their release to the specific target site.

Lactobacillus reuteri is a heterofermentative lactic acid bacterium (LAB) found in a variety of ecological niches like fermented food and the gastro-intestinal as well as the urogenital tract of humans and other animals [8]. Its consumption as a supplement has been recognized as safe [9], and some probiotic properties have been demonstrated. It was shown to inhibit Helicobacter pylori in the human stomach, thus, providing new opportunities in the treatment of chronic stomach inflammation [10]. Orally administered in combination with Lactobacillus rhamnosus enhanced vaginal flora quality and was effective against bacterial vaginosis [11,12]. Additionally, Lactobacillus reuteri showed an improve of biomarkers of inflammation and cardiovascular risk in obese adults with metabolic syndrome [13]. Lactobacillus reuteri has the capability to ferment a whole range of different carbon sources and some species have been used to ferment fruit juices producing bioactive compounds of great interest such as folates and vitamin B12 [14]. Furthermore, Lactobacillus reuteri has the capability to produce reuterin, a compound with potential as a food preservative, especially due to its activity against food spoilage microorganisms such as Listeria monocytogenes and Escherichia coli. Definitively, its features and its safe status makes it a promising microorganism in the food industry [8]. Some research works show fruit juices as a good carrier for Lactobacillus reuteri, but their viability was strongly affected by the kind of juices. Namely, Lactobacillus reuteri showed a high viability in pineapple, orange, and apple juices, while the viability was reduced in red-fruit juice [15]. In addition, thermal preservation treatments or exposure to temperatures above refrigeration also have unfavorable effects. In this sense, the viability of probiotic cells can be improved by modifying the properties of the juice after a non-thermal preservation treatment as an alternative to a conventional heat treatment.

High pressures homogenization ( $\mathrm{HPH}$ ) is a non-thermal treatment, which in addition to being used for preservation purposes, also improves the physico-chemical and functional properties of fruit juices, increasing quality, stability, and phytochemical profile $[16,17]$. It allows the replacement of 
traditional processes to better preserve sensory and nutritional characteristics, as well as to develop products with differentiated structural characteristics and functional properties [18]. The application of high and/or moderate homogenization pressures to fruit juices has proven to be less destructive for low molecular weight compounds responsible for sensory and nutritional attributes and, at the same time, sufficiently effective to inactivate the microorganisms that are responsible for spoilage [19]. Applied to strains with probiotic effect, homogenization has been shown to increase survival and improve functional properties. For example, in trials with Lactobacillus paracasei A13 strains, the application of high homogenization pressures increased their hydrophobicity, which is directly related to their ability to adhere to intestinal cells and their resistance to the digestion process [20]. Moreover, $\mathrm{HPH}$ at $50 \mathrm{MPa}$ applied to cells of Lactobacillus paracasei $\mathrm{A} 13$ were able to modulate the murine immune system inducing a high IgA response, compared to untreated cells. In fact, modifications of the outermost cellular structures by the hyperbaric treatments play an important role in the final probiotic and immune cells interaction [21].

Finally, to ensure that Lactobacillus exerts a beneficial probiotic effect on a host, it needs to survive to gastrointestinal digestion process. In vitro digestion simulation is often used to evaluate probiotic survival in the gastrointestinal tract. This technique is not only faster and less expensive than comparable methods, but also resource-efficient, with significantly lower bioethical constraints [22].

Based on all that has been stated, the aim of this study was to evaluate the use of lulo juice as substrate for producing a potentially probiotic beverage with Lactobacillus reuteri. Lulo juices at two $\mathrm{pH}$ levels and two pressures of $\mathrm{HPH}$ treatment have been considered to evaluate the effect of these variables on Lactobacillus reuteri growth, physicochemical and antioxidant properties, and the resistance of microbial cells to gastrointestinal digestion in vitro.

\section{Materials and methods}

\subsection{Raw materials}

Fresh lulo fruits (Solanum quitoense Lam.) from Colombia were purchased in the Central Market of Valencia city (Spain). Whole fruits were washed with water, blended (Phillips Advance Collection Standmixer 800W, 
$2 \mathrm{~L}$ ) and filtered through a $500 \mu \mathrm{m}$ stainless steel sieve. After sieving, the juices were subjected to a HPH treatment at 100 or $150 \mathrm{MPa}$, using a laboratoryscale high-pressure homogenizer (Gea Niro Soavi-Panda Plus 2000, Parma, Italy). Then, both the non-homogenized juice and the juices homogenized at 100 or $150 \mathrm{MPa}$ were pasteurized for $3 \mathrm{~min}$ at $72{ }^{\circ} \mathrm{C}$. After the thermal treatment, the juices were kept refrigerated at $4{ }^{\circ} \mathrm{C}$ for $24 \mathrm{~h}$ until further inoculation and after that, frozen until analysis.

Lactobacillus reuteri CECT 925 (animal origin) from the Spanish Type Culture Collection (Parc Científic de la Universitat de València) was used as probiotic strain. The freeze-dried strain was incubated in commercial MRS broth (Scharlau Chemie ${ }^{\circ}$, Barcelona, Spain) in $100 \mathrm{~mL}$ Erlenmeyer flasks for 24 $\mathrm{h}$ at $37^{\circ} \mathrm{C}$ in static conditions. Lactobaciullus reuteri reached a growth of $1.6 \pm$ $0.2 \times 10^{9} \mathrm{CFU} / \mathrm{mL}$ in MRS broth and it was kept refrigerated for $24 \mathrm{~h}$ until its use as starter inoculum.

\subsection{Preparation of lulo juice with Lactobacillus reuteri CECT 925}

To ensure an appropriate growth of Lactobacillus reuteri CECT 925 in lulo juice and in accordance with previous studies [19], the $\mathrm{pH}$ of the juice was rectified to $\mathrm{pH} 5.5$ and 6 using sodium bicarbonate. In addition, yeast extract (Scharlau Chemie ${ }^{\circ}$, Barcelona, Spain) was added in an amount of $5 \mathrm{~g} / \mathrm{L}$. The juice was contained in clear borosilicate glass 3.3 bottles, GL45 threaded, 250 $\mathrm{mL}$, with blue stopper and pouring ring, ISO 4796 (Scharlau Chemie ${ }^{*}$, Barcelona, Spain). The strain was transferred from the MRS broth to the juices (non-homogenized juice, juice homogenized at $100 \mathrm{MPa}$ and homogenized at $150 \mathrm{MPa}$ ) in an amount of $4 \mathrm{~mL} / \mathrm{L}$. The bottles were completely filled and capped. Subsequently, the juices were incubated at $37{ }^{\circ} \mathrm{C}$ for $24 \mathrm{~h}$ in static conditions. Fermentation was carried out in triplicate.

\subsection{Analytical determinations}

All the analytical determinations were carried out at least in triplicate on the juices before inoculation and after incubation.

The $\mathrm{pH}$ values were obtained using a digital $\mathrm{pH}$-meter (Mettler Toledo Inlab, Schwerzenbach, Switzerland), calibrating the equipment prior to analysis with buffer solutions at pHs 7 and 4 . 
Soluble solids content was determined with a refractometer (Abbe Atago BT, Nar T3, Tokyo, Japan), previously calibrated with distilled water and thermostated at $20^{\circ} \mathrm{C}$, by direct reading of their refractive indexes in Brix [23].

Density was measured with Bingham $25 \mathrm{~mL}$ pycnometer, for density and relative density determination in liquids (ASTM D1217, Scharlau Chemie ${ }^{\circ}$, Barcelona, Spain) at room temperature $\left(20-22^{\circ} \mathrm{C}\right)$ and distilled water as the reference liquid [24].

Suspended pulp and cloudiness were determined following the methodology described by Betoret et al. [25], according to which the suspended pulp of a juice is equivalent to the volume of the precipitate obtained after centrifugation (Medefriger BL-S P-Select centrifuge) of $10 \mathrm{~mL}$ of sample at $365 \times g$ (for unstable pulp) or $3000 \times g$ (for stable pulp) at $25^{\circ} \mathrm{C}$ for $10 \mathrm{~min}$. The turbidity of the samples corresponds to the transmittance of the supernatant obtained after centrifugation, measured at $650 \mathrm{~nm}$ in a UV/Visible spectrophotometer (Thermo Scientific Helios Zeta U/Vis, Loughborough, UK).

Particle size distribution was determined with the Malvern Mastersizer 2000 (Malvern Instruments Limited, Worcestershire, UK), equipped with a $470 \mathrm{~nm}$ blue light source and a 0.02-200 micron measuring range. The refractive index of the juices (cloud) and the dispersant (water) were set at 1.5 and 1.33, respectively. Absorption of the cloud particles was taken as 0.1. Particle size distribution of the juices was characterized by both volume $(D[4,3])$ and area $(D[3,2])$ equivalent diameters, and by the percentiles $\mathrm{d} 10, \mathrm{~d} 50$, and $\mathrm{d} 90$, which correspond to the characteristic diameters below which $10 \%, 50 \%$, and $90 \%$ of the particles are included in the distribution [26].

CIE* $L^{*} a * b *$ color coordinates were determined from the surface reflectance spectra obtained between 400 and $700 \mathrm{~nm}$. The equipment was calibrated on white and black backgrounds, considering standard light source D65 and observer $10^{\circ}$ (Minolta spectrophotometer CM-3600d, Osaka, Japan). The resulting $\mathrm{CIE}-\mathrm{L}^{*} \mathrm{a}^{*} \mathrm{~b}^{*}$ color coordinates allowed calculating the psychometric coordinates: tone $\left(\mathrm{h}^{*}{ }_{\mathrm{ab}}\right)$ and chrome $\left(\mathrm{C}^{*}{ }_{\mathrm{ab}}\right)$ according to $\mathrm{CIE}$ [27].

Antioxidant properties. For antioxidants extraction, the samples were mixed with an 80:20 ( $/ v / v)$ methanol-water solution at a 1:10 ratio $(w / v)$, stirred for $1 \mathrm{~h}$ using a magnetic device (RTC basic, Staufen, Germany), and 
centrifuged at $10,000 \mathrm{rpm}$ and $20{ }^{\circ} \mathrm{C}$ for $5 \mathrm{~min}$ (Medefriger BL-S P-Select centrifuge). Subsequent analyses (total phenols and flavonoids and antiradical capacity) were carried out on the supernatant.

Total phenols were determined following the Folin-Ciocalteu method $[28,29]$, by mixing $0.125 \mathrm{~mL}$ of juice, $0.125 \mathrm{~mL}$ of Folin-Ciocalteu reagent (Sigma-Aldrich) and $0.5 \mathrm{~mL}$ of double-distilled water. This solution was allowed to react for $6 \mathrm{~min}$. Next, $1.25 \mathrm{~mL}$ of $7 \%(\mathrm{~m} / \mathrm{v})$ sodium carbonate solution and $1 \mathrm{~mL}$ of double distilled water were added. Absorbance was measured at 765 $\mathrm{nm}$ in a spectrophotometer (Thermo Scientific Helios Zeta U/Vis, Loughborough, UK). A reference blank was prepared, wherein the sample was replaced by the same amount of double distilled water and was allowed to react for $90 \mathrm{~min}$. A standard gallic acid curve ranging from 0 to $500 \mathrm{mg} / \mathrm{L}$ was obtained to express the results in milligrams of gallic acid equivalent (GAE) per $\mathrm{mL}$.

Flavonoids content was determined following methodology described by Luximon-Rama et al. [30]. This was done by mixing $5 \mathrm{~mL}$ of juice and $1.5 \mathrm{~mL}$ of a $2 \%(w / v)$ aluminum chloride solution, which was left in the dark for 10 min. Absorbance was measured at $368 \mathrm{~nm}$ in a spectrophotometer (Thermo Scientific Helios Zeta U/Vis, Loughborough, UK). The data obtained were compared to a standard quercetin curve ranging from 0 to $350 \mathrm{mg} / \mathrm{L}$. The results were expressed in milligrams of quercetin equivalent (EQ) per $\mathrm{mL}$.

Antiradical capacity was determined following the $\operatorname{DPPH}^{\cdot}(2,2$ diphenyl-1-picrylhydrazyl) method, as described by Kuskoski et al. and Stratil et al. [31,32], with some modifications. A solution with $0.1 \mathrm{~mL}$ of juice, $0.9 \mathrm{~mL}$ of methanol, and $2 \mathrm{~mL}$ of a $100 \mu \mathrm{M}$ methanol-DPPH $(39.4 \mu \mathrm{g} / \mathrm{mL})$ solution was prepared. After 0,30 , and 60 min of reaction, absorbance was measured at $517 \mathrm{~nm}$ in a spectrophotometer (Thermo Scientific Helios Zeta U/Vis, Loughborough, UK). The results were expressed as milligrams of Trolox equivalent (TE) per $\mathrm{mL}$, using the Trolox calibration curve within a 0 to 500 $\mathrm{mg} / \mathrm{L}$ concentration range.

Antiradical capacity was also evaluated following the ABTS $+\left(2,2^{\prime}\right.$ azino-bis-3 ethylbenzothiazoline-6-sulfonic acid) method as described by $\mathrm{Re}$ et al. [33]. A solution containing $7 \mathrm{mM}$ of ABTS and $2.45 \mathrm{mM}$ of potassium persulfate was prepared and left in the dark at room temperature for $16 \mathrm{~h}$. ABTS was mixed with phosphate buffer to reach an absorbance of $0.70 \pm 0.02$, 
which was read at $734 \mathrm{~nm}$. A $0.1 \mathrm{~mL}$ aliquot of sample was added to $2.9 \mathrm{~mL}$ of ABTS solution. Absorbance was measured at $734 \mathrm{~nm}$ in a spectrophotometer (Thermo Scientific Helios Zeta U/Vis, Loughborough, UK) after 0, 3, and $7 \mathrm{~min}$ of reaction time. The results were expressed as $\mathrm{mg}$ of Trolox equivalent (TE) per $\mathrm{mL}$.

\subsection{In vitro simulation of gastrointestinal digestion}

To study the resistance of Lactobacillus reuteri CECT 925 throughout gastrointestinal digestion process, fermented lulo juices were subjected to an in vitro gastrointestinal digestion, following the standard protocol proposed by Minekus et al. [22].

Figure 1 shows the flow diagram followed in this assay, the salts used, and the volumes needed to prepare the stock solutions of the simulated fluid phases.

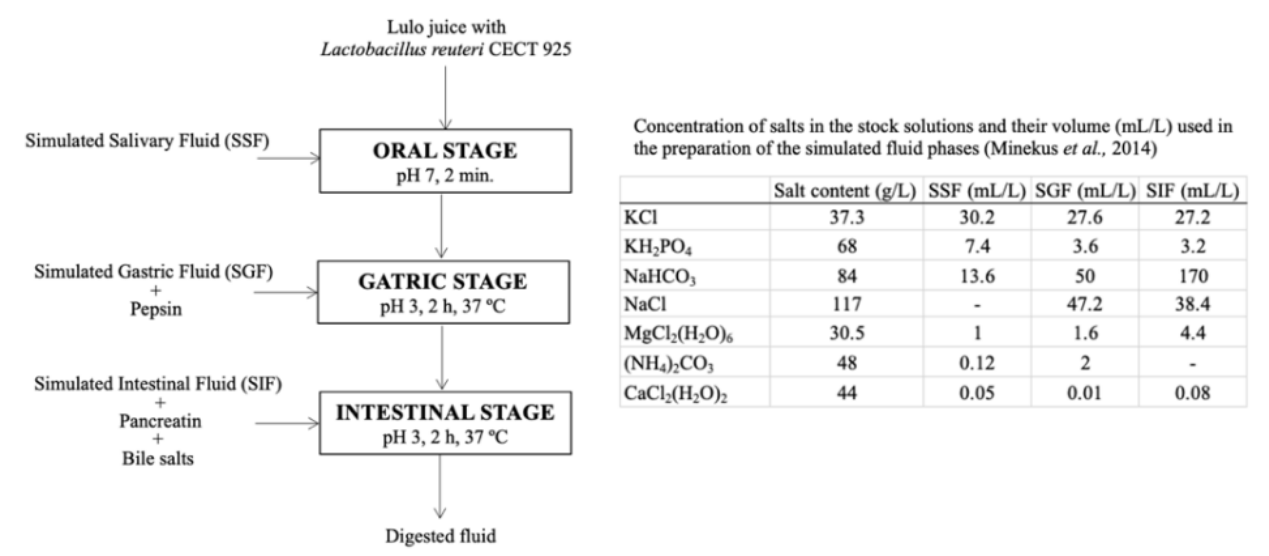

Figure 1. Stages, conditions, salts used, and the volumes needed to prepare the stock solutions of the simulated fluid phases in the simulated gastrointestinal digestion.

In each stage, the previously digested phase (lulo juice in the oral stage) and the associated simulated fluid were mixed in a ratio $1: 1(v / v)$ and kept in stirring (Intell-Mixter RM-2 Elmi Itd, Riga, LV-1006, Letino, Italy) at 55 rpm until the end of stage. The quantity of enzymes used (pepsin in the gastric stage and pancreatin in the intestinal stage) was calculated according to the enzymatic activity to ensure $20,000 \mathrm{U} / \mathrm{mL}$ of pepsin and $100 \mathrm{U} / \mathrm{mL}$ of pancreatin. $\mathrm{NaOH}(1 \mathrm{M})$ and $\mathrm{HCl}(6 \mathrm{M})$ were used for $\mathrm{pH}$ adjustment.

Viable microbial counts were performed on four samples obtained throughout the simulated digestion: at the beginning and at the end of the 
gastric stage, and at the beginning and at the end of the intestinal phase. In addition, antioxidant properties were determined at the end of the whole process.

\subsection{Microbial counts}

Colony counts were measured by serial decimal dilution in PBS, $10 \mathrm{X}$ solution (Scharlau Chemie ${ }^{\circledR}$, Barcelona, Spain) and aliquots of $1 \mathrm{~mL}$ of proper dilutions were plated on MRS Agar (Scharlau Chemie ${ }^{\circledR}$ Barcelona, Spain) [34]. The plates were incubated in anaerobiosis at $37{ }^{\circ} \mathrm{C}$ for $24 \mathrm{~h}$. Survival rate (Rs) of the microbial strain to each stage of the in vitro gastrointestinal digestion was then calculated as the ratio between the microbial concentration at the end of the stage and the microbial concentration at the end of the previous one, both referred to the same basis.

\subsection{Statistical analysis}

All determinations were made in triplicate. The statistical analysis of the data was performed in a Statgraphics Centurion XVII software package, making use of a simple or multifactorial analysis of variance (ANOVA) at a 95\% confidence level ( $p \leq 0.05)$. Significant differences $(p \leq 0.05)$ among groups were determined using the Fisher LSD test.

\section{Results}

3.1. Lactobacillus reuteri CECT 925 growth in lulo juices at different $\mathrm{pH}$ and homogenization pressures. Effect on physicochemical and antioxidant properties.

A multifactorial analysis of variance revealed a significant effect of $\mathrm{pH}$ $(p \leq 0.05)$. Viable cell counts in the juices showed values above $8(\log \mathrm{CFU} / \mathrm{mL})$ in all samples and above 9.5 in the juices at $\mathrm{pH}$ 5.5. HPH treatment had no significant effect $(p \leq 0.05)$ on the viable cell counts when compared to that achieved in the non-homogenized samples. Results are shown in Figure 2. 


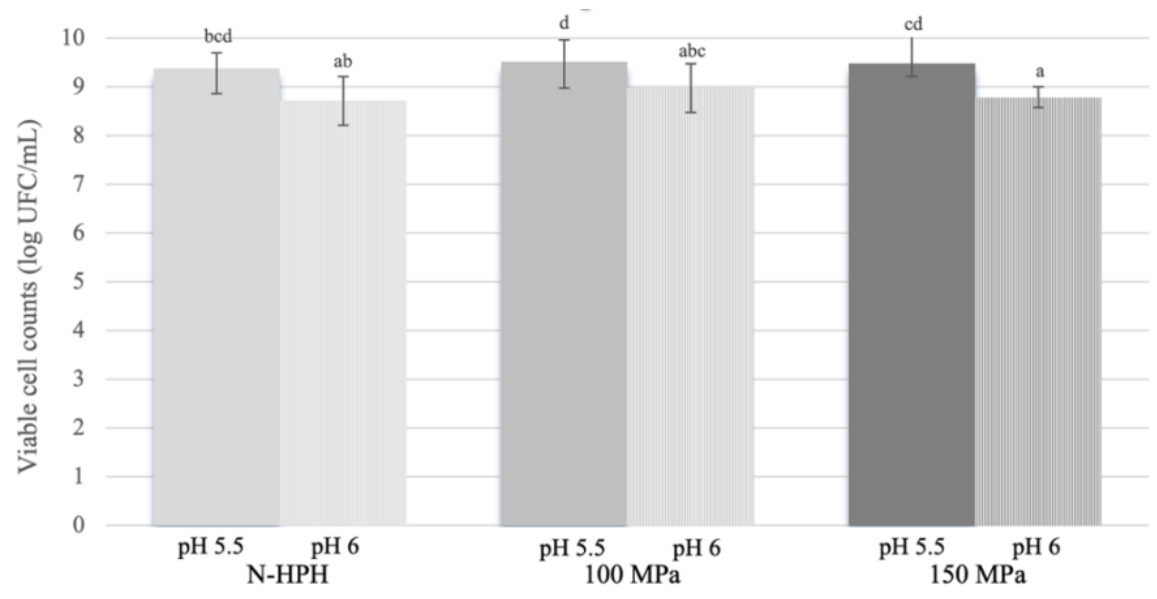

Figure 2. Impact of $\mathrm{pH}$ value and high homogenization pressures on survival of Lactobacillus reuteri CECT 925 in lulo juices after fermentation. Different letters denote significant differences $(p \leq 0.05)$.

In relation to physicochemical properties such as $\mathrm{pH}$ and soluble solids content (Brix), the influence of HPH depends on the food product. Zhou et al. [35] found no significant changes in $\mathrm{pH}$ and soluble solids content of mango juice after $\mathrm{HPH}$ at pressures up to $190 \mathrm{MPa}$. Patrignani et al. [20] found no effect of $\mathrm{HPH}$ at $100 \mathrm{MPa}$ on $\mathrm{pH}$ of carrot juice, while a decrease of $\mathrm{pH}$ of apricot juice after the same HPH treatment was observed. In this research, the application of the HPH treatment significantly decreased the Brix of the nonfermented juices (Table 1). As expected, fermentation was the most important variable decreasing both $\mathrm{pH}$ and soluble solids content. This decrease was more pronounced in the juices at $\mathrm{pH} 6$ where $\mathrm{pH}$ rectification provided a higher initial value for Brix.

The growth of Lactobacillus reuteri was the only variable that significantly influenced the density of the juices, slightly raising its value. 
Table 1. Physicochemical properties, before and after fermentation, of lulo juices at $\mathrm{pH} 5.5$ and 6 , non-homogenized and homogenized at 100 $\mathrm{MPa}$ and $150 \mathrm{MPa}$.

\begin{tabular}{|c|c|c|c|c|c|c|c|c|c|}
\hline & & & $\mathrm{pH}$ & Brix & $\rho\left(\mathrm{g} / \mathrm{cm}^{3}\right)$ & \% Pulp 365g & Transmitance 365g & \% Pulp 3000g & Transmitance 3000g \\
\hline \multirow{9}{*}{ 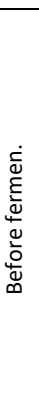 } & & pH 5.5 & $5.53 \pm 0.01^{g}$ & $8.33 \pm 0.12^{f g}$ & $1.048 \pm 0.011^{\mathrm{a}}$ & $2.79 \pm 0.17^{\text {cd }}$ & $13.7 \pm 2.2^{\mathrm{a}}$ & $1.13 \pm 0.03^{c}$ & $51.3 \pm 0.6^{b}$ \\
\hline & $\mathrm{N}-\mathrm{HPH}$ & & & & & & & & \\
\hline & & $\mathrm{pH} 6$ & $6.04 \pm 0.01^{h}$ & $8.97 \pm 0.06^{i}$ & $1.055 \pm 0.007^{\mathrm{ab}}$ & $3.3 \pm 0.3^{e}$ & $13 \pm 3^{\mathrm{a}}$ & $1.35 \pm 0.11^{\mathrm{ef}}$ & $49.2 \pm 0.5^{b}$ \\
\hline & & pH 5.5 & $5.52 \pm 0.01^{f}$ & $8.43 \pm 0.12^{\mathrm{g}}$ & $1.071 \pm 0.015^{\mathrm{ab}}$ & $2.8 \pm 0.3^{c d}$ & $16.7 \pm 2^{\mathrm{ab}}$ & $1.41 \pm 0.07^{f}$ & $64 \pm 2^{d}$ \\
\hline & $100 \mathrm{MPa}$ & & & & & & & & \\
\hline & & $\mathrm{pH} 6$ & $6.12 \pm 0.01^{i}$ & $8.67 \pm 0.15^{\mathrm{h}}$ & $1.062 \pm 0.011^{\mathrm{ab}}$ & $2.28 \pm 0.14^{\mathrm{b}}$ & $12.64 \pm 0.12^{\mathrm{a}}$ & $1.34 \pm 0.10^{f}$ & $54.7 \pm 0.5^{c}$ \\
\hline & & pH 5.5 & $5.51 \pm 0.01^{f}$ & $8.07 \pm 0.06^{\mathrm{de}}$ & $1.061 \pm 0.017^{\mathrm{ab}}$ & $2.34 \pm 0.08^{b}$ & $12.6 \pm 2.2^{\mathrm{a}}$ & $1.07 \pm 0.06^{c}$ & $54.6 \pm 0.6^{c}$ \\
\hline & $150 \mathrm{MPa}$ & & & & & & & & \\
\hline & & $\mathrm{pH} 6$ & $6.21 \pm 0.01^{j}$ & $8.17 \pm 0.06^{e f}$ & $1.05 \pm 0.03^{a}$ & $2.24 \pm 0.03^{b}$ & $22 \pm 2^{c}$ & $0.82 \pm 0.06^{b}$ & $74 \pm 2^{f}$ \\
\hline \multirow{8}{*}{ 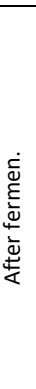 } & & pH 5.5 & $4.81 \pm 0.01^{\mathrm{a}}$ & $7.93 \pm 0.12^{\text {cd }}$ & $1.074 \pm 0.001^{\mathrm{ab}}$ & $3.0 \pm 0.3^{\mathrm{de}}$ & $19 \pm 5^{b c}$ & $1.11 \pm 0.07^{c}$ & $72.5 \pm 1.1^{f}$ \\
\hline & $\mathrm{N}-\mathrm{HPH}$ & $\mathrm{pH} 6$ & $5.19+0.01^{d}$ & $8.33+0.15^{\mathrm{fg}}$ & $1.08+0.04^{b}$ & $2.42+0.13^{b}$ & $14.1 \pm 0.6^{a}$ & $1.16+0.05^{\mathrm{cd}}$ & $65 \pm 0.95^{d}$ \\
\hline & & & & & & & & & \\
\hline & & pH 5.5 & $4.86 \pm 0.01^{b}$ & $7.80 \pm 0.02^{\mathrm{bc}}$ & $1.069 \pm 0.012^{\mathrm{ab}}$ & $3.16 \pm 0.01^{\mathrm{e}}$ & $20 \pm 2^{\mathrm{bc}}$ & $1.56 \pm 0.02^{\mathrm{g}}$ & $80.8 \pm 0.97^{g}$ \\
\hline & $100 \mathrm{MPa}$ & $\mathrm{pH} 6$ & $5.23+0.01^{e}$ & $8.03+0.06^{\mathrm{de}}$ & $1.073+0.009^{\mathrm{ab}}$ & $2.54+0.18^{b c}$ & $14.2 \pm 0.2^{\mathrm{a}}$ & $1.39+0.07^{f}$ & $38+2^{a}$ \\
\hline & & pH 5.5 & $4.96 \pm 0.01^{c}$ & $7.6 \pm 0.12^{\mathrm{a}}$ & $1.072 \pm 0.016^{\mathrm{ab}}$ & $2.75 \pm 0.01^{c d}$ & $22.7 \pm 0.4^{c}$ & $1.27 \pm 0.07^{\mathrm{de}}$ & $69.2 \pm 1.4^{\mathrm{e}}$ \\
\hline & $150 \mathrm{MPa}$ & & & & & & & & \\
\hline & & pH 6 & $5.24 \pm 0.01^{\mathrm{e}}$ & $7.7 \pm 0.13^{\mathrm{ab}}$ & $1.063 \pm 0.004^{\mathrm{ab}}$ & $1.28 \pm 0.11^{\mathrm{a}}$ & $32 \pm 2^{d}$ & $0.67 \pm 0.02^{\mathrm{a}}$ & $83.8 \pm 1.1^{h}$ \\
\hline
\end{tabular}

Values with different superscript letters in a column are significantly different $(p \leq 0.05)$. 
Pulp sedimented and transmittance of supernatant at two centrifugation speeds were measured to evaluate physical stability. According to Stokes Law, the sedimentation velocity of spherical and rigid particles is proportional to the particle size (diameter) and inversely proportional to the dispersed medium viscosity [36]. Therefore, particle size reduction due to HPH contributes to the delay of juice cloud loss by decreasing the particle's Stokes diameter and, thus, slowing down the pulp sedimentation and improving physical stability [37]. It is important to note that the possibility of increasing physical stability by employing $\mathrm{HPH}$ is very interesting for fruit juices since there will be no need for hydrocolloids or other stabilizer addition.

The results of pulp content and transmittance at the two centrifugation speeds show a higher percentage of pulp at $365 \times g$ and a higher transmittance at $3000 \times g$. The lower centrifugation speed allows the less stable and larger particles to settle while keeping the smaller particles in suspension. The smaller particles will sediment at $3000 \times g$, considerably increasing the transmittance of the supernatant.

Fermentation did not affect the percentage of pulp but did increase the transmittance especially in the samples treated at $150 \mathrm{MPa}$ (e.g., $22.7 \pm$ $0.4>13 \pm 2$ or $83.8 \pm 1.1>74 \pm 2$ ). In the samples homogenized at $100 \mathrm{MPa}$, the effect was small at low centrifugation speeds and non-existent at higher speeds.

Both $\mathrm{pH}$ and homogenization pressure had a significant effect on suspended pulp and turbidity at the two centrifugation speeds. However, the way in which the HPH affected both variables was conditioned by the $\mathrm{pH}$ of the juice. At pH 5.5, the centrifugation speed of $365 \times g$ did not allow to detect the changes that the application of $100 \mathrm{MPa}$ caused in the suspended pulp and turbidity (e.g., $2.79 \pm 0.17 \approx 2.8 \pm 0.3$ ). However, increasing the centrifugation speed did detect an increase in the percentage of settled pulp $(1.13 \pm 0.03<$ $1.41 \pm 0.07)$ and in the transmittance of the supernatant $(51.3 \pm 0.6<64 \pm 2)$. The application of a $\mathrm{HPH}$ of $150 \mathrm{MPa}$ did induce detectable changes at both centrifugation speeds. It appears that the changes induced by the $100 \mathrm{MPa}$ pressure occurred on the more stable pulp and, therefore, require a higher centrifugation speed to be detected. However, when the $150 \mathrm{MPa}$ pressure is applied, the percentage of pulp decreases and the supernatant transmittance decreases, reflecting an increase in the stability of the juice cloud. 
At $\mathrm{pH} 6$, the effect of $\mathrm{HPH}$ treatment is more pronounced following the same trend as at $\mathrm{pH} 5.5$ when the pressure is $100 \mathrm{MPa}$ but decreasing the percentage of pulp and increasing the transmittance when the pressure is 150 MPa. Moreover, in this case, the changes can be associated with an increase in the stability of the juice cloud. The particles remaining in suspension may be small enough to allow more light to pass through, thus confirming the increase in transmittance.

One of the main applications of high homogenization pressures in fruit juices is to achieve pulp stabilization so that the pulp remains in suspension instead of settling [38]. In a study by Betoret et al. [25] analyzing transmittance in mandarin orange juices, it was observed that the turbidity of the juices increased when higher homogenization pressures were applied. Welti-Chanes et al. [39] observed the same effect in orange juice. In other cases, because of chemical changes and the increased contact surface between smaller particles generated by the application of high homogenization pressures, they may aggregate and precipitate more easily, decreasing the stability of the juice cloud $[37,40]$. The decrease in the percentage of pulp observed at a pressure of $150 \mathrm{MPa}$ in the lulo juice makes it possible to rule out this phenomenon.

It is widely referenced in scientific literature that during $\mathrm{HPH}$ treatment in fruit juices, shear stress causes the disruption of suspended particles and a reduction of particle size. Moreover, different works have described an asymptotic behavior; higher pressures cause less and less changes in particle diameter $[37,41]$. Thus, it indicates that disruption occurs preferentially in larger particles and cell clusters, with the small particles and cell fragments less susceptible to subsequent disruptions. This effect has been verified in lulo juice after evaluating the particle size distribution by using light scattering technique (Table 2 ).

$\mathrm{pH}, \mathrm{HPH}$ treatment, and fermentation had a significant effect on all parameters related to particle size. However, the most important changes were due to the HPH treatment; all parameters decreased as HPH pressure increased. $\mathrm{pH}$ and fermentation had a much weaker effect, slightly decreasing particle size. 
Table 2. Main parameters of particle size, before and after fermentation, of lulo juices at pH 5.5 and 6 , non-homogenized and homogenized at $100 \mathrm{MPa}$ and $150 \mathrm{MPa}$. D[4,3]: volume-weighed mean diameter; $\mathrm{D}[3,2]$ : surface based mean diameter; $\mathrm{d} 10, \mathrm{~d} 50$, and $\mathrm{d} 90$ : characteristic diameters below which $10 \%$, $50 \%$, and $90 \%$ of the particles are included in the distribution. Mean values \pm standard deviation.

\begin{tabular}{|c|c|c|c|c|c|c|c|}
\hline & & & $D[4,3]$ & $D[3,2]$ & $d_{10}$ & $d_{50}$ & $d_{90}$ \\
\hline \multirow{9}{*}{ 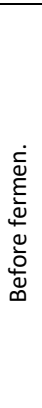 } & \multirow{3}{*}{$\mathrm{N}-\mathrm{HPH}$} & $\mathrm{pH} 5.5$ & $234 \pm 10^{\mathrm{h}}$ & $76.5 \pm 1.3^{\mathrm{fg}}$ & $62.71 \pm 0.95^{\mathrm{a}}$ & $176 \pm 3^{g}$ & $465 \pm 27^{g}$ \\
\hline & & & & & & & \\
\hline & & pH 6 & $220 \pm 8^{g}$ & $76.3 \pm 1.2^{\mathrm{cd}}$ & $64.1 \pm 0.9^{a}$ & $169 \pm 2^{f}$ & $420 \pm 28 \mathrm{~h}$ \\
\hline & \multirow{3}{*}{$100 \mathrm{MPa}$} & pH 5.5 & $83 \pm 2^{\mathrm{de}}$ & $31.4 \pm 1.2^{\mathrm{cd}}$ & $14.4 \pm 0.8^{b}$ & $69 \pm 2^{d}$ & $172 \pm 3^{e}$ \\
\hline & & & & & & & \\
\hline & & $\mathrm{pH} 6$ & $80.1 \pm 0.9^{c d}$ & $29.58 \pm 0.12^{\mathrm{ef}}$ & $13.8 \pm 0.2^{c}$ & $65.1 \pm 1.1^{\mathrm{c}}$ & $170 \pm 2^{\text {de }}$ \\
\hline & \multirow{3}{*}{$150 \mathrm{MPa}$} & $\mathrm{pH} 5.5$ & $69.7 \pm 1.2^{b}$ & $27.6 \pm 0.5^{b c}$ & $12.0 \pm 0.3^{d}$ & $59.0 \pm 0.8^{b}$ & $144 \pm 2^{c}$ \\
\hline & & & & & & & \\
\hline & & $\mathrm{pH} 6$ & $56.8 \pm 1.2^{\mathrm{a}}$ & $20.8 \pm 0.2^{h}$ & $8.86 \pm 0.14^{g}$ & $41.4 \pm 0.5^{a}$ & $128 \pm 3^{a}$ \\
\hline \multirow{8}{*}{ 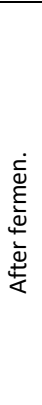 } & \multirow{3}{*}{$\mathrm{N}-\mathrm{HPH}$} & $\mathrm{pH} 5.5$ & $220 \pm 6^{h}$ & $73.4 \pm 0.9^{\mathrm{de}}$ & $61.7 \pm 0.6^{\mathrm{a}}$ & $177 \pm 2^{g}$ & $460 \pm 13^{f}$ \\
\hline & & & & & & & \\
\hline & & $\mathrm{pH} 6$ & $214 \pm 7^{f}$ & $72.7 \pm 0.8^{b}$ & $61.2 \pm 0.7^{\mathrm{a}}$ & $170 \pm 2^{f}$ & $412 \pm 15^{f}$ \\
\hline & \multirow{2}{*}{$100 \mathrm{MPa}$} & pH 5.5 & $88 \pm 2^{\mathrm{e}}$ & $30.3 \pm 1.2^{\mathrm{cd}}$ & $13.2 \pm 0.7^{c}$ & $73 \pm 2^{\mathrm{de}}$ & $184 \pm 3^{d}$ \\
\hline & & pH 6 & $74.8 \pm 1.3^{b c}$ & $25.5 \pm 0.3^{g}$ & $11.9 \pm 0.2^{f}$ & $59.7 \pm 0.8^{b}$ & $160 \pm 3^{c}$ \\
\hline & \multirow{3}{*}{$150 \mathrm{MPa}$} & pH 5.5 & $75.4 \pm 1.3^{b c}$ & $26.4 \pm 0.5^{f g}$ & $10.96 \pm 0.20^{\mathrm{e}}$ & $62.0 \pm 1.2^{\mathrm{b}}$ & $160 \pm 3^{b}$ \\
\hline & & & & & & & \\
\hline & & $\mathrm{pH} 6$ & $72 \pm 2^{\mathrm{b}}$ & $25.5 \pm 0.9^{a}$ & $13.2 \pm 0.5^{f}$ & $63 \pm 2^{b}$ & $144 \pm 4^{d}$ \\
\hline
\end{tabular}

Values with different superscript letters in a column are significantly different $(p \leq 0.05)$.

The data shown in Table 2 correspond in all cases to monomodal distribution curves with a single peak and a similar narrow distribution. The maximum corresponds to a diameter of about $210 \mu \mathrm{m}, 105 \mu \mathrm{m}$, and $93 \mu \mathrm{m}$ for the samples non-homogenized and those homogenized at 100 and $150 \mathrm{Mpa}$, respectively. These values decreased to about $200 \mu \mathrm{m}, 100 \mu \mathrm{m}$, and $90 \mu \mathrm{m}$ after fermentation with Lactobacillus reuteri. Although other authors [37,41] observed narrower distributions with increasing homogenization pressure, this effect was not observed for lulo juice. It is probable that the filtration step in the processing provided a more homogeneous juice as compared to non-filtered fruit juices.

Table 3 shows the results of the CIE-L*a*b* coordinates and the psychrometric $\mathrm{h}^{*}{ }_{\mathrm{ab}}$ and $\mathrm{C}^{*}{ }_{\mathrm{ab}}$ coordinates of the lulo juices before and after fermentation and as a function of homogenization pressure applied and $\mathrm{pH}$. To better explain the effect of $\mathrm{pH}, \mathrm{HPH}$ treatment, and fermentation with Lactobacillus reuteri, 
color coordinates for fresh lulo juice published by Hinestroza-Córdoba et al. [17] have been added to the Table 3 .

Table 3. CIE-L*a*b*, $\mathrm{h}^{*}{ }_{\mathrm{ab}}$ and $\mathrm{C}^{*}{ }_{\mathrm{ab}}$ coordinates of the lulo juices before and after fermentation and as a function of homogenization pressure applied and $\mathrm{pH}$. Mean values \pm standard deviation

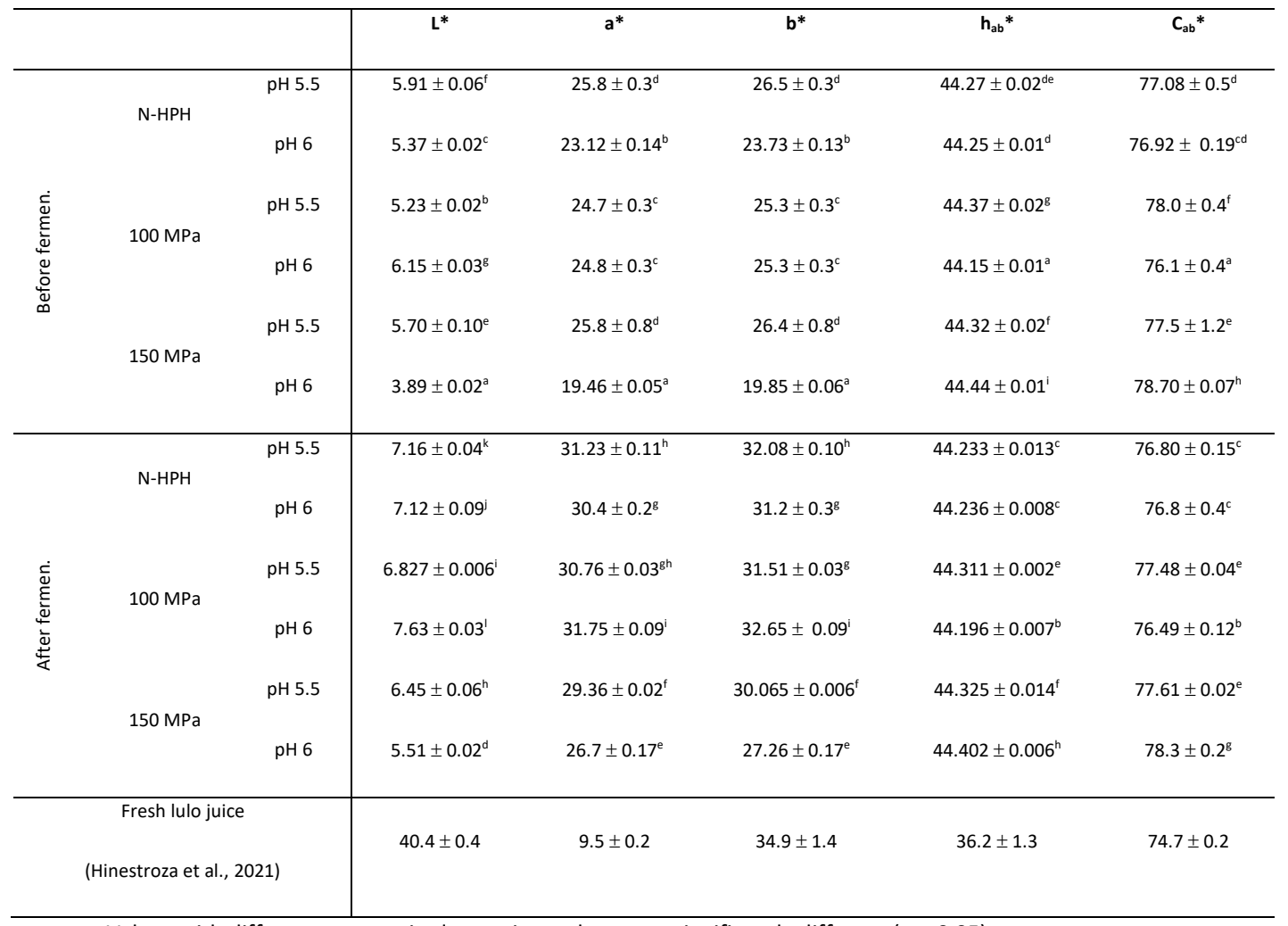

Values with different superscript letters in a column are significantly different $(p \leq 0.05)$.

A multifactorial analysis of variance shows a significant effect of $\mathrm{pH}$, $\mathrm{HPH}$, and fermentation on color coordinates, with fermentation being the variable with the largest significant effect.

To understand these effects, the structural characteristics of the fruit juices and the effect of the treatments on them should be considered. Fruit juices are colloidal suspensions integrated by the insoluble pulp dispersed in a viscous solution. Pulp is constituted of cell fragments including insoluble polymers and molecules. The viscous solution is an aqueous solution of soluble polysaccharides, sugars, salts, and acids. The interactions within each phase and between them will determine physical properties such as the color. Since 
$\mathrm{pH}, \mathrm{HPH}$, and fermentation affect both aqueous and pulp phases, they also influence the color.

It can be observed that the brightness of the juices drops when sodium bicarbonate is added to adjust the $\mathrm{pH}$ and $\mathrm{HPH}$ treatment is applied (5.91 \pm 0.06 in $\mathrm{N}-\mathrm{HPH}$ juice vs. $3.89 \pm 0.02$ in $150 \mathrm{MPa}$ treated juice). This effect is associated with an increase in suspended particles and with an increased cloud stability. In addition, after fermentation and regardless of $\mathrm{HPH}$ treatment, the color coordinate $a^{*}$ undergoes a noticeable increase in color intensity towards red (31.23 $\pm 0.11>25.8 \pm 0.3 \mathrm{in} \mathrm{N-HPH}$ juice), and the color coordinate $b^{*}$ also shows a slight increase reflecting a gain of yellow color intensity $(32.08 \pm 0.10>26.5 \pm 0.3)$. In relation to the value of $h^{*}{ }_{a b}$, it can be observed that it is higher than that of the fresh lulo juice, which is consistent with the redder shades reflected by the coordinate a*. Finally, the psychrometric coordinate that refers to the chromaticity $\left(C^{*}{ }_{a b}\right)$, which measures the purity and saturation of color, underwent slight changes with the $\mathrm{pH}$ adjustment, the $\mathrm{HPH}$ treatment, or the fermentation step.

Figure 3 shows total phenols content, flavonoids content, and antiradical capacity measured by DPPH and ABTS methods of the lulo juices before and after fermentation and as a function of the homogenization pressure applied and the $\mathrm{pH}$.
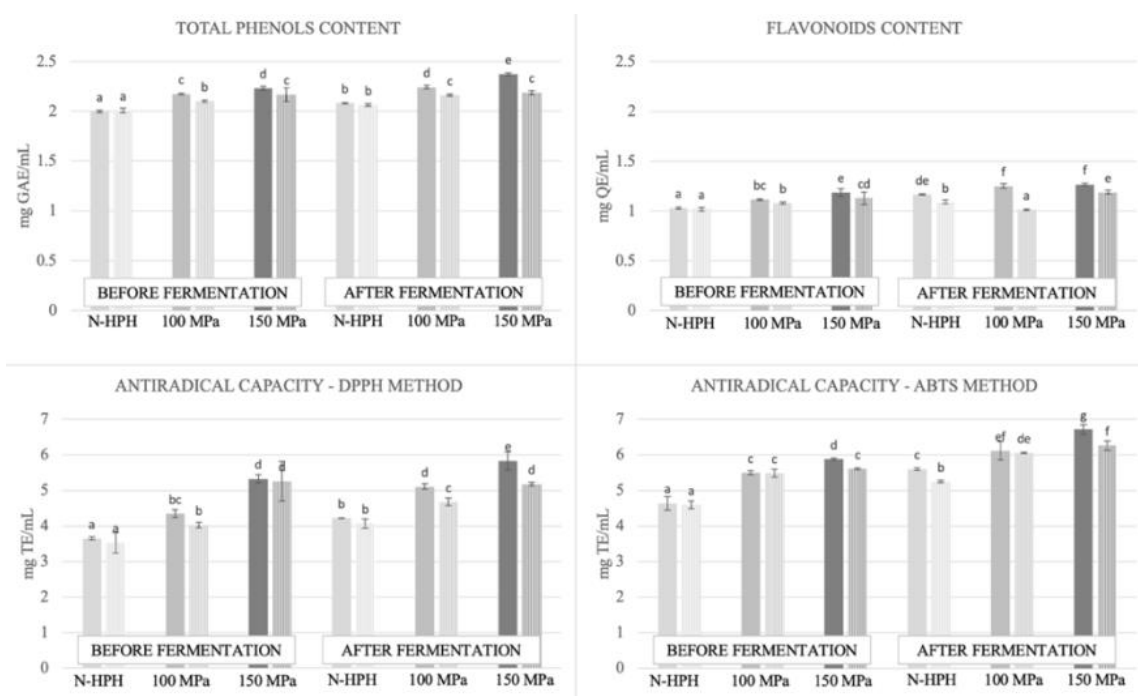

Figure 3. Total phenols content, flavonoids content, and antiradical capacity by DPPH and ABTS methods of the lulo juices before and after fermentation and as a function of homogenization pressure applied and $\mathrm{pH}$. Solid bars represent juices at $\mathrm{pH} 5.5$ and the striped bars represent juices at $\mathrm{pH}$ 6. Different letters denote statistically significant differences $(p \leq 0.05)$. 
The content of total phenols and flavonoids in both fermented and non-fermented lulo juice increased as it did the homogenization pressure. In addition, juices at pH 5.5 (solid bars) showed slightly higher contents of these two types of compounds compared to those at $\mathrm{pH} 6$ (striped bars). The effect of the two factors was statistically significant $(p \leq 0.05)$.

The mechanical effect of homogenization pressure on suspended particles results, in many cases, in the breakdown of cell structure and the subsequent release of chemical compounds, including phenols and flavonoids, into the aqueous phase making them more accessible to react with radicals [35]. Furthermore, a restriction of enzymatic degradation of phenolic compounds as a consequence of the HPH effect on enzymatic activity may have occurred. Velázquez-Estrada et al. [42] found the same effect on phenols and flavonoids in orange juice.

The results for the antiradical capacity (DPPH and ABTS methods) followed a similar trend as for phenols and flavonoids. The ABTS and DPPH methods determine the antiradical capacity of compounds with different hydrophilic nature: the ABTS radical reacts with compounds of a more hydrophilic nature than the DPPH radical. However, the great diversity of components of different nature with antiradical capacity existing in the juice of lulo resulted in high values in both cases. Moreover, Hinestroza-Córdoba et al. [17] determined the profile of phenolic compounds by liquid chromatography coupled with mass spectroscopy and showed a considerable increase in the diversity of phenolic compounds when applying a homogenization treatment to lulo juice. Considering that the antioxidant capacity of a mixture is not only given by the sum of the antioxidant capacities of each of its components, since the compounds interact with each other and can produce synergistic or inhibitory effects, it would be possible that the increase in the diversity of phenolic compounds is associated, in lulo juice, with an increase in the antiradical capacity of the juices when applying the $\mathrm{HPH}$ treatment.

After juice samples fermentation, a significant improvement in the antioxidant properties of the juices was observed. Both total phenol and flavonoid contents increased after the fermentative action of Lactobacillus reuteri. Similar results were obtained by Balli et al. [43], who found that Lactobacillus increased the content of total phenols in cereals by $30 \%$. The 
results were attributed to the release of phenols that were physically or chemically trapped in the soluble and fermentable fiber of the feed.

The antiradical capacity determined by both DPPH and ABTS methods also experienced a significant increase after fermentation, being more evident for the results obtained by ABTS. This increase was positive with the homogenization pressure applied and more pronounced at $\mathrm{pH} 5.5$ than at $\mathrm{pH}$ 6 . In addition to the release of components with antiradical activity and the generation of secondary metabolites in the fermentation process, the microbial cells themselves may have contributed to the increased antiradical capacity. Although there are no studies demonstrating this activity for Lactobacillus reuteri, there is strong evidence of the antioxidant activity of Lactobacillus plantarum, Lactobacillus helveticus, Lactobacillus acidophilus, Lactobacillus fermentum, Lactobacillus casei, and some bifidobacteria strains [44].

3.2. Effect of Gastrointestinal Digestion on the Viable Cell Content in Lulo Juices at Different $\mathrm{pH}$ and Homogenization Pressures

Figure 4 includes viable cell counts and survival rate (Rs) (calculated as explained in Section 2.5) of Lactobacillus reuteri along gastric and intestinal stages of the in vitro simulated gastrointestinal digestion process for all the fermented lulo juices. Analysis of variance $(p \leq 0.05)$ showed that both the initial $\mathrm{pH}$ and the homogenization pressure had a significant effect on the survival of Lactobacillus reuteri to the in vitro simulated gastrointestinal digestion process. Furthermore, there was a significant interaction between the two factors.

In all cases, the increase in acidity and the presence of pepsin associated with the beginning of the gastric stage caused a decrease in the number of viable cells of up to 1.5 log units. However, at the end of this stage, the viable cell content remained almost constant in the juices subjected to the $\mathrm{HPH}$ treatment, and slightly decreased in the case of non-homogenized ones. Similarly, the onset of the intestinal phase caused a pronounced decrease in viable cell content, with less changes $2 \mathrm{~h}$ later. This evolution in the viable count during the simulation of the gastrointestinal process is similar to that reported by García-Hernández et al. [45] for Lactobacillus reuteri ATCC 55730 in raw and fried tomato puree. As for the enhancement in the microbial strain survival to simulated gastric conditions in HPH juices, reference should be 
made to their higher content in both total phenols and flavonoids content and to the polyphenols ability to enhance microorganisms' survivability to gastric conditions by protecting them from oxygen toxicity $[45,46]$.

Microbial cells growth in juices at pH 5.5 showed lower tolerance to the drastic conditions of gastric stage than that growth in juices adjusted to $\mathrm{pH}$ 6. However, the microbial cell in juices at $\mathrm{pH} 5.5$ showed better survival rate after $2 \mathrm{~h}$ in this stage specially when the HPH treatment was applied. The survival rate in intestinal stage was different being higher for microbial cell in juices at $\mathrm{pH} 5.5$ both at the beginning and at the end of the stage. Only, the non-homogenized juices at $\mathrm{pH} 6$ show a different behavior between the initial and final time of intestinal stage. In relation to the HPH treatment, the highest survival was achieved by cells incubated in juices treated at $150 \mathrm{MPa}$.

Overall, the best resistance to simulated gastrointestinal digestion was observed in the juice at $\mathrm{pH} 5.5$ and homogenized at $150 \mathrm{MPa}$ with $82 \%$ of survival (calculated as the ratio between the microbial concentration at the end of the intestinal stage and the microbial concentration before in vitro digestion, both referred to the same basis), although in the other juices it was only $5 \%$ lower, reaching values of $80-81 \%$. In all cases, levels above $7 \log _{10}$ units per $\mathrm{mL}$ of juice were reached at the end of the intestinal stage; these are levels above the minimum necessary for a food to exert a probiotic effect [47]. Islam et al. [48] found a survivability of $84-85 \%$ of Lactobacillus acidophilus LA-5 in a whey-pineapple beverage (25\% whey) at $\mathrm{pH} 4.3$ after simulated gastrointestinal digestion. Moreover, this survival only decreased by $5 \%$ after more than 50 days of refrigerated storage. However, in this work, the survival was much higher than that achieved by Calabuig-Jiménez et al. [49] in mandarin juice at $\mathrm{pH} 3.7$ with Lactobacillus salivarius subsp.salivarius, which was only $60 \%$.

Among the factors that affect the probiotic bacteria viability in a fruit juice after the gastrointestinal digestion process are the microbial strain and its resistance to acidic conditions and gastric fluids, the fruit juice composition (acidity, carbohydrate content, nitrogen sources, mineral content), and the possible interactions of the probiotic strains with the food matrix component [45]. In this case, it would be both, adaptation of strain to juice acidity and the good nutrient composition of the lulo juice, the main factors responsible for the favorable survival levels obtained after in vitro gastrointestinal digestion. Moreover, the homogenization treatment at $150 \mathrm{MPa}$ would have contributed 
to the availability of nutrients due to the smaller size of the suspended particles and the greater stability of the cloud.
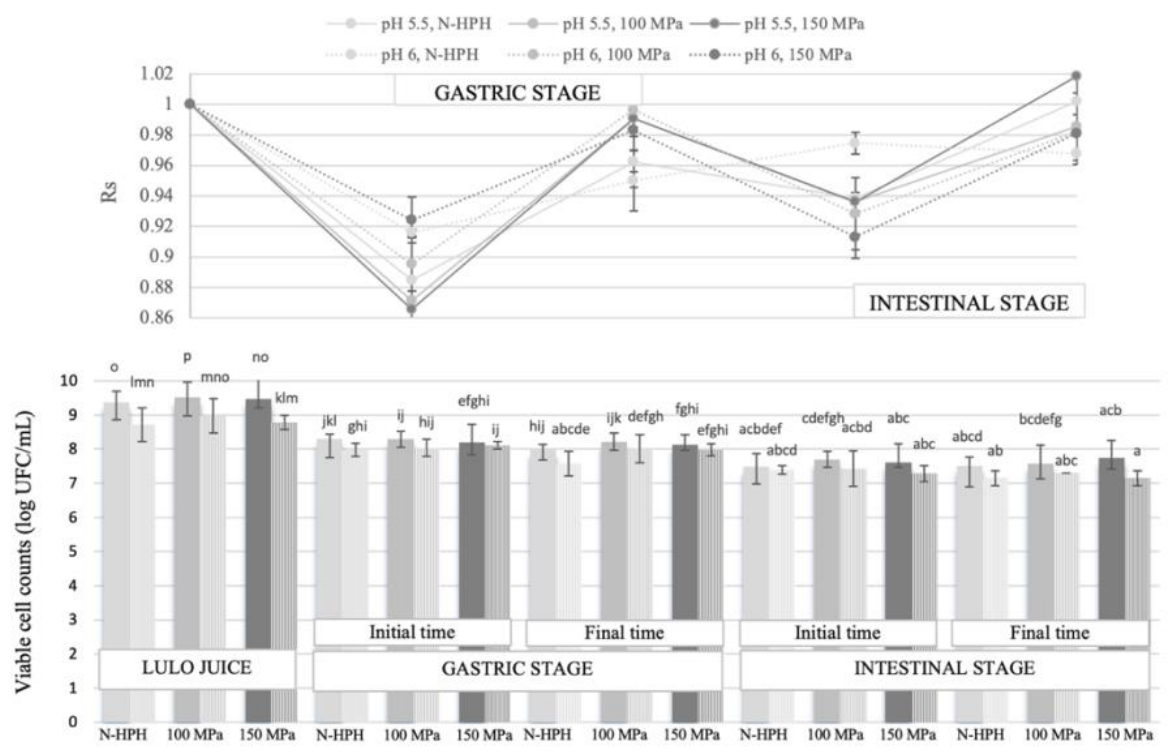

Figure 4. Viable cell counts and survival rate (Rs) of Lactobacillus reuteri along gastric and intestinal stages of the simulated gastrointestinal digestion process in vitro. Fermented lulo juices at $\mathrm{pH} 5.5$ and 6, non-homogenized (N-HPH) and homogenized at $100 \mathrm{MPa}(100 \mathrm{MPa})$ and $150 \mathrm{MPa}(150 \mathrm{MPa}$ ) has been included. The solid bars refer to juices with $\mathrm{pH} 5.5$ and the striped bars refer to juices with $\mathrm{pH}$ 6. Different letters denote significant differences $(p \leq 0.05)$.

\section{Conclusions}

$\mathrm{HPH}$ treatment in lulo juice affected, mainly, suspended particles size, with a smaller effect when increasing the pressure from 100 to $150 \mathrm{MPa}$. This effect on particle size resulted in a juice with greater pulp stability and a different color characterized by a loss of brightness and an increase in color intensity towards red. The HPH treatment also favored the release of components of an antiradical nature, affecting them in a similar way regardless of their hydrophilic or hydrophobic nature.

Regarding the growth of Lactobacillus reuteri, it was mainly affected by the $\mathrm{pH}$ of the medium, being the rectified juice at $\mathrm{pH} 5.5$ the most appropriated one.

The growth of Lactobacillus reuteri slightly modified the physicochemical properties of both non-homogenized and homogenized 
juices, following the same trend, but mainly increased the antiradical capacity of the juices, possibly due to the release of components with this capacity that were trapped in the soluble and fermentable fiber fraction.

In general, Lactobacillus reuteri showed good resistance to in vitro gastrointestinal digestion conditions, reaching levels above $10^{7} \mathrm{CFU} / \mathrm{mL}$ in all cases. The highest resistance was observed in the juice treated at $150 \mathrm{MPa}$ followed by the juice homogenized at $100 \mathrm{MPa}$.

Overall, fermentation of lulo juice with Lactobacillus reuteri at pH 5.5 and after an $\mathrm{HPH}$ treatment of $150 \mathrm{MPa}$ improves the antioxidant properties of the juice and is favorable for providing the bacterial cells in adequate quantities to exert their potential probiotic effect after gastrointestinal digestion. The results could be used to develop beverages with tropical flavors and potential antioxidant and probiotic properties. In vivo studies would be necessary to assess organoleptic acceptability and health effects.

Author Contributions: Conceptualization, supervision, project administration, funding acquisition and review, N.B., E.B.; data curation, L.I.H.-C.; writing-original draft preparation, N.B. and L.I.H.-C.; writing-review and editing, L.S. and C.B. All authors have read and agreed to the published version of the manuscript.

Acknowledgments: Authors thank the grant provided to Leidy I. Hinestroza by Technological University of Chocó-Colombia [Fortalecimiento de los Encadenamientos Productivos de las Subregiones del Chocó. BPIN 2013000100284].

\section{References}

1. Butnariu, M.; Sarac, I. Functional food. Int.J. Nutr. 2019, 3, 7-16.

2. Hill, C.; Guarner, F.; Reid, G.; Gibson, G.R.; Merenstein, D.J.; Pot, B.; Morelli, L.; Canani, R.B.; Flint, H.J.; Salminen, S.; et al. The international scientific association for probiotics and prebiotics consensus statement on the scope and appropriate use of the term probiotic. Nat. Rev. Gastroenterol. Hepatol. 2014, 11, 506-514.

3. De Bellis, P.; Sisto, A.; Lavermicocca, P. Probiotic bacteria and plant-based matrices: An association with improved health-promoting features. J. Funct. Foods 2021, 87, 104821.

4. Messinger, J.; Lauerer, M. Solanum quitoense, a new greenhouse crop for Central Europe: Flowering and fruiting respond to photoperiod. Sci. Hortic. 2015, 183, 23-30.

5. Forero, D.P.; Masatani, C.; Fujimoto, Y.; Coy-Barrera, E.; Peterson, D.G.; Osorio, C. Spermidine derivatives in lulo (Solanum quitoense Lam.) fruit: Sensory (Taste) versus biofunctional (ACE-inhibition) properties. J. Agric. Food Chem. 2016, 64, 5375-5383.

6. Dahiya, D.K.; Renuka; Puniya, M.; Shandilya, U.K.; Dhewa, T.; Kumar, N.; Kumar, S.; Puniya, A.K.; Shukla, P. Gut microbiota modulation and its relationship with obesity using prebiotic fibers and probiotics: A review. Front. Microbiol. 2017, 8, 563.

7. Chakkaravarthi, S.; Aravind, S.M. Fruit juice added with prebiotics and probiotics. Probiotics Prebiotics Foods 2021, 62, 219-232. 
8. Stevens, M.; Vollenweider, S.; Lacroix, C.; Zurich, E.T.H. The potential of reuterin produced by Lactobacillus reuteri as a broad spectrum preservative in food. Prot. Cult. Antimicrob. Metab. Bacteriophages Food Beverage Biopreserv. 2011, 129-160.

9. Casas, I.A.; Dobrogosz, W.J. Validation of the probiotic concept: Lactobacillus reuteri confers broad-spectrum protection against disease in humans and animals. 2009, 12, 247-285.

10. Francavilla, R.; Lionetti, E.; Castellaneta, S.P.; Magistà, A.M.; Maurogiovanni, G.; Bucci, N.; De Canio, A.; Indrio, F.; Cavallo, L.; lerardi, E.; et al. Inhibition of Helicobacter pylori infection in humans by Lactobacillus reuteri ATCC 55730 and effect on eradication therapy: A pilot study. Helicobacter 2008, 13, 127-134.

11. Petricevic, L.; Unger, F.M.; Viernstein, H.; Kiss, H. Randomized, double-blind, placebocontrolled study of oral lactobacilli to improve the vaginal flora of postmenopausal women. Eur. J. Obstet. Gynecol. Reprod. Biol. 2008, 141, 54-57.

12. Anukam, K.C.; Osazuwa, E.; Osemene, G.I.; Ehigiagbe, F.; Bruce, A.W.; Reid, G. Clinical study comparing probiotic Lactobacillus GR-1 and RC-14 with metronidazole vaginal gel to treat symptomatic bacterial vaginosis. Microbes Infect. 2006, 8, 2772-2776.

13. Tenorio-Jiménez, C.; Martínez-Ramírez, M.J.; Tercero-Lozano, M.; Arraiza-Irigoyen, C.; Del Castillo-Codes, I.; Olza, J.; Plaza-Díaz, J.; Fontana, L.; Migueles, J.H.; Olivares, M.; et al. Evaluation of the effect of Lactobacillus reuteri V3401 on biomarkers of inflammation, cardiovascular risk and liver steatosis in obese adults with metabolic syndrome: A randomized clinical trial (PROSIR). BMC Complement. Altern. Med. 2018, 18, 306.

14. Santos, F.; Wegkamp, A.; De Vos, W.M.; Smid, E.J.; Hugenholtz, J. High-level folate production in fermented foods by the B12 producer Lactobacillus reuteri JCM1112. Appl. Environ. Microbiol. 2008, 74, 3291-3294.

15. Perricone, M.; Corbo, M.R.; Sinigaglia, M.; Speranza, B.; Bevilacqua, A. Viability of Lactobacillus reuteri in fruit juices. J. Funct. Foods 2014, 10, 421-426.

16. Kubo, M.T.K.; Tribst, A.A.L.; Augusto, P.E.D. High Pressure Homogenization in Fruit and Vegetable Juice and Puree Processing: Effects on Quality, Stability and Phytochemical Profile; Elsevier: Amsterdam, The Netherlands, 2021; Volume 3, ISBN 9780081005965.

17. Hinestroza-Córdoba, L.I.; Barrera, C.; Seguí, L.; Betoret, N. Potential use of vacuum impregnation and high-pressure homogenization to obtain functional products from lulo fruit (Solanum quitoense Lam.). Foods 2021, 10, 817.

18. Patrignani, F.; Lanciotti, R. Applications of high and ultra high pressure homogenization for food safety. Front. Microbiol. 2016, 7, 1132.

19. Betoret, E.; Calabuig-Jiménez, L.; Patrignani, F.; Lanciotti, R.; Dalla Rosa, M. Effect of high pressure processing and trehalose addition on functional properties of mandarin juice enriched with probiotic microorganisms. LWT 2017, 85, 418-422.

20. Muramalla, T.; Aryana, K.J. Some low homogenization pressures improve certain probiotic characteristics of yogurt culture bacteria and Lactobacillus acidophilus LA-K1. J. Dairy Sci. 2011, 94, 3725-3738.

21. Tabanelli, G.; Patrignani, F.; Vinderola, G.; Reinheimer, J.A.; Gardini, F.; Lanciotti, R. Effect of sub-lethal high pressure homogenization treatments on the in vitro functional and biological properties of lactic acid bacteria. LWT 2013, 53, 580-586.

22. Minekus, M.; Alminger, M.; Alvito, P.; Ballance, S.; Bohn, T.; Bourlieu, C.; Carrière, F.; Boutrou, R.; Corredig, M.; Dupont, D.; et al. A standardised static in vitro digestion method suitable for food-an international consensus. Food Funct. 2014, 5, 1113-1124.

23. ISO 2173:2003. Fruit and Vegetable Products-Determination of Soluble SolidsRefractometric Method; International Organisation for Standardization: Geneva, Switzerland.

24. ISO 758:1976. Liquid Chemical Products for Industrial Use-Determination of Density at $20^{\circ} \mathrm{C}$; International Organisation for Standardization: Geneva, Switzerland.

25. Betoret, E.; Betoret, N.; Carbonell, J.V.; Fito, P. Effects of pressure homogenization on particle size and the functional properties of citrus juices. J. Food Eng. 2009, 92, 18-23.

26. Malvern Instruments. Manual: Sample Dispersion \& Refractive Index Guide (Mastersizer 2000) Reference Manual; Malvern Instruments Ltd.: Malvern, UK, 2000. 
27. CIE. Colorimetry, 2nd ed.; Technical Report CIE 15.2; Commission Internationale de L'Eclairage: Paris, France, 1986.

28. Singleton, V.L.; Orthofer, R.; Lamuela-Raventós, R.M. Analysis of total phenols and other oxidation substrates and antioxidants by means of folin-ciocalteu reagent. Methods Enzymol. 1999, 299, 152-178.

29. Wolfe, K.L.; Liu, R.H. Apple peels as a value-added food ingredient. J. Agric. Food Chem. 2003, 51, 1676-1683.

30. Luximon-Ramma, A.; Bahorun, T.; Soobrattee, M.A.; Aruoma, O.I. Antioxidant activities of phenolic, proanthocyanidin, and flavonoid components in extracts of Cassia fistula. J. Agric. Food Chem. 2002, 50, 5042-5047.

31. Kuskoski, E.M.; Asuero, A.G.; Troncoso, A.M.; Mancini-Filho, J.; Fett, R. Aplicación de diversos métodos químicos para determinar actividad antioxidante en pulpa de frutos. Ciência Tecnol. Aliment. 2005, 25, 726-732.

32. Stratil, P.; Klejdus, B.; Kubáň, V. Determination of total content of phenolic compounds and their antioxidant activity in vegetables-Evaluation of spectrophotometric methods. J. Agric. Food Chem. 2006, 54, 607-616.

33. Re, R.; Pellegrini, N.; Proteggente, A.; Pannala, A.; Yang, M.; Rice-Evans, C. Antioxidant activity applying an improved ABTS radical cation decolorization assay. Free Radic. Biol. Med. 1999, 26, 1231-1237.

34. Messer, J.W.; Johnson, C.H. Total viable counts. Pour plate technique. Encycl. Food Microbiol. 2000, 3, 2154-2158.

35. Zhou, L.; Guan, Y.; Bi, J.; Liu, X.; Yi, J.; Chen, Q.; Wu, X.; Zhou, M. Change of the rheological properties of mango juice by high pressure homogenization. LWT 2017, 82, 121-130.

36. Kubo, M.T.K.; Augusto, P.E.D.; Cristianini, M. Effect of high pressure homogenization (HPH) on the physical stability of tomato juice. Food Res. Int. 2013, 51, 170-179.

37. Lacroix, N.; Fliss, I.; Makhlouf, J. Inactivation of pectin methylesterase and stabilization of opalescence in orange juice by dynamic high pressure. Food Res. Int. 2005, 38, 569-576.

38. Quan, W.; Tao, Y.; Qie, X.; Zeng, M.; Qin, F.; Chen, J.; He, Z. Effects of high-pressure homogenization, thermal processing, and milk matrix on the in vitro bioaccessibility of phenolic compounds in pomelo and kiwi juices. J. Funct. Foods 2020, 64, 103633.

39. Welti-Chanes, J.; Ochoa-Velasco, C.E.; Guerrero-Beltrán, J.Á. High-pressure homogenization of orange juice to inactivate pectinmethylesterase. Innov. Food Sci. Emerg. Technol. 2009, 10, 457-462.

40. Augusto, P.E.D.; Ibarz, A.; Cristianini, M. Effect of high pressure homogenization (HPH) on the rheological properties of tomato juice: Time-dependent and steady-state shear. J. Food Eng. 2012, 111, 570-579.

41. Silva, V.M.; Sato, A.C.K.; Barbosa, G.; Dacanal, G.; Ciro-Velásquez, H.J.; Cunha, R.L. The effect of homogenisation on the stability of pineapple pulp. Int. J. Food Sci. Technol. 2010, 45, 2127-2133.

42. Velázquez-Estrada, R.M.; Hernández-Herrero, M.M.; Rüfer, C.E.; Guamis-López, B.; RoigSagués, A.X. Influence of ultra high pressure homogenization processing on bioactive compounds and antioxidant activity of orange juice. Innov. Food Sci. Emerg. Technol. 2013, 18, 89-94.

43. Balli, D.; Bellumori, M.; Pucci, L.; Gabriele, M.; Longo, V.; Paoli, P.; Melani, F.; Mulinacci, N.; Innocenti, M. Does fermentation really increase the phenolic content in cereals? A study on millet. Foods 2020, 9, 303.

44. Fernandes Pereira, A.L.; Rodrigues, S. Turning fruit juice into probiotic beverages. Fruit Juices 2018, 279-287, doi:10.1016/B978-0-12-802230-6.00015-1.

45. García-Hernández, J.; Hernández-Pérez, M.; Peinado, I.; Andrés, A.; Heredia, A. Tomatoantioxidants enhance viability of $L$. reuteri under gastrointestinal conditions while the probiotic negatively affects bioaccessibility of lycopene and phenols. J. Funct. Foods 2018, 43, 1-7.

46. Kemsawasd, V.; Chaikham, P.; Rattanasena, P. Survival of immobilized probiotics in chocolate during storage and with an in vitro gastrointestinal model. Food Biosci. 2016, 16, 37-43. 
47. Koirala, S.; Anal, A.K. Probiotics-based foods and beverages as future foods and their overall safety and regulatory claims. Futur. Foods 2021, 3, 100013.

48. Islam, M.Z.; Tabassum, S.; Harun-ur-Rashid, M.; Vegarud, G.E.; Alam, M.S.; Islam, M.A. In vitro bioaccessibility of isoflavones from a soymilk-based beverage as affected by thermal and non-thermal processing MaríaDevelopment of probiotic beverage using whey and pineapple (Ananas comosus) juice: Sensory and physico-chemical properties and pr. J. Agric. Food Res. 2021, 4, 100144.

49. Calabuig-Jiménez, L.; Betoret, E.; Betoret, N.; Patrignani, F.; Barrera, C.; Seguí, L.; Lanciotti, R.; Dalla Rosa, M. High pressures homogenization (HPH) to microencapsulate L. salivarius spp. salivarius in mandarin juice. Probiotic survival and in vitro digestion. J. Food Eng. 2019, 240, 43-48. 


\section{Conclusiones del capítulo 3.2}

El enorme aumento de la obesidad y, en consecuencia, de los trastornos fisiológicos asociados a ella, ha provocado un incremento masivo de los trabajos de investigación realizados en este ámbito en los últimos 10 años. La relación entre la dieta y la incidencia del síndrome metabólico esta claramente contrastada. Aunque esta relación es tremendamente compleja, numerosos trabajos específicos establecen los fitoquímicos y los probióticos como dos de los componentes activos presentes en los alimentos, que más efecto tienen en la prevención y en la reducción de los síntomas asociados al síndrome metabólico.

En la actualidad, el desarrollo tecnológico alcanzado por la industria alimentaria permite tanto el diseño y desarrollo de alimentos específicos que incluyen componentes activos en su composición como la aplicación de técnicas específicas que incrementan el valor funcional de los alimentos naturales. El uso de estos avances en la dirección correcta puede ser decisivo en la solución de los problemas de salud relacionados con la obesidad. En concreto, las aplicaciones de presiones de homogeneización moderadas o las técnicas de formulación de alimentos como la impregnación al vacío, se presentan como posibilidades para desarrollar alimentos líquidos y/o sólidos que combinen la presencia de fitoquímicos y probióticos contra la obesidad en alimentos naturales como el lulo.

En la última década, ha crecido en más de un $80 \%$ el número de trabajos de investigación relacionados con la aplicación de la HPH en el proceso de extracción de componentes bioactivos a partir de residuos agroalimentarios; en la mejora de la biodisponibilidad y las propiedades probióticas de los componentes bioactivos y los microorganismos; y también como técnica de encapsulación. Al mismo tiempo, se ha avanzado en la aplicación de la HPH para reducir la carga microbiana o modular la actividad de algunas enzimas. Concretamente, la aplicación de las HPH en zumos de frutas permite reducir el tratamiento térmico necesario para la conservación de los mismos, al mismo tiempo que mejora las propiedades físico-químicas y aumenta la disponibilidad de los componentes bioactivos con propiedades antioxidantes. Estos resultados la configuran como una técnica de gran interés 
para la obtención de zumos de frutas tropicales que conserven su aroma, incorporen una mayor cantidad de fibra y tengan un elevado valor nutricional.

El fruto del lulo (Solanum quitoense Lam), de gran importancia económica en la región del pacífico colombiano, ha resultado ser una fruta adecuada para la obtención de alimentos medianamente procesados ricos en polifenoles, poliaminas y otros componentes antioxidantes. Sus parámetros de impregnación permitirían la incorporación de protectores, conservantes, compuestos fisiológicamente activos u otros aditivos, permitiendo el desarrollo de alimentos sólidos de alto valor nutricional dirigidos a poblaciones con deficiencias especificas.

Por otra parte, aunque la obtención de zumo de lulo implicó la pérdida de algunos compuestos bioactivos debido a la retención de parte de los sólidos en la operación de filtrado, la homogeneización de este a presiones de 100$150 \mathrm{MPa}$ aumentó la capacidad antiradical hasta valores similares a los de la fruta fresca. Además, el tratamiento de HPH incrementó la diversidad de polifenoles y de aminas bioactivas como la N, N, N-tris(dihidrocafeoil) espermidina y la N, N-bis(dihidrocafeoil) espermidina, cuyo efecto contra la hipertensión se ha demostrado en estudios publicados por otros autores.

El zumo de lulo inoculado con Lactobacillus reuteri tratado con presiones moderadas ( 100 y $150 \mathrm{MPa}$ ) y a diferentes $\mathrm{pH}$ mejoró la viabilidad del microrganismo probiótico, y de las propiedades funcionales, con buena capacidad de resistencia a las condiciones desfavorable de la digestión in vitro. 
3.3. Fuentes alternativas de ingredientes de alto valor funcional a partir de subproductos de la industrialización de frutas 
Resultados y discusión 
La industria alimentaria es responsable del $40 \%$ de los residuos generados en toda la cadena alimentaria. En regiones con una alta producción de frutas, el procesado de estas para la obtención de zumo genera grandes cantidades de residuos con propiedades y composiciones muy diferentes. En función del procesado, el residuo de industrialización de algunas frutas puede llegar a representar más de la mitad del fruto, estando compuesto, principalmente, por la corteza, la pulpa y las semillas. Estos residuos, en muchos casos, contienen porcentajes elevados de los compuestos bioactivos responsables de los efectos beneficiosos sobre la salud de las frutas de las que provienen.

Los polvos de frutas se han convertido en una nueva forma de consumirlas. No en vano, la fabricación de polvos a partir de frutas y vegetales ha suscitado un creciente interés en los últimos años. Se trata de productos con propiedades beneficiosas para la salud que se presentan en forma concentrada y muy versátiles, con posibilidad de ser utilizados de forma sencilla y rápida como aditivo, aliño o en la formulación de alimentos. La fabricación de polvos a partir de los subproductos de industrialización de frutas podría emplearse con fines similares, con la ventaja de estar convirtiendo un material de desecho en un producto de alto valor añadido.

Para el caso de la obtención de zumo de lulo altamente nutritivo que se ha venido desarrollando en los capítulos anteriores, un desarrollo sostenible exige la valoración de la composición y propiedades del bagazo resultante y la propuesta de procedimientos que aseguren un aprovechamiento integral del mismo.

Bajo estas premisas se planteó determinar la composición y propiedades del bagazo resultante del proceso de obtención de zumo de lulo y estudiar el efecto de las condiciones del proceso de obtención de un polvo funcional (fundamentalmente de las operaciones de triturado y deshidratación) sobre las propiedades fisicoquímicas y funcionales del producto final. El producto resultante podría incorporarse como ingrediente a nivel industrial para el enriquecimiento de alimentos, o como ingrediente a nivel doméstico para paliar las deficiencias detectadas en la población infantil del departamento del Chocó o los problemas de obesidad e hipertensión de su población adulta. Concretamente, se estudió el efecto de la temperatura de secado por aire caliente $\left(60\right.$ y $\left.70^{\circ} \mathrm{C}\right)$ y la liofilización. También se consideró 
como variable la intensidad del triturado del bagazo deshidratado, obteniéndose un polvo de granulometría fina y otro de granulometría gruesa. Los polvos se caracterizaron en términos de humedad, tamaño de partícula, actividad de agua, propiedades antioxidantes y color, propiedades de interacción con el agua solubilidad, higroscopicidad, capacidad de hinchamiento, isotermas, capacidad retener y atrapar agua, propiedades emulsionantes y contenido en caroteniodes.

Los resultados del trabajo de investigación se publicaron en la revista Foods (ISSN: 2304-8158; Current Impact Factor: 4.350; 5-year Impact Factor: 4.957; JCR category rank: Q2: Food Science \& Technology).

Hinestroza-Córdoba, L.I.; Duarte Serna, S.; Seguí, L.; Barrera, C.; Betoret, N. Characterization of Powdered Lulo (Solanum quitoense) Bagasse as a Functional Food Ingredient. Foods 2020, 9, 723.https://doi.org/10.3390/foods9060723.

Los resultados obtenidos pusieron de manifiesto que el bagazo de lulo es una materia prima adecuada para obtener un polvo rico en fibra $y$ carotenoides, que podría ser utilizado como ingrediente en la industria alimentaria y también a nivel doméstico. Se mostró un desequilibrio en la proporción entre fibra soluble e insoluble, lo que debería tenerse en cuenta en las aplicaciones posteriores y sobre todo si el producto se utiliza para alimentación infantil.

La cinética del proceso de deshidratación mostró que, en la primera etapa del proceso de secado por aire caliente, el transporte molecular de agua desde las capas más internas hasta la superficie del lecho sólido no se vio afectado por la temperatura del aire. Las características estructurales y la composición del bagazo determinaron un control interno, pudiéndose reducir en esta etapa la temperatura del aire por debajo de los $70^{\circ} \mathrm{C}$ con el consiguiente ahorro de energía.

Las ligeras diferencias observadas en el contenido de agua de la monocapa proporcionadas por las isotermas para las diferentes condiciones de procesado, mostraron la alta estabilidad esperada de los polvos del bagazo de lulo. Aunque las diferencias en el parámetro $C$ del modelo de BET mostraron importantes cambios estructurales y físicos a lo largo del secado, las características fisicoquímicas como el color no se vieron muy afectadas. 
Tanto la granulometría como las condiciones de deshidratación influyeron en las propiedades del polvo final. Una granulometría más fina conduce, independientemente de las condiciones de deshidratación, a mejores propiedades de interacción con el agua y, especialmente, a una mayor solubilidad. En relación con los métodos de deshidratación, la liofilización es el método que proporciona mejores propiedades antioxidantes y un mayor contenido de carotenoides, aunque el contenido de carotenoides también es aceptable en el secado por aire caliente a $60{ }^{\circ} \mathrm{C}$. 


\title{
Characterization of Powdered lulo (Solanum quitoense) Bagasse as a Functional Food Ingredient
}

\author{
Leidy Indira Hinestroza-Córdoba ${ }^{1,2}$, Stevens Duarte Serna 2, Lucía Seguí ${ }^{2}$, \\ Cristina Barrera ${ }^{2}$ and Noelia Betoret ${ }^{2, *}$
}

1 Grupo de Valoración y Aprovechamiento de la Biodiversidad, Universidad Tecnológica del Chocó. AA.292, Calle 22 No. 18B-10, Quibdó-Chocó, CP. 270001 Colombia; leihicor@doctor.upv.es

2 Institute of Food Engineering for Development, Universitat Politècnica de València, CP 46022 València, Spain; steduase@etsiamn.upv.es (S.D.S.); lusegil@upvnet.upv.es (L.S.); mcbarpu@tal.upv.es (C.B.)

* Correspondence: noebeval@tal.upv.es; Tel: +34963877000 (83624).

Foods 2020, 9(6), 723

\begin{abstract}
The stabilization of fruit bagasse by drying and milling technology is a valuable processing technology to improve its durability and preserve its valuable biologically active components. The objective of this study was to evaluate the effect of lyophilization and air temperature $\left(60^{\circ} \mathrm{C}\right.$ and $\left.70{ }^{\circ} \mathrm{C}\right)$ in hot air-drying as well as grinding conditions (coarse or fine granulometry) on physico-chemical properties; water interaction capacity; antioxidant properties; and carotenoid content of powdered lulo bagasse. Air-drying kinetics at $60{ }^{\circ} \mathrm{C}$ and $70{ }^{\circ} \mathrm{C}$ and sorption isotherms at $20{ }^{\circ} \mathrm{C}$ were also determined. Results showed that drying conditions influence antioxidant properties and carotenoid content while granulometry slightly influenced fiber and water interaction properties. Fiber content was near $50 \%$ and carotenoid content was higher than $60 \mu \mathrm{g} / \mathrm{g}$ dry matter in lyophilized powder. This $\beta$-carotene content is comparable to that provided by carrot juice. Airdrying at $60{ }^{\circ} \mathrm{C}$ only reduced carotenoids content by $10 \%$.
\end{abstract}


Keywords: fruit by-products; lulo bagasse powder; dehydration; fiber; antioxidant properties; carotenoids

\section{Introduction}

Lulo (Solanum quitoense Lam) is one of the most important tropical fruits in Colombia. According to the report by the Ministry of Agriculture and Rural Development of Colombia (2017), Colombia is the third ranked country in Latin America with the largest number of hectares cultivated with fruit. The lulo harvest from different varieties, covering 10,539 hectares, has increased from 67,473 tons in 2012 to 79,872 tons in 2017 [1]

In recent years, lulo fruit has raised much interest in the global market due to its organoleptic characteristics, pleasant aroma, acidic and refreshing taste [2] and its high content of bioactive components such as fiber, minerals (phosphorus, calcium, iron), vitamins (thiamin, riboflavin, vitamin C), and other specific compounds (carotenes, lutein, zeaxanthin, chlorogenic acid, and bioactive amines) [3]. Moreover, a recent study has demonstrated the antihypertensive effect of compounds present in its juice and responsible for its bitter taste. These compounds are identified as bioactive amines $\mathrm{N}^{1}, \mathrm{~N}^{4}, \mathrm{~N}^{8}$ tris-(Dihydrocafeoyl), spermidine, and $\mathrm{N}^{1}, \mathrm{~N}^{8}$-bis-(Dihydrocafeoyl) spermidine [4].

Studies about the uses of the lulo fruit in the food industry are scarce. Lulo fruit is consumed as juice, in desserts, and for jellies; processed to make frozen concentrated juice and tea infusions as well as fermented for the elaboration of alcoholic beverages. In Colombia, it is the main ingredient for making the Lulada fruit cocktail liquor such as Ecuador's Canelazo and Colada Morada cocktail drinks. Juice production is the most frequently industrialization option. However, a large number of by-products are produced with associated environmental problems. According to data from [5], around 9.76 million tons of fruit and vegetable by-products are generated every year. Lulo bagasse includes the fruit skin as well as traces of pulp and seeds. Traditional utilization for such food industry by-products include feed for livestock, fertilizers, or agricultural substrates [6]. However, these uses do not provide adequate added value when considering the valuable active components contained in the by-products. 
The stabilization of fruit bagasse by drying and milling technology is a valuable processing technology to improve its durability and preserve its biologically active components. Chemical composition and structural characteristics of raw material largely determine physico-chemical and functional properties of the final powder [7]. Powders obtained can be used as a healthy natural ingredient or as a raw material to extract bioactive compounds for other uses. The effect of drying and milling technology has been studied in fruit pomaces such as apple, grapes, cherry, blackcurrant, strawberry, raspberry, or blackberry [8]. However, as far as we know, no study has been done to date with lulo bagasse. The objective of this study was to evaluate the effect of lyophilization and air temperature $\left(60^{\circ} \mathrm{C}\right.$ and $\left.70{ }^{\circ} \mathrm{C}\right)$ in hot air-drying as well as grinding conditions (coarse or fine granulometry) on physico-chemical, water interaction, and antioxidant properties of powdered lulo bagasse. The effect on the content of the three major carotenoids has been also evaluated.

\section{Materials and Methods}

\subsection{Lulo bagasse preparation}

Two kg of fresh lulo fruits (Solanum quitoense Lam.), equivalent to 89 pieces, from Colombia were purchased in the Central Market in València (Spain). Whole lulo fruits were washed, blended for $10 \mathrm{~min}$ in a domestic blender (Phillips Avance Collection Standmixer, $800 \mathrm{~W} 2 \mathrm{~L}$ ), and filtered with a stainless steel $500 \mu \mathrm{m}$ sieve. After filtering, lulo juice and a solid paste were separated. The solid paste, referred to as the lulo bagasse from now on, was labeled and stored at $4{ }^{\circ} \mathrm{C}$ in a freezer until further processing.

\subsection{Dehydration and milling of lulo bagasse}

Lulo bagasse was dehydrated by hot air-drying and lyophilization. Hot air-drying was carried out in a convective dryer (Pol-eko Aparatura, Katowice, Poland) at $60{ }^{\circ} \mathrm{C}$ and $70{ }^{\circ} \mathrm{C}$ until aw $\leq 0.3$ was achieved. Lyophilization was performed in a lyophilizer (Telstar, Lioalta-g) at 0.05 mbar for $24 \mathrm{~h}$ after samples were frozen at $-40^{\circ} \mathrm{C}$.

Dehydrated lulo bagasse was milled in a domestic food processor (Thermomix ${ }^{\oplus}$ Vorwerk, Spain) to obtain two different granulometries (fine and coarse). Fine granulometry resulted from milling at 10,000 rpm for $2 \mathrm{~min}$ in $20 \mathrm{~s}$ intervals and the coarse one by milling at $4000 \mathrm{rpm}$ for $20 \mathrm{~s}$ and, 
subsequently at $10,000 \mathrm{rpm}$ for $20 \mathrm{~s}$ in $5 \mathrm{~s}$ intervals. Fine and coarse lulo bagasse powders were stored in opaque glass jars in conditions of controlled relative humidity.

\subsection{Analytical determinations}

Water activity was measured with a dew point hygrometer (Aqualab 4TE Decagon devices Inc. Pullman, WA, USA) at the temperature of $20^{\circ} \mathrm{C}$. Moisture content was measured by drying until constant weight was achieved [9]. Total soluble solids content was determined in an ABBE ATAGO 3-T refractometer thermostated at $20^{\circ} \mathrm{C}$. Before the measurement, dried samples were water diluted in the proportion $1: 10(\mathrm{~g} / \mathrm{mL})$. Fiber content was determined following the Van Soest method as described by Mertens et al. [10] Neutral detergent fiber, acid detergent fiber, and lignin detergent fiber were analyzed and cellulose, hemicellulose, and lignin were calculated from those results.

\subsection{Water interaction and emulsifying properties}

Solubility as the mass fraction of dissolved material during powder rehydration was determined following the procedure described by Mimouni et al. [11].

Hygroscopicity, defined as the capability of a product to adsorb water, was evaluated according to the Cai and Corke [12] method by weighing $0.5 \mathrm{~g}$ of each sample and taking them to an airtight chamber next to a saturated solution of sodium sulfate $\left(\mathrm{Na}_{2} \mathrm{SO}_{4}\right)$.

Wettability or the time taken by the powders to get completely wet was assessed by weighing $2 \mathrm{~g}$ of sample in a beaker with $20 \mathrm{~mL}$ of distilled water at $25^{\circ} \mathrm{C}[13]$.

Swelling capacity is defined as the ratio between the volume that a sample occupies after hydration for a certain time and the original weight of the sample $[14,15]$. One gram of sample was weighed in a graduated conical tube, to which $10 \mathrm{~mL}$ of water was added to hydrate the sample for $18 \mathrm{~h}$ at 25 ${ }^{\circ} \mathrm{C}$.

Water holding capacity or water bound by gravity at atmospheric pressure was determined by measuring water content of the precipitate after 
mixing $0.2 \mathrm{~g}$ of sample and $10 \mathrm{~mL}$ of distilled water and left to stand for $18 \mathrm{~h}$ at $25^{\circ} \mathrm{C}[14]$.

Water retention capacity is defined as water content remaining bond after hydration and centrifugation. $1 \mathrm{~g}$ of sample was weighed in a conical centrifuge tube and $10 \mathrm{~mL}$ of water was added, allowing hydration for $18 \mathrm{~h}$ at $25{ }^{\circ} \mathrm{C}$. After that, samples were centrifuged for $30 \mathrm{~min}$ at $514 \times \mathrm{g}$. The precipitate was weighed and lyophilized to obtain the dry weight of the sample [14].

Oil retention capacity was measured following the method described by Garau et al. [16]. A $0.2 \mathrm{~g}$ of sample was mixed with $1.5 \mathrm{~g}$ of sunflower oil at room temperature. After that, the mixture was centrifuged at $1500 \times g$ for 5 min, the supernatant was removed, and the precipitate was weighted. Oil retention capacity was expressed in grams of absorbed oil per gram of initial sample.

Emulsifying activity was determined by the method described by Yasumatsu et al. [17]. A $2 \%(w / v)$ aqueous solution was prepared with the sample in a graduated tube. Seven $\mathrm{mL}$ of the prepared solution was mixed with $7 \mathrm{~mL}$ of sunflower oil and homogenized for $5 \mathrm{~min}$ in a vortex at $2400 \mathrm{rpm}$. After that, the mix was centrifuged at $12,857 \times \mathrm{g}$ for $5 \mathrm{~min}$. The volume of the emulsion was measured and referred to the total fluid volume. The emulsifying stability was determined by a similar procedure explained for emulsifying activity, except that the emulsions were heated at $80^{\circ} \mathrm{C}$ for $30 \mathrm{~min}$ before centrifugation at $514 \times g$ for $5 \mathrm{~min}$.

\subsection{Particle size}

Particle size was determined on wet and dry dispersions. In both cases, laser diffraction equipment (Mastersizer, Malvern Instruments Limited, Worcerster, Great Britain) was used with a short-wavelength blue light source in conjunction with forward and backscatter detection to enhance sizing performance in the range 0.01-1000 $\mu \mathrm{m}$. For the wet measurement, a small quantity of each sample was diluted in deionized water until it reached an obscuration of $8-9 \%$. For the dry measurement, a small amount of each sample was put directly into the equipment until it reached an obscuration of 8-9\%. Particle size distribution measurements were characterized through average equivalent volume diameter $\mathrm{D}[3,4]$. 


\subsection{Optical properties}

CIE* $L^{*} a * b *$ color coordinates were determined from the surface reflectance spectra obtained between 400 and $700 \mathrm{~nm}$, when measuring on white and black backgrounds, considering standard light source D65 and standard observer $10^{\circ}$ (Minolta spectrophotometer CM-3600d, Japan).

\subsection{Antioxidant properties}

For antioxidant extraction, the samples were mixed with an 80:20 $(v / v)$ methanol-water solution in the proportion 1:10 $(w / v)$ and centrifuged at $10,000 \mathrm{rpm}$ for $5 \mathrm{~min}$ at $20^{\circ} \mathrm{C}$ (Selecta, "Medrifriger BL-S"). The next analyses were carried out in the supernatant.

\subsection{Total phenols and flavonoids content}

Total phenols were determined following the Folin-Ciocalteu method $[18,19]$. A sample of the $0.125 \mathrm{~mL}$ of extract, $0.125 \mathrm{~mL}$ of Folin-Ciocalteu reagent (Sigma-Aldrich), and $0.5 \mathrm{~mL}$ of double-distilled water were mixed and allowed to react for $6 \mathrm{~min}$. After that, $1.25 \mathrm{~mL}$ of $7 \%(\mathrm{~m} / \mathrm{v})$ sodium carbonate solution and $1 \mathrm{~mL}$ of double distilled water were added. Absorbance was measured in a spectrophotometer (Thermo Scientific, Helios Zeta U/Vis) at $765 \mathrm{~nm}$. A blank was used as a reference and allowed to react for $90 \mathrm{~min}$. A standard gallic acid curve ranging from 0 to $500 \mathrm{mg} / \mathrm{L}$ was obtained to express results in milligrams of gallic acid equivalent (GAE) per gram of dry sample.

Flavonoid content was determined following the method described by Luximon-Ramma et al. [20] A $1.5 \mathrm{~mL}$ sample of extract and $1.5 \mathrm{~mL}$ of a $2 \%(w / v)$ aluminum chloride solution were mixed and left in the dark for $10 \mathrm{~min}$. Absorbance was measured on a spectrophotometer (Thermo Scientific, Helios Zeta U/Vis) at $368 \mathrm{~nm}$. The resulting data were compared to a standard quercetin curve ranging from 0 to $350 \mathrm{mg} / \mathrm{L}$. The results were expressed in milligrams of quercetin equivalent (EQ) per gram of dry sample.

\subsection{DPPH and ABTS methods}

Antioxidant capacity was determined following the DPPH (2,2-diphenyl1-picrylhydrazyl) method described by Kuskoski et al. [21] and Stratil et al. [22], with some modifications. A total of $0.1 \mathrm{~mL}$ of the extract, $0.9 \mathrm{~mL}$ of 
methanol, and $2 \mathrm{~mL}$ of the methanol-DPPH solution were mixed and absorbance was measured at $517 \mathrm{~nm}$ in a spectrophotometer (Thermo Scientific, Helios Zeta U/Vis). The results were expressed as milligrams of Trolox equivalent (TE) per gram of dry matter, using the Trolox calibration curve within a 0 to $500 \mathrm{mg} / \mathrm{L}$ concentration range.

The antioxidant activity was also evaluated following the ABTS (2,2'azino-bis(3-ethylbenzothiazoline-6-sulfonic acid) radical method described by Re et al. [23]. A solution of $7 \mathrm{mM}$ of ABTS and $2.45 \mathrm{mM}$ of potassium persulfate was prepared and left to stand in the dark at room temperature for $16 \mathrm{~h}$. ABTS was mixed with phosphate buffer to reach an absorbance of $0.70 \pm 0.02$, read at $734 \mathrm{~nm}$. A $0.1 \mathrm{~mL}$ of extract was added to $2.9 \mathrm{~mL}$ of ABTS solution and absorbance was measured at $734 \mathrm{~nm}$ in a spectrophotometer (Thermo Scientific, Helios Zeta UV/Vis) after 0, 3 and 7 min of reaction time. The results were expressed as mg of Trolox equivalent (TE) per gram of dry matter.

\subsection{Carotenoid content by HPLC (High-Performance Liquid Chromatography)}

Carotenoids were extracted according to the procedure described by Rodrigues et al. [24] and Bunea et al. [25], with some modifications. One gram of sample was mixed with methanol/ethyl acetate/petroleum ether (1:1:1, $v / v / v)$ as the extraction solvent. The extract was saponified for $12 \mathrm{~h}$ in the dark at room temperature, using a $30 \%(v / v) \mathrm{KOH}$ solution in methanol. The sample was washed with saturated saline solution, evaporated in a rotary evaporator $\left(\mathrm{T}<30^{\circ} \mathrm{C}\right)$, and analyzed by HPLC. HPLC analysis was performed in a HPLC Alliance 2995 system, using a separation module (Waters, 2695) made up of a pump and a DAD detector (2996, Waters, Milford, MA, USA). Carotenoids were separated with a YMC C30 column [5 $\mu \mathrm{m}, 250 \mathrm{~mm} \times 4.6 \mathrm{~mm}$ (internal diameter)], using ternary gradient elution made up of acetonitrile:water (9:1, $v / v$ ) with $0.25 \%$ trietylamine (solvent A) and ethyl acetate with $0.25 \%$ trietylamine (Solvent B). Carotenoids were quantified at a flow of $1 \mathrm{~mL} / \mathrm{min}$. The results were expressed in micrograms per $100 \mathrm{~g}$ of dry sample.

\subsection{Sorption isotherms}

Sorption isotherms were determined according to the method described by Wolfe et al. [26] with some modifications. This technique involves the use 
of saturated salt solutions to maintain a known and controlled humidity environment inside a closed jar at a fixed temperature condition. One gram of sample was placed in a closed jar together with one of the next saturated salt solutions: $\mathrm{LiCl}(\mathrm{aw}=0.1), \mathrm{CH}_{3} \mathrm{COOK}\left(\mathrm{aw}=0.23, \mathrm{MgCl}_{2}(\mathrm{aw}=0.32), \mathrm{K}_{2} \mathrm{CO}_{3}(\mathrm{aw}=\right.$ $0.43), \mathrm{Mg}\left(\mathrm{NO}_{3}\right)_{2}(\mathrm{aw}=0.52), \mathrm{NaCl}(\mathrm{aw}=0.75), \mathrm{KCl}(\mathrm{aw}=0.85)$, and $\mathrm{BaCl}_{2}(\mathrm{aw}$ $=0.90$ ) at $20^{\circ} \mathrm{C}$. The samples were weighed every eight days until constant weight was reached. Once the samples reached equilibrium, moisture content was measured.

\subsection{Statistical analysis}

All determinations were made in triplicate and the statistical analysis of the data was performed in a Statgraphics Centurion XVII software package, making use of a simple or multifactorial analysis of variance (ANOVA) at a 95\% confidence level $(p<0.05)$.

\section{Results}

\subsection{Hot air-drying of lulo bagasse}

Figure 1 shows the hot air-drying curves at $60{ }^{\circ} \mathrm{C}$ and $70{ }^{\circ} \mathrm{C}$ and drying speed curves for lulo bagasse.

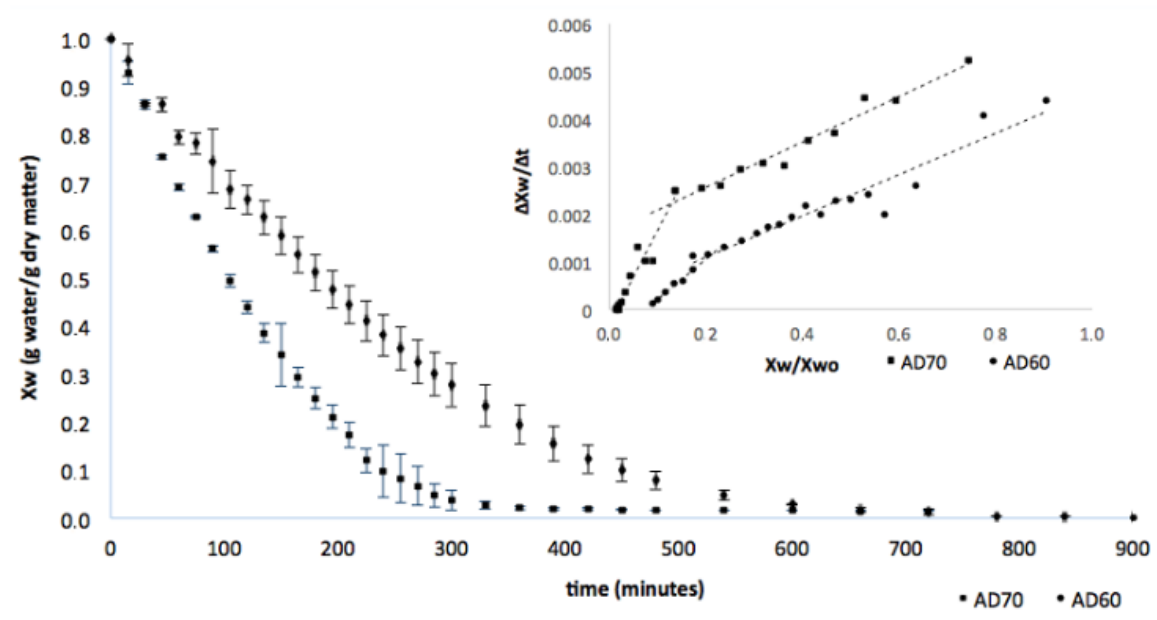

Figure 1. Hot air-drying and drying rate curves at $60{ }^{\circ} \mathrm{C}$ and $70{ }^{\circ} \mathrm{C}$ of lulo bagasse. AD60 and AD70: hot air-drying at $60^{\circ} \mathrm{C}$ and $70^{\circ} \mathrm{C}$, respectively. 
For a curve comparison, reduced humidity $\left(X_{w} / X_{w 0}\right)$ was used. An effect of air temperature on the kinetics of the process can be observed. Drying with air at $60{ }^{\circ} \mathrm{C}$ requires approximately $10-12 \mathrm{~h}$ until the product reaches an almost constant weight, which corresponds to a humidity close to $2 \%$. Increasing the temperature to $70{ }^{\circ} \mathrm{C}$ decreased the time required to 6-7 h. Although when obtaining a functional food ingredient, it is necessary to consider the effect of air-drying temperature on bioactive compounds (antioxidants such as carotenoids in lulo powder), the effect on processing time, production, and energy consumption will be relevant when it comes to setting up an industrial process. In Figure 1, it can be observed that an increase in the air-drying temperature resulted in greater values of drying rates that decreased along all the air-drying process. Experimental values were linearly adjusted to model equation showed at Table 1 . Two stages with different kinetics were clearly identified. Kinetic parameters obtained for each stage at both temperatures and correlation coefficients $\left(R^{2}\right)$ are included in Table 1.

Table 1. Kinetics of air drying of lulo bagasse at $60^{\circ} \mathrm{C}$ and $70^{\circ} \mathrm{C}$

\begin{tabular}{|c|c|c|}
\hline & $60^{\circ} \mathrm{C}$ & $70^{\circ} \mathrm{C}$ \\
\hline First stage: $\frac{\Delta X w}{\Delta t}=k_{1} \frac{X w}{X w_{0}}+k_{2}$ & $\frac{X w}{X w_{0}} \in[1,0.195]$ & $\frac{X w}{X w_{0}} \in[1,0.129]$ \\
\hline $\mathrm{k}_{1}$ & 0.0043 & 0.0048 \\
\hline $\mathrm{k}_{2}$ & 0.0002 & 0.0016 \\
\hline $\mathrm{R}^{2}$ & 0.9176 & 0.9625 \\
\hline Second stage: $\frac{\Delta \mathrm{Xw}}{\Delta \mathrm{t}}=\mathrm{k}_{1}^{\prime} \frac{\mathrm{Xw}}{\mathrm{Xw}_{0}}+\mathrm{k}_{2}^{\prime}$ & $\frac{X w}{X w_{0}} \in[0.195,0.089]$ & $\frac{X w}{X w_{0}} \in[0.129,0.024]$ \\
\hline $\mathrm{k}_{1}^{\prime}$ & 0.0084 & 0.0195 \\
\hline$k_{2}^{\prime}$ & -0.0006 & -0.0003 \\
\hline $\mathrm{R}^{2}$ & 0.987 & 0.9319 \\
\hline
\end{tabular}

Xw: moisture content; $\mathrm{Xw}_{0}$ : initial moisture content.

In the first stage, the decline of drying rate was not affected by air temperature. Considering that in the drying chamber the relation between air volume and the mass of lulo bagasse was large enough to avoid changes in the air conditions, the lack of temperature effect on the decline of drying rate revealed an internal control. Structural characteristics and composition determine water molecular transport from the innermost layers to the surface 
of the solid bed. However, the drying kinetics change when the moisture of the product drops below $40 \%(w / w)$ at $60{ }^{\circ} \mathrm{C}$ and below $30 \%(w / w)$ at $70{ }^{\circ} \mathrm{C}$ (these values are the result of considering a $X_{w 0}=3.4 \mathrm{~g}$ water/g dry matter and the relation $\frac{X w}{X_{w_{0}}}$ indicated in Table 1). From this humidity, decreasing the drying rate with moisture depends on the air temperature being more pronounced at $70{ }^{\circ} \mathrm{C}$. Phase transitions of some components, together with a greater compaction of the lulo bagasse bed would probably explain these differences.

\subsection{Moisture sorption isotherms of lulo powders}

The sorption isotherms at $20^{\circ} \mathrm{C}$ of the lulo bagasse powders are shown in Figure 2.
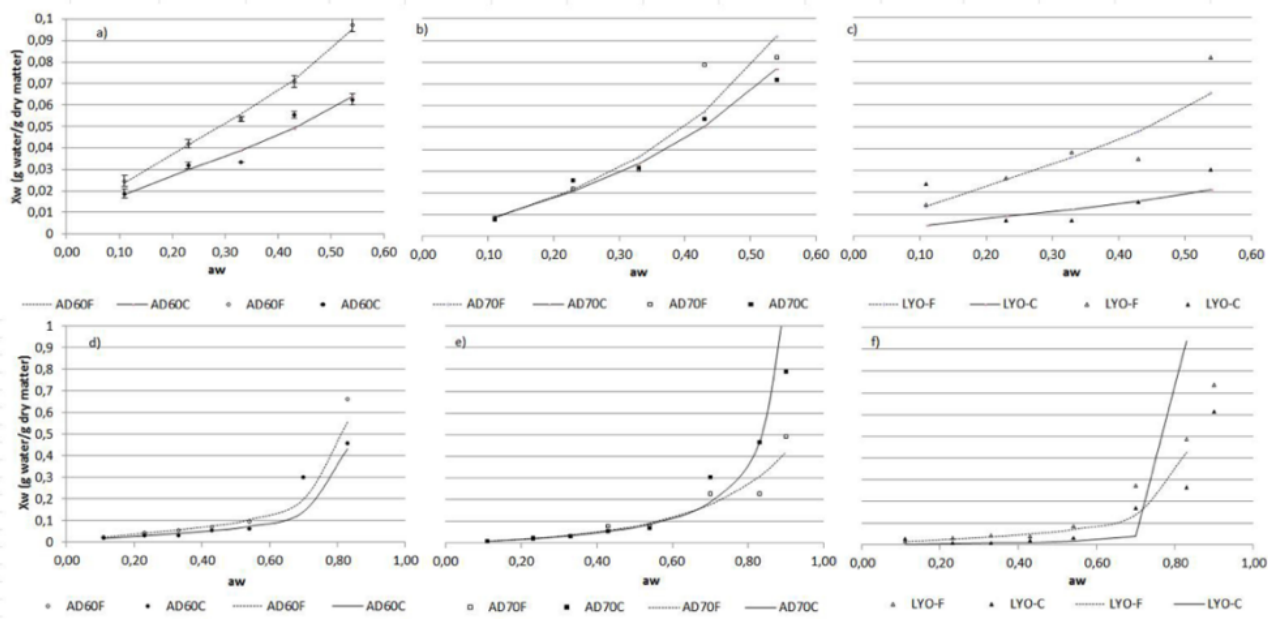

Figure 2. Sorption isotherms: experimental data and BET (Brunauer-Emmett-Teller) $(a, b, c)$ and GAB (Guggenheim-Anderson-de Boer) (d, e, f) adjustment.

The curves demonstrate an important increase in water activity with low increasing equilibrium moisture content, following the type II and III BET classification shape, which is usual for non-structured and non-porous solid foods [27]. It is the typical form of plant products rich in simple sugars such as fructose or glucose and macromolecules such as cellulose or hemicellulose, with low ability to adsorb water molecules. The curves are similar to that for dried persimmon leaves [28]. Figure 2 shows the agreement between the experimental data and predicted isotherms using BET (Brunauer-EmmettTeller) and GAB (Guggenheim-Anderson-de Boer) models. Model parameters and correlation coefficients $\left(\mathrm{R}^{2}\right)$ are included in Table 2 . The BET model was 
adjusted considering aw values below 0.55, which is consistent with the assumptions assumed by the model [29]. GAB model setting has included values up to 0.8 .

Table 2. Parameters from BET and GAB adjustment.

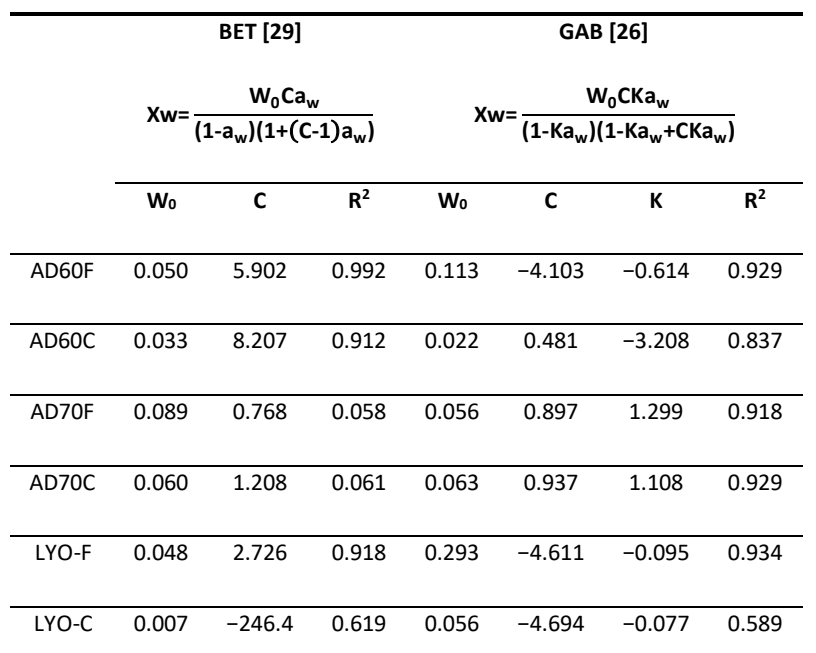

AD60, AD70: hot air drying at $60{ }^{\circ} \mathrm{C}$ and $70{ }^{\circ} \mathrm{C}$ respectively; LYO: lyophilized; $\mathrm{F}$ : fine granulometry; $\mathrm{C}$ : coarse granulometry.

Among all sorption isotherm model parameters, the monolayer moisture content is recognized as the most important one. It corresponds to the moisture content affording the longest storage time period with minimum quality loss by deteriorative reactions (except fat oxidation) at a given temperature. From a physico-chemical point of view, it is related to the number of sorption sites available on the material surface. Therefore, the conditions of milling or drying inducing changes in surface structural characteristics are expected to lead to changes in monolayer moisture content. Furthermore, the physical state (crystalline or amorphous) in which the food components are found and the phase transitions along the dehydration process conditioned by temperature and kinetics, strongly influence water retention.

A lower variability and greater consistency in the monolayer moisture values can be observed in Table 2, as obtained from the BET model. The values were slightly higher in the fine powder than in the coarse one, probably because the fine powder had a larger specific surface, having a greater number of accessible active points. Lyophilized powders showed lower values, which can be associated with a greater disruption of cell structure that occurs during 
this treatment. The greatest difference between the air-dried powders at 60 ${ }^{\circ} \mathrm{C}$ and $70^{\circ} \mathrm{C}$ is given by the value of parameter $\mathrm{C}$. It is an empirical parameter directly related to the net heat of sorption being the difference between the heat of sorption of the first layer of molecules of water and the others. It is considered that $\mathrm{C}$ values greater than 2 are associated with higher adsorption forces (type II sorption isotherms corresponding to dried powders at $60{ }^{\circ} \mathrm{C}$ ). The differences obtained between air-dried powders at $60^{\circ} \mathrm{C}$ or $70{ }^{\circ} \mathrm{C}$ could be related to the effect of temperature on the kinetics of the process and the associated phase transitions.

\subsection{Physico-chemical properties}

Table 3 shows the total soluble solids content ( $\left.x_{s s}\right)$, water activity (aw), and moisture content $\left(x_{w}\right)$ of different lulo bagasse powders. All drying conditions allow for reducing the aw below 0.27 , which is considered a usual value in food powders such as milk powder or instant coffee [30]. Corresponding moisture contents were also very low, the drying process having contributed to reducing most of the free water content responsible for spoilage reactions. Statistically significant differences among treatments were detected for the three parameters, the differences being lower between fine and coarse powders. The most significant differences appeared between the two temperatures of hot air-drying. These differences manifested themselves similarly in the water activity and in the moisture content of the samples, so they are associated with the effect of temperature on the desorption characteristics of the samples determined by air-drying kinetics and phase transitions along the process. 
Table 3. Water activity $\left(a_{w}\right)$, moisture content $\left(x_{w}\right)$, (g water/g), soluble solids content $\left(x_{s s}\right)$ (g soluble solids/g), fiber content (\% of dry weight) and CIE L*a*b* coordinates of lulo bagasse powders. Mean \pm standard deviation of three repetitions.

\begin{tabular}{|c|c|c|c|c|c|c|}
\hline $\mathbf{x}_{\mathrm{ss}}\left(\mathrm{g}_{\mathrm{ss}} / \mathrm{g}_{\text {total }}\right)$ & $0.236 \pm 0.005^{\mathrm{e}}$ & $0.149 \pm 0.012^{\mathrm{a}}$ & $0.222 \pm 0.006^{\mathrm{b}}$ & $0.146 \pm 0.06^{c}$ & $0.21 \pm 0.11^{b}$ & $0.26 \pm 0.14^{d}$ \\
\hline Hemicellulose (\%) & $5.2 \pm 0.2^{\mathrm{a}}$ & $11.3 \pm 0.2^{\mathrm{e}}$ & $5.5 \pm 0.2^{\mathrm{a}}$ & $11.30 \pm 0.4^{c}$ & $10.3 \pm 0.2^{b}$ & $10.7 \pm 0.4^{\mathrm{bc}}$ \\
\hline Cellulose (\%) & $18.6 \pm 0.3^{\mathrm{a}}$ & $24.7 \pm 0.4^{c}$ & $21.3 \pm 0.7^{b}$ & $24.59 \pm 0.05^{c}$ & $22.1 \pm 0.2^{b}$ & $24.6 \pm 0.3^{c}$ \\
\hline Lignin (\%) & $10.1 \pm 0.3^{\mathrm{a}}$ & $20.84 \pm 3^{b}$ & $17.6 \pm 0.23^{\mathrm{a}}$ & $10.6 \pm 0.2^{\mathrm{a}}$ & $8.5 \pm 0.5^{b}$ & $10.8 \pm 0.4^{\mathrm{a}}$ \\
\hline Insoluble fiber (\%) & $35.2 \pm 0.1^{b}$ & $40.3 \pm 0.4^{d}$ & $33.3 \pm 0.2^{\mathrm{a}}$ & $34.2 \pm 0.2^{\mathrm{ab}}$ & $38.4 \pm 0.3^{c}$ & $41.65 \pm 1.01^{\mathrm{e}}$ \\
\hline Total fiber (\% & $42.6 \pm 0.04^{b}$ & $50.6 \pm 0.6^{f}$ & $41.4 \pm 0.4^{\mathrm{a}}$ & $46.5 \pm 0.3^{c}$ & $46.0 \pm 0.4^{d}$ & $48.1 \pm 0.3^{\mathrm{e}}$ \\
\hline \multicolumn{7}{|c|}{ Colour } \\
\hline $\mathbf{L}^{*}$ & $58.4 \pm 0.2^{c}$ & $50.8 \pm 0.2^{b}$ & $53.3 \pm 0.3^{c}$ & $50.97 \pm 0.06^{b}$ & $63.134 \pm 0.13^{d}$ & $60.59 \pm 0.05^{d}$ \\
\hline$a^{*}$ & $10.37 \pm 0.02^{c}$ & $10.22 \pm 0.07^{c}$ & $10.35 \pm 0.11^{c}$ & $10.76 \pm 0.13^{d}$ & $9.46 \pm 0.07^{\mathrm{a}}$ & $9.98 \pm 0.05^{b}$ \\
\hline $\mathbf{b}^{*}$ & $38.22 \pm 0.11^{d}$ & $40.5 \pm 0.3^{f}$ & $39.5 \pm 0.2^{\mathrm{e}}$ & $38.043 \pm 0.10^{d}$ & $36.74 \pm 0.11^{c}$ & $34.57 \pm 0.06^{b}$ \\
\hline C & $39.60 \pm 0.01^{d}$ & $42.6 \pm 0.3^{f}$ & $40.8 \pm 0.2^{\mathrm{e}}$ & $39.53 \pm 0.12^{d}$ & $37.94 \pm 0.09^{c}$ & $35.98 \pm 0.06^{\mathrm{a}}$ \\
\hline h & $74.84 \pm 0.07^{c d}$ & $71.92 \pm 0.04^{b}$ & $75.32 \pm 0.09^{d}$ & $74.2 \pm 0.2^{c}$ & $75.56 \pm 0.14^{d}$ & $73.70 \pm 0.02^{c}$ \\
\hline
\end{tabular}

$L^{*}$ : brightness; $a^{*}$ : red -green; b*: yellow-blue; AD60, AD70: hot air drying at $60^{\circ} \mathrm{C}$ and $70{ }^{\circ} \mathrm{C}$ respectively; LYO: lyophilized; F: fine granulometry; C: coarse granulometry. ${ }^{a, b, c . . .}$ different letters on the same file indicate statistically significant differences at a $95 \%$ confidence level. 
The different fiber fractions of lulo bagasse powders determined by the Van Soest method are summarized in Table 3. This method estimates the structural carbohydrates and indigestible substances linked to them that form the plant cell wall. Although the determination quantifies the fractions of hemicellulose, cellulose, and lignin, it does not allow for the quantification of components such as pectins and other polysaccharides that are also part of the dietary fiber. It is essentially the soluble fiber that is undervalued in the Van Soest method. It can be observed that the total fiber content varied from $34 \%$ to $47 \%$ being amounts lower than the dietary fiber obtained for other fruit waste powders such as pomegranate bagasses (45.6-50.3 g/100 g dry weight) [31], grape co-products (74.5 g/100 g dry weight) [32], apple pomace $(51.1 \mathrm{~g} / 100 \mathrm{~g}$ dry weight) [33], or banana peels ( $49.9 \mathrm{~g} / 100 \mathrm{~g}$ dry weight) [34]. However, the total fiber content is similar to that for other fruits by-products such as grapefruit peel (44.2\%) [35], mango (37.1\%), and peach (37.6\%) by-products [36]. Larrauri et al. [37] stated that products containing $50 \%$ of total fiber can be considered as a source rich in fiber. According to the Scientific Opinion on Dietary Reference Values [38], a daily dietary intake of at least $25 \mathrm{~g}$ of fiber is recommended. However, nutritionists recommend a daily fiber intake of $35 \mathrm{~g}$ per day [39]. It can be observed that in the three drying treatments, and practically for all fiber fractions, there are statistically significant differences between fine granulometry and coarse granulometry powders. This can be explained by the effect of milling and particle size reduction. Although health claims for fiber do not distinguish between insoluble and soluble fractions, it is accepted that the 'ideal dietary fiber' should have a balanced composition (insoluble and soluble fractions) [37]. Other authors accept that fiber sources suitable for use as food ingredients should have a ratio soluble to insoluble close to $1: 2$ to provide adequate physiological effects [40]. The results obtained for the lulo bagasse powders showed a much higher relationship between hemicellulose (part of the soluble fiber) and the insoluble fiber, although as previously mentioned, the Van Soest method used does not allow for the determination of other soluble fiber components.

Figure 3 shows the particle size distribution of lulo bagasse powders by the dry and wet methods. The particle size distribution of lulo bagasse powders by the dry method did not show remarkable differences between treatments. 

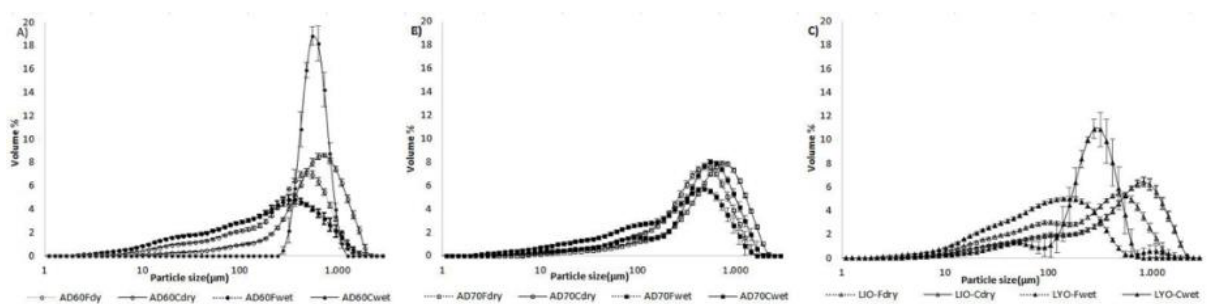

Figure 3. Particle size distribution of lulo bagasse powders by the dry method (empty markers) and wet method (full markers). A: AD60: hot air-drying at $60^{\circ} \mathrm{C}$; B: AD70: hot air-drying at 70 ${ }^{\circ} \mathrm{C}$; C: LYO: lyophilized; F: fine granulometry; C: coarse granulometry.

A particle volume maximum appeared at $1000 \mu \mathrm{m}$ for all treatments and a minor maximum at $100 \mu \mathrm{m}$ only for the lyophilized powders. Conversely, the dehydration treatment applied largely determined the particle size distribution by the wet method. In the powders dehydrated by hot air at $60^{\circ} \mathrm{C}$ (Figure $3 \mathrm{~b}$ ) and regardless of granulometry, no large changes in distribution were observed. Only a slight increase in the number of smaller particles (around $100 \mu \mathrm{m}$ ) was observed due to the solubilization of a part of the particles sized around $1000 \mu \mathrm{m}$. However, in the samples dried by hot air at $70{ }^{\circ} \mathrm{C}$ and lyophilized, the granulometry largely determined the changes in the distribution obtained by wet way (Figure $3 a, c$ ). In fine granulometry powders, the changes were very similar to those obtained for drying at $60^{\circ} \mathrm{C}$, with a shift in the distribution toward smaller particle sizes. This shift was more pronounced in the powders obtained by lyophilization, probably due to the higher solubility associated with increased porosity of the particles in this treatment. However, in coarse granulometry powders, the appearance of a much more pronounced peak at a particle size slightly smaller than $1000 \mu \mathrm{m}$ was observed, reflecting an aggregation of smaller particles (Figure 3).

Table 3 includes $L^{*} a * b *$ coordinates and $h$ and $C$ parameters of the powders. For the luminosity values $\left(L^{*}\right)$, a significant decrease could be observed in the air-dried powders compared with the lyophilized ones. Regarding the parameters $a^{*}$ and $b^{*}$, which represent (+red/green-) and (+yellow/blue-) respectively, all the values were found to be positive. Both parameters were significantly lower for lyophilized powders, while the differences among the air-dried ones were slight. Among the air-dried powders, differences between fine and coarse granulometry were higher than those caused by air temperature. Formation of brown compounds as a result of the Maillard reaction in air-dried powders is favored by the major exposure to oxygen in fine powders. Lyophilization greatly reduces the Maillard 
reactions [41]. As a result, air-dried powders tend to have a browner color and the lyophilized ones are a greenish color more similar to the fresh bagasse.

\subsection{Water interaction and emulsification properties of lulo bagasse powders}

Solubility is a physical property describing powder behavior in an aqueous solution. For fiber rich ingredients such as powders from fruit byproducts, it mainly depends on fiber content, size, and physical characteristics of particles (porosity and physical stage of components). The solubility of lulo bagasse powders is included in Table 4.

Values were similar to that obtained for orange peel by Garau et al. [16], but higher to that obtained for tomato powders by Santos de Sousa et al. [42]. Statistical analysis showed granulometry (fine or coarse) as the most important factor determining significant differences $(p<0.05)$ among the samples. These results are consistent with those obtained for fiber content. The greater intensity of the milling treatment applied in fine powders produces a smaller particle size, a reduction in the content of the different insoluble fiber fractions, and therefore a greater solubility. Regarding the effect of the dehydration treatment, the lyophilized samples showed higher solubility levels, as a consequence of the more aggressive structural breaks suffered by the samples due to the sublimation of the water contained within the tissue. The decrease in solubility caused by temperature increase in hot air-dried samples could be due to the degradation of pectin substances and physical changes affecting other components during the drying process. Hygroscopicity is defined as the capability of a product to adsorb water $[43,44]$, and describe that a powder with low hygroscopicity, low humidity, low caking, and high solubility can be considered stable. The results obtained showed that hygroscopicity slightly decreased as the drying temperature increased. According to Ahmed et al. [45], powder moisture variations have a direct impact on hygroscopicity. Regarding swelling capacity, water holding, and retention capacities, they depend on microstructural properties of particles and the nature of the fiber content (soluble or insoluble).

Porous particles and soluble fibers have a high water holding capacity and swelling to form viscous solutions. Insoluble fibers can also adsorb and retain water within their fibrous matrix, but to a lesser extent. Lecumberri et al. [46] 
provides data on the swelling and water holding capacity of cellulose (insoluble fiber) and apple and orange pectin (soluble fiber), showing undetected or practically null values in the case of cellulose. The swelling value obtained for apple pectin $(7.42 \pm 1.15)$ was similar to that obtained for the lyophilized lulo bagasse powders and it was slightly lower in the hot air-dried ones. In all lulo bagasse powders, regardless of the dehydration treatment, water holding capacity was much lower than that for apple $(16.51 \pm 3.77)$ and orange $(28.07 \pm 5.37)$ pectin, although it was very similar to the value obtained for a fiber rich cocoa product. Additionally, for this property, the values were higher in lyophilized powders. According to Lecumberri et al. [47], wettability is strongly affected by size and porosity of particles. As a consequence of water sublimation, lyophilized powders showed a more porous particle surface, which makes water difficult to penetrate due to the greater surface tension that needs to be overcome. Wettability of lyophilized lulo bagasse powders showed much higher values than the air-dried ones.

Emulsifying properties concerning oil retention capacity and emulsifying activity and stability are required to use powders as an ingredient in fatty foods. These properties require the presence of long-chain chemical compounds with hydrophilic and hydrophobic groups. An effective emulsifying agent consists of water-soluble (hydrophilic) and water-insoluble (hydrophobic) domains. Pectin has an emulsifying capacity and has been traditionally used as a gelling and thickening reagent. Recently, reports of the remarkable emulsifying ability of pectin have attracted much attention, with sugar beet pectin [48] and pomegranate peel pectin [49] as examples. Nonconclusive results were obtained for emulsifying activity and stability of the powdered lulo bagasse. Oil retention capacity was very low and may be affected by the lower pectin content of the lulo bagasse. Similar powders from lemon, orange, peach, and apple bagasse have a greater oil retention capacity (contain 2.5 to $2.9 \mathrm{~g}$ of oil/g of sample), according to Martínez-Las Heras et al. [50]. 
Table 4. Hydration, water retention and emulsification properties of lulo bagasse powders. Mean \pm standard deviation of three repetitions

\begin{tabular}{|c|c|c|c|c|c|c|}
\hline & AD60F & AD60C & AD70F & AD70C & LYO-F & LYO-C \\
\hline Solubility (\%) & $35 \pm 5^{b}$ & $27 \pm 6^{b}$ & $32 \pm 2^{d}$ & $19 \pm 4^{c}$ & $45 \pm 8^{a}$ & $30 \pm 4^{c}$ \\
\hline $\begin{array}{l}\text { Higroscopicity (g } \mathrm{g}_{\text {water }} / \\
100 \mathrm{~g} \text { ) }\end{array}$ & $30.9 \pm 0.4^{c}$ & $23.0 \pm 0.2^{\mathrm{a}}$ & $23.0 \pm 0.2^{\mathrm{a}}$ & $22.7 \pm 1.1^{\mathrm{a}}$ & $22.1 \pm 0.20^{\mathrm{a}}$ & $\begin{array}{c}25.32 \pm \\
1.1^{\mathrm{b}}\end{array}$ \\
\hline Wettability (s) & $31.7 \pm 0.6^{b}$ & $8.7 \pm 1.2^{\mathrm{a}}$ & $10.0 \pm 1.0^{\mathrm{a}}$ & $11.0 \pm 1.7^{\mathrm{a}}$ & $19.5 \pm 2.6^{c}$ & $17.0 \pm 1.0^{\mathrm{b}}$ \\
\hline $\begin{array}{l}\text { Swelling capacity } \\
\left.\text { (mL } \mathrm{mLater}_{\text {w }} \mathrm{g}\right)\end{array}$ & $4.98 \pm 0.02^{b}$ & $4.46 \pm 0.04^{\mathrm{a}}$ & $4.97 \pm 0.02^{b}$ & $4.98 \pm 0.05^{b}$ & $7.46 \pm 0,05^{d}$ & $\begin{array}{c}5.48 \pm \\
0.02^{c}\end{array}$ \\
\hline $\begin{array}{l}\text { Water holding capacity } \\
\left.\text { (gwater } / g_{\text {dry matter }}\right)\end{array}$ & $5.89 \pm 0.10^{\mathrm{a}}$ & $5.7 \pm 0.1^{\mathrm{a}}$ & $6.3 \pm 0.2^{\mathrm{a}}$ & $7.6 \pm 0.8^{b}$ & $8.2 \pm 0.7^{b}$ & $6.4 \pm 0.5^{\mathrm{a}}$ \\
\hline $\begin{array}{c}\text { Water retention } \\
\text { capacity (gwater /gdry } \\
\text { matter) }\end{array}$ & $4.75 \pm 0.02^{\mathrm{a}}$ & $4.5 \pm 0.2^{\mathrm{a}}$ & $5.5 \pm 0.2^{b}$ & $5.83 \pm 0.06^{c d}$ & $5.9 \pm 0.1^{\mathrm{d}}$ & $5.9 \pm 0.4^{b c}$ \\
\hline \multicolumn{7}{|c|}{ Emulsifying properties } \\
\hline $\begin{array}{l}\text { Oil retention capacity } \\
\left(\mathrm{g}_{\text {oil }} / \mathrm{g}_{\text {sample }}\right)\end{array}$ & $0.142 \pm 0.004^{a}$ & $0.18 \pm 0.03^{\mathrm{ab}}$ & $0.20 \pm 0.02^{b c}$ & $0.20 \pm 0.02^{b}$ & $0.24 \pm 0.01^{c}$ & $\begin{array}{l}0.45 \pm \\
0.04^{d}\end{array}$ \\
\hline Emulsification activity & N.D & N.D & N.D & N.D & N.D & N.D \\
\hline Emulsification stability & N.D & N.D & N.D & N.D & N.D & N.D \\
\hline
\end{tabular}

AD60, AD70: hot air drying at $60{ }^{\circ} \mathrm{C}$ and $70{ }^{\circ} \mathrm{C}$, respectively; LYO: lyophilized; F: fine granulometry; C: coarse granulometry. a,b,c... different letters on the same column indicate statistically significant differences at a $95 \%$ confidence level. N.D: Not detected. 


\subsection{Antioxidant Properties}

Total phenol and flavonoid content are represented in Figure 4.
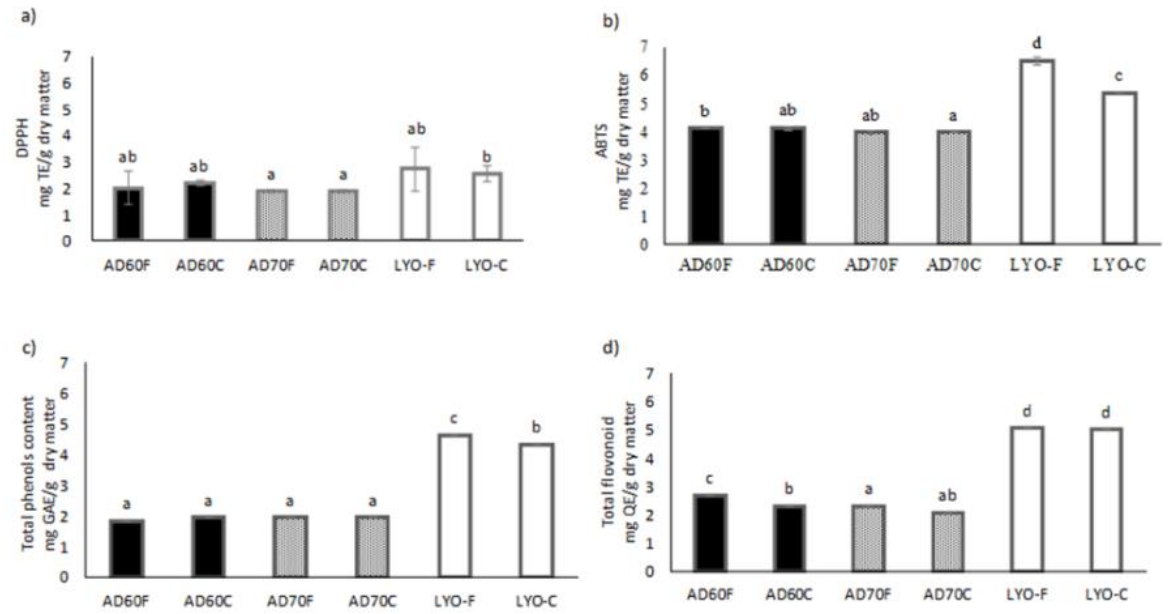

Figure 4. Antioxidant properties: results from DPPH method (a), results from ABTS method (b), total phenol content (c) and flavonoid content (d). AD60 and AD70: hot air-drying at $60{ }^{\circ} \mathrm{C}$ and $70^{\circ} \mathrm{C}$, respectively; LYO: lyophilized; F: fine granulometry; C: coarse granulometry.

Significant differences $(p<0.05)$ were observed between the hot airdried powders and lyophilized ones. The low temperature and vacuum conditions in the lyophilization treatment limit oxidation reactions, thus preserving phenolic and flavonoid compounds [51] Results were similar to those reported by Crozier et al. [52] in pomegranate powder and red fruits. Some other authors have also evaluated the effect of different drying techniques (mainly hot air-drying and lyophilization) in phenol and flavonoid content of different fruit by-products such as orange by-products [16], bagasse of blackcurrant pomace [53], mango peel [54], and apple peel [55]. The results exhibited, in all cases, a decrease in antioxidant compounds as the temperature increased.

Results of the antiradical capacity by the DPPH and ABTS methods are included in Figure 4. The use of more than one single method is recommended to estimate the antioxidant activity of complex samples [56]. In this case, the ABTS free radical method, which has been reported to be more sensitive to hydrophilic antiradicals [57], was used in addition to the DPPH radical method. In coherence with total phenol and flavonoid content, both methods 
showed slightly higher values for lyophilized lulo bagasse powders. However, the differences were more marked for the results obtained by the ABTS radical method. Additionally, for the hydrophilic nature of antioxidants compounds in the lulo bagasse powders, differences between the DPPH and ABTS methods were probably due to their different sensitivities to the antiradical compounds that may be present in the sugarcane products. The time of reactions could also have produced some differences; nevertheless, the ABTS reaction is usually faster than the DPPH inhibition reaction [56].

\subsection{Carotenoid content}

The $\beta$-cryptoxanthin, $\alpha$-carotene and $\beta$-carotene content of lulo bagasse powders are summarized in Table 5 .

Table 5. Carotenoids content ( $\mu \mathrm{g} / \mathrm{g}$ of dry sample) in the lulo bagasse powders.

Mean \pm standard deviation of three repetitions.

\begin{tabular}{|c|c|c|c|c|c|c|}
\hline & AD60F & AD60C & AD70F & AD70C & LYO-F & LYO-C \\
\hline$\beta$-cryptoxanthin & $4.761 \pm 0.014^{c}$ & $4.06 \pm 0.12^{b}$ & $1.197 \pm 0.008^{a}$ & $1.193 \pm 0.011^{a}$ & $8.83 \pm 0.04^{d}$ & $8.72 \pm 0.18^{d}$ \\
\hline$\alpha$-carotene & $1.60 \pm 0.07^{b}$ & $1.577 \pm 0.013^{b}$ & $0.546 \pm 0.017^{a}$ & $0.581 \pm 0.015^{a}$ & $1.75 \pm 0.01^{\mathrm{c}}$ & $1.73 \pm 0.03^{c}$ \\
\hline$\beta$-carotene & $45.2 \pm 0.4^{b}$ & $45.1 \pm 0.3^{b}$ & $27.8 \pm 0.3^{a}$ & $27.61 \pm 0.02^{a}$ & $61.85 \pm 0.25^{d}$ & $61.15 \pm 0.09^{c}$ \\
\hline Total & $51.5 \pm 0.5^{b}$ & $50.7 \pm 0.2^{b}$ & $29.51 \pm 0.2^{a}$ & $29.38 \pm 0.2^{a}$ & $72.6 \pm 0.4^{d}$ & $71.6 \pm 0.3^{c}$ \\
\hline
\end{tabular}

AD60 and AD70: Hot air-drying at 60 and $70{ }^{\circ} \mathrm{C}$, respectively; LYO: Lyophilized; F: Fine granulometry; C: Coarse granulometry. ${ }^{a, b, c . . .}$ different letters on the same file indicate statistically significant differences at a $95 \%$ confidence level.

A significant effect $(p<0.05)$ of dehydration treatment and air-drying temperature was observed, while the granulometry did not affect the results significantly. Lyophilized powders had the highest content in all of the components analyzed. In the hot air-dried powders, the increase in air temperature had, in all cases, a negative effect. These results highlight, once again, the relevance of lyophilized process to preserve nutraceutical components due to the low temperature and the absence of oxygen in the drying chamber $[41,58]$ quantified $\beta$-carotene in lyophilized by-products, showing lower values for guava by-product $(26.67 \mu \mathrm{g} / 100 \mathrm{~g}$ dry matter), mango $(58.26 \mu \mathrm{g} / 100 \mathrm{~g}$ dry matter), or passion fruit $(53.93 \mu \mathrm{g} / 100 \mathrm{~g}$ dry matter). Regarding the effect of temperature in hot air-drying, the results were consistent with those reported by Albanese et al. [59] They 
demonstrated hot air-drying at $50{ }^{\circ} \mathrm{C}$ as a suitable method and alternative to freeze-drying to preserve carotenoid compounds and antioxidant activity in tomato peels. Heating of the extracts up to $100{ }^{\circ} \mathrm{C}$ caused a progressive reduction of total carotenoids up to about $30 \%$ after 250 min of treatment. In lulo bagasse powders, hot air-drying at $60^{\circ} \mathrm{C}$ reduced the $\alpha$-carotene content by less than $10 \%$ and the $\beta$-carotene content by less than $30 \%$ compared to the lyophilized powder. Increasing the drying temperature to $70{ }^{\circ} \mathrm{C}$ increased the losses of the two components to values greater than $50 \%$. Although the hot air-drying treatment significantly reduced the content in the analyzed components, the beta-carotene content in the lyophilized powder was similar to the carrot juice provided by Bub et al. [60] in a human intervention study (330 $\mathrm{mL}$ of carrot juice providing $27.1 \mathrm{mg}$ of $\beta$-carotene) that demonstrated the beneficial effects of this component in reducing the oxidation of low density lipoproteins.

\section{Conclusions}

Lulo bagasse is a suitable raw material for obtaining a powder rich in fiber and carotenoids useful as an ingredient in the food industry. The imbalance in the ratio between soluble and insoluble fiber should be taken into account in subsequent applications.

Drying kinetics showed that in the first stage of the air-drying process, water molecular transport from the innermost layers to the surface of the solid bed was not affected by air temperature. Structural characteristics and the composition of bagasse determine an internal control. In this sense, the air temperature could be reduced in this stage with energy savings as a consequence.

The slight differences observed in the monolayer water content provided by isotherms for the different processing conditions, showed the expected high stability of lulo bagasse powders. Although differences in the $\mathrm{C}$ parameter showed important structural and physical changes along drying, physico-chemical characteristics such as color were not highly affected.

Both granulometry and dehydration conditions determine the properties of the final powder. A finer granulometry leads, independent of the dehydration conditions, to better water interaction properties and, especially to greater solubility. In relation to dehydration methods, lyophilization is the 
method that provides better antioxidant properties and a higher carotenoid content, although carotenoid content is also acceptable in hot air-drying at 60 ${ }^{\circ} \mathrm{C}$.

\section{Acknowledgments}

The authors thank the research project "Fortalecimiento de los Encadenamientos Productivos de las Subregiones del Chocó" BPIN 2013000100284 Tecnológica del Chocó (in Spanish) by financial support to Leidy Indira HinestrozaCórdoba.

\section{References}

1. Ministerio de Agricultura y Desarrollo Rural de Colombia Agronet Producción Nacional por Producto-Lulo. Available online:

https://www.agronet.gov.co/Paginas/ProduccionNacionalProducto.aspx (accessed on 24 February 2020).

2. Forero, D.P.; Orrego, C.E.; Peterson, D.G.; Osorio, C. Chemical and sensory comparison of fresh and dried lulo (Solanum quitoense Lam.) fruit aroma. Food Chem. 2015, 169, 85-91.

3. Gancel, A.L.; Alter, P.; Dhuique-Mayer, C.; Ruales, J.; Vaillant, F. Identifying carotenoids and phenolic compounds in naranjilla (Solanum quitoense Lam. var. Puyo hybrid), an Andean fruit. J. Agric. Food Chem. 2008, 56, 11890-11899.

4. Forero, D.P.; Masatani, C.; Fujimoto, Y.; Coy-Barrera, E.; Peterson, D.G.; Osorio, C. Spermidine derivatives in lulo (Solanum quitoense Lam.) fruit: Sensory (taste) versus biofunctional (ACE-inhibition) properties. J. Agric. Food Chem. 2016, 64, 5375-5383.

5. Departamento Nacional de Planeación de Colombia Colombianos Botan 9,76 millones de toneladas de Comida al año. Available online:

https://www.dnp.gov.co/Paginas/Colombianos-botan-9,76-millones-de-toneladas-decomida-al-año.aspx (accessed on 21 February 2020).

6. de Moraes Crizel, T.; Jablonski, A.; de Oliveira Rios, A.; Rech, R.; Flôres, S.H. Dietary fiber from orange byproducts as a potential fat replacer. LWT Food Sci. Technol. 2013, 53, 9-14.

7. Karam, M.C.; Petit, J.; Zimmer, D.; Baudelaire Djantou, E.; Scher, J. Effects of drying and grinding in production of fruit and vegetable powders: A review. J. Food Eng. 2016, 188, 32-49.

8. Majerska, J.; Michalska, A.; Figiel, A. A review of new directions in managing fruit and vegetable processing by-products. Trends Food Sci. Technol. 2019, 88, 207-219.

9. AOAC, 2000. Official method 973.18, 2000. Official methods of analysis of the Association of Official Analytical Chemists, 18th edition.Association of Official Analytical Chemist, Arlington, VA, EEUU.

10. Mertens, D.; Allen, M.; Carmany, J.; Clegg, J.; Davidowicz, A.; Drouches, M.; Frank, K.; Gambin, D.; Garkie, M.; Gildemeister, B.; et al. Gravimetric Determination of AmylaseTreated Neutral Detergent Fiber in Feeds with Refluxing in Beakers or Crucibles: Collaborative Study. J. AOAC Int. 2002, 85, 1217-1240. 
11. Mimouni, A.; Deeth, H.C.; Whittaker, A.K.; Gidley, M.J.; Bhandari, B.R. Rehydration process of milk protein concentrate powder monitored by static light scattering. Food Hydrocoll. 2009, 23, 1958-1965.

12. Cai, Y.Z.; Corke, H. Production and properties of spray-dried Amaranthus betacyanin pigments. J. Food Sci. 2000, 65, 1248-1252. doi:10.1111/j.1365-2621.2000.tb10273.x.

13. Freudig, B.; Hogekamp, S.; Schubert, H. Dispersion of powders in liquids in a stirred vessel. Chem. Eng. Process. Process. Intensif. 1999, 38, 525-532.

14. Raghavendra, S.N.; Rastogi, N.K.; Raghavarao, K.S.M.S.; Tharanathan, R.N. Dietary fiber from coconut residue: Effects of different treatments and particle size on the hydration properties. Eur. Food Res. Technol. 2004, 218, 563-567.

15. Robertson, J.A.; de Monredon, F.D.; Dysseler, P.; Guillon, F.; Amado, R.; Thibault, J.-F. Hydration Properties of Dietary Fibre and Resistant Starch: A European Collaborative Study. LWT Food Sci. Technol. 2000, 33, 72-79.

16. Garau, M.C.; Simal, S.; Rosselló, C.; Femenia, A. Effect of air-drying temperature on physico-chemical properties of dietary fibre and antioxidant capacity of orange (Citrus aurantium v. Canoneta) by-products. Food Chem. 2007, 104, 1014-1024.

17. Yasumatsu, K.; Sawada, K.; Moritaka, S.; Misaki, M.; Toda, J.; Wada, T.; Ishii, K. Whipping and Emulsifying Properties of Soybean Products. Agric. Biol. Chem. 1972, 36, 719-727.

18. Singleton, V.L.; Orthofer, R.; Lamuela-Raventós, R.M. [14] Analysis of total phenols and other oxidation substrates and antioxidants by means of folin-ciocalteu reagent. Methods Enzymol. 1999, 299, 152-178.

19. Wolfe, K.; Wu, X.; Liu, R.H. Antioxidant activity of apple peels. J. Agric. Food Chem. 2003, 51, 609-614.

20. Luximon-Ramma, A.; Bahorun, T.; Crozier, A.; Zbarsky, V.; Datla, K.P.; Dexter, D.T.; Aruoma, O.I. Characterization of the antioxidant functions of flavonoids and proanthocyanidins in Mauritian black teas. Food Res. Int. 2005, 38, 357-367.

21. Kuskoski, E.M.; Asuero, A.G.; Troncoso, A.M.; Mancini-Filho, J.; Fett, R. Aplicación de diversos métodos químicos para determinar actividad antioxidante en pulpa de frutos. Food Sci. Technol. 2005, 25, 726-732.

22. Stratil, P.; Klejdus, B.; Kubáň, V. Determination of total content of phenolic compounds and their antioxidant activity in vegetables-Evaluation of spectrophotometric methods. J. Agric. Food Chem. 2006, 54, 607-616.

23. Re, R.; Pellegrini, N.; Proteggente, A.; Pannala, A.; Yang, M.; Rice-Evans, C. Antioxidant activity applying an improved ABTS radical cation decolorization assay. Free Radic. Biol. Med. 1999, 26, 1231-1237.

24. Rodrigues, E.; Mariutti, L.R.B.; Mercadante, A.Z. Carotenoids and phenolic compounds from Solanum sessiliflorum, an unexploited amazonian fruit, and their scavenging capacities against reactive oxygen and nitrogen species. J. Agric. Food Chem. 2013, 61, 3022-3029.

25. Bunea, A.; Andjelkovic, M.; Socaciu, C.; Bobis, O.; Neacsu, M.; Verhé, R.; Camp, J. Van Total and individual carotenoids and phenolic acids content in fresh, refrigerated and processed spinach (Spinacia oleracea L.). Food Chem. 2008, 108, 649-656. 
26. Wolf, W.; Spiess, W.E.L.; Jung, G. Standardization of Isotherm Measurements (Cost Project 90 and 90 bis). In Properties of Water in Foods; En Simatos, D., Multon, J.L., Eds.; Springer, Dordrecht, The Netherlands, 1985; pp. 661-679.

27. Brunauer, S.; Deming, L.S.; Deming, W.E.; Teller, E. On a Theory of the van der Waals Adsorption of Gases. J. Am. Chem. Soc. 1940, 62, 1723-1732.

28. Martínez-Las Heras, R.; Heredia, A.; Castelló, M.L.; Andrés, A. Moisture sorption isotherms and isosteric heat of sorption of dry persimmon leaves. Food Biosci. 2014, 7, 88-94

29. Brunauer, S.; Emmett, P.H.; Teller, E. Adsorption of Gases in Multimolecular Layers. J. Am. Chem. Soc. 1938, 60, 309-319.

30. Vesterlund, S.; Salminen, K.; Salminen, S. Water activity in dry foods containing live probiotic bacteria should be carefully considered: A case study with Lactobacillus rhamnosus GG in flaxseed. Int. J. Food Microbiol. 2012, 157, 319-321.

31. Viuda-Martos, M.; Ruiz-Navajas, Y.; Martin-Sánchez, A.; Sánchez-Zapata, E.; Fernández-López, J.; Sendra, E.; Sayas-Barberá, E.; Navarro, C.; Pérez-Álvarez, J.A. Chemical, physico-chemical and functional properties of pomegranate (Punica granatum L.) bagasses powder co-product. J. Food Eng. 2012, 110, 220-224.

32. Llobera, A.; Cañellas, J. Dietary fibre content and antioxidant activity of Manto Negro red grape (Vitis vinifera): Pomace and stem. Food Chem. 2007, 101, 659-666..

33. Sudha, M.L.; Baskaran, V.; Leelavathi, K. Apple pomace as a source of dietary fiber and polyphenols and its effect on the rheological characteristics and cake making. Food Chem. 2007, 104, 686-692.

34. Happi Emaga, T.; Robert, C.; Ronkart, S.N.; Wathelet, B.; Paquot, M. Dietary fibre components and pectin chemical features of peels during ripening in banana and plantain varieties. Bioresour. Technol. 2008, 99, 4346-4354.

35. Figuerola, F.; Hurtado, M.L.; Estévez, A.M.; Chiffelle, I.; Asenjo, F. Fibre concentrates from apple pomace and citrus peel as potential fibre sources for food enrichment. Food Chem. 2005, 91, 395-401.

36. Amaya-Cruz, D.M.; Rodríguez-González, S.; Pérez-Ramírez, I.F.; Loarca-Piña, G.; Amaya-Llano, S.; Gallegos-Corona, M.A.; Reynoso-Camacho, R. Juice by-Products as a source of dietary fibre and antioxidants and their effect on hepatic steatosis. J. Funct. Foods 2015, 17, 93-102.

37. Larrauri, J. New approaches in the preparation of high dietary fibre powders from fruit by-products. Trends Food Sci. Technol. 1999, 10, 3-8.

38. Agostoni, C.; Bresson, J.-L.; Fairweather-Tait, S.; Flynn, A.; Golly, I.; Korhonen, H.; Lagiou, P.; Løvik, M.; Marchelli, R.; Martin, A.; et al. Scientific Opinion on Dietary Reference Values for carbohydrates and dietary fibre. EFSA J. 2016, 8, 1462.

39. Pérez-Álvarez, J.A.; Viuda-Martos, M.; López-Marcos, M.C.; Fernández-López, J.; Sendra, E.; López-Vargas, J.H. Role of Fiber in Cardiovascular Diseases: A Reviewle. Compr. Rev. Food Sci. Food Saf. 2010, 9, 240-258.

40. Lucas-González, R.; Viuda-Martos, M.; Pérez-Álvarez, J.Á.; Fernández-López, J. Evaluation of Particle Size Influence on Proximate Composition, Physicochemical, Techno-Functional and Physio-Functional Properties of Flours Obtained from Persimmon (Diospyros kaki Trumb.) Coproducts. Plant Foods Hum. Nutr. 2017, 72, 6773. 
41. Park, H.-J.; Lee, Y.; Eun, J.-B. Physicochemical characteristics of kimchi powder manufactured by hot air drying and freeze drying. Biocatal. Agric. Biotechnol. 2016, 5, 193-198.

42. Santos de Sousa, A.; Vilela Borges, S.; Ferreira Magalhães, N.; Vaz Ricardo, H.; Damico Azevedo, A. Spray-Dried Tomato Powder: Reconstitution Properties and Colour. Braz. Arch. Biol. Technol. 2008, 51, 607-614.

43. Bakar, J.; Ee, S.C.; Muhammad, K.; Hashim, D.M.; Adzahan, N. Spray-Drying Optimization for Red Pitaya Peel (Hylocereus polyrhizus). Food Bioprocess Technol. 2013, 6, 1332-1342.

44. Bhusari, S.N.; Muzaffar, K.; Kumar, P. Effect of carrier agents on physical and microstructural properties of spray dried tamarind pulp powder. Powder Technol. 2014, 266, 354-364.

45. Ahmed, A.M.; Ishida, Y.; Shimamoto, T. Molecular characterization of antimicrobial resistance in Salmonella isolated from animals in Japan. J. Appl. Microbiol. 2009, 106, 402-409.

46. Lecumberri, E.; Mateos, R.; Izquierdo-Pulido, M.; Rupérez, P.; Goya, L.; Bravo, L. Dietary fibre composition, antioxidant capacity and physico-chemical properties of a fibre-rich product from cocoa (Theobroma cacao L.). Food Chem. 2007, 104, 948-954.

47. Serna-Cock, L.; Torres-León, C.; Ayala-Aponte, A. Evaluación de polvos alimentarios obtenidos de cáscaras de mango (Mangifera indica) como fuente de ingredientes funcionales. Inf. Tecnol. 2015, 26, 41-50..

48. Karnik, D.; Wicker, L. Emulsion stability of sugar beet pectin fractions obtained by isopropanol fractionation. Food Hydrocoll. 2018, 74, 249-254.

49. Tao, Y.; Wu, Y.; Yang, J.; Jiang, N.; Wang, Q.; Chu, D.-T.; Han, Y.; Zhou, J. Thermodynamic sorption properties, water plasticizing effect and particle characteristics of blueberry powders produced from juices, fruits and pomaces. Powder Technol. 2018, 323, 208-218.

50. Martínez-Las Heras, R.; Landines, E.F.; Heredia, A.; Castelló, M.L.; Andrés, A. Influence of drying process and particle size of persimmon fibre on its physicochemical, antioxidant, hydration and emulsifying properties. J. Food Sci. Technol. 2017, 54,

51. Mphahlele, R.R.; Fawole, O.A.; Makunga, N.P.; Opara, U.L. Effect of drying on the bioactive compounds, antioxidant, antibacterial and antityrosinase activities of pomegranate peel. BMC Complement. Altern. Med. 2016, 16, 143.

52. Crozier, S.J.; Preston, A.G.; Hurst, J.W.; Payne, M.J.; Mann, J.; Hainly, L.; Miller, D.L. Cacao seeds are a "Super Fruit": A comparative analysis of various fruit powders and products. Chem. Cent. J. 2011, 5, 5.

53. Michalska, A.; Wojdyło, A.; Lech, K.; Łysiak, G.P.; Figiel, A. Effect of different drying techniques on physical properties, total polyphenols and antioxidant capacity of blackcurrant pomace powders. LWT Food Sci. Technol. 2017, 78, 114-121.

54. Dorta, E.; Lobo, M.G.; Gonzalez, M. Reutilization of mango byproducts: Study of the effect of extraction solvent and temperature on their antioxidant properties. J. Food Sci. 2012, 77, 80-88.

55. Rana, S.; Gupta, S.; Rana, A.; Bhushan, S. Functional properties, phenolic constituents and antioxidant potential of industrial apple pomace for utilization as active food ingredient. Food Sci. Hum. Wellness 2015, 4, 180-187. 
56. Ozgen, M.; Reese, R.N.; Tulio, A.Z.; Scheerens, J.C.; Miller, A.R. Modified 2,2-azino-bis3-ethylbenzothiazoline-6-sulfonic acid (ABTS) method to measure antioxidant capacity of selected small fruits and comparison to ferric reducing antioxidant power (FRAP) and 2,2'-diphenyl-1-picrylhydrazyl (DPPH) methods. J. Agric. Food Chem. 2006, 54, 1151-1157.

57. Del Caro, A.; Piga, A.; Vacca, V.; Agabbio, M. Changes of flavonoids, vitamin C and antioxidant capacity in minimally processed citrus segments and juices during storage. Food Chem. 2004, 84, 99-105.

58. Da Silva, L.M.R.; De Figueiredo, E.A.T.; Ricardo, N.M.P.S.; Vieira, I.G.P.; De Figueiredo, R.W.; Brasil, I.M.; Gomes, C.L. Quantification of bioactive compounds in pulps and byproducts of tropical fruits from Brazil. Food Chem. 2014, 143, 398-404.

59. Albanese, D.; Adiletta, G.; D'Acunto, M.; Cinquanta, L.; Di Matteo, M. Tomato peel drying and carotenoids stability of the extracts. Int. J. Food Sci. Technol. 2014, 49, 2458-2463.

60. Bub, A.; Watzl, B.; Abrahamse, L.; Delincée, H.; Adam, S.; Wever, J.; Müller, H.; Rechkemmer, G. Moderate Intervention with Carotenoid-Rich Vegetable Products Reduces Lipid Peroxidation in Men. J. Nutr. 2000, 130, 2200-2206. 


\section{Conclusiones del capítulo 3.3}

El bagazo de lulo resultó ser una materia prima adecuada para la obtención de un polvo rico en fibra y carotenoides. Este polvo podría ser muy útil como ingrediente en la industria alimentaria o a nivel doméstico para enriquecer diferentes tipos de alimentos o recetas con estos compuestos. El desequilibrio entre fibra soluble e insoluble debe tenerse en cuenta en el estudio de las posibles aplicaciones.

El procesado del bagazo combinando la operación de triturado con un secado por aire caliente a temperatura moderada, ha permitido obtener polvos estables con una actividad de agua inferior a 0,3 , lo que asegura su estabilidad durante el almacenamiento. Las propiedades de interacción con el agua como la solubilidad, la humectabilidad y la capacidad de hinchamiento presentaron valores adecuados, mientras que las propiedades emulsionantes no resultaron importantes. 


\section{CONCLUSIONES GENERALES}




\section{CONCLUSIONES GENERALES}

1. La malnutrición, provocada tanto por el déficit de nutrientes como por el exceso de estos, es una realidad en Colombia, y más concretamente en el departamento del Chocó en el que se enmarca la presente tesis doctoral. A pesar de la elevada biodiversidad y disponibilidad de frutas autóctonas ricas en nutrientes, un alto porcentaje de niños con edad comprendida entre 2 y 5 años presentan deficiencias en el consumo de fibra, vitaminas $A$ y $C$, calcio y hierro, que repercuten en su desarrollo.

2. El fruto del lulo, cuyo cultivo ha sido priorizado por el gobierno colombiano para el desarrollo tecnológico y de innovación, presenta características estructurales, físico-químicas y funcionales muy favorables para un aprovechamiento integral en el desarrollo de alimentos saludables, de elevado valor nutritivo y con componentes específicos para la prevención de enfermedades no transmisibles. La IV, las $\mathrm{HPH}$, la fermentación y el secado por aire caliente son tecnologías disponibles y accesibles útiles para el desarrollo de estos alimentos.

3. Las características estructurales del fruto del lulo resultaron adecuadas para la incorporación de compuestos fisiológicamente activos y/o probióticos mediante el proceso de impregnación a vacío. Por otra parte, la aplicación de un tratamiento de HPH a 100-150 MPa al zumo, permitió mejorar la estabilidad de este, produciendo, además, un incremento en la diversidad de compuestos polifenólicos y en los niveles de concentración de espermidina. Además, el zumo de lulo rectificado a $\mathrm{pH} \mathrm{5,5} \mathrm{y} \mathrm{homogeneizado} \mathrm{resultó} \mathrm{ser} \mathrm{una} \mathrm{matriz}$ adecuada para llevar a cabo la fermentación con potenciales probióticos. El Lactobacillus reuteri CECT 925 mostró ser un microorganismo con buena capacidad para resistir a las condiciones de la digestión gastrointestinal in vitro.

4. Las operaciones de deshidratación y molienda aplicadas al bagazo resultante de obtener zumo de lulo permitieron obtener un polvo con un contenido importante de fibra, fenoles totales, flavonoides y carotenoides. En relación con los métodos de deshidratación, la liofilización proporcionó las mejores propiedades antioxidantes y un mayor contenido en carotenoides, resultando un contenido aceptable en el secado con aire caliente a $60^{\circ} \mathrm{C}$. El tipo de secado también 
influyó en las propiedades fisicoquímicas y de interacción con el agua, que determinan las principales aplicaciones a nivel industrial.

5. Como conclusión general podemos decir, que la presente tesis doctoral aporta, para Colombia y en especial para el departamento del Chocó, conocimiento científico básico para el desarrollo de nuevos productos que contribuyan a mejorar la situación de malnutrición de la población infantil y adulta, a partir de recursos autóctonos. No hay duda de que las frutas tropicales y los zumos de estas tienen un gran interés para los consumidores y la industria alimentaria y, también, para la investigación y el desarrollo en las universidades. En concreto, el fruto del lulo es una fuente importante de compuestos bioactivos con efecto demostrado en la prevención de enfermedades, y su zumo resulta, además, un vehículo adecuado para la incorporación de probióticos. Además, más allá del valor nutricional del zumo, el procesado del subproducto o bagazo resultante de la obtención del mismo representa una opción valiosa para recuperar compuestos bioactivos y/o obtener nuevos ingredientes funcionales de manera sostenible. 


\section{CONSIDERACIONES FINALES}




\section{CONSIDERACIONES FINALES}

Leidy Indira Hinestroza Córdoba, autora de la presente tesis doctoral, docente de tiempo completo en la Universidad Tecnológica del Chocó (UTCH) y se incorporará a dicha entidad en enero del 2022. Durante los últimos tres años ha disfrutado de una beca crédito condenable en el marco del "Fortalecimiento de los encadenamiento productivos de las Subregiones del Chocó" financiado por el Fondo de Ciencia Tecnología e Innovación CTel, del Sistema General de Regalías de Colombia, con Recursos del Departamento del Chocó, que le ha permitido estar como alumna de doctorado de la Universitat Politècnica de València (UPV), formar parte del grupo de investigación en alimentos funcionales del Instituto de Ingeniería de Alimentos para el Desarrollo (IIAD) en la UPV y establecer la colaboración entre la UPV y la UTCH llevando a cabo la investigación científica que constituye la presente tesis doctoral.

La transferencia de estos conocimientos a la sociedad colombiana requiere, como paso siguiente, de una investigación aplicada de desarrollo, adaptación y cooperación que tenga en cuenta las condiciones reales en el departamento del Chocó (Colombia). Los resultados obtenidos ya se han utilizado como antecedentes y justificación de un proyecto de cooperación que el grupo de investigación en alimentos funcionales del IIAD ha solicitado a la UPV en el contexto de la convocatoria ADSIDEO 2021. Los objetivos del proyecto se adaptan a la situación local y plantean propuestas que pueden transformarse de una forma relativamente rápida y sencilla en ideas de negocios locales, ya que: Se basan en el aprovechamiento de materias primas autóctonas de cultivo priorizado por el gobierno colombiano, plantean la aplicación de tecnologías disponibles, e incluyen acciones de educación y concienciación.

El proyecto de tesis inicial incluía el estudio de las posibilidades de enriquecimiento de las harinas de plátano popocho y primitivo, para la obtención de papillas más nutritivas que ayuden a disminuir las deficiencias nutricionales de la población infantil en el departamento del Chocó. La supervisión de este objetivo estaba prevista que la realizase la Dra. Alicia Rios (DEP). Se realizaron algunos ensayos de caracterización de las harinas, incluyendo composición en macro y micronutrientes y caracterización microestructural, pero el fallecimiento repentino de la Dra. Alicia Rios y la 
pandemia COVID-19 han imposibilitado el cumplimiento de este objetivo. Se espera poder llevar a cabo las actividades dentro de las acciones del proyecto ADSIDEO-2021. 
Anexos

\section{ANEXOS}




\section{ANEXOS}

Table S1. Phytochemical profile of the lulo fruit extract by high resolution LC-MS /MS.

\begin{tabular}{|c|c|c|c|c|c|c|}
\hline \multicolumn{7}{|c|}{ Lulo fruit } \\
\hline Compound name & $\begin{array}{c}\text { RT } \\
(\mathrm{min})\end{array}$ & $\begin{array}{c}\mathrm{M} / \mathrm{Z} \\
\text { experimental }\end{array}$ & $\begin{array}{c}\text { Teoric } \\
\text { mass }\end{array}$ & MS/MS fragments & $\begin{array}{c}\text { Molecular } \\
\text { Formula }\end{array}$ & Error (ppm) \\
\hline \multicolumn{7}{|l|}{ Hydroxycinnamic acids $[\mathrm{M}-\mathrm{H}]^{-}$} \\
\hline Caffeic acid & 11.13 & 179.035 & 179.035 & $134 / 133 / 88$ & $\mathrm{C}_{9} \mathrm{H}_{8} \mathrm{O}_{4}$ & 0.1 \\
\hline 3-Caffeoylquinic acid & 13.15 & 353.0881 & 353.0878 & $191 / 179$ & $\mathrm{C}^{16} \mathrm{H}_{18} \mathrm{O}_{9}$ & 0.8 \\
\hline 4-Caffeoylquinic acid & 13.15 & 353.0881 & 353.0878 & - & $\mathrm{C}^{16} \mathrm{H}_{18} \mathrm{O}_{9}$ & 0.8 \\
\hline 5-Caffeoylquinic acid & 13.15 & 353.0881 & 353.0878 & 191 & $\mathrm{C}^{16} \mathrm{H}_{18} \mathrm{O}_{9}$ & 0.8 \\
\hline Trans-3-Caffeoylquinic acid & 13.15 & 353.0881 & 353.0878 & - & $\mathrm{C}^{16} \mathrm{H}_{18} \mathrm{O}_{9}$ & 0.8 \\
\hline 1-Caffeoylquinic acid & 13.15 & 353.0881 & 353.0878 & - & $\mathrm{C}^{16} \mathrm{H}_{18} \mathrm{O}_{9}$ & 0.8 \\
\hline Cis-3-Caffeoylquinic acid & 13.15 & 353.0881 & 353.0878 & - & $\mathrm{C}^{16} \mathrm{H}_{18} \mathrm{O}_{9}$ & 0.8 \\
\hline Trans-5-Caffeoylquinic acid & 13.15 & 353.0881 & 353.0878 & $191 / 179$ & $\mathrm{C}^{16} \mathrm{H}_{18} \mathrm{O}_{9}$ & 0.8 \\
\hline Cis-5-Caffeoylquinic acid & 13.15 & 353.0881 & 353.0878 & $191 / 179$ & $\mathrm{C}^{16} \mathrm{H}_{18} \mathrm{O}_{9}$ & 0.8 \\
\hline Ferulic acid 4-O-glucoside & 13.91 & 355.1038 & 355.1035 & $131 / 159 / 174$ & $\mathrm{C}^{16} \mathrm{H}_{18} \mathrm{O}_{9}$ & 1 \\
\hline Feruloyl glucose & 13.91 & 355.1038 & 355.1035 & $131 / 159 / 174$ & $\mathrm{C}^{16} \mathrm{H}_{18} \mathrm{O}_{9}$ & 1 \\
\hline Sinapic acid & 13.91 & 223.0613 & 223.0612 & $92 / 120$ & $\mathrm{C}_{11} \mathrm{H}_{12} \mathrm{O}_{5}$ & 0.6 \\
\hline Sinapoyl glucose & 13.92 & 385.1144 & 385.114 & $174 / 189$ & $\mathrm{C}_{1} 7 \mathrm{H}_{22} \mathrm{O}_{10}$ & 0.9 \\
\hline Sitostanyl ferulate & 20.8 & 607.4377 & 607.4368 & 265 & $\mathrm{C}_{39} \mathrm{H}_{60} \mathrm{O}_{5}$ & 1.5 \\
\hline \multicolumn{7}{|l|}{ Flavonoids $[\mathrm{M}-\mathrm{H}]$} \\
\hline Quercetin 3,4-O-diglucoside & 15.74 & 625.1432 & 625.141 & $270 / 299$ & $\mathrm{C}_{27} \mathrm{H}_{30} \mathrm{O}_{17}$ & 3.5 \\
\hline Quercetin 3-O-glucosyl-glucoside & 15.74 & 625.1432 & 625.141 & $270 / 299$ & $\mathrm{C}_{27} \mathrm{H}_{30} \mathrm{O}_{17}$ & 3.5 \\
\hline Quercetin 3-O-sophoroside & 15.74 & 625.1432 & 625.141 & 299 & $\mathrm{C}_{27} \mathrm{H}_{30} \mathrm{O}_{17}$ & 3.5 \\
\hline Myricetin 3-O-rutinoside & 15.74 & 625.1432 & 625.141 & $299 / 301$ & $\mathrm{C}_{27} \mathrm{H}_{30} \mathrm{O}_{17}$ & 3.5 \\
\hline Kaempferol 3,7-0-diglucoside & 16.11 & 609.1491 & 609.1461 & $270 / 299$ & $\mathrm{C}_{27} \mathrm{H}_{30} \mathrm{O}_{16}$ & 4.8 \\
\hline Kaempferol 3-O-sophoroside & 16.11 & 609.1491 & 609.1461 & 299 & $\mathrm{C}_{27} \mathrm{H}_{30} \mathrm{O}_{16}$ & 4.8 \\
\hline Quercetin 3-O-rhamnosyl-galactoside & 16.11 & 609.1491 & 609.1461 & 299 & $\mathrm{C}_{27} \mathrm{H}_{30} \mathrm{O}_{16}$ & 4.8 \\
\hline
\end{tabular}




\begin{tabular}{|c|c|c|c|c|c|c|}
\hline \multirow[b]{2}{*}{ Compound name } & \multirow{2}{*}{$\begin{array}{c}\text { RT } \\
(\min )\end{array}$} & \multirow{2}{*}{$\begin{array}{c}\mathrm{M} / \mathrm{Z} \\
\text { Experimental }\end{array}$} & \multirow{2}{*}{$\begin{array}{l}\text { Teoric } \\
\text { mass }\end{array}$} & \multirow[b]{2}{*}{ MS/MS fragments } & \multicolumn{2}{|l|}{ Molecular } \\
\hline & & & & & Formula & Error (ppm) \\
\hline $\begin{array}{l}\text { Quercetin 3-O-galactoside 7-O- } \\
\text { rhamnoside }\end{array}$ & 16.11 & 609.1491 & 609.1461 & 229 & $\mathrm{C}_{27} \mathrm{H}_{30} \mathrm{O}_{16}$ & 4.8 \\
\hline Quercetin 3-O-rutinoside & 16.11 & 609.1491 & 609.1461 & 299 & $\mathrm{C}_{27} \mathrm{H}_{30} \mathrm{O}_{16}$ & 4.8 \\
\hline $\begin{array}{l}\text { Kaempferol 3-O-galactoside 7-O- } \\
\text { rhamnoside }\end{array}$ & 16.66 & 593.1536 & 593.1512 & 285 & $\mathrm{C}_{27} \mathrm{H}_{30} \mathrm{O}_{15}$ & 4.1 \\
\hline Kaempferol 3-O-rutinoside & 16.66 & 593.1536 & 593.1512 & 285 & $\mathrm{C}_{27} \mathrm{H}_{30} \mathrm{O}_{15}$ & 4.1 \\
\hline $\begin{array}{l}\text { Isorhamnetin 3-O-glucoside 7-O- } \\
\text { rhamnoside }\end{array}$ & 16.63 & 623.1639 & 623.1618 & $298 / 313$ & $\mathrm{C}_{28} \mathrm{H}_{32} \mathrm{O}_{16}$ & 3.4 \\
\hline Isorhamnetin 3-O-rutinoside & 16.63 & 623.1639 & 623.1618 & $298 / 313$ & $\mathrm{C}_{28} \mathrm{H}_{32} \mathrm{O}_{16}$ & 3.4 \\
\hline Kaempferol 3-O-acetyl-glucoside & 17.86 & 489.1053 & 489.1039 & $254 / 283$ & $\mathrm{C}_{23} \mathrm{H}_{22} \mathrm{O}_{12}$ & 3.1 \\
\hline Kaempferol 3-O-galactoside & 17.65 & 447.0939 & 447.0933 & $226 / 254 / 283$ & $\mathrm{C}_{21} \mathrm{H}_{20} \mathrm{O}_{11}$ & 1.3 \\
\hline Kaempferol 3-O-glucoside & 17.65 & 447.0939 & 447.0933 & $226 / 254 / 283$ & $\mathrm{C}_{21} \mathrm{H}_{20} \mathrm{O}_{11}$ & 1.3 \\
\hline Kaempferol 7-O-glucoside & 17.65 & 447.0933 & 447.0939 & $226 / 254 / 283$ & $\mathrm{C}_{21} \mathrm{H}_{20} \mathrm{O}_{11}$ & 1.3 \\
\hline Quercetin 3-O-rhamnoside & 17.65 & 447.0939 & 447.0933 & $226 / 254 / 283$ & $\mathrm{C}_{21} \mathrm{H}_{20} \mathrm{O}_{11}$ & 1.3 \\
\hline Isorhamnetin 3-O-glucoside & 17.67 & 477.1049 & 477.1039 & $242 / 270 / 284 / 313$ & $\mathrm{C}_{22} \mathrm{H}_{22} \mathrm{O}_{12}$ & 2.2 \\
\hline Isorhamnetin 4-0-glucoside & 17.67 & 477.1049 & 477.1039 & $242 / 270 / 284 / 313$ & $\mathrm{C}_{22} \mathrm{H}_{22} \mathrm{O}_{12}$ & 2.2 \\
\hline Isorhamnetin 3-O-galactoside & 17.67 & 477.1049 & 477.1039 & $242 / 270 / 284 / 313$ & $\mathrm{C}_{22} \mathrm{H}_{22} \mathrm{O}_{12}$ & 2.2 \\
\hline Kaempferide & 20.34 & 299.0563 & 299.0561 & $88 / 118 / 134 / 184 / 186$ & $\mathrm{C}_{16} \mathrm{H}_{12} \mathrm{O}_{6}$ & 0.6 \\
\hline Phenolic acids $[\mathrm{M}-\mathrm{H}]^{-}$ & & & & & & \\
\hline Benzoic acid & 14.57 & 121.0294 & 121.0295 & - & $\mathrm{C}_{7} \mathrm{H}_{6} \mathrm{O}_{2}$ & -0.7 \\
\hline Other phenolics $[\mathrm{M}-\mathrm{H}]^{-}$ & & & & & & \\
\hline 4-Hydroxybenzaldehyde & 14.57 & 121.0294 & 121.0295 & - & $\mathrm{C}_{7} \mathrm{H}_{6} \mathrm{O}_{2}$ & -0.7 \\
\hline Chrysoeriol 7-0-apiosyl-glucoside & 16.66 & 593.1536 & 593.1512 & $254 / 284$ & $\mathrm{C}_{27} \mathrm{H}_{30} \mathrm{O}_{15}$ & 4.1 \\
\hline 6-Hydroxyluteolin 7-O-rhamnoside & 17.65 & 447.0939 & 447.0933 & $226 / 254 / 283$ & $\mathrm{C}_{21} \mathrm{H}_{20} \mathrm{O}_{11}$ & 1.3 \\
\hline 4-Vinylphenol & 18.81 & 119.0503 & 119.0502 & $87 / 88 / 92$ & $\mathrm{C}_{8} \mathrm{H}_{8} \mathrm{O}$ & 0.7 \\
\hline Eriodictyol & 18.3 & 287.0568 & 287.0561 & 134 & $\mathrm{C}_{15} \mathrm{H}_{12} \mathrm{O}_{6}$ & 2.3 \\
\hline Chrysoeriol & 20.34 & 299.0563 & 299.0561 & $88 / 118 / 184 / 186$ & $\mathrm{C}_{16} \mathrm{H}_{12} \mathrm{O}_{6}$ & 0.6 \\
\hline Diosmetin & 20.34 & 299.0563 & 299.0561 & $88 / 118 / 184 / 186$ & $\mathrm{C}_{16} \mathrm{H}_{12} \mathrm{O}_{6}$ & 0.6 \\
\hline
\end{tabular}


Table S2. Phytochemical profile of non- homogenized lulo juice by high resolution LC-MS/MS

\begin{tabular}{|c|c|c|c|c|c|c|}
\hline \multicolumn{7}{|c|}{ Non-homogenized } \\
\hline Compound name & $\begin{array}{l}\text { RT } \\
(\min )\end{array}$ & $\begin{array}{l}\mathrm{M} / \mathrm{Z} \\
\text { experimental }\end{array}$ & $\begin{array}{l}\text { Teoric } \\
\text { mass }\end{array}$ & MS/MS fragments & $\begin{array}{l}\text { Molecular } \\
\text { Formula }\end{array}$ & $\begin{array}{l}\text { Error } \\
\text { (ppm) }\end{array}$ \\
\hline \multicolumn{7}{|c|}{ Hydroxycinnamic acids $[\mathrm{M}-\mathrm{H}]^{-}$} \\
\hline Caffeic acid & 11.13 & 179.035 & 179.035 & $134 / 133 / 88$ & $\mathrm{C}_{9} \mathrm{H}_{8} \mathrm{O}_{4}$ & 0.1 \\
\hline Cis-Caffeic acid & 13.66 & 179.035 & 179.035 & $134 / 133 / 88$ & $\mathrm{C}_{9} \mathrm{H}_{8} \mathrm{O}_{4}$ & 0.1 \\
\hline 4-Caffeoylquinic acid & 13.29 & 353.0886 & 353.0878 & $190 / 84$ & $\mathrm{C}_{16} \mathrm{H}_{18} \mathrm{O}_{9}$ & 2.4 \\
\hline 1-Caffeoylquinic acid & 13.29 & 353.0878 & 353.0886 & 190 & $\mathrm{C}_{16} \mathrm{H}_{18} \mathrm{O}_{9}$ & 2.4 \\
\hline Cis-3-Caffeoylquinic acid & 13.29 & 353.0886 & 353.0878 & $190 / 84$ & $\mathrm{C}_{16} \mathrm{H}_{18} \mathrm{O}^{9}$ & 2.4 \\
\hline Trans-5-Caffeoylquinic acid & 13.29 & 353.0886 & 353.0878 & $190 / 84$ & $\mathrm{C}_{16} \mathrm{H}_{18} \mathrm{O}_{9}$ & 2.4 \\
\hline 5-Feruloylquinic .acid & 15.43 & 367.1035 & 367.104 & $190 / 133 / 92$ & $\mathrm{C}_{17} \mathrm{H}_{20} \mathrm{O}_{9}$ & 1.4 \\
\hline 3-Feruloylquinic acid & 15.43 & 367.1035 & 367.104 & $190 / 133 / 92$ & $\mathrm{C}_{17} \mathrm{H}_{20} \mathrm{O}_{9}$ & 1.4 \\
\hline 4-Feruloylquinic acid & 15.43 & 367.1040 & 367.1035 & $190 / 133 / 92$ & $\mathrm{C}_{17} \mathrm{H}_{20} \mathrm{O}_{9}$ & 1.4 \\
\hline Feruloyl glucose & 13.93 & 355.1037 & 355.1035 & $174 / 159 / 131$ & $\mathrm{C}_{16} \mathrm{H}_{20} \mathrm{O}_{9}$ & 0.8 \\
\hline p-Coumaroylquinic acid & 15.06 & 337.0932 & 337.0929 & $190 / 172 / 118 / 92$ & $\mathrm{C}_{16} \mathrm{H}_{18} \mathrm{O}_{8}$ & 0.6 \\
\hline 3-p-Coumaroylquinic acid & 15.06 & 337.0932 & 337.0929 & $190 / 172 / 118 / 92$ & $\mathrm{C}_{16} \mathrm{H}_{18} \mathrm{O}_{8}$ & 1 \\
\hline 4-p-Coumaroylquinic acid & 15.06 & 337.0932 & 337.0929 & $190 / 172 / 118 / 92$ & $\mathrm{C}_{16} \mathrm{H}_{18} \mathrm{O}_{8}$ & 1 \\
\hline 5-p-Coumaroylquinic acid & 15.06 & 337.0932 & 337.0929 & $190 / 172 / 118 / 92$ & $\mathrm{C}_{16} \mathrm{H}_{18} \mathrm{O}_{8}$ & 1 \\
\hline \multicolumn{7}{|l|}{ Phenolic acids [M - H] ${ }^{-}$} \\
\hline
\end{tabular}


Table $\times$ (continued)

\begin{tabular}{|c|c|c|c|c|c|c|}
\hline \multirow[b]{2}{*}{ Other phenolics $[\mathrm{M}-\mathrm{H}]^{-}$} & \multirow[t]{2}{*}{$\begin{array}{c}\text { RT } \\
(\min )\end{array}$} & \multirow[t]{2}{*}{$\begin{array}{c}M / Z \\
\text { experimental }\end{array}$} & \multirow[t]{2}{*}{$\begin{array}{l}\text { Teoric } \\
\text { mass }\end{array}$} & \multirow[t]{2}{*}{$\begin{array}{c}\text { MS/MS } \\
\text { fragments }\end{array}$} & \multicolumn{2}{|c|}{ Error (ppm) } \\
\hline & & & & & & \\
\hline Protocatechuic aldehyde & 11.73 & 137.0244 & 137.0244 & - & $\mathrm{C}_{7} \mathrm{H}_{6} \mathrm{O}_{3}$ & 0.1 \\
\hline Sesamol & 11.73 & 137.0244 & 137.0244 & - & $\mathrm{C}_{7} \mathrm{H}_{6} \mathrm{O}_{3}$ & 0.1 \\
\hline 4-Hydroxycoumarin & 13.23 & 161.0244 & 161.0245 & $143 / 131 / 103 / 88$ & $\mathrm{C}_{9} \mathrm{H}_{6} \mathrm{O}_{3}$ & 0.8 \\
\hline Umbelliferone & 13.23 & 161.0244 & 161.0245 & $143 / 131 / 103 / 88$ & $\mathrm{C}_{9} \mathrm{H}_{6} \mathrm{O}_{3}$ & 0.1 \\
\hline \multicolumn{7}{|l|}{ 3,4-Dihydroxyphenyl-2- } \\
\hline oxypropanoic acid & 13.66 & 179.035 & 179.035 & $134 / 133 / 88$ & $\mathrm{C}_{33} \mathrm{H}_{42} \mathrm{O}_{19}$ & 3.4 \\
\hline 4-Hydroxybenzaldehyde & 14.67 & 121.0295 & 121.0296 & - & $\mathrm{C}_{7} \mathrm{H}_{6} \mathrm{O}_{2}$ & 0.9 \\
\hline 1-Sinapoyl-2-feruloylgentiobiose & 16.12 & 723.2142 & 723.2177 & $542 / 366 / 190$ & $\mathrm{C}_{33} \mathrm{H}_{40} \mathrm{O}_{18}$ & 4.8 \\
\hline Chalconaringenin & 18.8 & 271.0612 & 271.0619 & $82 / 116 / 118$ & $\mathrm{C}_{15} \mathrm{H}_{12} \mathrm{O}_{5}$ & 2.6 \\
\hline Coumarin & 13.32 & 145.0295 & 145.0295 & $106 / 98 / 88$ & $\mathrm{C}_{9} \mathrm{H}_{6} \mathrm{O}_{2}$ & 0.2 \\
\hline p-Coumaric acid 4-O-glucoside & 13.31 & 325.0941 & 325.0929 & $144 / / 116 / 118$ & $\mathrm{C}_{15} \mathrm{H}_{18} \mathrm{O}_{8}$ & 3.7 \\
\hline p-Coumaroyl glucose & 13.31 & 325.0941 & 325.0929 & $144 / 119 / 116$ & $\mathrm{C}_{15} \mathrm{H}_{18} \mathrm{O}_{9}$ & 3.7 \\
\hline \multicolumn{7}{|l|}{ Flavanones [M - H] ${ }^{-}$} \\
\hline Narirutin 4-O-glucoside & 14.21 & 741.2248 & 741.2263 & $208 / 193$ & $\mathrm{C}_{33} \mathrm{H}_{42} \mathrm{O}_{19}$ & 2.1 \\
\hline Pelargonidin 3,5-O-diglucoside & 16.82 & 594.1579 & 594.159 & - & $\mathrm{C}_{27} \mathrm{H}_{31} \mathrm{O}_{15}$ & -1.8 \\
\hline Narirutin & 17.09 & 579.1719 & 579.1743 & $270 / 150$ & $\mathrm{C}_{27} \mathrm{H}_{32} \mathrm{O}_{14}$ & 4.1 \\
\hline Naringin & 17.09 & 579.1719 & 579.1743 & $270 / 150$ & $\mathrm{C}_{27} \mathrm{H}_{32} \mathrm{O}_{14}$ & 4.1 \\
\hline Engeletin & 17.78 & 433.1147 & 433.114 & $270 / 226 / 150 / 118 / 106 / 82$ & $\mathrm{C}_{21} \mathrm{H}_{22} \mathrm{O}_{10}$ & 1.5 \\
\hline Naringenin 7-O-glucoside & 17.78 & 433.1147 & 433.114 & $226 / 150 / 118 / 106 / 82$ & $\mathrm{C} 21 \mathrm{H} 22 \mathrm{O} 10$ & 1.5 \\
\hline Naringenin & 18.8 & 271.0612 & 271.0619 & $118 / 116 / 82$ & $\mathrm{C}_{15} \mathrm{H}_{12} \mathrm{O}_{5}$ & 2.6 \\
\hline Butein & 18.8 & 271.0612 & 271.0619 & $186 / 150 / 118 / 116 / 82$ & $\mathrm{C}_{15} \mathrm{H}_{12} \mathrm{O}_{5}$ & 2.6 \\
\hline \multicolumn{7}{|l|}{ Anthocynins $[\mathrm{M}-\mathrm{H}]^{-}$} \\
\hline Cyanidin 3-O-rutinoside & 16.82 & 594.159 & 594.1579 & - & $\mathrm{C}_{27} \mathrm{H}_{31} \mathrm{O}_{15}$ & -1.8 \\
\hline Pelargonidin 3,5-0-diglucoside & 16.82 & 594.1579 & 594.159 & - & $\mathrm{C}_{27} \mathrm{H}_{31} \mathrm{O}_{15}$ & -1.8 \\
\hline
\end{tabular}


Anexos

Homogenized $50 \mathrm{MPa}$

\begin{tabular}{|c|c|c|c|c|c|c|}
\hline Compound name & $\begin{array}{l}\text { RT } \\
(\min )\end{array}$ & $\begin{array}{l}\mathrm{M} / \mathrm{Z} \\
\text { experimental }\end{array}$ & $\begin{array}{l}\text { Teoric } \\
\text { mass }\end{array}$ & MS/MS fragments & $\begin{array}{l}\text { Molecular } \\
\text { Formula }\end{array}$ & $\begin{array}{l}\text { Error } \\
\text { (ppm) }\end{array}$ \\
\hline \multicolumn{7}{|l|}{ Hydroxycinnamic acids [[M - H] ${ }^{-}$} \\
\hline 3-Caffeoylquinic acid & 12.76 & 353.0878 & 353.0875 & $190 / 84$ & $\mathrm{C}_{16} \mathrm{H}_{18} \mathrm{O}_{9}$ & -0.8 \\
\hline 5-Caffeoylquinic acid & 12.76 & 353.0875 & 353.0878 & $190 / 84$ & $\mathrm{C}_{16} \mathrm{H}_{18} \mathrm{O}_{9}$ & -0.8 \\
\hline 1-Caffeoylquinic acid & 12.76 & 353.0875 & 353.0878 & $190 / 84$ & $\mathrm{C}_{16} \mathrm{H}_{18} \mathrm{O}_{9}$ & -0.8 \\
\hline Cis-3-Caffeoylquinic acid & 12.76 & 353.0875 & 353.0878 & $190 / 84$ & $\mathrm{C}_{16} \mathrm{H}_{18} \mathrm{O}_{9}$ & -0.8 \\
\hline Cis-5-Caffeoylquinic acid & 12.76 & 353.0875 & 353.0878 & $190 / 84$ & $\mathrm{C}_{16} \mathrm{H}_{18} \mathrm{O}_{9}$ & -0.8 \\
\hline Trans-5-Caffeoylquinic acid & 12.76 & 353.0875 & 353.0878 & $190 / 84$ & $\mathrm{C}_{16} \mathrm{H}_{18} \mathrm{O}_{9}$ & -0.8 \\
\hline Trans-3-Caffeoylquinic acid & 12.67 & 353.0875 & 353.0878 & $190 / 84$ & $\mathrm{C}_{16} \mathrm{H}_{18} \mathrm{O}_{9}$ & -0.8 \\
\hline p-Coumaric acid 4-O-glucoside & 12.8 & 325.0929 & 325.0928 & $144 / 118 / 116$ & $\mathrm{C}_{15} \mathrm{H}_{18} \mathrm{O}_{8}$ & -0.2 \\
\hline p-Coumaroyl glucose & 12.95 & 325.093 & 325.0929 & $199 / 144 / 142 / / 116$ & $\mathrm{C}_{15} \mathrm{H}_{18} \mathrm{O}_{8}$ & 0.5 \\
\hline Caffeic acid & 13.13 & 179.0351 & 179.035 & $134 / 133 / 107 / 88$ & $\mathrm{C}_{9} \mathrm{H}_{8} \mathrm{O}_{4}$ & 0.7 \\
\hline Cis-Caffeic acid & 13.13 & 179.0351 & 179.035 & $134 / 133 / 107 / 88$ & $\mathrm{C}_{9} \mathrm{H}_{8} \mathrm{O}_{4}$ & 0.7 \\
\hline Trans-Caffeic acid & 13.13 & 179.0351 & 179.035 & $134 / 133 / 107 / 88$ & $\mathrm{C}_{9} \mathrm{H}_{8} \mathrm{O}_{4}$ & 0.7 \\
\hline Ferulic acid 4-O-glucoside & 13.38 & 355.1035 & 355.103 & $174 / 159 / 131$ & $\mathrm{C}_{16} \mathrm{H}_{20} \mathrm{O}_{9}$ & -1.3 \\
\hline Feruloyl glucose & 13.38 & 355.1035 & 355.103 & $174 / 159 / 131$ & $\mathrm{C}_{16} \mathrm{H}_{20} \mathrm{O}_{9}$ & -1.3 \\
\hline 5-Feruloylquinic acid & 14.84 & 367.1035 & 367.1031 & - & $\mathrm{C}_{17} \mathrm{H}_{20} \mathrm{O}_{9}$ & -0.9 \\
\hline 4-Feruloylquinic acid & 14.84 & 367.1035 & 367.1031 & - & $\mathrm{C}_{17} \mathrm{H}_{20} \mathrm{O}_{9}$ & -0.9 \\
\hline 3-Feruloylquinic acid & 14.84 & 367.1031 & 367.1035 & - & $\mathrm{C}_{17} \mathrm{H}_{20} \mathrm{O}_{9}$ & -0.9 \\
\hline \multicolumn{7}{|l|}{ Flavonoids $[\mathrm{M}-\mathrm{H}]^{-}$} \\
\hline Quercetin 3-O-rhamnosyl-galactoside & 15.8 & 609.1467 & 609.1461 & $299 / 270$ & $\mathrm{C}_{27} \mathrm{H}_{30} \mathrm{O}_{16}$ & 1 \\
\hline Quercetin 3-O-rhamnosyl-galactoside & 15.8 & 609.1467 & 609.1461 & $299 / 270$ & $\mathrm{C}_{27} \mathrm{H}_{30} \mathrm{O}_{16}$ & 1 \\
\hline Kaempferol 3,7-O-diglucoside & 15.8 & 609.1467 & 609.1461 & $299 / 270$ & $\mathrm{C}_{27} \mathrm{H}_{30} \mathrm{O}_{16}$ & 1 \\
\hline Kaempferol 3-O-sophoroside & 15.8 & 609.1461 & 609.1467 & $299 / 270$ & $\mathrm{C}_{27} \mathrm{H}_{30} \mathrm{O}_{16}$ & 1 \\
\hline $\begin{array}{l}\text { Quercetin 3-O-galactoside 7-O- } \\
\text { rhamnoside }\end{array}$ & 15.8 & 609.1467 & 609.1461 & $299 / 270$ & $\mathrm{C}_{27} \mathrm{H}_{30} \mathrm{O}_{16}$ & 1 \\
\hline
\end{tabular}




\begin{tabular}{|c|c|c|c|c|c|c|}
\hline \multicolumn{7}{|l|}{ Table $\times$ (continued) } \\
\hline Compound name & $\begin{array}{c}\text { RT } \\
(\min )\end{array}$ & $\begin{array}{c}\mathrm{M} / \mathrm{Z} \\
\text { experimental }\end{array}$ & $\begin{array}{c}\text { Teoric } \\
\text { mass }\end{array}$ & MS/MS fragments & $\begin{array}{c}\text { Molecular } \\
\text { fornula }\end{array}$ & $\begin{array}{l}\text { Error } \\
\text { (ppm) }\end{array}$ \\
\hline \multicolumn{7}{|l|}{ Isorhamnetin 3-O-glucoside 7-O- } \\
\hline rhamnoside & 16.36 & 623.1618 & 623.162 & $313 / 298 / 270$ & $\mathrm{C}_{28} \mathrm{H}_{32} \mathrm{O}_{16}$ & 0.4 \\
\hline \multicolumn{7}{|l|}{ Kaempferol 3-O-galactoside 7-O- } \\
\hline rhamnoside & 16.4 & 593.1512 & 593.1512 & $283 / 254$ & $\mathrm{C}_{27} \mathrm{H}_{30} \mathrm{O}_{15}$ & 0 \\
\hline Kaempferol 3-O-rutinoside & 16.4 & 593.1512 & 593.1512 & $283 / 254$ & $\mathrm{C}_{27} \mathrm{H}_{30} \mathrm{O}_{15}$ & 0 \\
\hline Kaempferol 3-O-galactoside & 17.3 & 447.0933 & 447.0929 & - & $\mathrm{C}_{21} \mathrm{H}_{20} \mathrm{O}_{11}$ & -0.9 \\
\hline Kaempferol 3-O-glucoside & 17.3 & 447.0933 & 447.0929 & - & $\mathrm{C}_{21} \mathrm{H}_{20} \mathrm{O}_{11}$ & -0.9 \\
\hline Kaempferol 7-O-glucoside & 17.3 & 447.0929 & 447.0933 & - & $\mathrm{C}_{21} \mathrm{H}_{20} \mathrm{O}_{11}$ & -0.9 \\
\hline Quercetin 3-O-rhamnoside & 17.3 & 447.0933 & 447.0929 & - & $\mathrm{C}_{21} \mathrm{H}_{20} \mathrm{O}_{11}$ & -0.9 \\
\hline 3,7-Dimethylquercetin & 18.79 & 329.0666 & 329.0667 & - & $\mathrm{C}_{17} \mathrm{H}_{14} \mathrm{O}_{7}$ & -0.2 \\
\hline \multicolumn{7}{|l|}{ Phenolic acids $[\mathrm{M}-\mathrm{H}]]^{-}$} \\
\hline 2-Hydroxybenzoic acid & 11.25 & 137.0245 & 137.0244 & 107 & $\mathrm{C}_{7} \mathrm{H}_{6} \mathrm{O}_{3}$ & 0.9 \\
\hline 4-Hydroxybenzoic acid & 11.25 & 137.0245 & 137.0244 & 107 & $\mathrm{C}_{7} \mathrm{H}_{6} \mathrm{O}_{3}$ & 0.9 \\
\hline Sesamol & 11.25 & 137.0244 & 137.0245 & 107 & $\mathrm{C}_{7} \mathrm{H}_{6} \mathrm{O}_{3}$ & 0.9 \\
\hline 2-Hydroxybenzoic acid & 11.25 & 137.0245 & 137.0244 & 107 & $\mathrm{C}_{7} \mathrm{H}_{6} \mathrm{O}_{3}$ & 0.9 \\
\hline 4-Hydroxybenzoic acid 4-O-glucoside & 12.67 & 299.0774 & 299.0772 & $92 / 136$ & $\mathrm{C}_{13} \mathrm{H}_{16} \mathrm{O}_{8}$ & 0.5 \\
\hline Benzoic acid & 14.06 & 121.0296 & 121.0295 & 91 & $\mathrm{C}_{7} \mathrm{H}_{6} \mathrm{O}_{2}$ & 0.7 \\
\hline 4-Methoxybenzoic acid & 15.04 & 151.0401 & 151.04 & 90 & $\mathrm{C}_{8} \mathrm{H}_{8} \mathrm{O}_{3}$ & -0.2 \\
\hline \multicolumn{7}{|l|}{ Other phenolics $[\mathrm{M}-\mathrm{H}]{ }^{-}$} \\
\hline Protocatechuic aldehyde & 11.25 & 137.0245 & 137.0244 & 107 & $\mathrm{C}_{7} \mathrm{H}_{6} \mathrm{O}_{3}$ & 0.9 \\
\hline Coumarin & 12.94 & 145.0296 & 145.0295 & $116 / 115 / 87$ & $\mathrm{C}_{9} \mathrm{H}_{6} \mathrm{O}_{2}$ & 0.6 \\
\hline 3,4-Dihydroxyphenyl-2-oxypropanoic acid & 13.13 & 179.035 & 179.0351 & $134 / 108 / 88$ & $\mathrm{C}_{9} \mathrm{H}_{8} \mathrm{O}_{4}$ & 0.7 \\
\hline 4-Hydroxybenzaldehyde & 14.06 & 121.0295 & 121.0296 & 91 & $\mathrm{C}_{7} \mathrm{H}_{6} \mathrm{O}_{2}$ & 0.7 \\
\hline Chrysoeriol 7-0-apiosyl-glucoside & 16.4 & 593.1512 & 593.1512 & $254 / 283$ & $\mathrm{C}_{27} \mathrm{H}_{30} \mathrm{O}_{15}$ & 0 \\
\hline Homovanillyl alcohol & 18.1 & 167.0715 & 167.0714 & - & $\mathrm{C}_{9} \mathrm{H}_{12} \mathrm{O}_{3}$ & 0.8 \\
\hline Jaceosidin & 18.79 & 329.0667 & 329.0666 & - & $\mathrm{C}_{17} \mathrm{H}_{14} \mathrm{O}_{7}$ & 0 \\
\hline
\end{tabular}


Anexos

Table (Contined)

\begin{tabular}{|c|c|c|c|c|c|c|}
\hline Compound name & $\begin{array}{c}\text { RT } \\
(\min )\end{array}$ & $\begin{array}{c}\mathrm{M} / \mathrm{Z} \\
\text { experimental }\end{array}$ & $\begin{array}{c}\text { Teoric } \\
\text { mass }\end{array}$ & MS/MS fragments & $\begin{array}{c}\text { Molecular } \\
\text { fornula }\end{array}$ & $\begin{array}{l}\text { Error } \\
\text { (ppm) }\end{array}$ \\
\hline Narirutin 4-O-glucoside & 16.82 & 301.0716 & 301.0718 & - & $\mathrm{C}_{16} \mathrm{H}_{14} \mathrm{O}_{6}$ & -0.4 \\
\hline Hesperetin & 16.82 & 301.0716 & 301.0718 & - & $\mathrm{C}_{16} \mathrm{H}_{14} \mathrm{O}_{6}$ & -0.4 \\
\hline Hesperidin & 16.8 & 609.1829 & 609.1825 & $300 / 150$ & $\mathrm{C}_{28} \mathrm{H}_{34} \mathrm{O}_{15}$ & 0.7 \\
\hline \multicolumn{7}{|l|}{ Flavones $[\mathrm{M}-\mathrm{H}]^{-}$} \\
\hline Apigenin 6,8-di-C-glucoside & 16.4 & 593.1512 & 593.1512 & $283 / 254$ & $\mathrm{C}_{27} \mathrm{H}_{0} \mathrm{O}_{15}$ & 0 \\
\hline Luteolin 4-O-glucoside & 17.3 & 447.0933 & 447.0929 & - & $\mathrm{C}_{21} \mathrm{H}_{20} \mathrm{O}_{11}$ & -0.9 \\
\hline 6-Hydroxyluteolin 7-O-rhamnoside & 17.3 & 447.0929 & 447.0933 & - & $\mathrm{C}_{21} \mathrm{H}_{20} \mathrm{O}_{11}$ & -0.9 \\
\hline \multicolumn{7}{|l|}{ Dhydrochalcones $[\mathrm{M}-\mathrm{H}]^{-}$} \\
\hline Phloridzin & 17.21 & 435.1293 & 435.1297 & $272 / 188 / 178 / 166 / 150 / 112 / 92$ & $\mathrm{C}_{21} \mathrm{H}_{24} \mathrm{O}_{10}$ & -0.9 \\
\hline
\end{tabular}


Table S4. Phytochemical profile of homogenized at $100 \mathrm{MPa}$ lulo juice by high resolution LC-MS / MS

\begin{tabular}{|c|c|c|c|c|c|c|}
\hline \multicolumn{7}{|c|}{ Homogenized $100 \mathrm{MPa}$} \\
\hline Compound name & $\begin{array}{l}\text { RT } \\
(\min )\end{array}$ & $\begin{array}{l}\mathrm{M} / \mathrm{Z} \\
\text { experimental }\end{array}$ & Teoric mass & MS/MS fragments & $\begin{array}{l}\text { Molecular } \\
\text { Formula }\end{array}$ & $\begin{array}{l}\text { Error } \\
\text { (ppm) }\end{array}$ \\
\hline \multicolumn{7}{|l|}{ Hydroxycinnamic acids [M $-\mathrm{H}^{-}$} \\
\hline Cis-3-Caffeoylquinic acid & 12.93 & 353.0877 & 353.0878 & $190 / 84$ & $\mathrm{C}_{16} \mathrm{H}_{18} \mathrm{O}_{9}$ & -0.4 \\
\hline Trans-5-Caffeoylquinic acid & 12.93 & 353.0877 & 353.0878 & $354 / 353$ & $\mathrm{C}_{16} \mathrm{H}_{18} \mathrm{O}_{9}$ & -0.4 \\
\hline Cis-5-Caffeoylquinic acid & 12.93 & 353.0877 & 353.0878 & $190 / 84$ & $\mathrm{C}_{16} \mathrm{H}_{18} \mathrm{O}_{9}$ & -0.4 \\
\hline Trans-3-Caffeoylquinic acid & 12.93 & 353.0878 & 353.0877 & $190 / 84$ & $\mathrm{C}_{16} \mathrm{H}_{18} \mathrm{O}_{9}$ & -0.4 \\
\hline 1-Caffeoylquinic acid & 12.93 & 353.0878 & 353.0877 & $190 / 84$ & $\mathrm{C}_{16} \mathrm{H}_{18} \mathrm{O}_{9}$ & -0.4 \\
\hline 5-Caffeoylquinic acid & 12.93 & 353.0877 & 353.0878 & $190 / 84$ & $\mathrm{C}_{16} \mathrm{H}_{18} \mathrm{O}_{9}$ & -0.4 \\
\hline 3-Caffeoylquinic acid & 12.93 & 353.0878 & 353.0877 & $190 / 84$ & $\mathrm{C}_{16} \mathrm{H}_{18} \mathrm{O}_{9}$ & -0.4 \\
\hline 4-Caffeoylquinic acid & 12.93 & 353.0877 & 353.0878 & $190 / 84$ & $\mathrm{C}_{16} \mathrm{H}_{18} \mathrm{O}_{9}$ & -0.4 \\
\hline p-Coumaric acid 4 -O-glucoside & 12.95 & 325.093 & 325.0929 & $199 / 144 / 142 / / 116$ & $\mathrm{C}_{15} \mathrm{H}_{18} \mathrm{O}_{8}$ & 0.5 \\
\hline p-Coumaroyl glucose & 12.95 & 325.093 & 325.0929 & $199 / 144 / 142 / / 116$ & $\mathrm{C}_{15} \mathrm{H}_{18} \mathrm{O}_{8}$ & 0.5 \\
\hline Caffeic acid & 13.33 & 179.0351 & 179.035 & $134 / 133 / 108 / 88$ & $\mathrm{C}_{9} \mathrm{H}_{8} \mathrm{O}_{4}$ & 0.4 \\
\hline Trans-Caffeic acid & 13.33 & 179.0351 & 179.035 & $134 / 133 / 108 / 88$ & $\mathrm{C}_{9} \mathrm{H}_{8} \mathrm{O}_{4}$ & 0.4 \\
\hline Cis-Caffeic acid & 13.33 & 179.0351 & 179.035 & $134 / 133 / 108 / 88$ & $\mathrm{C}_{9} \mathrm{H}_{8} \mathrm{O}_{4}$ & 0.4 \\
\hline Ferulic acid 4-O-glucoside & 13.56 & 355.1035 & 355.103 & $174 / 159 / 131$ & $\mathrm{C}_{16} \mathrm{H}_{20} \mathrm{O}_{9}$ & -1.8 \\
\hline Feruloyl glucose & 13.56 & 355.1035 & 355.103 & $174 / 159 / 131$ & $\mathrm{C}_{16} \mathrm{H}_{20} \mathrm{O}_{9}$ & -1.3 \\
\hline 4-Hydroxybenzaldehyde & 14.27 & 121.0296 & 121.0295 & 91 & $\mathrm{C}_{7} \mathrm{H}_{6} \mathrm{O}_{2}$ & 0.6 \\
\hline p-Coumaroylquinic acid & 14.7 & 337.0929 & 337.0926 & $190 / 172 / 162 / 118 / 116 / 92$ & $\mathrm{C}_{15} \mathrm{H}_{18} \mathrm{O}_{8}$ & -0.9 \\
\hline 3-p-Coumaroylquinic acid & 14.7 & 337.0929 & 337.0926 & $189 / 172 / 162 / 118 / 116 / 92$ & $\mathrm{C}_{16} \mathrm{H}_{18} \mathrm{O}_{7}$ & -0.9 \\
\hline 4-p-Coumaroylquinic acid & 14.7 & 337.0929 & 337.0926 & $190 / 172 / 162 / 118 / 116 / 92$ & $\mathrm{C}_{16} \mathrm{H}_{18} \mathrm{O}_{8}$ & -0.9 \\
\hline 5-p-Coumaroylquinic acid & 14.7 & 337.0929 & 337.0926 & $190 / 172 / 162 / 118 / 116 / 92$ & $\mathrm{C}_{16} \mathrm{H}_{18} \mathrm{O}_{8}$ & -0.9 \\
\hline \multicolumn{7}{|l|}{ Flavonoids $[\mathrm{M}-\mathrm{H}]^{-}$} \\
\hline Kaempferol 3,7-O-diglucoside & 16.0 & 609.1466 & 609.1461 & $299 / 270$ & $\mathrm{C}_{27} \mathrm{H}_{30} \mathrm{O}_{16}$ & 0.8 \\
\hline Kaempferol 3-O-sophoroside & 16.0 & 609.1466 & 609.1461 & $299 / 270$ & $\mathrm{C}_{27} \mathrm{H}_{30} \mathrm{O}_{16}$ & 0.8 \\
\hline
\end{tabular}


Anexos

\begin{tabular}{|c|c|c|c|c|c|c|}
\hline Table $\times$ (continued) & & & & & & \\
\hline Compound name & $\begin{array}{c}\mathrm{RT} \\
(\mathrm{min})\end{array}$ & $\begin{array}{c}\mathrm{M} / \mathrm{Z} \\
\text { experimental }\end{array}$ & Teoric mass & MS/MS fragments & $\begin{array}{l}\text { Molecular } \\
\text { formula }\end{array}$ & $\begin{array}{l}\text { Error } \\
(\mathrm{ppm})\end{array}$ \\
\hline Quercetin 3-O-rutinoside & 16.0 & 609.1466 & 609.1461 & $299 / 270$ & $\mathrm{C}_{27} \mathrm{H}_{30} \mathrm{O}_{16}$ & 0.8 \\
\hline $\begin{array}{l}\text { Quercetin 3-O-galactoside 7-O- } \\
\text { rhamnoside }\end{array}$ & 16.0 & 609.1466 & 609.1461 & $299 / 270$ & $\mathrm{C}_{27} \mathrm{H}_{30} \mathrm{O}_{16}$ & 0.8 \\
\hline $\begin{array}{l}\text { Kaempferol 3-O-galactoside 7-0- } \\
\text { rhamnoside }\end{array}$ & 16.4 & 593.1512 & 593.1512 & $283 / 254$ & $\mathrm{C}_{27} \mathrm{H}_{30} \mathrm{O}_{15}$ & 0 \\
\hline \multicolumn{6}{|l|}{ Isorhamnetin 3-O-glucoside 7-0- } & 1.2 \\
\hline Isorhamnetin 3-O-rutinoside & 16.57 & 623.1625 & 623.1618 & $313 / 298 / 270$ & $\mathrm{C}_{28} \mathrm{H}_{32} \mathrm{O}_{16}$ & 1.2 \\
\hline Kaempferol 3-O-glucoside & 17.3 & 447.0933 & 447.0929 & - & $\mathrm{C}_{21} \mathrm{H}_{20} \mathrm{O}_{11}$ & -0.9 \\
\hline 3,7-Dimethylquercetin & 18.79 & 329.0666 & 329.0667 & - & $\mathrm{C}_{17} \mathrm{H}_{14} \mathrm{O}_{7}$ & -0.2 \\
\hline \multicolumn{7}{|l|}{ Phenolic acids $[\mathrm{M}-\mathrm{H}]^{-}$} \\
\hline 2-Hydroxybenzoic acid & 11.33 & 137.0245 & 137.0244 & $107 / 96 / 91$ & $\mathrm{C}_{7} \mathrm{H}_{6} \mathrm{O}_{3}$ & 0.5 \\
\hline 3-Hydroxybenzoic acid & 11.33 & 137.0245 & 137.0244 & $107 / 96 / 91$ & $\mathrm{C}_{7} \mathrm{H}_{6} \mathrm{O}_{3}$ & 0.5 \\
\hline 4-Hydroxybenzoic acid & 11.33 & 137.0245 & 137.0244 & $107 / 96 / 91$ & $\mathrm{C}_{7} \mathrm{H}_{6} \mathrm{O}_{3}$ & 0.5 \\
\hline 4-Hydroxybenzoic acid 4-O-glucoside & 12.82 & 299.0773 & 299.0772 & $136 / 92$ & $\mathrm{C}_{13} \mathrm{H}_{16} \mathrm{O}_{8}$ & 0.2 \\
\hline Benzoic acid & 14.27 & 121.0296 & 121.0295 & 91 & $\mathrm{C}_{7} \mathrm{H}_{6} \mathrm{O}_{2}$ & 0.6 \\
\hline \multicolumn{7}{|l|}{ Other phenolics $[\mathrm{M}-\mathrm{H}]^{-}$} \\
\hline Protocatechuic aldehyde & 11.33 & 137.0245 & 137.0244 & $107 / 96 / 91$ & $\mathrm{C}_{7} \mathrm{H}_{6} \mathrm{O}_{3}$ & 0.5 \\
\hline Sesamol & 11.33 & 137.0244 & 137.0245 & $107 / 96 / 91$ & $\mathrm{C}_{7} \mathrm{H}_{6} \mathrm{O}_{3}$ & 0.5 \\
\hline 4-Hydroxycoumarin & 12.88 & 161.0245 & 161.0244 & - & $\mathrm{C}_{9} \mathrm{H}_{6} \mathrm{O}_{3}$ & 0.5 \\
\hline Umbelliferone & 12.88 & 161.0245 & 161.0244 & 88 & $\mathrm{C}_{9} \mathrm{H}_{6} \mathrm{O}_{3}$ & 0.5 \\
\hline Coumarin & 12.94 & 145.0296 & 145.0295 & $116 / 115 / 87$ & $\mathrm{C}_{9} \mathrm{H}_{6} \mathrm{O}_{2}$ & 0.6 \\
\hline \multicolumn{7}{|l|}{ 3,4-Dihydroxyphenyl-2-oxypropanoic } \\
\hline acid & 13.33 & 179.035 & 179.0351 & $134 / 133 / 108 / 133 / 88$ & $\mathrm{C}_{9} \mathrm{H}_{8} \mathrm{O}_{4}$ & 0.4 \\
\hline 4-Hydroxybenzaldehyde & 14.06 & 121.0295 & 121.0296 & 91 & $\mathrm{C}_{7} \mathrm{H}_{6} \mathrm{O}_{2}$ & 0.7 \\
\hline 4-Hydroxyphenylacetic acid & 15.28 & 151.0401 & 151.0401 & - & $\mathrm{C}_{8} \mathrm{H}_{8} \mathrm{O}_{3}$ & 0.2 \\
\hline \multicolumn{7}{|l|}{ Flavanones $[\mathrm{M}-\mathrm{H}]^{-}$} \\
\hline Naringin 4-O-glucoside & 14.24 & 741.2254 & 741.2248 & 208/193/178 & $\mathrm{C}_{33} \mathrm{H}_{42} \mathrm{O}_{19}$ & 0.9 \\
\hline Neoeriocitrin & 16.27 & 595.1674 & 595.1668 & - & $\mathrm{C}_{27} \mathrm{H}_{32} \mathrm{O}_{15}$ & 0.9 \\
\hline
\end{tabular}


Table x (continued)

\begin{tabular}{|c|c|c|c|c|c|c|}
\hline Compound name & $\begin{array}{c}\mathrm{RT} \\
(\mathrm{min})\end{array}$ & $\begin{array}{c}M / Z \\
\text { experimental }\end{array}$ & Teoric mass & MS/MS fragments & $\begin{array}{c}\text { Molecular } \\
\text { formula }\end{array}$ & $\begin{array}{l}\text { Error } \\
\text { (ppm) }\end{array}$ \\
\hline Neohesperidin & 17.01 & 609.1831 & 609.1825 & 300 & $\mathrm{C}_{28} \mathrm{H}_{34} \mathrm{O}_{15}$ & 0.9 \\
\hline Hesperidin & 17.01 & 609.1831 & 609.1825 & 300 & $\mathrm{C}_{28} \mathrm{H}_{34} \mathrm{O}_{15}$ & 0.9 \\
\hline Hesperetin & 17.03 & 301.0716 & 301.0718 & - & $\mathrm{C}_{16} \mathrm{H}_{14} \mathrm{O}_{6}$ & -0.5 \\
\hline \multicolumn{7}{|l|}{ Flavones $[\mathrm{M}-\mathrm{H}]^{-}$} \\
\hline Apigenin 6,8-di-C-glucoside & 16.4 & 593.1512 & 593.1512 & $283 / 254$ & $\mathrm{C}_{27} \mathrm{H}_{30} \mathrm{O}_{15}$ & 0 \\
\hline Luteolin 7-O-rutinoside & 16.4 & 593.1512 & 593.1512 & $283 / 254$ & $\mathrm{C}_{27} \mathrm{H}_{30} \mathrm{O}_{15}$ & 0 \\
\hline Luteolin 4-O-glucoside & 17.3 & 447.0933 & 447.0929 & - & $\mathrm{C}_{21} \mathrm{H}_{20} \mathrm{O}_{11}$ & -0.9 \\
\hline Luteolin 6-C-glucoside & 17.3 & 447.0933 & 447.0929 & - & $\mathrm{C}_{21} \mathrm{H}_{20} \mathrm{O}_{11}$ & -0.9 \\
\hline Luteolin 7-O-glucoside & 17.3 & 447.0929 & 447.0933 & - & $\mathrm{C}_{21} \mathrm{H}_{20} \mathrm{O}_{11}$ & -0.9 \\
\hline Luteolin 8-C-glucoside & 17.3 & 447.0929 & 447.0933 & - & $\mathrm{C}_{21} \mathrm{H}_{20} \mathrm{O}_{11}$ & -0.9 \\
\hline \multicolumn{7}{|l|}{ Dhydrochalcones $[\mathrm{M}-\mathrm{H}]^{-}$} \\
\hline Phloridzin & 17.42 & 435.1297 & 435.1297 & $178 / 166 / 155 / 122 / 100 / 84$ & $\mathrm{C}_{21} \mathrm{H}_{24} \mathrm{O}_{10}$ & 0 \\
\hline
\end{tabular}


Anexos

Table S5. Phytochemical profile of homogenized at $150 \mathrm{MPa}$ lulo juice by high resolution LC-MS/MS

\begin{tabular}{|c|c|c|c|c|c|c|}
\hline \multicolumn{7}{|c|}{ Homogenized $150 \mathrm{MPa}$} \\
\hline Compound name & $\begin{array}{l}\text { RT } \\
(\min )\end{array}$ & $\begin{array}{l}\mathrm{M} / \mathrm{Z} \\
\text { experimental }\end{array}$ & $\begin{array}{l}\text { Teoric } \\
\text { mass }\end{array}$ & MS/MS fragments & $\begin{array}{l}\text { Molecular } \\
\text { Formula }\end{array}$ & $\begin{array}{l}\text { Error } \\
\text { (ppm) }\end{array}$ \\
\hline \multicolumn{7}{|c|}{ Hydroxycinnamic acids [M - $\left.{ }^{-}\right]^{-}$} \\
\hline 3-Caffeoylquinic acid & 12.9 & 353.0875 & 353.0878 & $190 / 84$ & $\mathrm{C}_{16} \mathrm{H}_{18} \mathrm{O}_{9}$ & -0.9 \\
\hline Cis-3-Caffeoylquinic acid & 12.9 & 353.0875 & 353.0878 & $190 / 84$ & $\mathrm{C}_{16} \mathrm{H}_{18} \mathrm{O}_{9}$ & -0.9 \\
\hline Trans-5-Caffeoylquinic acid & 12.9 & 353.0875 & 353.0878 & $190 / 84$ & $\mathrm{C}_{16} \mathrm{H}_{18} \mathrm{O}_{9}$ & -0.9 \\
\hline Cis-5-Caffeoylquinic acid & 12.9 & 353.0875 & 353.0878 & $190 / 84$ & $\mathrm{C}_{16} \mathrm{H}_{18} \mathrm{O}_{9}$ & -0.9 \\
\hline 4-Caffeoylquinic acid & 12.9 & 353.0875 & 353.0878 & $190 / 84$ & $\mathrm{C}_{16} \mathrm{H}_{18} \mathrm{O}_{9}$ & -0.9 \\
\hline 5-Caffeoylquinic acid & 12.9 & 353.0875 & 353.0878 & $190 / 84$ & $\mathrm{C}_{16} \mathrm{H}_{18} \mathrm{O}_{9}$ & -0.9 \\
\hline Trans-3-Caffeoylquinic acid & 12.9 & 353.0875 & 353.0878 & $190 / 84$ & $\mathrm{C}_{16} \mathrm{H}_{18} \mathrm{O}_{9}$ & -0.9 \\
\hline 1-Caffeoylquinic acid & 12.9 & 353.0875 & 353.0878 & $190 / 84$ & $\mathrm{C}_{16} \mathrm{H}_{18} \mathrm{O}_{9}$ & -0.9 \\
\hline Caffeic acid & 13.28 & 179.0351 & 179.035 & $134 / 133 / 105 / 90 / 88$ & $\mathrm{C}_{9} \mathrm{H}_{8} \mathrm{O}_{4}$ & 0.9 \\
\hline Trans-Caffeic acid & 13.28 & 179.0351 & 179.035 & $134 / 133 / 105 / 90 / 88$ & $\mathrm{C}_{9} \mathrm{H}_{8} \mathrm{O}_{4}$ & 0.9 \\
\hline Cis-Caffeic acid & 13.28 & 179.0351 & 179.035 & $134 / 133 / 105 / 90 / 88$ & $\mathrm{C}_{9} \mathrm{H}_{8} \mathrm{O}_{4}$ & 0.9 \\
\hline Ferulic acid 4-O-glucoside & 13.52 & 355.1031 & 355.1035 & $174 / 159 / 131$ & $\mathrm{C}_{16} \mathrm{H}_{20} \mathrm{O}_{9}$ & -0.9 \\
\hline Feruloyl glucose & 13.52 & 355.1031 & 355.1035 & $174 / 159 / 131$ & $\mathrm{C}_{16} \mathrm{H}_{20} \mathrm{O}_{9}$ & -0.9 \\
\hline p-Coumaroylquinic acid & 14.64 & 337.0928 & 337.0929 & - & $\mathrm{C}_{16} \mathrm{H}_{18} \mathrm{O}_{8}$ & -0.2 \\
\hline 3-p-Coumaroylquinic acid & 14.64 & 337.0928 & 337.0929 & - & $\mathrm{C}_{16} \mathrm{H}_{18} \mathrm{O}_{8}$ & -0.2 \\
\hline 4-p-Coumaroylquinic acid & 14.64 & 337.0928 & 337.0929 & - & $\mathrm{C}_{16} \mathrm{H}_{18} \mathrm{O}_{8}$ & -0.2 \\
\hline 5-p-Coumaroylquinic acid & 14.64 & 337.0928 & 337.0929 & - & $\mathrm{C}_{16} \mathrm{H}_{18} \mathrm{O}_{8}$ & -0.2 \\
\hline 5-Feruloylquinic acid & 15.02 & 367.1035 & 367.1035 & $334 / 274 / 190 / 172 / 154 / 133 / 92$ & $\mathrm{C}_{17} \mathrm{H}_{20} \mathrm{O}_{9}$ & 0.1 \\
\hline 4-Feruloylquinic acid & 15.02 & 367.1035 & 367.1035 & $334 / 274 / 190 / 172 / 154 / 133 / 92$ & $\mathrm{C}_{17} \mathrm{H}_{20} \mathrm{O}_{9}$ & 0.1 \\
\hline 3-Feruloylquinic acid & 15.02 & 367.1035 & 367.1035 & $334 / 274 / 190 / 172 / 154 / 133 / 92$ & $\mathrm{C}_{17} \mathrm{H}_{20} \mathrm{O}_{9}$ & 0.1 \\
\hline
\end{tabular}




\begin{tabular}{|c|c|c|c|c|c|c|}
\hline Table $\times$ (continued) & & & & & & \\
\hline Compound name & $\begin{array}{c}\mathrm{RT} \\
(\mathrm{min})\end{array}$ & $\begin{array}{c}\mathrm{M} / \mathrm{Z} \\
\text { experimental }\end{array}$ & $\begin{array}{l}\text { Teoric } \\
\text { mass }\end{array}$ & MS/MS fragments & $\begin{array}{c}\text { Molecular } \\
\text { formula }\end{array}$ & $\begin{array}{l}\text { Error } \\
\text { (ppm) }\end{array}$ \\
\hline \multicolumn{7}{|l|}{ Flavonoids [M - H] ${ }^{-}$} \\
\hline Kaempferol 3,7-O-diglucoside & 15.96 & 609.1469 & 609.1461 & $270 / 299$ & $\mathrm{C}_{27} \mathrm{H}_{30} \mathrm{O}_{16}$ & 1.2 \\
\hline \multicolumn{7}{|l|}{ Quercetin 3-O-rhamnosyl- } \\
\hline galactoside & 15.96 & 609.1469 & 609.1461 & $270 / 299$ & $\mathrm{C}_{27} \mathrm{H}_{30} \mathrm{O}_{16}$ & 1.2 \\
\hline \multicolumn{7}{|l|}{ Quercetin 3-O-galactoside 7-O- } \\
\hline rhamnoside & 15.96 & 609.1469 & 609.1461 & $270 / 299$ & $\mathrm{C}_{27} \mathrm{H}_{30} \mathrm{O}_{16}$ & 1.2 \\
\hline Kaempferol 3-O-sophoroside & 15.96 & 609.1469 & 609.1461 & $270 / 299$ & $\mathrm{C}_{27} \mathrm{H}_{30} \mathrm{O}_{16}$ & 1.2 \\
\hline Quercetin 3-O-rutinoside & 15.8 & 609.1467 & 609.1461 & $299 / 270$ & $\mathrm{C}_{27} \mathrm{H}_{30} \mathrm{O}_{16}$ & 1.0 \\
\hline Kaempferol 3-O-galactoside & 17.48 & 447.0934 & 447.0933 & $226 / 254 / 283$ & $\mathrm{C}_{21} \mathrm{H}_{20} \mathrm{O}_{11}$ & 0.4 \\
\hline Kaempferol 3-O-glucoside & 17.48 & 447.0933 & 447.0934 & $226 / 254 / 283$ & $\mathrm{C}_{21} \mathrm{H}_{20} \mathrm{O}_{11}$ & 0.4 \\
\hline Kaempferol 7-O-glucoside & 17.48 & 447.0934 & 447.0933 & $226 / 254 / 283$ & $\mathrm{C}_{21} \mathrm{H}_{20} \mathrm{O}_{11}$ & 0.4 \\
\hline Quercetin 3-O-rhamnoside & 17.48 & 447.0934 & 447.0933 & $226 / 254 / 283$ & $\mathrm{C}_{21} \mathrm{H}_{20} \mathrm{O}_{11}$ & 0.4 \\
\hline \multicolumn{7}{|l|}{ Phenolic acids $[\mathrm{M}-\mathrm{H}]^{-}$} \\
\hline 2-Hydroxybenzoic acid & 11.36 & 137.0245 & 137.0244 & $107 / 90$ & $\mathrm{C}_{7} \mathrm{H}_{6} \mathrm{O}_{3}$ & 1 \\
\hline 3-Hydroxybenzoic acid & 11.36 & 137.0245 & 137.0244 & $107 / 90$ & $\mathrm{C}_{7} \mathrm{H}_{6} \mathrm{O}_{3}$ & 1 \\
\hline 4-Hydroxybenzoic acid & 11.36 & 137.0245 & 137.0244 & $107 / 90$ & $\mathrm{C}_{7} \mathrm{H}_{6} \mathrm{O}_{3}$ & 1 \\
\hline \multicolumn{7}{|l|}{ 4-Hydroxybenzoic acid 4-O- } \\
\hline glucoside & 12.8 & 299.0774 & 299.0772 & $136 / 92$ & $\mathrm{C}_{13} \mathrm{H}_{16} \mathrm{O}_{8}$ & 0.4 \\
\hline Benzoic acid & 14.22 & 121.0296 & 121.0295 & - & $\mathrm{C}_{7} \mathrm{H}_{6} \mathrm{O}_{2}$ & 0.9 \\
\hline \multicolumn{7}{|l|}{ Other phenolics $[\mathrm{M}-\mathrm{H}]^{-}$} \\
\hline Sesamol & 11.36 & 137.0245 & 137.0244 & $107 / 90$ & $\mathrm{C}_{7} \mathrm{H}_{6} \mathrm{O}_{3}$ & 1 \\
\hline 4-Hydroxycoumarin & 12.85 & 161.0245 & 161.0244 & - & $\mathrm{C}_{9} \mathrm{H}_{6} \mathrm{O}_{3}$ & 0.3 \\
\hline \multicolumn{7}{|l|}{ 3,4-Dihydroxyphenyl-2- } \\
\hline oxypropanoic acid & 13.28 & 179.0351 & 179.035 & $90 / 105 / 132 / 133 / 134$ & $\mathrm{C}_{9} \mathrm{H}_{8} \mathrm{O}_{4}$ & 0.9 \\
\hline 4-Hydroxybenzaldehyde & 14.22 & 121.0296 & 121.0295 & $154 / 144 / 118 / 116 / 106 / 92$ & $\mathrm{C}_{7} \mathrm{H}_{6} \mathrm{O}_{2}$ & 0.9 \\
\hline Homovanillyl alcohol & 18.27 & 167.0715 & 167.0714 & & $\mathrm{C}_{9} \mathrm{H}_{12} \mathrm{O}_{3}$ & 0.6 \\
\hline Chalconaringenin & 18.59 & 271.0614 & 271.0612 & $154 / 144 / 118 / 116 / 106 / 92$ & $\mathrm{C}_{15} \mathrm{H}_{12} \mathrm{O}_{5}$ & 0.9 \\
\hline Sitostanyl ferulate & 20.52 & 607.4364 & 607.4368 & - & $\mathrm{C}_{39} \mathrm{H}_{60} \mathrm{O}_{5}$ & -0.6 \\
\hline
\end{tabular}


Anexos

\begin{tabular}{|c|c|c|c|c|c|c|}
\hline Table $\times$ (continued) & & & & & & \\
\hline Compound name & $\begin{array}{c}\mathrm{RT} \\
(\min )\end{array}$ & $\begin{array}{c}\mathrm{M} / \mathrm{Z} \\
\text { experimental }\end{array}$ & $\begin{array}{l}\text { Teoric } \\
\text { mass }\end{array}$ & MS/MS fragments & $\begin{array}{l}\text { Molecular } \\
\text { formula }\end{array}$ & $\begin{array}{l}\text { Error } \\
\text { (ppm) }\end{array}$ \\
\hline Flavanones $[\mathrm{M}-\mathrm{H}]^{-}$ & & & & & & \\
\hline Protocatechuic aldehyde & 11.36 & 137.0245 & 137.0244 & $107 / 90$ & $\mathrm{C} 7 \mathrm{H} 6 \mathrm{O} 3$ & 1 \\
\hline Narirutin 4-O-glucoside & 14.19 & 741.2249 & 741.2248 & 208/193 & $\mathrm{C}_{33} \mathrm{H}_{42} \mathrm{O}_{19}$ & 0.2 \\
\hline Narirutin & 16.84 & 579.1725 & 579.1719 & $270 / 150$ & $\mathrm{C}_{27} \mathrm{H}_{32} \mathrm{O}_{14}$ & 0.9 \\
\hline Naringin & 16.84 & 579.1725 & 579.1719 & $270 / 150$ & $\mathrm{C}_{27} \mathrm{H}_{32} \mathrm{O}_{14}$ & 0.9 \\
\hline Naringenin & 18.59 & 271.0614 & 271.0612 & $144 / 118 / 116 / 106 / 92$ & $\mathrm{C}_{15} \mathrm{H}_{12} \mathrm{O}_{5}$ & 0.9 \\
\hline Hesperetin & 16.98 & 301.0721 & 301.0718 & - & $\mathrm{C}_{16} \mathrm{H}_{14} \mathrm{O}_{6}$ & 1 \\
\hline Naringenin 7-0-glucoside & 17.56 & 433.1142 & 433.114 & $270 / 226 / 186 / 176 / 150 / 118 / 106$ & $\mathrm{C}_{21} \mathrm{H}_{22} \mathrm{O}_{10}$ & 0.4 \\
\hline Engeletin & 17.56 & 433.1142 & 433.114 & 270/226/186/176/150/118/106 & $\mathrm{C}_{21} \mathrm{H}_{22} \mathrm{O}_{10}$ & 0.4 \\
\hline Butein & 18.59 & 271.0614 & 271.0612 & $154 / 144 / 118 / 116 / 106 / 92$ & $\mathrm{C}_{15} \mathrm{H}_{12} \mathrm{O}_{5}$ & 0.9 \\
\hline Flavones $[\mathrm{M}-\mathrm{H}]^{-}$ & & & & & & \\
\hline Luteolin 4-O-glucoside & 17.48 & 447.0934 & 447.0933 & $283 / 254 / 226$ & $\mathrm{C}_{21} \mathrm{H}_{20} \mathrm{O}_{11}$ & 0.4 \\
\hline Luteolin 6-C-glucoside & 17.48 & 447.0934 & 447.0933 & $283 / 254 / 226$ & $\mathrm{C}_{21} \mathrm{H}_{20} \mathrm{O}_{11}$ & 0.4 \\
\hline Luteolin 7-0-glucoside & 17.48 & 447.0933 & 447.0934 & $283 / 254 / 226$ & $\mathrm{C}_{21} \mathrm{H}_{20} \mathrm{O}_{11}$ & 0.4 \\
\hline Luteolin 8-C-glucoside & 17.48 & 447.0934 & 447.0933 & $283 / 254 / 226$ & $\mathrm{C}_{21} \mathrm{H}_{20} \mathrm{O}_{11}$ & 0.4 \\
\hline 6-Hydroxyluteolin 7-0-rhamnoside & 17.48 & 447.0934 & 447.0933 & $283 / 254 / 226$ & $\mathrm{C}_{21} \mathrm{H}_{20} \mathrm{O}_{11}$ & 0.4 \\
\hline Flavonols $[\mathrm{M}-\mathrm{H}]^{-}$ & & & & & & \\
\hline $\begin{array}{l}\text { 5,4-Dihydroxy-3,3-dimethoxy-6:7- } \\
\text { methylenedioxyflavone }\end{array}$ & 19.26 & 357.062 & 357.0616 & $182 / 179 / 120 / 125 / 112 / 120$ & $\mathrm{C}_{18} \mathrm{H}_{14} \mathrm{O}_{8}$ & 1.1 \\
\hline Anthocynins $[\mathrm{M}-\mathrm{H}]^{-}$ & & & & & & \\
\hline Malvidin 3-0-(6-acetyl-galactoside & 2.68 & 534.1387 & 534.1379 & $190 / 110 / 86$ & $\mathrm{C}_{25} \mathrm{H}_{27} \mathrm{O}_{13}$ & 1.5 \\
\hline Malvidin 3-0-(6-acetyl-glucoside) & 2.68 & 534.1387 & 534.1379 & $190 / 110 / 86$ & $\mathrm{C}_{25} \mathrm{H}_{27} \mathrm{O}_{13}$ & 1.5 \\
\hline Cyanidin 3-O-laminaribioside & 15.96 & 610.1516 & 610.1539 & $300 / 271$ & $\mathrm{C}_{27} \mathrm{H}_{31} \mathrm{O}_{16}$ & -3.8 \\
\hline Cyanidin 3-O-sophoroside & 15.96 & 610.1539 & 610.1516 & $300 / 271$ & $\mathrm{C}_{27} \mathrm{H}_{31} \mathrm{O}_{16}$ & -3.8 \\
\hline Delphinidin 3-O-rutinoside & 15.96 & 610.1516 & 610.1539 & $300 / 271$ & $\mathrm{C}_{27} \mathrm{H}_{31} \mathrm{O}_{16}$ & -3.8 \\
\hline Dhydrochalcones $[\mathrm{M}-\mathrm{H}]^{-}$ & & & & & & \\
\hline Phloridzin & 17.39 & 435.1294 & 435.1297 & $272 / 254 / 178 / 166 / 150 / 188$ & $\mathrm{C}_{21} \mathrm{H}_{24} \mathrm{O}_{10}$ & -0.2 \\
\hline
\end{tabular}


Table S6. Polyamines identified in lulo fruit and its non-homogenized and homogenized juice at different homogenization pressures by high performance LC-MS/MS.

\begin{tabular}{|c|c|c|c|c|c|}
\hline Compound & Sample & Rt (Min) & $\begin{array}{c}{[\mathrm{M}-\mathrm{H}]-/[\mathrm{M}-} \\
\mathrm{H}]+\end{array}$ & $\begin{array}{l}\mathrm{MS}^{2} \text { fragments } \\
\mathrm{m} / \mathrm{z}\end{array}$ & Molecular Formula \\
\hline $\mathrm{N}, \mathrm{N}^{\prime}$-bis(dihydrocaffeoyl) spermine & & 13.12 & $472 / 474$ & $350(40), 308(40)$ & $\mathrm{C}_{25} \mathrm{H}_{35} \mathrm{~N}_{3} \mathrm{O}_{6}$ \\
\hline $\begin{array}{l}\mathrm{N}, \mathrm{N}^{\prime} \mathrm{N} \text {-tris(dihydrocaffeoyl) } \\
\text { spermine }\end{array}$ & & 16.4 & $637 / 638$ & $514(25), 472(30)$ & $\mathrm{C}_{34} \mathrm{H}_{43} \mathrm{~N}_{3} \mathrm{O}_{9}$ \\
\hline $\begin{array}{l}\mathrm{N}, \mathrm{N}^{\prime} \text {-bis(dihydrocaffeoyl) spermine } \\
\text { hexoside }\end{array}$ & $\begin{array}{l}\text { LF, NHJ, H50J, } \\
\text { H100J, H150J }\end{array}$ & 16.6 & $653 / 653$ & - & $\mathrm{C}_{31} \mathrm{H}_{47} \mathrm{~N}_{3} \mathrm{O}_{12}$ \\
\hline $\begin{array}{l}\mathrm{N}, \mathrm{N}, \mathrm{N}^{\prime} \text {-tris(dihydrocaffeoyl) } \\
\text { spermine hexoside }\end{array}$ & & 17.8 & $817 / 818$ & - & $\mathrm{C}_{0} \mathrm{H}_{55} \mathrm{~N}_{3} \mathrm{O}_{15}$ \\
\hline $\begin{array}{l}\mathrm{N}, \mathrm{N}^{\prime} \text {-bis(dihydrocaffeoyl) spermine } \\
\text { dihexoside }\end{array}$ & & 18.9 & $833 / 834$ & - & $\mathrm{C}_{37} \mathrm{H}_{59} \mathrm{~N}_{3} \mathrm{O}_{18}$ \\
\hline
\end{tabular}

